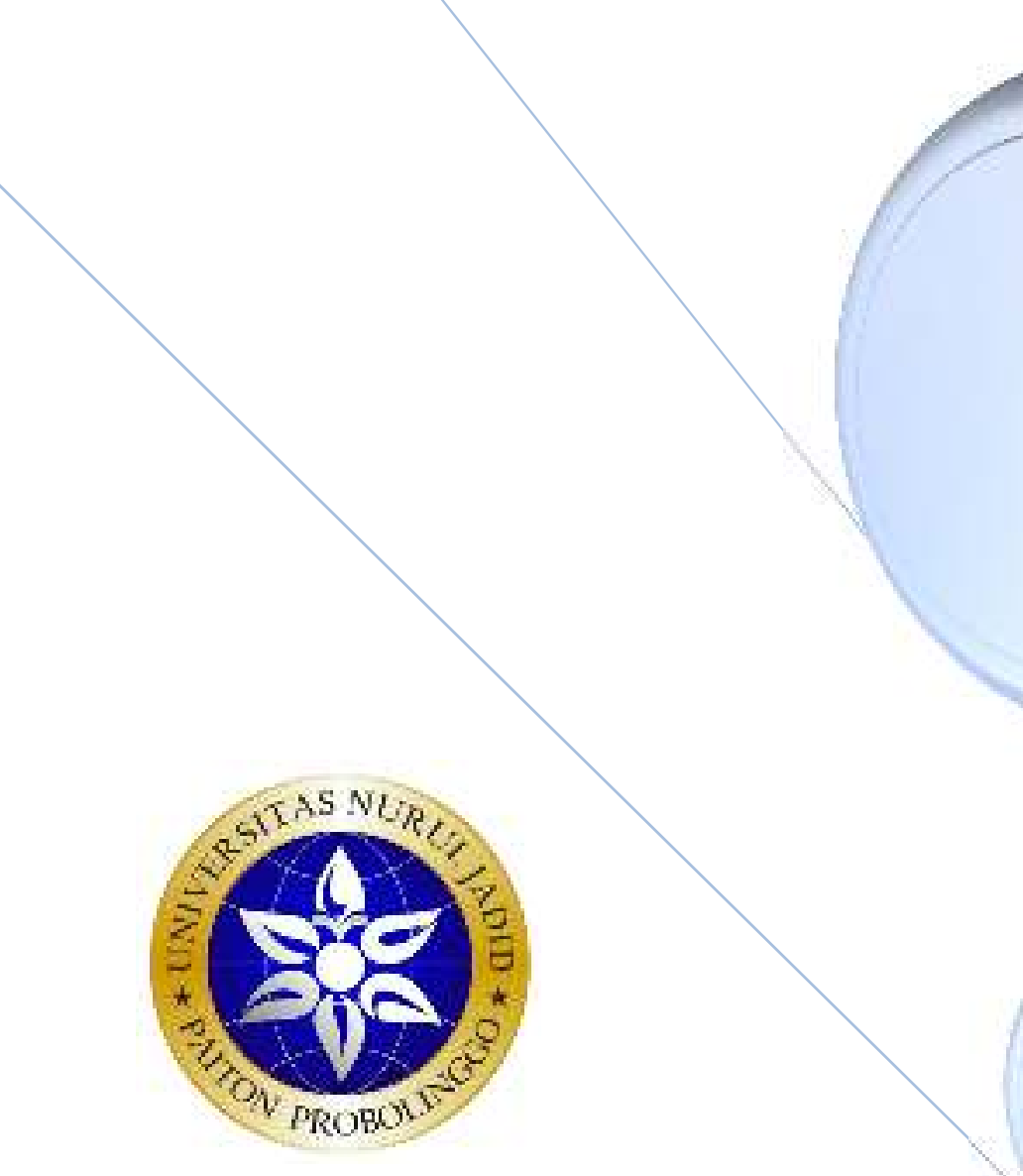

BUKU AJAR ANATOMI DAN FISIOLOGI SISTEM TUBUH

BAGI MAHASISWA KEPERAWATAN MEDIKAL BEDAH

OLEH:

SETIYO ADI NUGROHO. Ns., M.Kep. 


\section{KATA PENGANTAR}

Puji syukur kehadirat Allah SWT atas rahmat dan hidayah-Nya kami dapat menyelesaikan Buku ajar kami yang berjudul "BUKU AJAR ANATOMI DAN FISIOLOGI SISTEM TUBUH BAGI MAHASISWA KEPERAWATAN MEDIKAL BEDAH" untuk memenuh Buku ini memberikan pandangan singkat mengenai Anatomi dan Fisiologi Sistem endokrin, kardiologi, muskuluskletal, pencernaan, perkemihan, pernafasan dan persyarafan.

Penulis menyadari bahwa dalam proses penulisan buku ini masih jauh dari kesempurnaan baik materi maupun cara penulisannya. Namun demikian, penulis telah berupaya dengan segala kemampuan dan pengetahuan yang dimiliki sehingga buku ini dapat selesai dengan baik. Oleh karena itu, kritik dan saran yang membangun sangat berarti bagi kami. Besar harapan kami semoga makalah ini dapat menambah pengetahuan dan wawasan serta memberi manfaat bagi pembaca. Aamiin.

Probolinggo, Agustus 2021

Setiyo Adi Nugroho.Ns. M.Kep 


\section{DAFTAR ISI}

\section{Kata Pengantar}

\section{Daftar Isi}

1. Anatomi dn Fisiologi Sistem Endokrin .......................................................... 1

2. Anatomi dn Fisiologi Sistem Kardiologi .............................................................. 44

3. Anatomi dn Fisiologi Sistem Muskuluskletal ................................................... 57

4. Anatomi dn Fisiologi Sistem Pencernaan.......................................................... 71

5. Anatomi dn Fisiologi Sistem Perkemihan ............................................................. 99

6. Anatomi dn Fisiologi Sistem Pernafasan.......................................................... 110

7. Anatomi dn Fisiologi Sistem Persyarafan ....................................................... 129 DAFTAR PUSTAKA 
Sistem endokrin merupakan sistem yang unik karena terdiri dari kelompok berbagai kelenjar atau jaringan yang tersebar di seluruh tubuh. Kelenjar tubuh memiliki fungsi baik eksokrin atau endokrin. Kelenjar eksokrin, termasuk kelenjar keringat dan kelenjar lakrimal, bertanggung jawab untuk mengeluarkan zat langsung ke saluran yang mengarah ke daerah sasaran. Endokrin Istilah (endo-dalam, Crin-mensekresikan) ini menunjukkan bahwa sekresi dibentuk oleh kelenjar secara langsung masuk ke darah atau limfa sirkulasi dan perjalanan ke jaringan target, dan bukan diangkut melalui tuba atau duktus. Sekresi ini, disebut hormon, yang merupakan bahan kimia yang memicu atau mengontrol aktivitas organ, sistem, atau kelenjar lain di bagian tubuh lain (White, Duncan, \& Baumle, 2013). Hormon juga memainkan peran penting dalam mengatur proses homeostasis seperti: metabolism, tumbang, keseimbangan cairan dan elektrolit, proses reproduksi, dan siklus bangun dan tidur (Timby \& Smith, 2010).

Umumnya, hormon ini diproduksi oleh kelenjar endokrin, tetapi beberapa juga diproduksi oleh jaringan lain. mukosa Gastrointestinal (GI) menghasilkan hormon (misalnya, gastrin, enterogastrone, secretin, cholecystokinin) yang penting dalam proses pencernaan; ginjal menghasilkan erythropoietin, suatu hormon yang merangsang sumsum tulang untuk memproduksi sel darah merah; dan sel-sel darah putih memproduksi sitokin (protein menyerupai hormon) yang aktif berpartisipasi dalam respon inflamasi dan kekebalan tubuh. Sistem kekebalan tubuh dan sistem saraf memiliki hubungan yang unik dengan sistem endokrin. Porth \& Matfin, (2009) menyampaikan bahan kimia seperti neurotransmitter (misalnya, epinefrin) yang dirilis oleh Sistem saraf, juga dapat berfungsi sebagai hormon bila diperlukan. Sistem kekebalan tubuh merespon pengenalan asing agen dengan cara pembawa pesan kimiawi (sitokin), yang berupa protein menyerupai hormon, dan diatur adrenal kortikosteroid hormon (Smeltzer, Hinkle, Bare, \& Cheever, 2010)

Saraf dan sistem endokrin bertindak bersama-sama untuk mengkoordinasikan fungsi semua sistem tubuh. Ingat bahwa sistem saraf bekerja melalui impuls saraf (potensial aksi) yang dilakukan di sepanjang akson neuron. Pada sinaps, impuls saraf memicu pelepasan mediator (utusan) molekul yang disebut neurotransmitter. Sistem endokrin juga mengontrol aktivitas tubuh dengan melepaskan mediator, yang disebut hormon, tetapi alat kontrol dari dua sistem yang sangat berbeda. Tanggapan dari sistem endokrin sering lebih lambat daripada respon sistem saraf; meskipun beberapa hormon bertindak dalam hitungan detik, sebagian besar berlangsung beberapa menit atau lebih untuk menghasilkan sebuah respon. Efek dari sistem aktivasi saraf umumnya lebih singkat dibandingkan sistem endokrin. Sistem saraf bekerja pada otot-otot dan kelenjar tertentu. Pengaruh sistem endokrin jauh lebih luas; membantu mengatur hampir semua jenis sel tubuh. Kami juga akan memiliki beberapa kesempatan untuk melihat bagaimana sistem saraf dan endokrin berfungsi bersama-sama sebagai interlocking "supersystem." Misalnya, bagian-bagian tertentu dari sistem saraf merangsang atau menghambat pelepasan hormon oleh sistem endokrin (Tortora \& Derrickson, 2014). 


\begin{tabular}{|c|c|c|}
\hline CHAMACTERISTIE & NERVDUS SYSTEM & ENDDCIUNE SYSTERA \\
\hline Madivine maleniles & 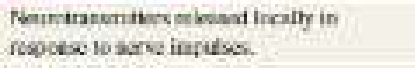 & 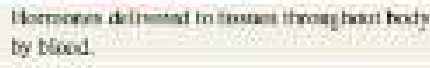 \\
\hline Ste of mediatior artien & 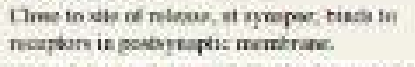 & 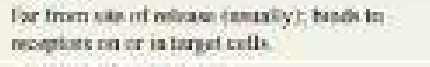 \\
\hline Types of taeget cels & 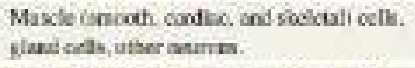 & Cafl throghoat boty. \\
\hline Times to onset of sodion & 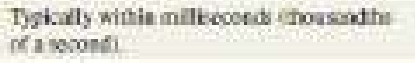 & Soconds an hoars or doys. \\
\hline Duration of action. & Gonondy triefer inalivesendh: & 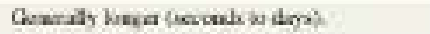 \\
\hline
\end{tabular}

Sebagian besar hormon kelenjar endokrin dikontrol oleh kelenjar hipofisis dan mekanisme feedback. Tingkat hormon dalam darah diatur oleh mekanisme homeostasis disebut negatif feedback. Jika kadar hormone dalam darah di bawah normal, negatif feedback merespon kelenjar endokrin tertentu untuk menghasilkan lebih banyak hormon, yang ketika naik ke tingkat yang normal menyebabkan penurunan produksi Mekanisme Positive feedback juga terjadi dalam sistem endokrin. Dalam Positive feedback, kenaikan tingkat satu hormon akan memicu pelepasan hormon lain. Hal ini terjadi selama siklus menstruasi wanita.(White et al., 2013).

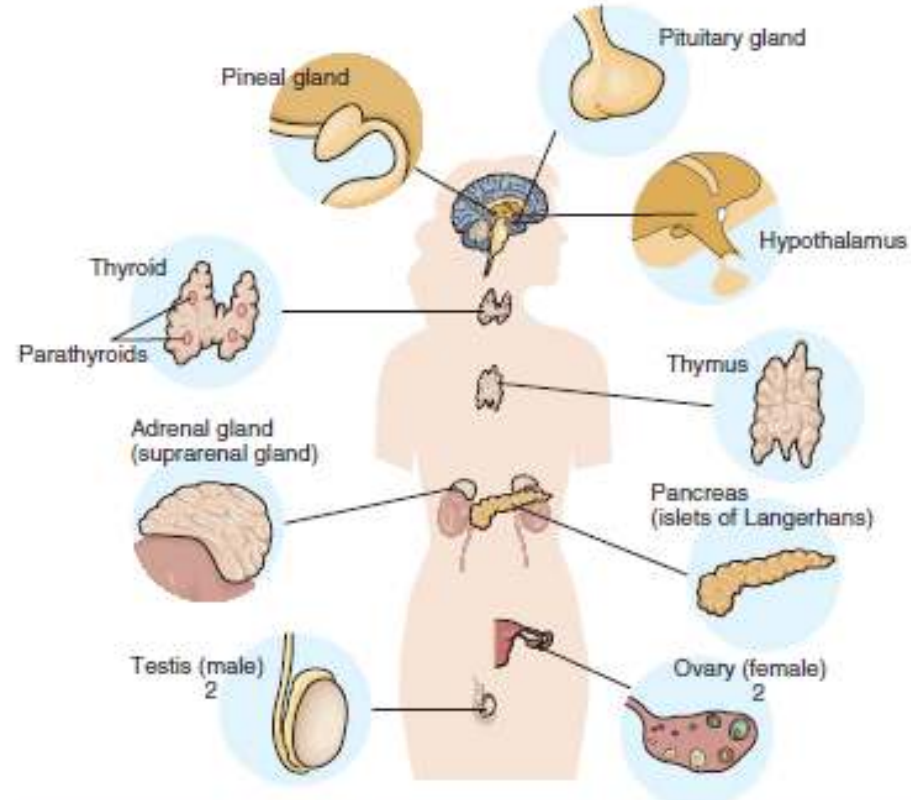

FIGURE 29-1 Structures of the endocrine system.
Sistem endokrin terdiri dari hipofisis, hipotalamus, tiroid, paratiroid, pankreas, adrenal, timus, ovarium, dan testis. Sistem endokrin tidak semudah seperti sistem tubuh yang lain. Ketika membahas ketidakseimbangan sistem endokrin, seringkali adanya variasi yaitu meningkat atau menurun (misalnya, hipertiroidisme dengan hipotiroidisme) (Daniels \& Nicoll, 2012).

sebagian besar hormon yang diperlukan dalam jumlah yang sangat kecil, tingkat sirkulasi biasanya rendah. Kelenjar endokrin termasuk hipofisis, tiroid, paratiroid, adrenal, dan kelenjar pineal. Selain itu, beberapa organ dan jaringan tidak eksklusif diklasifikasikan sebagai kelenjar endokrin tapi mengandung sel-sel yang mengeluarkan hormon. ini termasuk hipotalamus, timus, pankreas, ovarium, testis, ginjal, lambung, jantung, usus kecil, kulit, jantung, jaringan adiposa, dan plasenta. Secara bersama-sama, semua kelenjar endokrin dan Sel-sel yang mensekresi hormon merupakan sistem endokrin (Tortora \& Derrickson, 2014). 


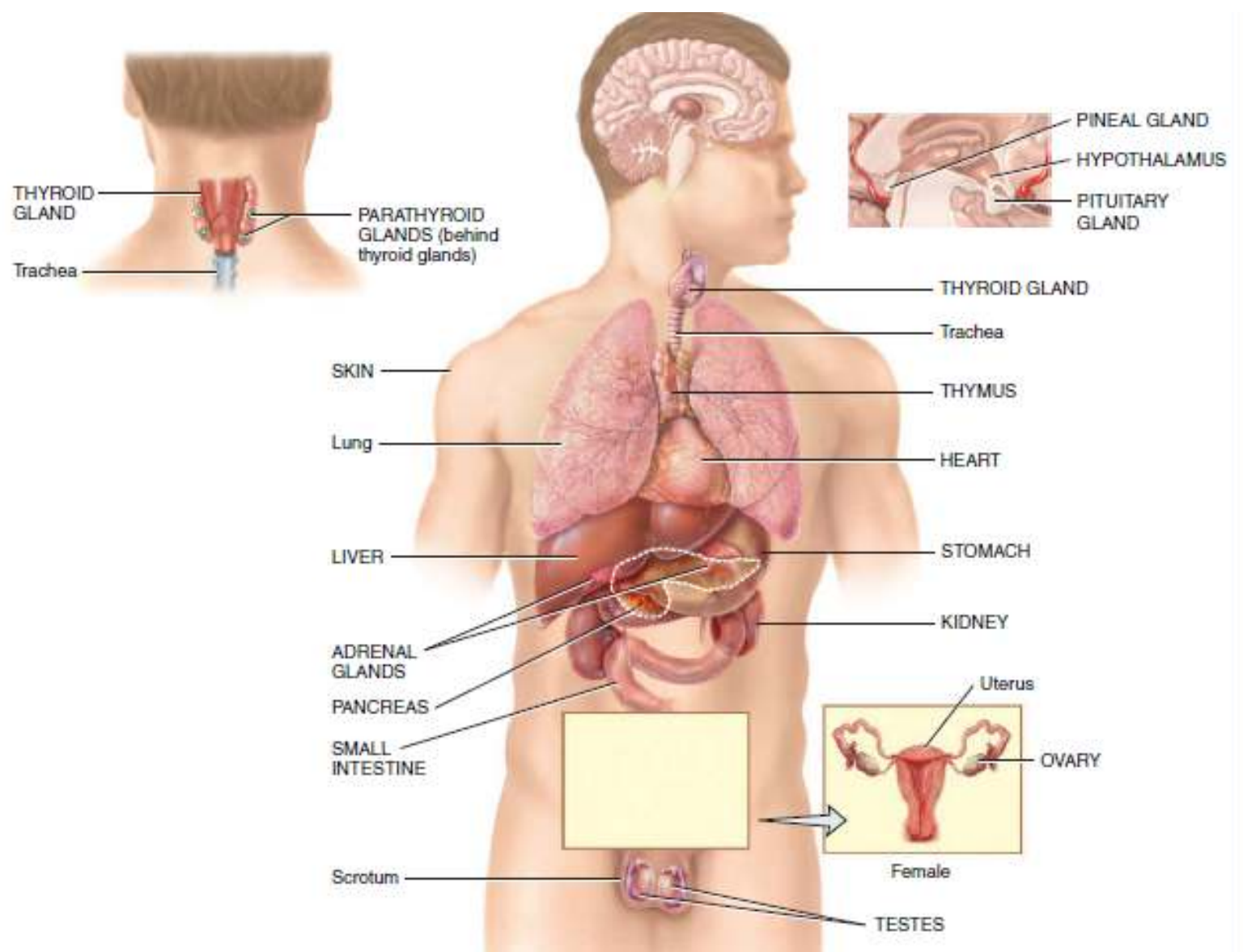

Secara umum Fungsi hormone (Tortora \& Derrickson, 2014)

1. Membantu mengatur:

a. Komposisi kimia dan volume cairan intersisial

b. Metabolism dan keseimbangan energy

c. Kontraksi otot halus dan jantung

d. Sekresi kelenjar

e. Aktivitas sistem kekebalan tubuh

2. Control tumbuh dan kembang

3. Pengontrol sistem reproduksi

4. Membantu membentuk ritme sirkandian 


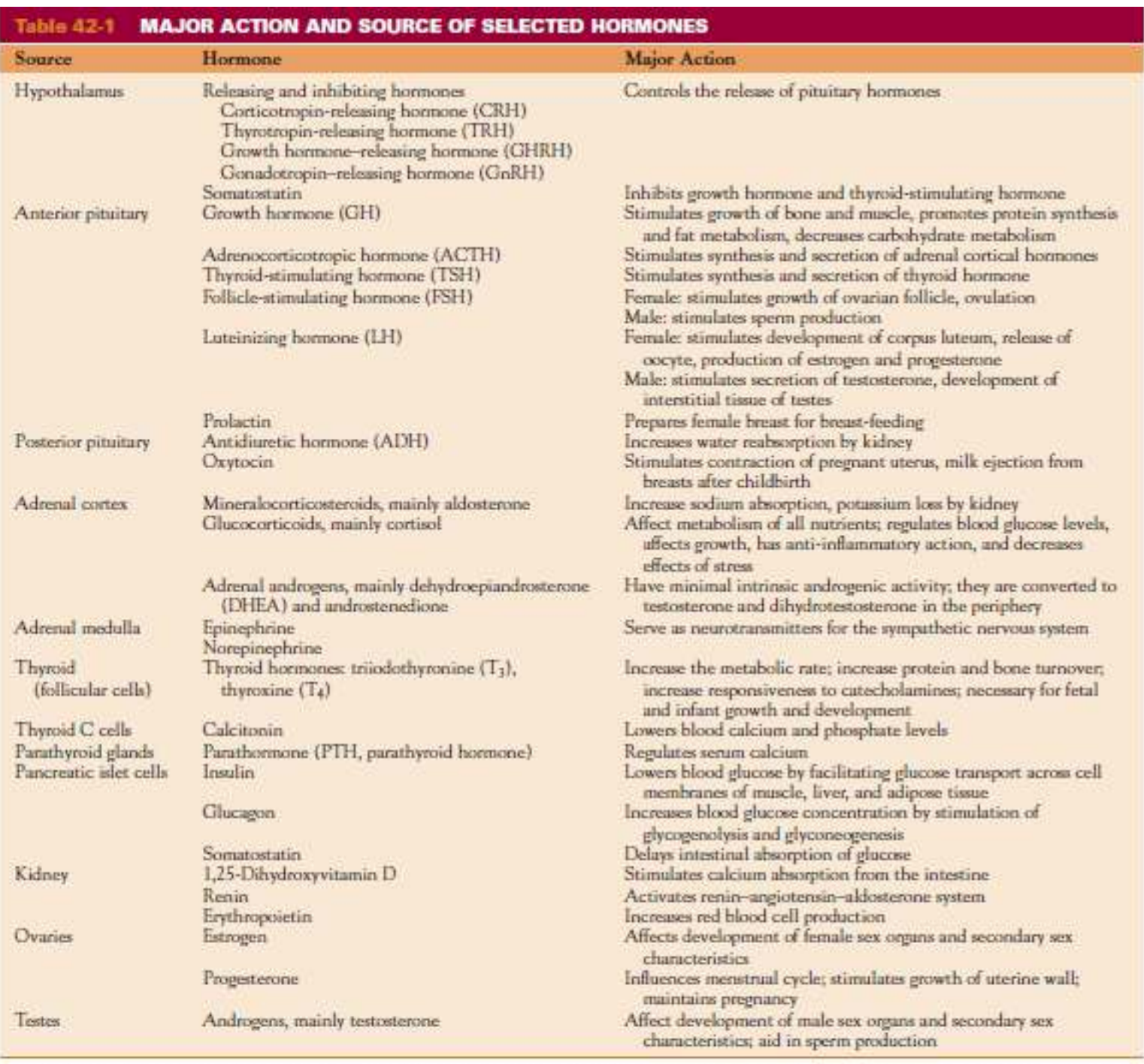

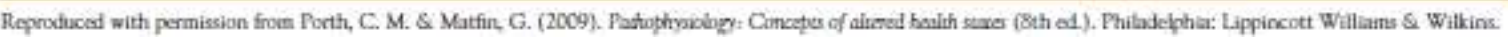

Hormone membantu mengatur fungsi organ bersama sistem syaraf. Sistem regulasi ganda ini, dimana sistem syaraf lebih cepat mempengaruhi organ dibanding sistem hormone. Sehingga menghasilkan control yang tepat bagi fungsi tubuh. Kelenjar-kelenjar endokrin terdiri dari sel sekretori disusun dalam cluster disebut acini. Tidak ada salurannya tersendiri, namun kelenjar memiliki yang kaya akan suplay darah sehingga hasil produk hormone bisa masuk melalui pembuluh darah dengan cepat. Dalam keadaan fisiologis yang sehat, konsentrasi hormone dalam aliran darah dipertahankan pada tingkat relative konstan. Negative feedback / umpang balik negative adalah mekanisme untuk mengatur konsentrasi hormone dalam darah. ketika konsentrasi hormone meningkat, produksi hormone akan dihambat. Sebaliknya, ketika konsentrasi hormone berkurang, maka produksi hormone akan lebih ditingkatkan. Hormone pada umumnya diangkut dalam cairan tubuh, dan jumlah hormone tertentu yang bersikulasi pada tubuh maka akan disesuaikan (Smeltzer et al., 2010). 


\section{Aktivitas Hormon}

\section{a. Peran reseptor hormone}

Walaupun hormon beredar ke seluruh tubuh dalam darah, hal itu hanya memberikan efek sel target yang spesifik. Hormon, seperti neurotransmitter, mempengaruhi sel target mereka dengan mengikat kimia reseptor protein yang spesifik. Hanya sel target untuk diberikan hormon memiliki reseptor yang mengikat dan mengenali hormon. Sebagai contoh, thyroid-stimulating hormone (TSH) mengikat reseptor pada sel-sel kelenjar tiroid, tetapi tidak mengikat sel-sel ovarium karena sel-sel ovarium tidak memiliki reseptor TSH. Reseptor, seperti protein seluler lainnya, yang terus-menerus disintesis dan rusak. Umumnya, sel target memiliki 2000-100.000 reseptor untuk hormon tertentu. Jika hormon yang ada lebih, jumlah reseptor sel target dapat menurun yang disebut efek down-regulasi. Misalnya, ketika tertentu sel-sel testis yang terkena konsentrasi tinggi luteinizing hormone (LH), jumlah reseptor LH menurun. Downregulation membuat sel target kurang sensitif terhadap hormon. Sebaliknya, ketika hormon kekurangan, jumlah reseptor mungkin meningkat. Fenomena ini, yang dikenal sebagai up-regulasi, membuat Target sel lebih sensitif terhadap hormon.

Hormon sintetis yang memblokir reseptor hormon bisa sebagai obat. Sebagai contoh, RU486 (mifepristone), yang digunakan untuk menginduksi aborsi, mengikat reseptor progesteron (hormon seks wanita) dan mencegah progesteron dari mengerahkan efek normal, dalam hal ini mempersiapkan lapisan rahim untuk implantasi. Ketika RU486 diberikan kepada wanita hamil, kondisi rahim yang dibutuhkan untuk memelihara suatu embrio tidak dipertahankan, perkembangan embrio berhenti, dan embrio terkelupas bersama dengan lapisan rahim. contoh ini menggambarkan prinsip endokrin yang penting: Jika hormon dicegah dari berinteraksi dengan reseptornya, hormon tidak dapat melakukan fungsi normal. 
Fispure 18.2 Coenparisan between drculating borrtoaes and

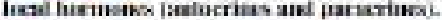

Croulaure homens: ars cerned theough the

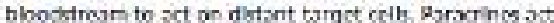
on naljobring colls, and sutocines zct on the sane cals thot prosuced thom.

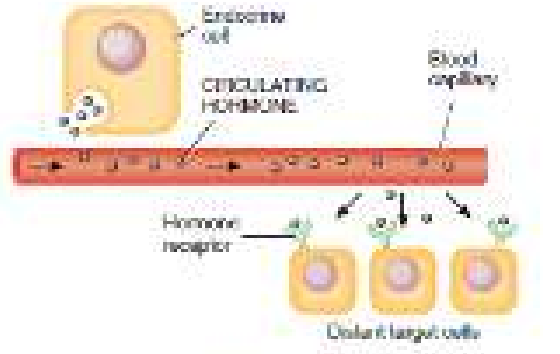

movadving homone
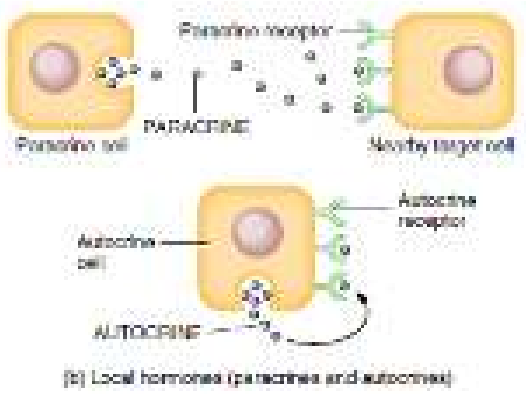

b. Sirkulasi dan hormone local

Sebagian besar circulating hormon endokrin beredar dari sel-sel sekretori menuju cairan interstitial dan kemudian ke dalam darah. Hormon lain, disebut local hormon, bertindak secara lokal pada sel tetangga atau pada sel yang sama ataupun yang disekresikan mereka tanpa terlebih dahulu memasuki aliran darah. local hormone yang bekerja pada sel-sel tetangga disebut paracrines dan mereka yang bekerja pada sel yang sama yang dikeluarkan mereka disebut autocrines. Salah satu contoh dari hormon lokal adalah interleukin-2 (IL-2), yang dilepaskan oleh sel T helper (sejenis sel darah putih) selama respon imun. IL-2 membantu mengaktifkan sel-sel kekebalan tubuh lain di dekatnya, sebuah efek parakrin. Tetapi juga bertindak sebagai autokrin

dengan merangsang sel yang sama yang dirilis untuk berkembang biak. Tindakan ini menghasilkan lebih banyak pembantu Sel T yang dapat mengeluarkan lebih banyak IL-2 dan dengan demikian memperkuat respon imun. Contoh lain dari hormon lokal gas nitric oxide (NO), yang dilepaskan oleh sel endotel yang melapisi pembuluh darah. NO menyebabkan relaksasi dari serat otot di dekatnya halus dalam pembuluh darah, yang pada gilirannya menyebabkan vasodilatasi (kenaikan diameter pembuluh darah). Efek dari berbagai vasodilatasi tersebut dari penurunan tekanan darah ke ereksi penis di laki-laki. Obat Viagra (sildenafil) meningkatkan efek merangsang oleh nitrit oksida dalam penis.

Local hormone biasanya tidak aktif dengan cepat; beredar hormon dapat berlamalama dalam darah dan memberi efek mereka untuk beberapa menit atau kadangkadang selama beberapa jam. Pada waktu, hormon beredar mengalami inaktivasi oleh hati dan diekskresikan oleh ginjal. Di kasus ginjal atau gagal hati, tingkat berlebihan hormon dapat bertambah dalam darah.

\section{c. Klasifikasi kimia hormone}

Secara kimia, hormon dapat dibagi menjadi dua kelas secara luas: hormon yang larut dalam lemak (Lipid-Soluble Hormones), dan hormone yang larut dalam air (WaterSoluble Hormones). Klasifikasi kimia ini juga berguna secara fungsional, karena dua kelas mengakibatkan efek mereka berbeda.

1) Larut dalam lemak

Hormon yang larut dalam lemak termasuk hormon steroid, tiroid hormon, dan nitric oxide.

a) Hormon steroid yang berasal dari kolesterol. setiap steroid Hormon ini unik karena adanya bahan kimia yang berbeda kelompok yang melekat di 
berbagai tempat di empat cincin pada inti strukturnya. Perbedaan kecil memungkinkan untuk keragaman besar fungsi.

b) Dua hormon tiroid ( $\mathrm{T} 3$ dan $\mathrm{T} 4$ ) disintesis dengan menghubungkan yodium ke amino acid tyrosine. Adanya dua cincin benzena dalam T3 atau T4 molekul membuat molekul molekul sangat larut lemak

c) gas nitric oxide (NO) merupakan sebuah hormon dan neurotransmiter. Sintesis biasanya dikatalisis oleh enzim nitric oxide synthase.

2) Larut dalam air

Hormon yang larut dalam air termasuk amine hormones, peptide and protein hormones, and eicosanoid hormones.

a) amine hormones disintesis oleh decarboxylating (menghilangkan molekul CO2) dan sebaliknya memodifikasi asam amino tertentu. Mereka disebut amina karena mereka mempertahankan gugus amino (-NH3). Katekolamin-epinefrin, norepinefrin, dan dopamin, disintesis dengan memodifikasi tirosin asam amino. Histamin disintesis dari amino histidin asam oleh sel mast dan trombosit. serotonin dan melatonin yang berasal dari triptofan.

b) Peptide hormones and protein hormones yang asam aminonya polimer. Hormon peptida yang lebih kecil terdiri dari rantai 3-49 asam amino; hormon protein yang lebih besar termasuk 50 untuk 200 asam amino. Contoh hormon peptida yang antidiuretik hormon dan oksitosin; hormon protein dilengkapi pada manusia yaitu hormon pertumbuhan dan insulin. Beberapa hormon protein, seperti thyroid-stimulating hormone, telah terpasang kelompok karbohidrat dan karenanya glikoprotein hormon.

c) eicosanoid hormones yang berasal dari asam arakidonat, yang 20-karbon Asam lemak. Dua jenis utama dari eikosanoid merupakan prostaglandin (PG) dan leukotrien (LTs). eikosanoid adalah hormon lokal yang penting, dan mereka dapat bertindak sebagai yang hormon bersirkulasi juga. 


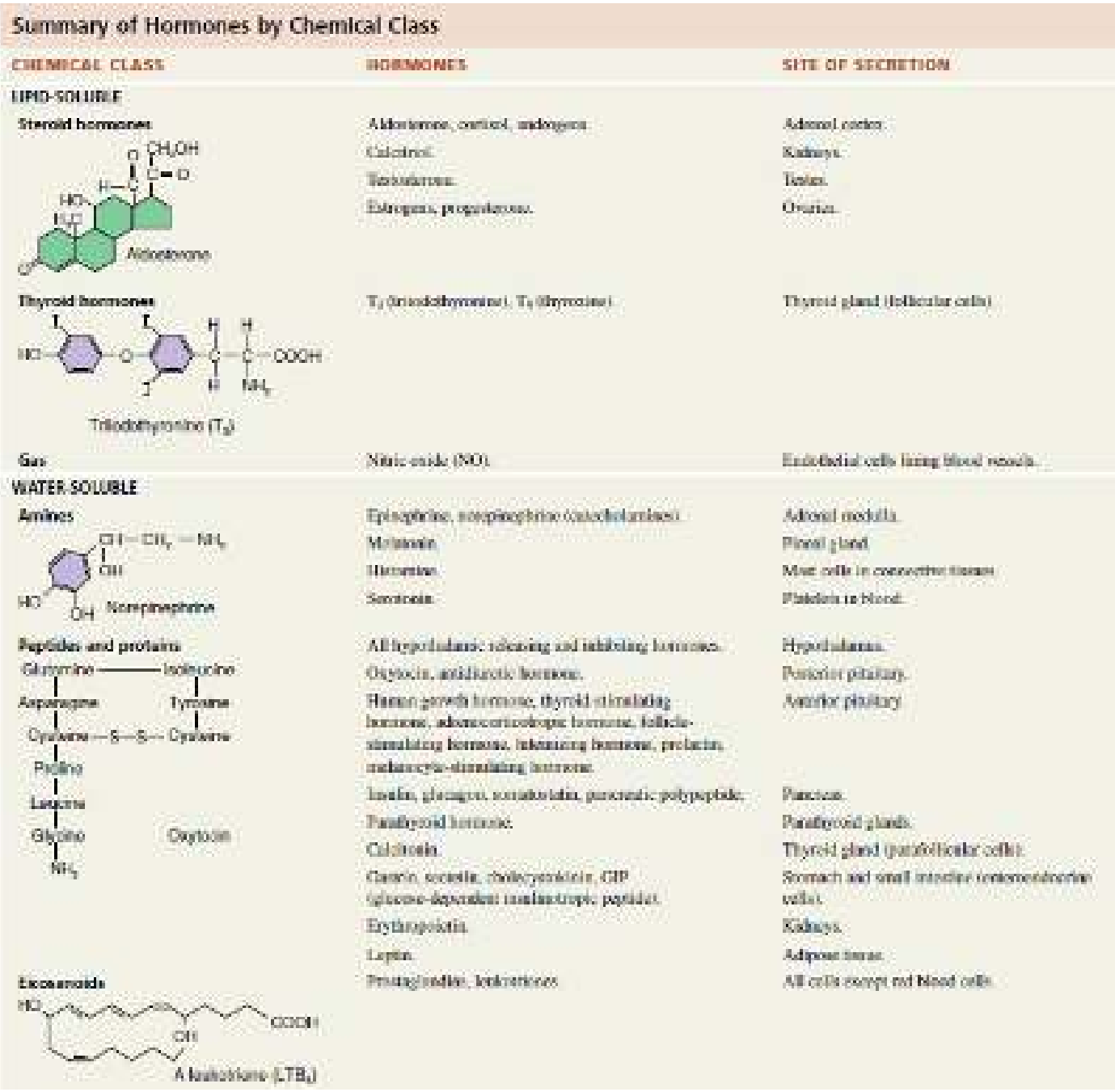

d. Transport hormone dalam darah

Sebagian besar molekul hormon yang larut dalam air beredar di plasma darah "bebas" (tidak terikat dengan molekul lain), tetapi kebanyakan molekul hormon larut-lemak terikat dengan Protein transportasi. Protein transportasi, yang disintesis oleh

Sel-sel di hati, memiliki tiga fungsi:

1) Protein transportasi membuat hormon larut-lemak untuk sementara larut dalam air, sehingga meningkatkan kelarutannya dalam darah.

2) menghambat lewatnya molekul hormon yang kecil melalui Mekanisme penyaringan di dalam ginjal, sehingga memperlambat laju kehilangan hormon dalam urin.

3) menyediakan cadangan hormon.

Secara umum, 0,1-10\% dari molekul hormon larut-lemak tidak terikat pada protein transportasi. Sebagian bebas ini berdifusi dari kapiler, mengikat reseptor, dan memicu tanggapan. Sebagai molekul hormon bebas meninggalkan darah dan berikatan dengan reseptor mereka, protein transportasi lepaskan yang baru untuk mengisi bebas sebagian kecil. 
BUKU AJAR ANATOMI FISIOLOGI KEPERAWATAN MEDIKAL BEDAH 


\section{Mekanisme Aksi Hormon}

Respon terhadap hormon tergantung pada kedua hormon itu sendiri dan sel target. Berbagai sel target bereaksi berbeda terhadap hormon yang sama. Insulin, misalnya, merangsang sintesis glikogen pada sel hati dan sintesis trigliserida dalam adipose sel. Respon terhadap hormon ini tidak selalu sintesis molekul baru, seperti halnya insulin. hormonal lainnya efek termasuk mengubah permeabilitas membran plasma, stimulasi transport zat yang kedalam atau keluar dari target sel, mengubah laju reaksi metabolisme tertentu, atau menyebabkan kontraksi otot polos atau otot jantung. Pada bagian, efek ini bervariasi hormon yang mungkin karena satu hormon dapat menggerakkan beberapa tanggapan seluler yang berbeda.

Namun, hormon harus terlebih dahulu "mengumumkan kedatangannya" ke target sel dengan mengikat reseptor. Reseptor untuk lipidsolublehormon merupakan terletak di dalam sel target. Reseptor untuk hormon yang larut dalam air adalah bagian dari membran plasma dari sel target.

\section{a. Aksi hormone larut lemak}

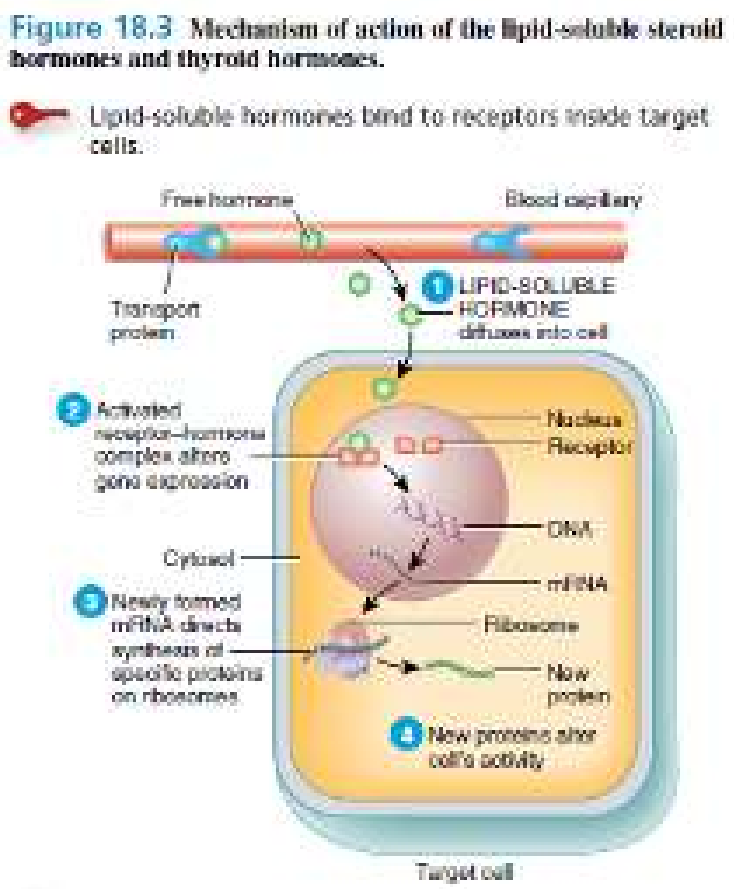

(1) Sebuah molekul hormone larut lemak yang bebas berdifusi dari darah melalui cairan intersisiel dan melalui lipid bilayer (lapisan ganda) dari membrane plasma kedalam sel

(2) Jika sel adalah sel target, hormon mengikat dan mengaktivasi reseptor terletak di sitosol atau nucleus. mengaktifkan reseptor-hormon yang kompleks kemudian mengubah ekspresi gen: Hal ini membuat gen yang spesifik dari DNA nuklir menjadi aktif atau tidak aktif.

(3) Karena DNA ditranskripsi, messenger RNA (mRNA) membentuk yang baru, meninggalkan nukleus, dan memasuki sitosol. Di sana, hal itu mesintesis protein baru, sering kali suatu enzim, di ribosom.

(4) Protein baru mengubah aktivitas sel dan menyebabkan respon tipikal hormon.

\section{b. Aksi hormone larut air}

Karena amine, peptida, protein, dan hormon eicosanoid merupakan tidak lemaklarut, mereka tidak dapat menyebar melalui lapisan ganda lipid membran plasma dan mengikat reseptor di sel target. Sebaliknya, hormon yang larut dalam air berikatan dengan reseptor yang menonjol dari permukaan sel target. Reseptor merupakan transmembran bagian integral protein dalam membran plasma. Ketika larut dalam air hormon berikatan dengan reseptornya di permukaan luar dari membran plasma, ia bertindak sebagai Messenger pertama. Messenger pertama (Hormon) kemudian menyebabkan produksi messenger kedua di dalam sel, di mana 
hormon spesifik stimulasi berlangsung. Salah satu second messenger yang sering adalah AMP siklik (cAMP). neurotransmiter, neuropeptida, dan beberapa transduksi

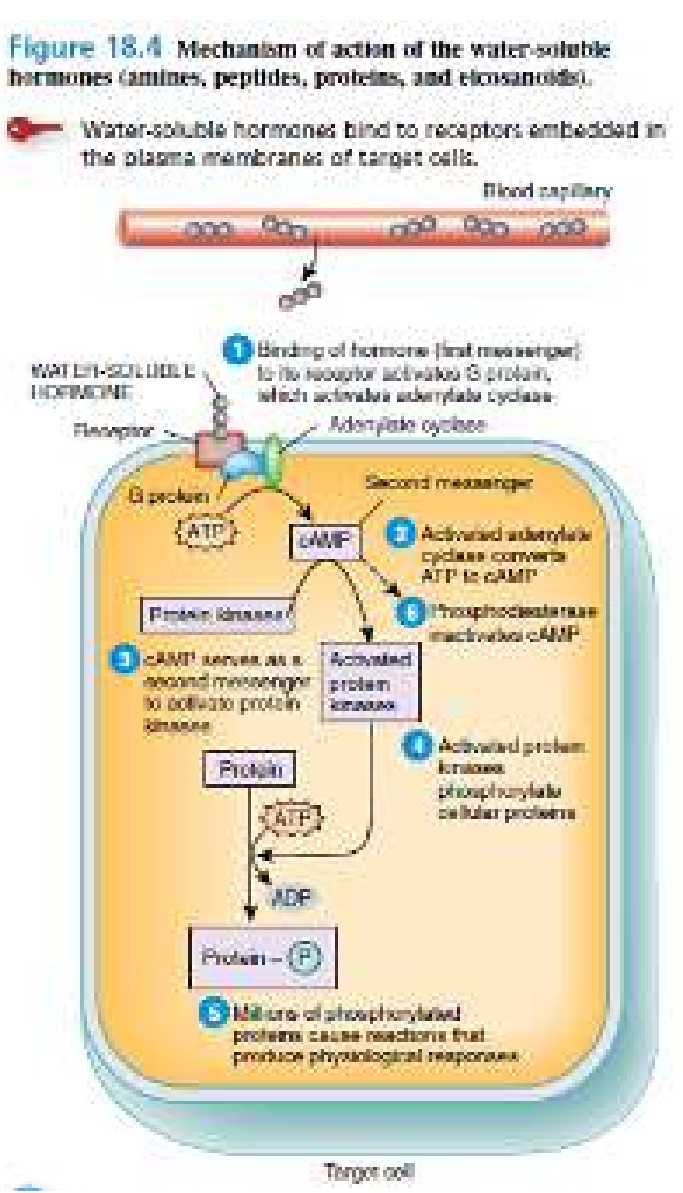
sensori mekanisme juga bertindak melalui Sistem second messenger.

(1) Hormon larut dalam air (messenger pertama) berdifusi dari darah melalui cairan interstitial dan kemudian mengikat reseptor pada permukaan bagian luar membran plasma target sel. Kompleks hormon-reseptor mengaktifkan membran protein yang disebut protein $G$. Protein $G$ yang mengaktifkan pada gilirannya mengaktifkan adenylate cyclase.

(2) Adenylate cyclase mengubah ATP menjadi AMP cyclic (cAMP). Karena aktif enzim site di atas permukaan bagian dalam dari membran plasma, reaksi tersebut terjadi di sitosol dari sel.

(3) Cyclic AMP (mesegger kedua) mengaktifkan satu atau lebih protein kinase, yang mungkin bebas dalam sitosol atau terikat pada membran plasma. Sebuah protein kinase adalah enzim yang phosphorylates (gugus fosfat) protein seluler lainnya (seperti enzim). Donor fosfat grup adalah ATP, yang diubah menjadi ADP.

(4) Activated protein kinase memfosforilasi satu atau lebih sel protein. Fosforilasi mengaktifkan beberapa protein dan menginaktivasi lain, bukan seperti menyalakan sebuah tombol aktif atau tidak aktif.

(5) Protein terfosforilasi pada gilirannya menyebabkan reaksi yang menghasilkan respon fisiologis tubuh. Protein kinase yang berbeda ada dalam sel target yang berbeda dan dalam organel yang berbeda dari sel target yang sama. Dengan demikian, salah satu protein kinase kekuatan memicu terjadinya sintesis glikogen, yang kedua dapat menyebabkan kerusakan dalam trigliserida, ketiga dapat meningkatkan sintesis protein, dan lain sebagainya. Seperti tercantum dalam langkah 4, fosforilasi oleh protein kinase juga dapat menghambat protein tertentu. Sebagai contoh, beberapa kinase melepaskan epinefrin ketika berikatan sel hati menonaktifkan enzim yang diperlukan untuk glikogen sintesis.

(6) Setelah periode singkat, enzim yang disebut phosphodiesterase menginaktivasi cAMP. Dengan demikian, sel respon akan dinonaktifkan kecuali molekul hormon baru lainnya yang selanjutnya untuk mengikat reseptor dalam membran plasma. 


\section{c. Interaksi Hormon}

Respon dari sel target untuk hormon tergantung pada (1) konsentrasi hormon dalam darah, (2) banyaknya reseptor hormon target sel, dan (3) pengaruh yang diberikan oleh hormon lainnya. Sebuah sel target merespon lebih keras ketika tingkat hormon naik atau ketika memiliki lebih reseptor (upregulation). Selain itu, aksi beberapa hormon pada target Sel-sel memerlukan simultan atau baru paparan terhadap hormon kedua. Pada kasus tersebut, hormon kedua dikatakan memiliki efek yang permisif. Sebagai contoh, epinefrin sendirian hanya lemah dalam merangsang lipolisis (pemecahan trigliserida), tapi ketika sejumlah kecil hormon tiroid (T3 dan T4) yang hadir, dalam jumlah yang sama epinefrin merangsang lipolisis jauh lebih kuat. Kadang-kadang hormon permisif meningkatkan jumlah dari reseptor untuk hormon lainnya, dan kadang-kadang mendorong sintesis suatu enzim yang diperlukan untuk mengekspresikan yang lain efek hormon itu.

Ketika efek dua hormon yang bekerja sama lebih besar atau lebih ekstensif daripada efek masing-masing hormon bertindak sendiri, dua hormon yang dikatakan memiliki efek sinergis. Sebagai contoh, perkembangan normal oosit dalam ovarium membutuhkan baik follicle-stimulating hormone dari hipofisis anterior dan estrogen dari ovarium. Hormon tidak saja sudah cukup. Ketika salah satu hormon menentang tindakan hormon lain, dua hormon yang dikatakan memiliki efek antagonis. Contoh dari pasangan antagonis hormon insulin, yang meningkatkan sintesis glikogen oleh sel-sel hati, dan glukagon, yang merangsang pemecahan glikogen di hati.

\section{Control sekresi hormone}

Pelepasan hormon sebagian besar terjadi dalam singkat, dengan sedikit atau bahkan tanpa sekresi. Ketika distimulasi, kelenjar endokrin akan melepaskan hormon dalam lebih sering, sehingga peningkatan konsentrasi hormon dalam darah. Dalam ketiadaan stimulasi,tingkat hormon darah menurun. Kontrol sekresi biasanya mencegah kelebihan atau kekurangan produksi. dari setiap hormon yang diproduksi untuk membantu mempertahankan homeostasis. Sekresi hormon diatur oleh (1) sinyal dari saraf sistem, (2) perubahan kimia dalam darah, dan (3) hormon lainnya. Sebagai contoh, impuls saraf ke medula adrenal mengatur pelepasan epinefrin; Tingkat $\mathrm{Ca} 2$ dalam darah mengatur sekresi hormon paratiroid; dan hormon dari anterior hipofisis (adrenocorticotropic hormone) merangsang pelepasan kortisol oleh korteks adrenal. Sebagian besar Sistem peraturan hormonal bekerja melalui umpan balik negatif, tetapi beberapa beroperasi melalui umpan balik positif. Sebagai contoh, selama melahirkan, hormon oksitosin merangsang kontraksi rahim, dan kontraksi rahim pada gilirannya merangsang lebih oksitosin direlease, efek umpan balik positif.

\section{Gland pituitary (hipofisis)}

Selama bertahun-tahun, kelenjar pituitari atau hipofisis disebut "master" kelenjar endokrin karena mengeluarkan beberapa hormon yang mengontrol kelenjar endokrin lainnya. Kita sekarang tahu bahwa hipofisis kelenjar itu sendiri memiliki master hipotalamus. Daerah ini kecil di otak bawah, thalamus adalah penghubung utama antara sistem saraf dan endokrin. Sel-sel dalam hipotalamus mensintesis setidaknya sembilan hormon yang berbeda, dan kelenjar pituitari mensekresi tujuh. Bersama-sama, hormon 
ini memainkan peran penting dalam regulasi hampir semua aspek pertumbuhan, perkembangan, metabolisme, dan homeostasis (Tortora \& Derrickson, 2014).

Kelenjar pituitari mempunyai struktur seperti kacang yang berdiameter $1-1,5 \mathrm{~cm}(0,5 \mathrm{in}$. terletak pada fossa hypophyseal sela tursika tulang sphenoid. Menempel di hipotalamus dengan tangkai, infundibulum dan memiliki dua bagian anatomis dan fungsional yang terpisah: hipofisis anterior dan hipofisis posterior. Hipofisis anterior (lobus anterior), juga disebut adenohypophysis, menyumbang sekitar $75 \%$ dari total berat kelenjar dan terdiri dari jaringan epitel. Hipofisis anterior terdiri dari dua bagian pada orang dewasa: distalis pars adalah bagian yang lebih besar, dan tuberalis pars bentuknya ada kantung di sekitar infundibulum. hipofisis Posterior (posterior lobus), juga disebut neurohypophysis, terdiri dari jaringan saraf. Ini juga terdiri dari dua bagian: nervosa pars, bagian bulbar yang lebih besar, dan infundibulum. ada wilayah ketiga dari kelenjar pituitari yang disebut intermedia pars atrophies, selama perkembangan janin manusia dan tidak lagi ada sebagai lobus tersendiri pada orang dewasa. Namun, beberapa sel yang bermigrasi ke bagian yang berdekatan dari hipofisis anterior.

\section{a. Hipofisis Anterior}

Hipofisis anterior atau adenohypophysis mengeluarkan hormon yang mengatur berbagai kegiatan tubuh, dari pertumbuhan reproduksi. Pelepasan hormon hipofisis anterior distimulasi dengan merilis hormon dan menekan dengan menghambat hormon dari hipotalamus. Dengan demikian, hormon hipotalamus adalah merupakan link penting antara sistem saraf dan endokrin.

\section{Sistem Portal Hypophyseal}

Hormon hipotalamus yang melepaskan atau menghambat hormon hipofisis anterior sampai di hipofisis anterior melalui sistem portal. Umumnya, darah yang mengalir dari jantung melalui arteri ke kapiler ke vena dan kembali ke jantung. Dalam sistem portal, darah yang mengalir dari satu jaringan kapiler ke vena portal, dan kemudian ke jaringan kapiler kedua sebelum kembali ke jantung. Nama sistem portal mengindikasikan lokasi jaringan kapiler kedua. Dalam sistem portal hypophyseal, darah yang mengalir dari kapiler di hipotalamus ke dalam pembuluh darah vena portal menuju ke kapiler hipofisis anterior. 
Figure 18.5 Hypothalamus and pituitary gland, and their blood supply. Releasing and inhibiting hormones synthosizod by hypothalamic neurosecretory oells are transpoirted within axons and relcased at the axon terminals. The

hormones diffuse into capillaries of the primary plexus of the hypophyseal portal system and are carried by the hypophyseal pertal veins to the secundury plecus of the hypophyseal porlal system for distribution to target celis in the anterior pituitury.

Hypothalamic hormones are an important link between the nervous and endocrine systems.
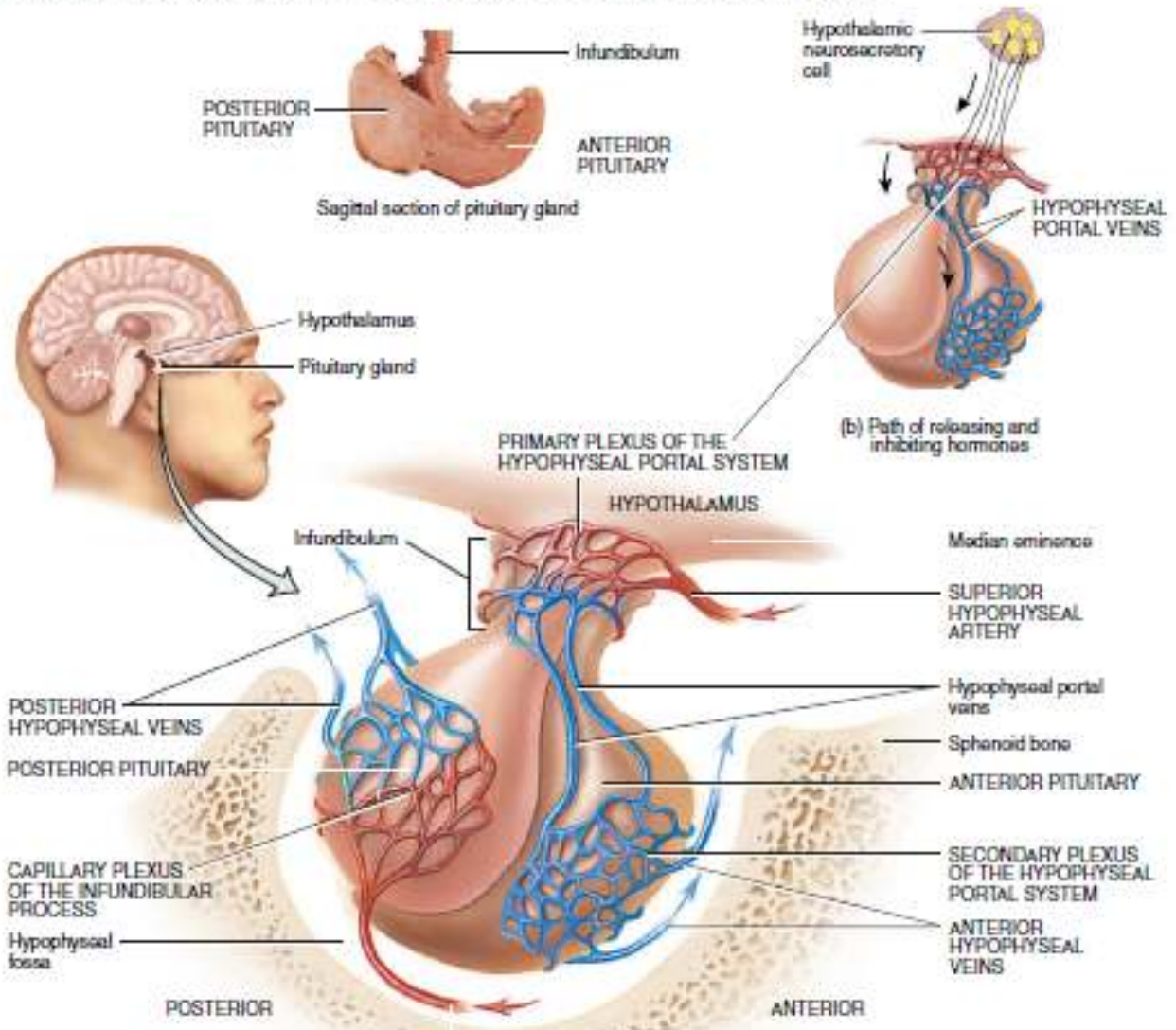

Intarior hypoptyseal artary

(a) Rolationship of tho hypothalamus to the ptuiary gland
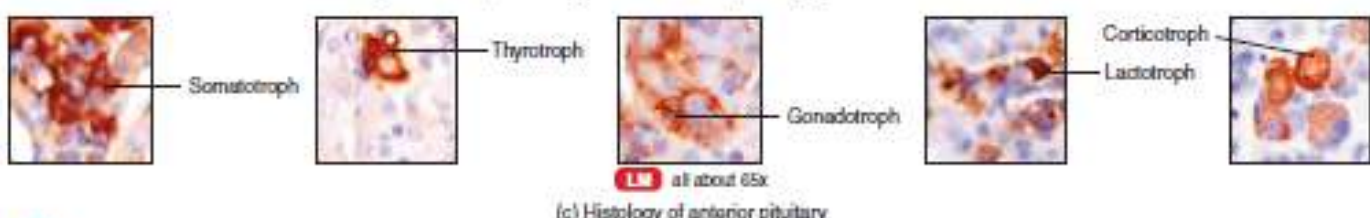

(c) Histology of antonior pitutary

Arteri hypophyseal superior, cabang arteri karotis interna, membawa darah ke hipotalamus. Di persimpangan eminensia median dari hipotalamus dan infundibulum, arteri ini terbagi menjadi jaringan kapiler disebut pleksus utama dari sistem portal hypophyseal. Dari pleksus primer, aliran darah masuk ke dalam pembuluh darah Portal hypophyseal melewati luar infundibulum. Di hipofisis anterior, vena Portal hypophyseal membagi lagi dan membentuk jaringan kapiler lain yang disebut pleksus sekunder dari sistem portal hypophyseal.

Di atas Chiasm optik adalah kelompok neuron khusus yang disebut sel neurosecretory. Mereka mensintesis hipotalamus tersebut merilis dan menghambat hormon pada tubuh sel mereka dan mengemas hormon di dalam vesikel, dimana sampai di terminal akson oleh transportasi aksonal. Impuls saraf merangsang vesikel mengalami eksositosis. Hormon kemudian berdifusi ke dalam pleksus utama dari sistem portal hypophyseal. Dengan Cepat, hormon hipotalamus mengalir dengan 
darah melalui vena portal dan ke pleksus sekunder. Jalur langsung ini memungkinkan hormon hipotalamus untuk segera bertindak pada sel hipofisis anterior, sebelum hormon dilarutkan atau hancur dalam sirkulasi umum. Hormon disekresi oleh sel-sel hipofisis anterior masuk ke dalam kapiler pleksus sekunder, dimana mengalir menuju vena hypophyseal anterior dan keluar ke sirkulasi umum. Hormon hipofisis anterior kemudian melakukan perjalanan ke menargetkan jaringan di seluruh tubuh. Hormonhormon hipofisis anterior yang bekerja pada kelenjar endokrin lain disebut hormon tropik atau tropins.

Lima jenis sel-somatotrophs hipofisis anterior, thyrotrophs, gonadotrophs, lactotrophs, dan corticotrophs-mensekresi tujuh hormon.

1) Somatotrophs mengeluarkan human Growth Hormone (hGH), juga dikenal sebagai somatotropin. human Growth Hormone pada gilirannya merangsang beberapa jaringan untuk mengeluarkan Insulinlike Growth Factors (IGFs), hormon yang merangsang pertumbuhan tubuh secara umum dan mengatur aspek metabolisme.

2) Thyrotrophs mengeluarkan thyroid-stimulating hormone (TSH), juga dikenal sebagai thyrotropin. TSH mengendalikan sekresi dan kegiatan lain dari kelenjar tiroid.

3) Gonadotrophs mengeluarkan dua gonadotropin: follicle-stimulating hormone (FSH) dan luteinizing hormone (LH). FSH dan LH baik bertindak pada gonad. Mereka menstimulasi sekresi estrogen dan progesteron dan pematangan oosit dalam ovarium, dan mereka merangsang produksi sperma dan sekresi testosteron di testis.

4) Lactotrophs mengeluarkan prolaktin (PRL), yang memulai produksi ASI di kelenjar payudara.

5) Corticotrophs mengeluarkan adrenocorticotropic hormone (ACTH), juga dikenal sebagai corticotropin, yang menstimulasi korteks adrenal untuk mensekresikan glukokortikoid seperti kortisol. Beberapa corticotrophs, sisasisa pars intermedia, juga mengeluarkan melanocyte-stimulating hormone (MSH).

\begin{tabular}{|c|c|c|c|}
\hline \multicolumn{4}{|l|}{ TABLE 18.3} \\
\hline \multicolumn{4}{|c|}{ Hormones of the Anterlor Pituitary } \\
\hline Honmone & SECHETED \&Y & 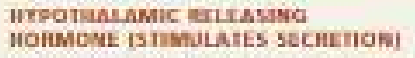 & 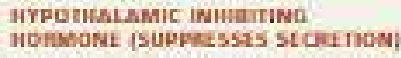 \\
\hline 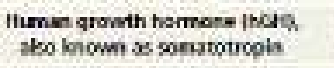 & Sondertints. & 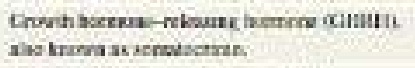 & 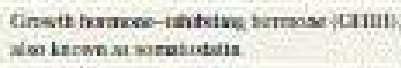 \\
\hline 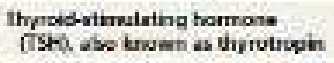 & Throurepta & 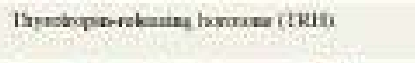 & 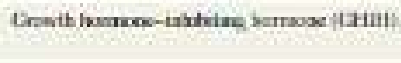 \\
\hline RAlsdo-stirulvitios bornens (PST) & Guabuagin & 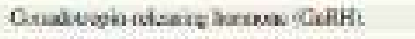 & $=$ \\
\hline Leosinising homeone RHO & Gctaboropir: & 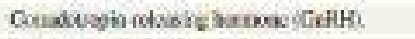 & 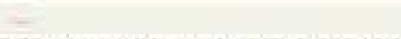 \\
\hline Frobstin ores & lacounghs: & 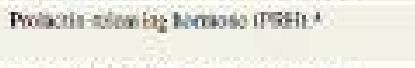 & 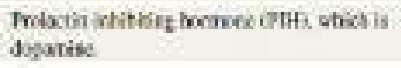 \\
\hline 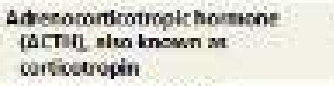 & Ciniruprote & 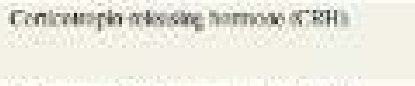 & - \\
\hline 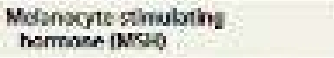 & Carsuabupto. & 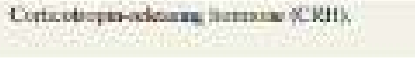 & Loparas. \\
\hline
\end{tabular}




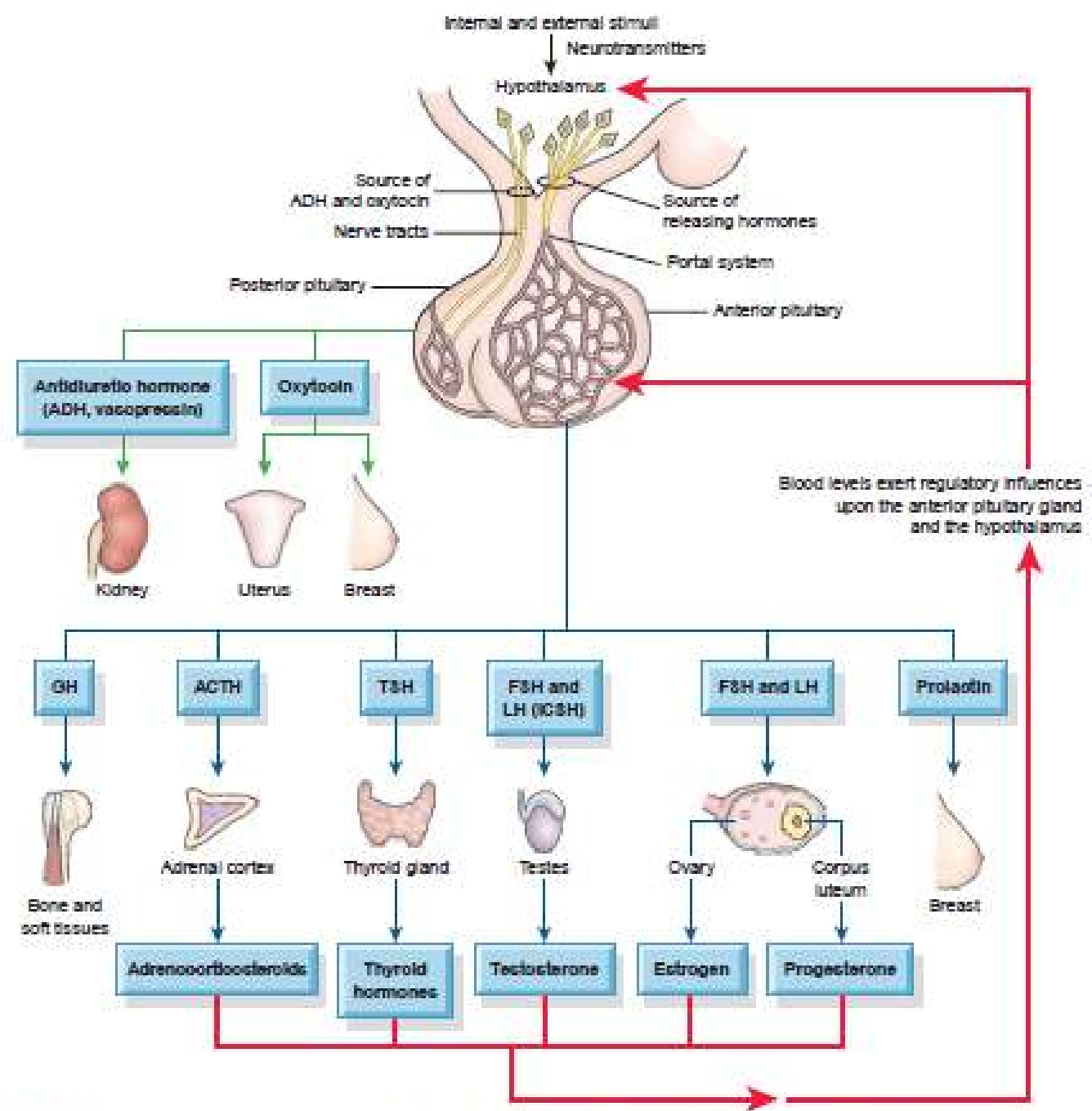

Flgure 42-2 The pituitary gland, the ralationship of the brain to pituitary action, and the hormones socrated by the anterior and posterior pituitary lobes. ACTH, adrenacorticutropic hormone; ACH, antidiuretic hormone; FSH, follicle-stimulating hormone; GH, growth hormona; ICSH, intarstitial call stimelating hormone; EH, lutainizing hormone: TSH, thyruid-stimulating hormone. 


\section{Pengendalian Sekresi oleh hipofisis anterior}

Figure 18.6 Neyadue fecdhack resalution of hpothibanie

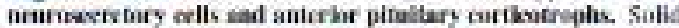

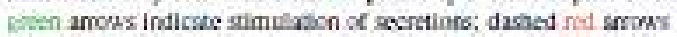
indicate ahitution of secretion via regative fecdtoxk.

Q- Cot sol yecreted by the atrenal curtex suppresses. secrotion of CRH and $\mathrm{ACTH}$.

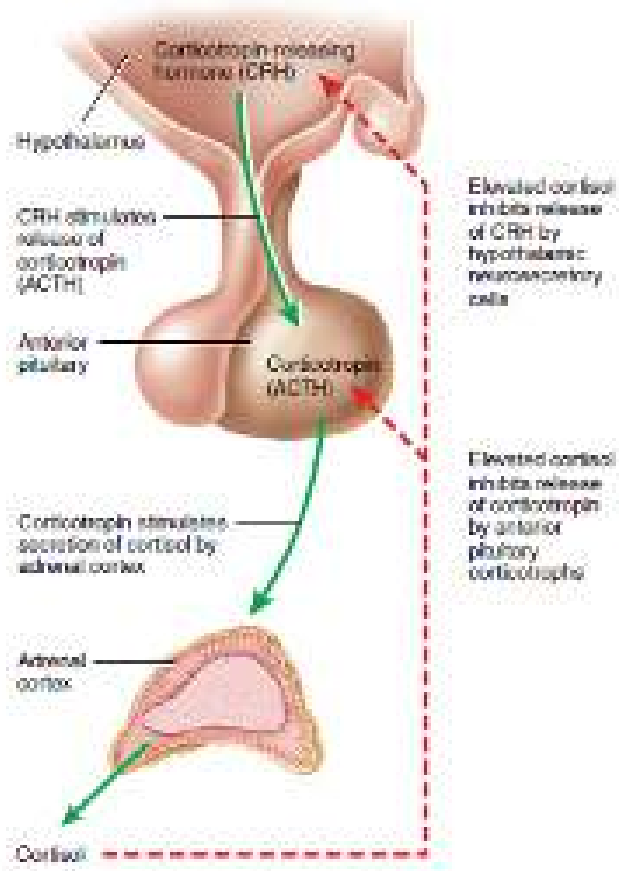

Sekresi hormon hipofisis anterior diatur dalam dua cara. Pertama, sel neurosecretory di hipotalamus mensekresi lima hormon dan merelease, yang menstimulasi sekresi hormon hipofisis anterior, dan dua hormon penghambat, yang menekan sekresi hormon hipofisis anterior. Kedua, umpan balik negatif berbentuk hormon yang dikeluarkan oleh kelenjar Target menurunkan sekresi untuk tiga jenis sel hipofisis anterior. Dalam umpan balik negatif seperti loop, aktivitas sekresi dari thyrotrophs, gonadotrophs, dan corticotrophs menurun bila kadar hormon kelenjar target mereka meningkat. Misalnya, adrenocorticotropic hormone (ACTH) menstimulasi kelenjar korteks adrenal untuk mensekresi glukokortikoid, terutama kortisol.

Selanjutnya, tingkat darah yang meningkat kortisol menurunkan sekresi baik corticotropin dan corticotropin-releasing hormone $(\mathrm{CRH})$ dengan cara menekan aktivitas corticotrophs hipofisis anterior dan sel neurosecretory hipotalamus.

\begin{tabular}{|c|c|c|c|}
\hline \multicolumn{4}{|c|}{ Hormones of the Anterior Pituitary } \\
\hline HonMose & SECEATED Br & 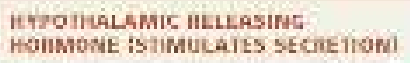 & 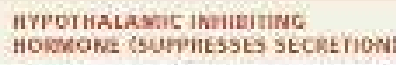 \\
\hline 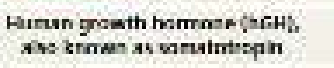 & Smenengts & 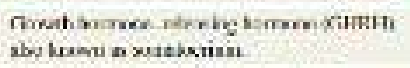 & 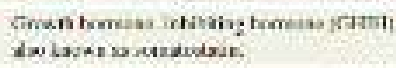 \\
\hline 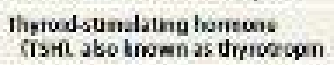 & Tysomin. & 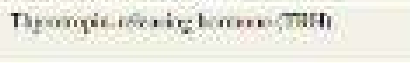 & 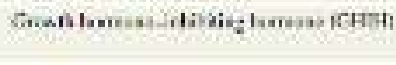 \\
\hline 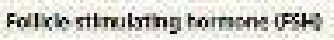 & Gerabation & 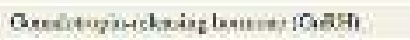 & - \\
\hline Luileinbieg hamarn ture & Fonwantpe & 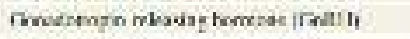 & \\
\hline Pretsettin IFES; & Lavisbate. & 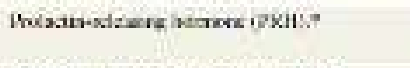 & 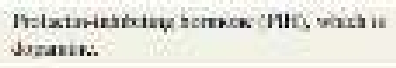 \\
\hline 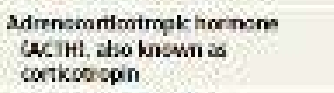 & 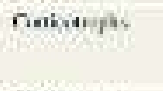 & 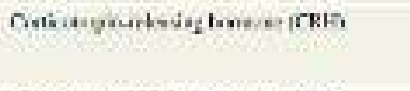 & - \\
\hline 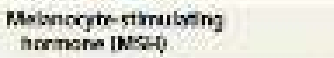 & Daknation & 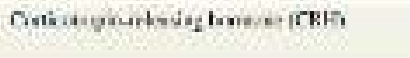 & Dringe \\
\hline
\end{tabular}

\section{Human Growth Hormone and Insulinlike Growth Factors}

Somatotrophs adalah sel sebagian besar banyak di hipofisis anterior, dan human growth hormone $(\mathrm{hGH})$ merupakan hormon yang paling berlimpah dihipofisis anterior. Fungsi utama dari hGH adalah untuk meningkatkan sintesis dan sekresi hormon protein kecil yang disebut insulinlike growth factor atau somatomedins. sebagai respon human growth hormon, sel-sel di hati, otot rangka, kartilago, tulang, dan jaringan lainnya mensekresikan IGFs, dimana mungkin juga masuk ke 
aliran darah dari hati atau berperan secara lokal di jaringan lain sebagai autocrines atau paracrines.

Fungsi IGFs antara lain sebagai berikut:

1) IGFs menyebabkan sel untuk tumbuh dan berkembang biak dengan cara meningkatkan uptake asam amino ke dalam sel dan mempercepat sintesis protein. IGFs juga memperkecil pemecahan protein dan pemanfaatan asam amino untuk produksi ATP. Karena efek dari IGFs, human growth hormone meningkatkan tingkat pertumbuhan kerangka dan otot rangka selama masa kanak-kanak dan remaja. Pada orang dewasa, human growth hormone dan IGFs membantu mempertahankan massa otot dan tulang dan meningkatkan penyembuhan luka dan perbaikan jaringan.

2) IGFs juga meningkatkan lipolisis di jaringan adiposa, yang menghasilkan peningkatan penggunaan fatty acids dalam merilis untuk memproduksi ATP oleh sel-sel tubuh.

3) Selain mempengaruhi protein dan lipid metabolisme, growth hormone manusia dan IGFs mempengaruhi metabolisme karbohidrat dengan cara menurunkan uptake glukosa, dimana mengurangi penggunaan glukosa untuk memproduksi ATP oleh sel-sel tubuh sebagian besar. Tindakan ini akan menyimpan glukosa sehingga tersedia untuk neuron produksi ATP di saat kekurangan glukosa. IGFs dan human growth hormone juga menstimulasi selsel hati untuk melepaskan glukosa ke dalam darah.

Figure 18.7 Effects of human growth hormone (hGH) and insulinlike growth factors (IGFs). Solid green arrows indicate stimulation of secretion; dashed red arrows indicate inhibition of secretion via negative feedback.

Secretion of hGH is stimulated by growth hormonereleasing hormone (GHRH) and inhibited by growth hormone-Inhibiting hormone (GHIH).

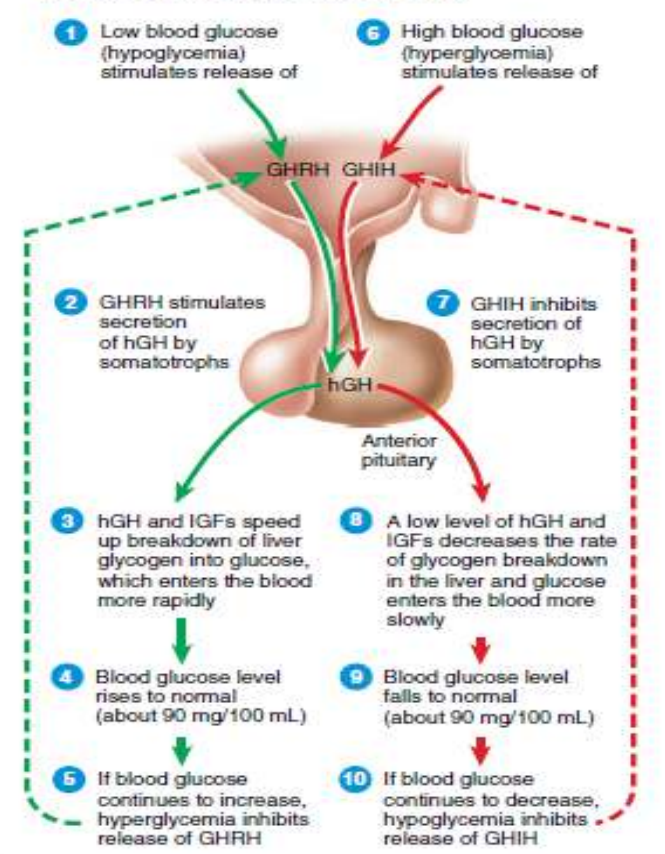

Somatotrophs di hipofisis anterior merelease human growth hormone setiap beberapa jam, khususnya saat tidur. Kegiatan ini dikontrol terutama oleh dua hormon hipotalamus: (1) growth hormone-releasing hormone (GHRH) meningkatkan sekresi human growth hormone, dan (2) growth hormone-inhibiting hormone (GHIH) dapat menekan produksi hormon. Regulator utama dari sekresi GHRH dan GHIH merupakan tingkat glukosa darah.

1) Hipoglikemia suatu konsentrasi glukosa darah yang rendah secara abnormal, menstimulasi hipotalamus untuk mensekresikan GHRH, yang mengalir menuju hipofisis anterior di vena Portal hypophyseal

2) Pada mencapai hipofisis anterior, GHRH menstimulasi somatotrophs untuk melepaskan human growth hormone. 
3) Human growth hormone menstimulasi sekresi growth factors insulinlike, yang mempercepat pemecahan glycogen di hati menjadi glukosa, menyebabkan glukosa untuk masuk kedalam darah lebih cepat.

4) Hasilnya, glukosa darah yang naik ke tingkat normal (sekitar $90 \mathrm{mg} / 100 \mathrm{~mL}$ plasma darah yang).

5) Peningkatan dalam glukosa darah di atas batas normal menghambat pelepasan GHRH.

6) Hiperglikemia, suatu konsentrasi glukosa darah yang normal tinggi, menstimulasi hipotalamus untuk mensekresikan GHIH (sementara menghambat sekresi GHRH).

7) Ketika sampai di hipofisis anterior di dalam darah portal, GHIH menghambat sekresi growth hormone manusia dengan somatotrophs.

8) Sebuah rendahnya human growth hormone dan IGFs memperlambat pemecahan glikogen dalam hati, dan glukosa dirilis ke dalam darah lebih lambat.

9) Glukosa darah turun ke tingkat normal.

10) Penurunan glukosa darah yang di bawah tingkat normal (hipoglikemia) menghambat pelepasan GHIH.

Rangsangan lain yang meningkatkan sekresi human growth hormone termasuk penurunan fatty acids dan peningkatan asam amino dalam darah; tidur yang mendalam (tahap 3 dan 4 non-rapid eye movement sleep); peningkatan aktivitas dari divisi simpatik dari sistem saraf otonom, seperti yang mungkin terjadi pada stres atau latihan fisik yang kuat; dan hormon lainnya, termasuk glukagon, estrogen, kortisol, dan insulin. Faktor-faktor yang menghambat sekresi human growth hormone peningkatan kadar fatty acids dan penurunan kadar asam amino dalam darah; rapit sleep eye movement; kekurangan emosional; obesitas; rendahnya tingkat hormon tiroid; dan human growth hormone itu sendiri (melalui umpan balik negatif). Growth hormon inhibisi hormon (GHIH), alternatif dikenal sebagai somatostatin, juga menghambat sekresi human growth hormone.

\section{Thyroid-Stimulating Hormone}

Thyroid-stimulating hormone (TSH) menstimulasi sintesis dan sekresi dua hormon tiroid, triiodothyronine (T3) dan thyroxine (T4), keduanya diproduksi oleh kelenjar tiroid. Thyrotropin-releasing hormone (TRH) dari hipotalamus mengontrol sekresi TSH. Pelepasan TRH kemudian bergantung pada kadar T3 dan T4; tingginya tingkat T3 dan T4 menghambat sekresi TRH melalui umpan balik negatif.

\section{Follicle-Stimulating Hormone}

Pada wanita, ovarium merupakan target untuk follicle-stimulating hormone (FSH). Setiap bulan FSH memulai pengembangan beberapa folikel ovarium, pengaturan saclike sel sekretori yang mengelilingi oosit berkembang. FSH juga menstimulasi sel-sel folikel untuk mensekresikan estrogen (hormon seks wanita). Pada laki-laki, FSH menstimulasi produksi sperma di testis. Gonadotropinreleasing hormone $(\mathrm{GnRH})$ dari hipotalamus menstimulasi pelepasan FSH. Pelepasan GnRH dan FSH ditekan oleh estrogen pada wanita dan testosteron oleh 
(prinsip hormon seks pria) pada laki-laki melalui sistem umpan balik negatif. Tidak ada gonadotropin inhibisi hormone.

\section{luteinizing Hormone}

Pada wanita, hormone luteinizing (LH) memicu ovulasi, pelepasan oosit sekunder (ovum di masa depan) oleh ovarium. LH menstimulasi pembentukan korpus luteum (struktur terbentuk setelah ovulasi) di ovarium dan sekresi progesteron (hormon seks wanita lain) oleh korpus luteum. Bersama-sama, FSH dan LH juga menstimulasi sekresi estrogen oleh sel ovarium. Estrogen dan progesteron mempersiapkan rahim untuk implantasi dari ovum yang dibuahi dan membantu mempersiapkan kelenjar susu untuk sekresi susu. Pada laki-laki, LH menstimulasi sel-sel dalam testis untuk mensekresikan testosteron. Sekresi $\mathrm{LH}$, seperti itu dari $\mathrm{FSH}$, dikendalikan oleh hormone gonadotropin-releasing hormone $(\mathrm{GnRH})$.

\section{Prolaktin}

Prolaktin (PRL), bersama-sama pada hormon lain, inisiasi dan mempertahankan produksi ASI oleh kelenjar payudara. Dengan sendirinya, prolaktin hanya memiliki efek yang lemah. Hanya setelah kelenjar payudara telah prima oleh estrogen, progesteron, glukokortikoid, human growth hormone, tiroksin, dan insulin, dimana memberi efek permisif, apakah PRL menghasilkan produksi ASI. Ejeksi susu dari kelenjar payudara tergantung pada hormon oksitosin, dimana dirilis dari hipofisis posterior. Bersama-sama, produksi ASI dan ejeksi merupakan laktasi.

Hipotalamus mengeluarkan kedua hormon inhibitor dan rangsang yang mengatur sekresi prolaktin. Pada wanita, hormone prolactininhibiting (PIH), yang merupakan dopamin, menghambat pelepasan prolaktin dari hipofisis anterior sering kali. Setiap bulan, sebelum menstruasi dimulai, sekresi PIH berkurang dan tingkat darah prolaktin meningkat, namun belum cukup untuk menstimulasi produksi ASI. Nyeri payudara sebelum menstruasi dapat disebabkan oleh prolaktin tinggi.

Sebagaimana dalam siklus menstruasi berulang kembali, PIH ini kembali disekresi dan tingkat prolaktin menurun. Selama kehamilan, tingkat prolaktin naik, distimulasi oleh prolaktin-releasing hormone (PRH) oleh hipotalamus. Mengisap tindakan seorang bayi menyusui menyebabkan penurunan sekresi PIH dari hipotalamus.

Fungsi prolaktin ini tidak diketahui pada laki-laki, namun hipersekresi yang menyebabkan disfungsi ereksi (impotensi, ketidakmampuan untuk memiliki ereksi penis). Pada wanita, hipersekresi prolaktin menyebabkan galaktorea (laktasi tidak pantas) dan amenore (tidak adanya siklus menstruasi).

\section{Hormon adrenokortikotropik}

Corticotrophs mensekresikan hormone utamanya adrenokortikotropik (ACTH). ACTH mengontrol produksi dan sekresi kortisol dan glukokortikoid lainnya oleh korteks (bagian terluar) dari kelenjar adrenal. Corticotropin-releasing hormone $(\mathrm{CRH})$ oleh hipotalamus menstimulasi sekresi $\mathrm{ACTH}$ oleh corticotrophs. 
Rangsangan stres yang berhubungan, seperti misalnya glukosa darah rendah atau trauma fisik, dan interleukin-1, zat yang diproduksi oleh makrofag, juga menstimulasi pelepasan ACTH. Glukokortikoid menghambat CRH dan ACTH release melalui umpan balik negatif.

\section{Melanosit-Stimulating Hormone}

Melanosit-stimulating hormone (MSH) meningkatkan pigmentasi kulit amfibi dengan merangsang penyebaran butiran melanin di melanosit. Peran yang tepat dalam manusia tidak diketahui, namun keberadaan reseptor MSH dalam otak mempengaruhi aktivitas otak. Ada sedikit beredar MSH pada manusia. Namun, pemberian terus MSH selama beberapa hari tidak menghasilkan suatu kulit gelap. Tingkat berlebihan corticotropin-releasing hormone (CRH) dapat menstimulasi release $\mathrm{MSH}$; dopamin menghambat pelepasan $\mathrm{MSH}$.

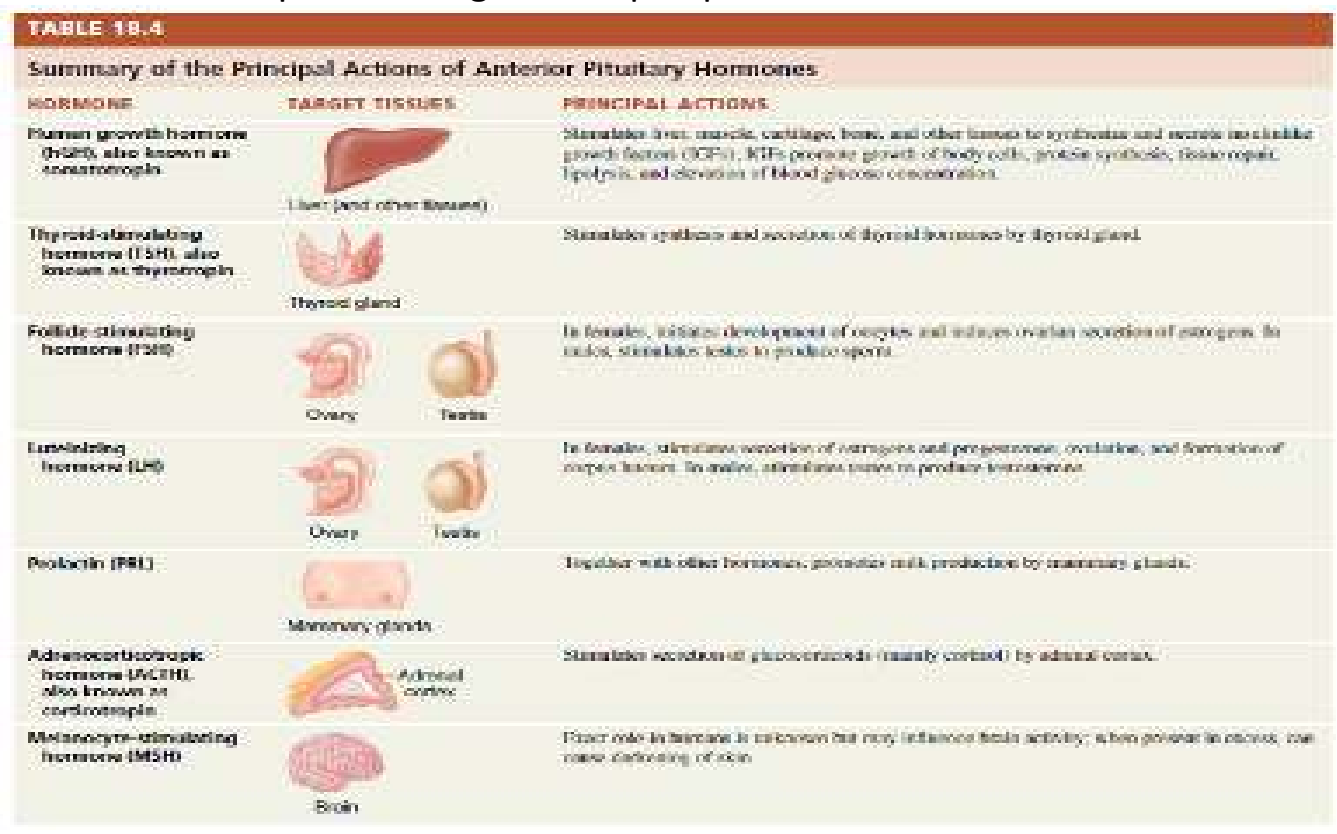

\section{b. Hipofisis Posterior}

Walaupun hipofisis posterior atau neurohypophysis tidak mensintesa hormon, hal itu menyimpan dan melepaskan dua hormon. Ini terdiri atas akson dan terminal akson lebih dari 10.000 sel neurosecretory hipotalamus. sel sel neurosecretory berada di paraventrikular dan supraoptik inti hipotalamus; akson mereka membentuk saluran hypothalamohypophyseal.

Saluran ini dimulai di hipotalamus dan berakhir di dekat kapiler darah di hipofisis posterior. Para badan sel saraf baik dari paraventrikular dan inti supraoptik mensintesa hormon oksitosin dan hormone antidiuretik (ADH), disebut juga vasopressin. Terminal akson di hipofisis posterior berhubungan dengan neuroglia khusus yang disebut pituicytes. Sel-sel ini memiliki peran pendukung mirip dengan astrosit.

Setelah produksi mereka di badan sel sel neurosecretory, oksitosin dan hormon antidiuretik dikemas ke dalam vesikel sekretorik, dimana bergerak dengan 
transportasi aksonal cepat ke terminal akson di hipofisis posterior, keberadaan mereka disimpan sampai impuls saraf memicu eksositosis dan pelepasan hormon.

Darah disuplai ke hipofisis posterior oleh arteri hypophyseal inferior, arteri ini cabang dari arteri karotis interna. Dalam hipofisis posterior, arteri hypophyseal inferior mengalir menuju pleksus kapiler dalam proses infundibular, jaringan kapiler yang mendapat sekresi oksitosin dan hormon antidiuretik. Dari pleksus ini, hormon masuk ke pembuluh darah hypophyseal posterior untuk distribusi menuju sel-sel dalam jaringan target.

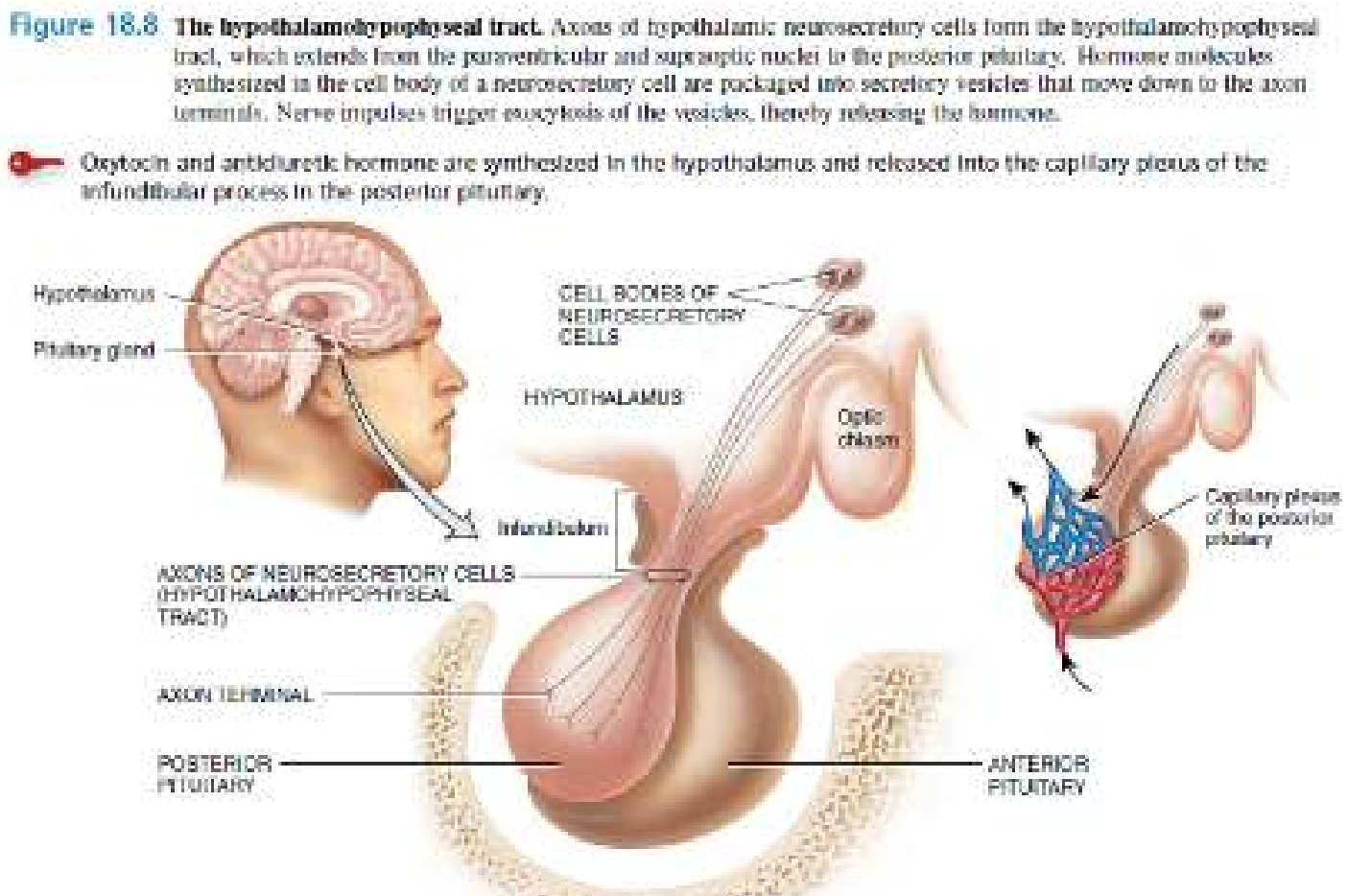

\section{Pengendalian Sekresi oleh posterior hipofisis}

Oksitosin Pada saat dan setelah persalinan seorang bayi, oksitosin mempengaruhi dua jaringan target: rahim ibu dan payudara. Saat persalinan, peregangan leher rahim rahim merangsang pelepasan oksitosin dimana, pada gilirannya akan, dapat meningkatkan kontraksi sel otot polos pada dinding rahim; setelah persalinan, merangsang susu ejeksi ("letdown") dari kelenjar payudara sebagai respons terhadap stimulus mekanik diberikan oleh bayi suckling. Fungsi oksitosin pada laki-laki dan pada wanita tidak hamil belum jelas. Percobaan pada hewan telah menyarankan bahwa ia memiliki tindakan dalam dalam otak yang mendorong perilaku perawatan orangtua terhadap anaknya anak. Ini mungkin juga bertanggung jawab, sebagian, untuk perasaan kenikmatan seksual saat dan setelah hubungan seksual.

\section{Antidiuretik Hormon}

Sesuai dengan namanya, sebuah hormon antidiuretik adalah zat yang menurunkan produksi urine. ADH menyebabkan ginjal untuk mengembalikan lebih banyak air ke dalam darah, sehingga menurunkan volume urine. Dengan tidak adanya $A D H$, urin meningkat lebih dari sepuluh kali lipat, dari yang normal 1 sampai 2 liter menjadi sekitar 20 liter per hari. Minum alkohol sering menyebabkan sering buang air kecil dan 
berlebihan karena alkohol menghambat sekresi ADH. ADH juga menyebabkan berkurangnya hilangnya air melalui keringat dan menyebabkan penyempitan arteriol, yang meningkatkan tekanan darah. hormone ini ini lain nama, vasopressin, menggambarkan efek terhadap tekanan darah.

Banyaknya ADH disekresi bervariasi tergantung tekanan osmotik darah dan volume darah, berikut penjelasannya:

Figure 18.9 Regulation of secretion and actions of antidiuretic hormone (ADH).

$\mathrm{ADH}$ acts to retain body water and increase blood pressure.

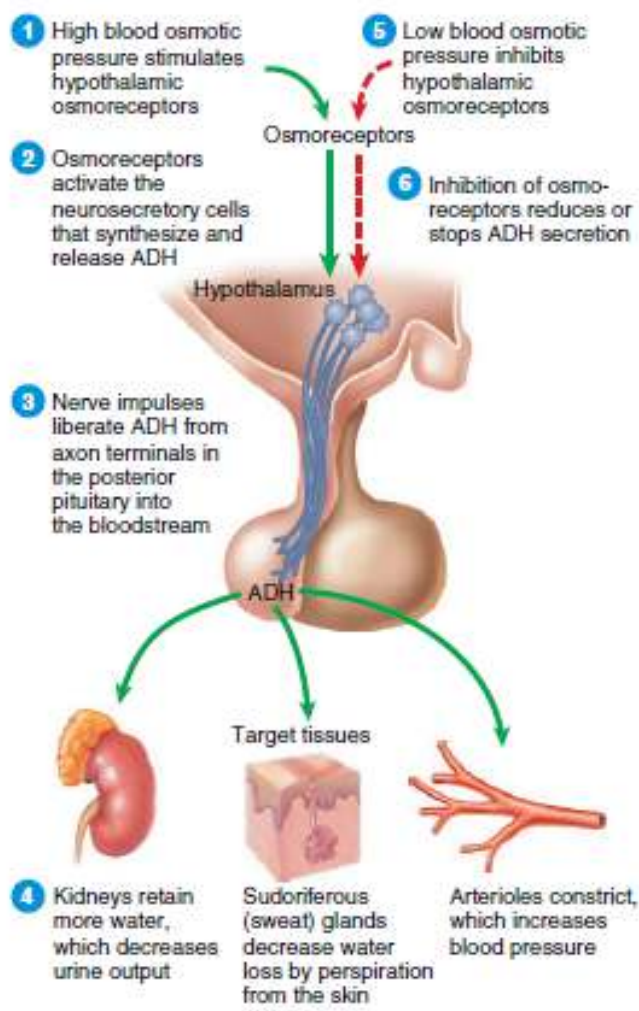

(1) Tekanan osmotik darah tinggi (atau penurunan volume darah) -karena dehidrasi atau penurunan volume darah karena perdarahan, diare, atau berlebihan berkeringat-menstimulasi osmoreseptor, neuron di hipotalamus yang memonitor tekanan osmotik darah yang. Tekanan osmotik darah mengaktifkan osmoreseptor secara langsung; mereka juga menerima input rangsang dari daerah otak lainnya bila volume darah menurun.

(2) Osmoreseptor mengaktifkan sel-sel neurosecretory hipotalamus yang mensintesis dan melepaskan ADH

(3) Bila sel-sel neurosecretory menerima input rangsang dari osmoreseptor, mereka menghasilkan impuls saraf yang menimbulkan eksositosis $A D H$ yang mengandung vesikel dari terminal akson mereka di hipofisis posterior. Hal ini melepaskan ADH, dimana berdifusi ke kapiler darah hipofisis posterior.

(4) Darah membawa ADH tiga jaringan target: ginjal, sudoriferous (keringat) kelenjar, dan otot polos di dinding pembuluh darah. Ginjal merespon dengan mempertahankan lebih banyak air, yang akan menurunkan produksi urine. Kegiatan Sekretori kelenjar keringat menurun, yang menurunkan tingkat 
kehilangan air dengan keringat dari kulit. Otot polos di dinding arteriol (arteri kecil) kontrak sebagai respons terhadap tingginya tingkat $A D H$, dimana konstriksi (menyempit) lumen pembuluh darah tersebut dan meningkatkan tekanan darah.

(5) Tekanan osmotik darah rendah (atau volume darah meningkat) dapat menghambat osmoreseptor.

(6) Inhibisi osmoreseptor menurunkan atau menghentikan sekresi ADH. Ginjal kemudian menahan air kurang dengan cara membentuk lebih besar volume dari urin, aktivitas sekresi kelenjar keringat meningkat, dan arteriol melebar. Volume darah dan tekanan osmotik cairan tubuh kembali normal

Sekresi ADH juga dapat diubah dengan cara lain. Nyeri, stres, trauma, kecemasan, asetilkolin, nikotin, dan obat-obatan seperti morfin, obat penenang, dan beberapa anestesi menstimulasi sekresi ADH. Efek dehidrasi alkohol, dimana telah disebutkan, dapat menyebabkan baik haus dan sakit kepala khas mabuk. Hyposecretion ADH atau reseptor $\mathrm{ADH}$ nonfungsional menyebabkan diabetes insipidius.

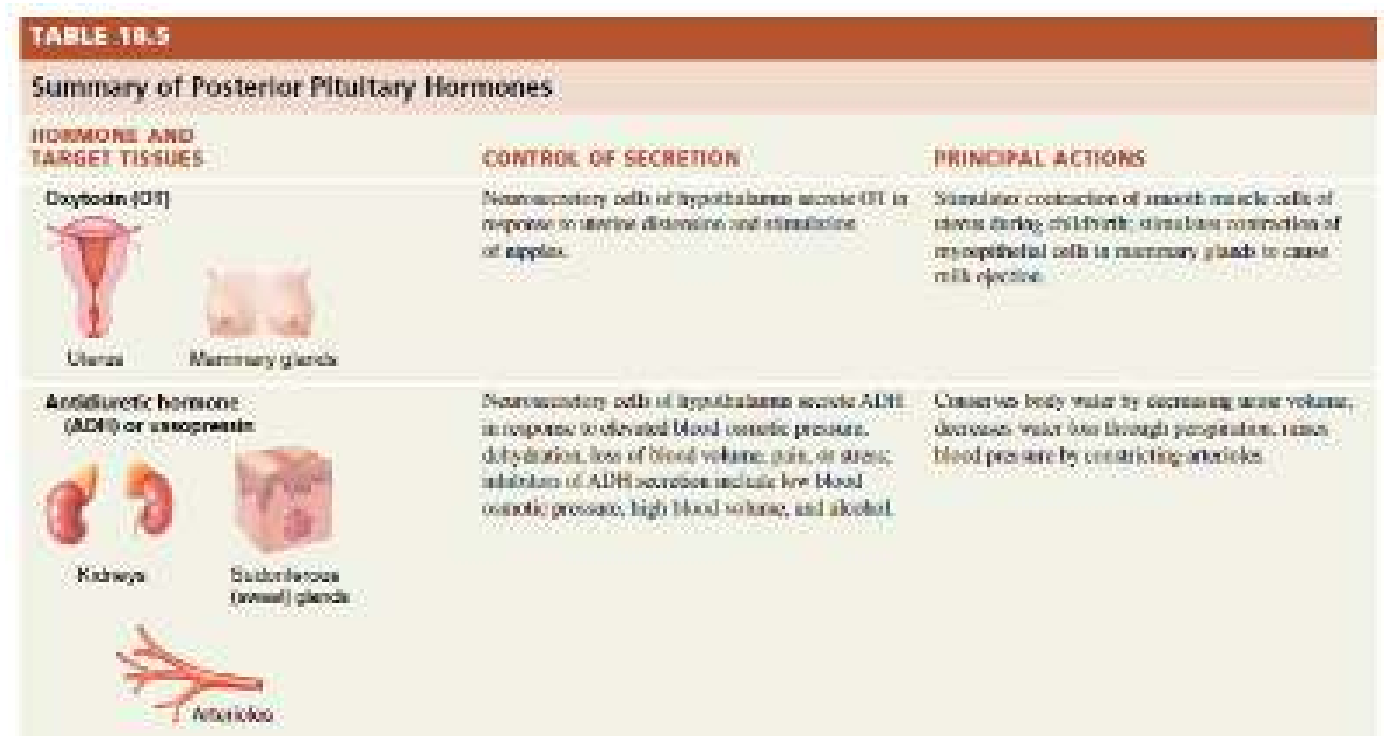

\section{Kelenjar thyroid}

Kelenjar tiroid berbentuk kupu-kupu berada di inferior laring (kotak suara). Terdiri dari lobus lateral kanan dan kiri, terletak di kedua sisi trakea, yang dihubungkan oleh sebuah isthimus anterior ke trakea (Gambar 18.10a). Sekitar 50\% dari kelenjar tiroid memiliki tiga lobus kecil, yang disebut lobus piramidal. Memanjang superior dari isthmus. Massa normal tiroid adalah sekitar $30 \mathrm{~g}(1 \mathrm{oz})$.

Kantung berbentuk bola mikroskopis disebut folikel tiroid membentuk kebanyakan kelenjar tiroid. Dinding setiap folikel utamanya terdiri dari sel yang disebut sel folikel, yang sebagian besar memperluas ke lumen (ruang internal) dari folikel. Sebuah membran basal mengelilingi setiap folikel. Bila sel-sel folikel yang tidak aktif, berbentuk cuboidal Rendah hingga skuamosa, tetapi di bawah pengaruh TSH mereka menjadi aktif dalam sekresi dan dalam bentuk yang mulai dari cuboidal ke kolumnar rendah. Sel-sel folikel menghasilkan dua hormon: tiroksin, yang juga disebut tetraiodothyronine (T4) karena mengandung empat atom yodium, dan triiodothyronine (T3), yang berisi tiga atom yodium. T3 dan T4 bersama-sama juga dikenal sebagai hormon tiroid. 
Beberapa sel yang disebut sel parafollicular atau sel C terletak di antara folikel. Mereka menghasilkan hormon kalsitonin (CT), yang membantu mengatur homeostasis kalsium.

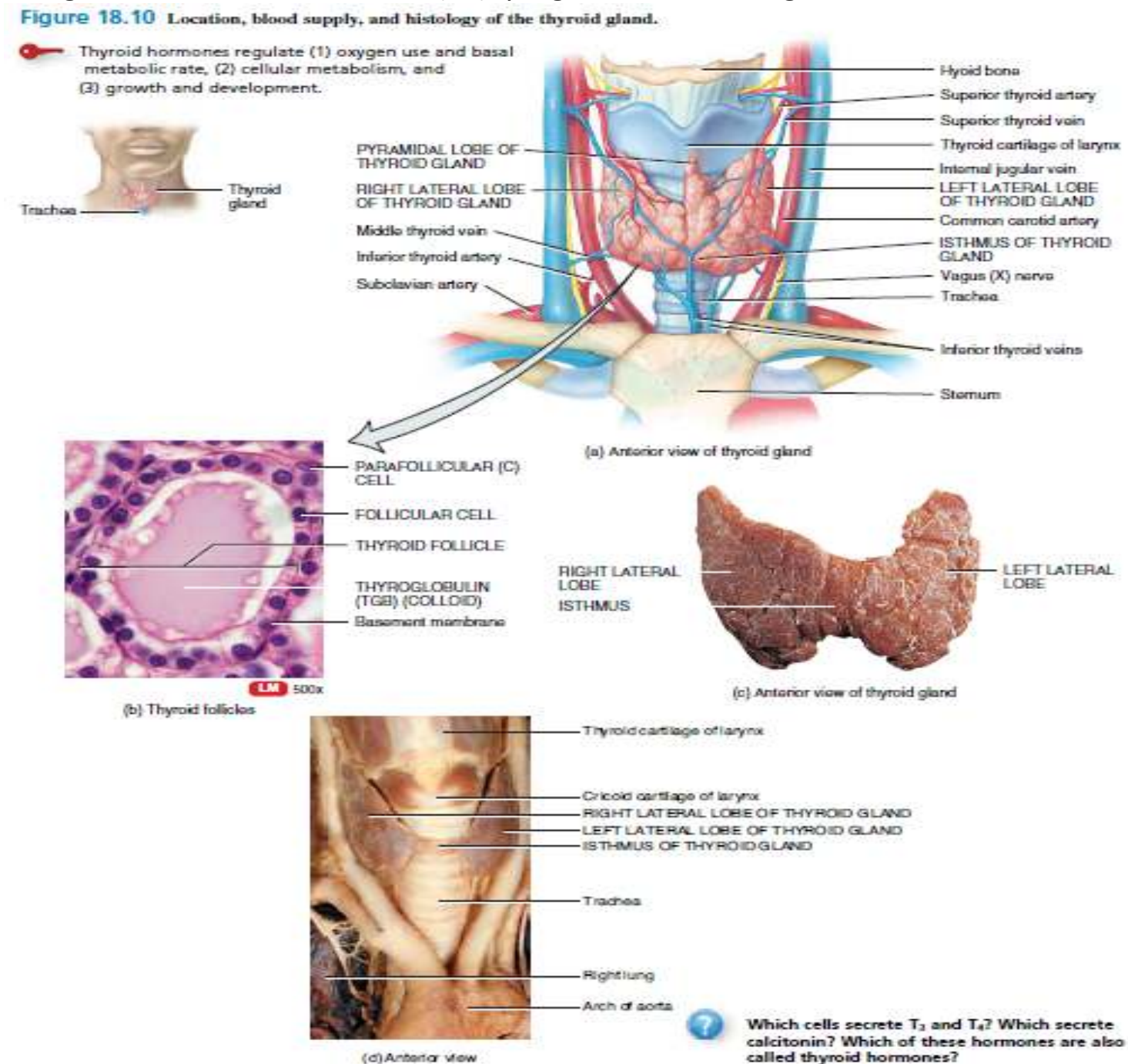

\section{Susunan, Penyimpanan, dan Pelepasan Tiroid Hormon}

Kelenjar tiroid adalah satu-satunya kelenjar endokrin yang menyimpan produk sekretori dalam besar jumlah-biasanya sekitar persediaan 100-hari. Sintesis dan sekresi T3 dan T4 terjadi sebagai berikut:

1. Trapping iodida. Tiroid folikel sel trap iodida ion dengan aktif mengangkutnya dari darah ke sitosol. Hasilnya, kelenjar tiroid secara normal mengandung sebagian besar iodida dalam tubuh.

2. Sintesis tiroglobulin. Meskipun sel-sel folikel yang Trapping, mereka juga sintesis tiroglobulin (TGB), suatu glikoprotein besar yang dihasilkan dalam retikulum endoplasma, yang dimodifikasi di kompleks Golgi, dan dikemas dalam vesikel sekretorik. Vesikel kemudian menjalani eksositosis, yang melepaskan TGB ke dalam lumen folikel. 


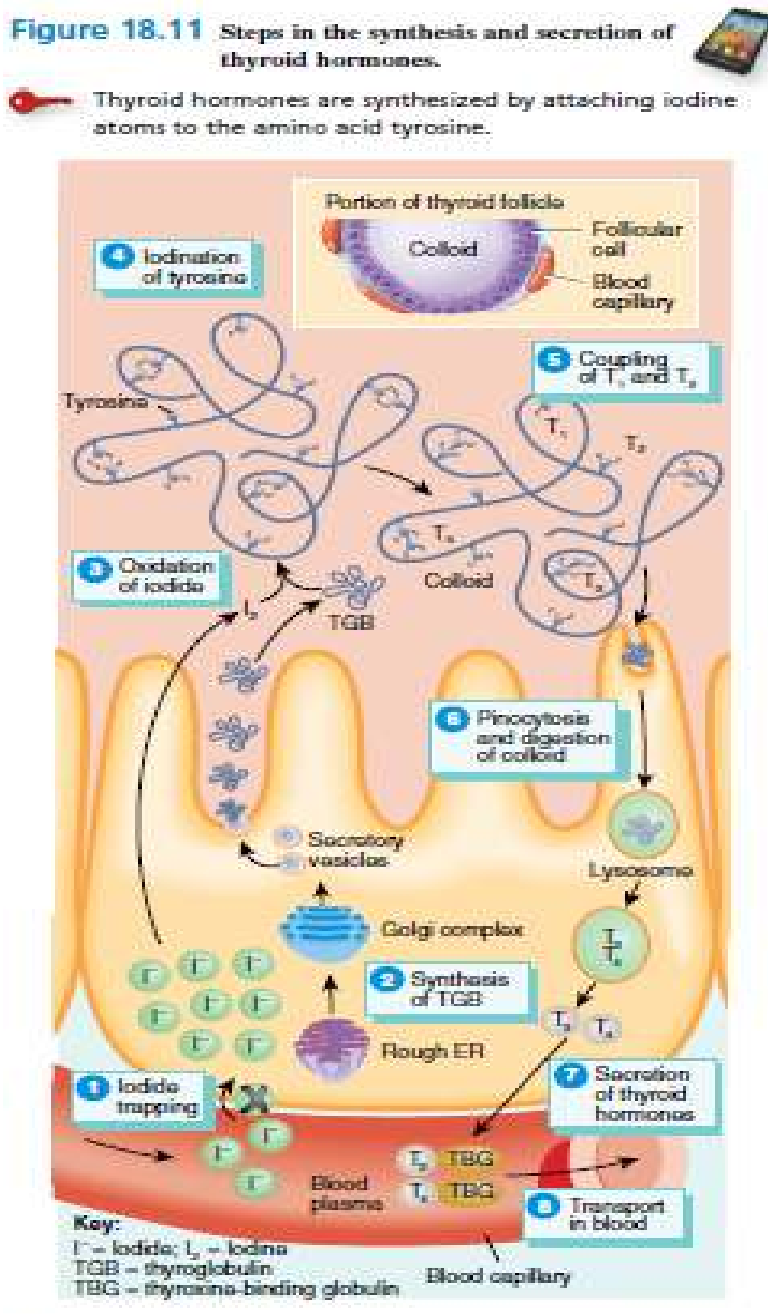

(3)Oksidasi iodida. Beberapa asam amino di TGB adalah tyrosines yang akan menjadi iodinasi. Namun, ion iodida bermuatan negatif tidak dapat mengikat tirosin sampai mereka mengalami oksidasi (pengangkatan elektron) ke yodium: Sebagaimana ion iodida sedang teroksidasi, mereka melewati membran ke dalam lumen folikel.

(4) Iodinasi tirosin. Sebagaimana molekul yodium (12) bentuk, mereka bereaksi dengan tyrosines yang merupakan bagian dari molekul tiroglobulin. Pengikatan satu hasil yodium atom monoiodotyrosine (T1), dan iodinasi kedua menghasilkan Diiodothyrosine (T2). TGB dengan atom yodium menempel, bahan lengket yang terakumulasi dan disimpan dalam lumen folikel tiroid, yang disebut koloid.

(5) Coupling T1 dan T2. Pada saat tahap terakhir dalam sintesis hormon tiroid, dua molekul T2 bergabung untuk membentuk T4, atau satu T1 dan T2 satu bergabung untuk membentuk T3.

(6) Pinositosis dan pencernaan koloid. Butiran koloid masuk kembali ke sel-sel folikel dengan pinositosis dan bergabung dengan lisosom. Enzim pencernaan dalam lisosom memecah TGB, membelah dari molekul T3 dan T4.

(7) Sekresi hormon tiroid. Karena T3 dan T4 yang larut lemak, mereka menyebar melalui membran plasma ke dalam cairan interstitial dan kemudian ke dalam darah. T4 biasanya disekresikan dalam jumlah yang lebih besar dari T3, tetapi T3 adalah beberapa kali lebih kuat. Selain itu, setelah T4 memasuki sel tubuh, sebagian besar diubah menjadi T3 oleh penghapusan satu yodium.

(8) Transportasi dalam darah. Lebih dari 99\% baik dari T3 dan T4 menggabungkan dengan protein transport dalam darah, utamanya thyroxine-binding globulin (TBG).

\section{Aksi Tiroid Hormon}

Karena tubuh sel-sel memiliki reseptor untuk hormon tiroid, T3 dan T4 menggunakan efeknya ke seluruh tubuh.

1) Hormon tiroid meningkatkan metabolisme basal rate (BMR), laju pemakaian oksigen dalam kondisi standar atau basal (terjaga, saat istirahat, dan puasa), dengan merangsang penggunaan oksigen seluler untuk menghasilkan ATP. Ketika meningkat basal metabolic rate, metabolisme sel karbohidrat, lipid, dan protein meningkat. 
2) Efek utama kedua hormon tiroid adalah untuk menstimulasi sintesis tambahan pompa natrium-kalium. dimana menggunakan jumlah besar ATP untuk senantiasa mengeluarkan ion natrium dari sitosol ke dalam ion cairan dan kalium ekstraseluler dari cairan ekstraseluler ke dalam sitosol. Seperti sel-sel produksi dan lebih banyak menggunakan ATP, banyak panas yang dilepaskan, dan suhu tubuh meningkat. Fenomena ini disebut efek calorigenic. Dengan cara ini, hormon tiroid memainkan peran penting dalam pemeliharaan suhu tubuh normal. Mamalia yang normal dapat bertahan hidup dalam suhu beku, namun mereka yang memiliki tiroid kelenjar telah dilepaskan tidak bisa.

3) Dalam regulasi metabolisme, hormon tiroid menstimulasi sintesis protein dan meningkatkan penggunaan glukosa dan asam lemak untuk produksi ATP. Mereka juga meningkatkan lipolisis dan meningkatkan ekskresi kolesterol, sehingga mengurangi kadar kolesterol darah.

4) Hormon tiroid meningkatkan beberapa tindakan katekolamin (norepinefrin dan epinefrin) karena mereka upregulate reseptor beta. Untuk alasan ini, gejala hipertiroid meliputi peningkatan heart rate, denyut jantung lebih kuat, dan peningkatan tekanan darah.

5) Sama dengan growth hormone manusia dan insulin, hormon tiroid percepatan pertumbuhan tubuh, terutama pertumbuhan sistem saraf dan tulang. Kekurangan hormon tiroid selama perkembangan janin, bayi, atau anak usia menyebabkan keterbelakangan mental yang berat dan pertumbuhan tulang terhambat.

\section{Kontrol Sekresi Tiroid Hormon}

Thyrotropin-releasing hormone (TRH) dari hipotalamus dan thyroid-stimulating hormone (TSH) dari hipofisis anterior menstimulasi sintesis dan pelepasan hormon tiroid. Seperti keterangan dibawah:

1) Tingkat darah rendah $T 3$ dan $T 4$ atau tingkat metabolisme yang rendah menstimulasi hipotalamus untuk mensekresikan TRH.

2) TRH memasuki vena Portal hypophyseal dan mengalir ke hipofisis anterior, keberadaan merangsang thyrotrophs untuk mensekresikan TSH.

3) TSH menstimulasi hampir semua aspek aktivitas sel folikel tiroid, termasuk iodida Trapping (1 Gambar), sintesis hormone dan sekresi (2 dan 7 pada Gambar), dan pertumbuhan sel-sel folikel.

4) Sel-sel folikel tiroid release T3 dan T4 ke dalam darah sampai kembali tingkat metabolisme normal.

5) Tingkat yang lebih tinggi dari T3 menghambat pelepasan TRH dan TSH (inhibisi umpan balik negatif).

Kondisi yang meningkatkan ATP permintaan lingkungan yang dingin, hipoglikemia, ketinggian, dan kehamilan-juga meningkatkan sekresi hormon tiroid. 


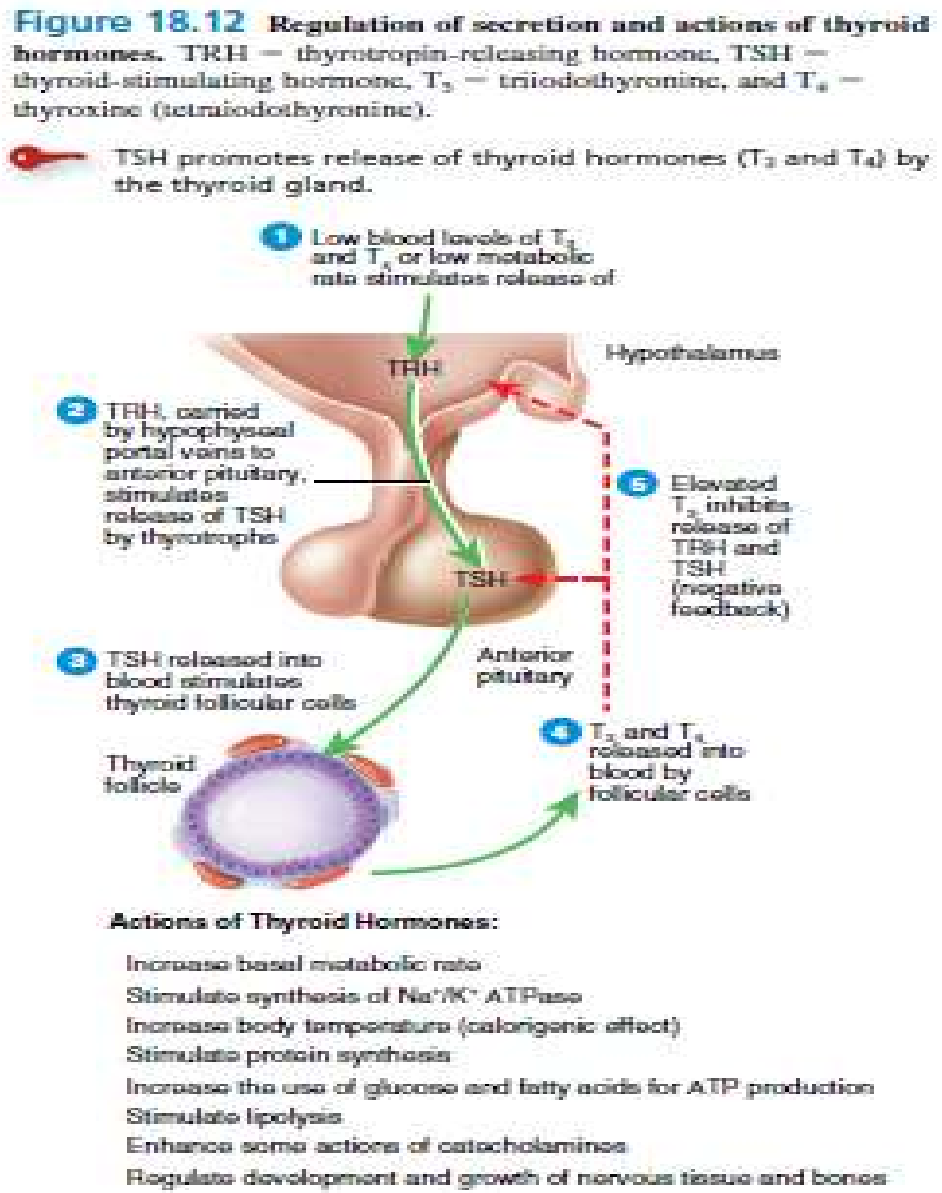

\section{calcitonin}

Hormon yang diproduksi oleh sel-sel parafollicular dari kelenjar tiroid adalah kalsitonin (CT). CT dapat menurunkan kadar kalsium dalam darah dengan menghambat aksi osteoklas, sel-sel yang memecah tulang matriks ekstraselular. Sekresi CT dikendalikan oleh sistem umpan balik negatif.

\section{TABLE 18.6}

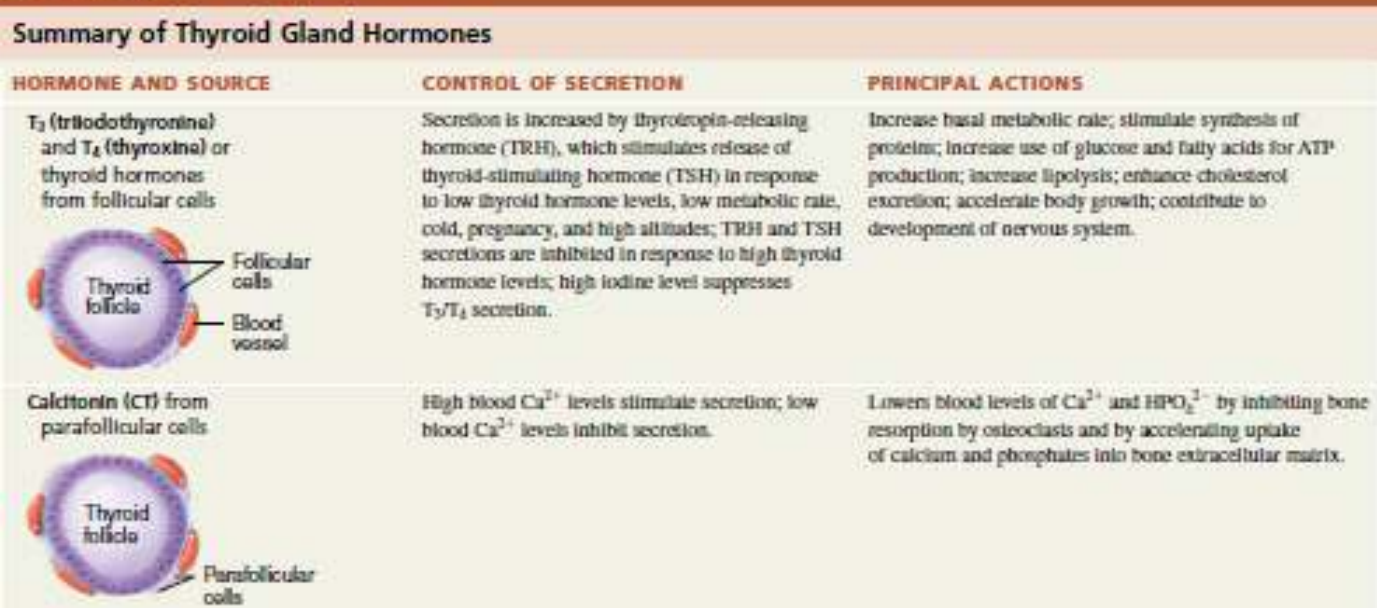

Ketika tingkat darah tinggi, kalsitonin menurunkan jumlah kalsium darah dan fosfat dengan menghambat resorpsi tulang (pemecahan tulang matriks ekstraselular) oleh osteoklas dan dengan mempercepat uptake kalsium dan fosfat ke dalam tulang matriks ekstraselular. Miacalcin, ekstrak kalsitonin yang berasal 
dari salmon yang 10 kali lebih kuat dari kalsitonin manusia, diresepkan untuk mengobati osteoporosis.

\section{Kelenjar Paratiroid}

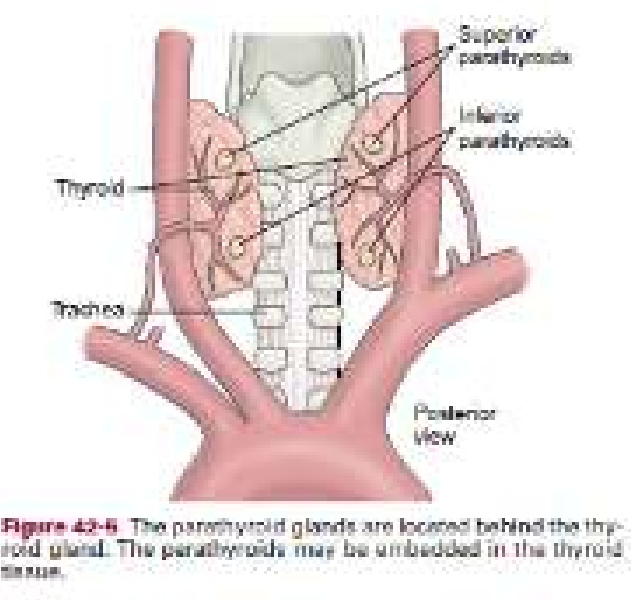

Kelenjar paratiroid (secara normal empat) yang terletak di leher dan melekat pada lobus lateral posterior dari kelenjar tiroid. Masing-masing memiliki massa sekitar $40 \mathrm{mg}(0,04 \mathrm{~g})$. Secara mikroskopis, kelenjar paratiroid mengandung dua jenis sel epitel (Gambar 18.13b, c). Semakin banyak sel yang disebut sel chief atau sel utama, menghasilkan hormon paratiroid (PTH), juga disebut parathormon. Fungsi dari jenis lain sel, yang disebut sel oxyphil, belum diketahui pada kelenjar paratiroid normal. Namun, kehadirannya jelas membantu untuk mengidentifikasi kelenjar paratiroid secara

histologis karena karakteristik pewarnaan yang unik. Selain itu, dalam kanker kelenjar paratiroid, oxyphil sel mensekresi kelebihan PTH.

\section{Paratiroid Hormon (PTH)}

Hormon paratiroid adalah regulator utama dari kadar kalsium $\left(\mathrm{Ca}^{2+}\right)$, magnesium $\left(\mathrm{Mg}^{2+}\right)$, dan ion fosfat $\left(\mathrm{HPO}_{4}{ }^{2-}\right)$ dalam darah. Aksi spesifik PTH adalah untuk meningkatkan jumlah dan aktivitas osteoclasts. Akibatnya ditinggikan resorpsi tulang, yang melepas kalsium ion dan fosfat ke dalam darah. PTH juga berperan pada ginjal. Pertama, memperlambat tingkat di mana $\mathrm{Ca}^{2+}$ dan $\mathrm{Mg}^{2+}$ hilang dalam darah ke dalam urin. Kedua, meningkatkan hilangnya $\mathrm{HPO}_{4}{ }^{2-}$ dari dalam darah ke dalam urin. Karena lebih $\mathrm{HPO}_{4}{ }^{2-}$ hilang dalam urin daripada yang diperoleh dari tulang, PTH menurunkan HPO4 dalam darah dan meningkatkan tingkat $\mathrm{Ca}^{2+}$ dan $\mathrm{Mg}^{2+}$ dalam darah. Efek ketiga PTH pada ginjal adalah untuk meningkatkan pembentukan hormon calcitriol, bentuk aktif dari vitamin $D$. Calcitriol, juga dikenal sebagai 1,25-dihydroxyvitamin D3, meningkatkan tingkat $\mathrm{Ca}^{2+}$, $\mathrm{HPO}_{4}{ }^{2-}$, dan $\mathrm{Mg}^{2+}$ absorpsi dari saluran pencernaan ke dalam darah. 
Figure 18.13 Location, blood supply, and histology of the purathyroid glands.

- The parathyroid glands, normally four in number, are embedded in the posterior surface of the thyroid gland.
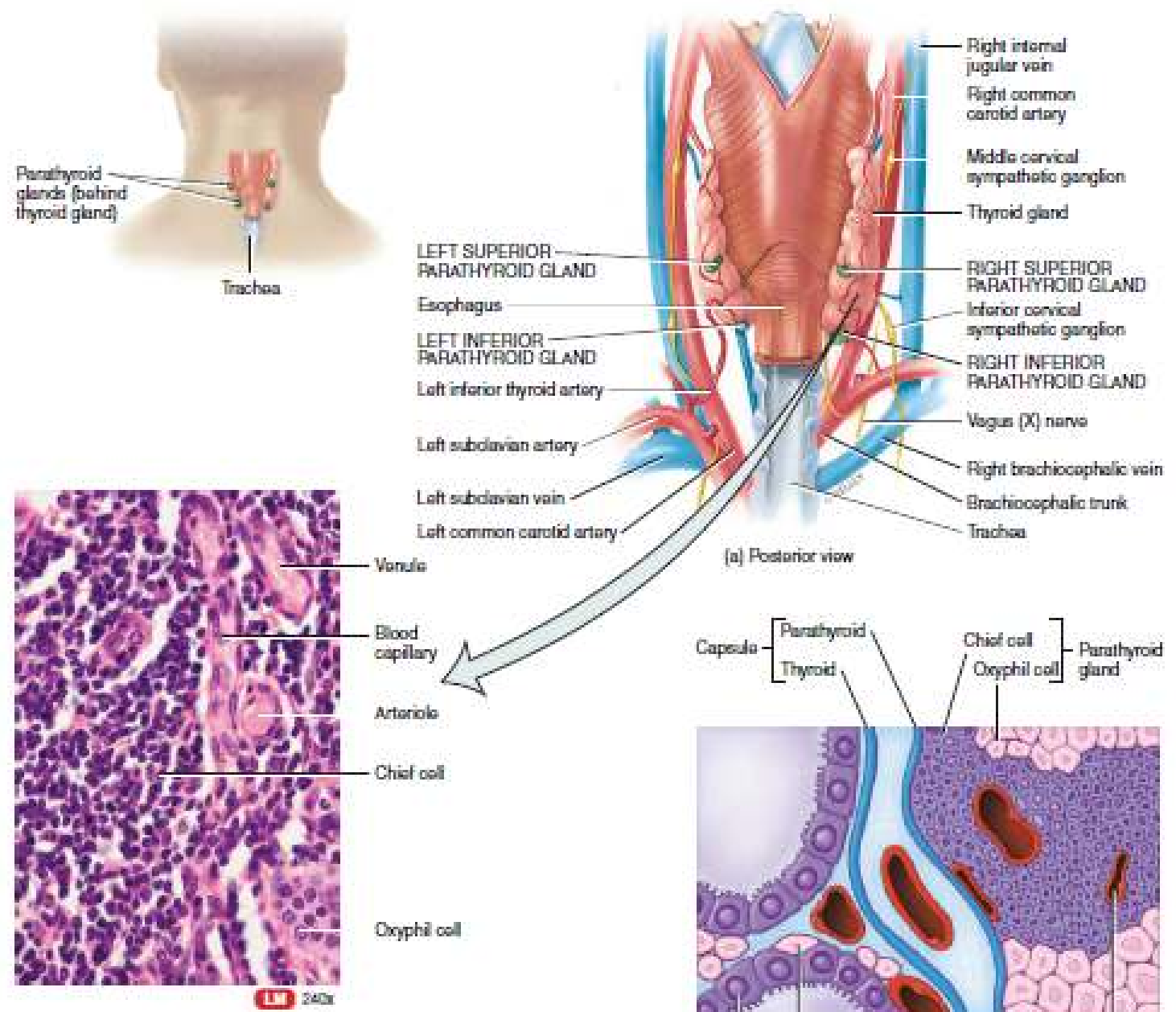

(b) Panathyroid gland
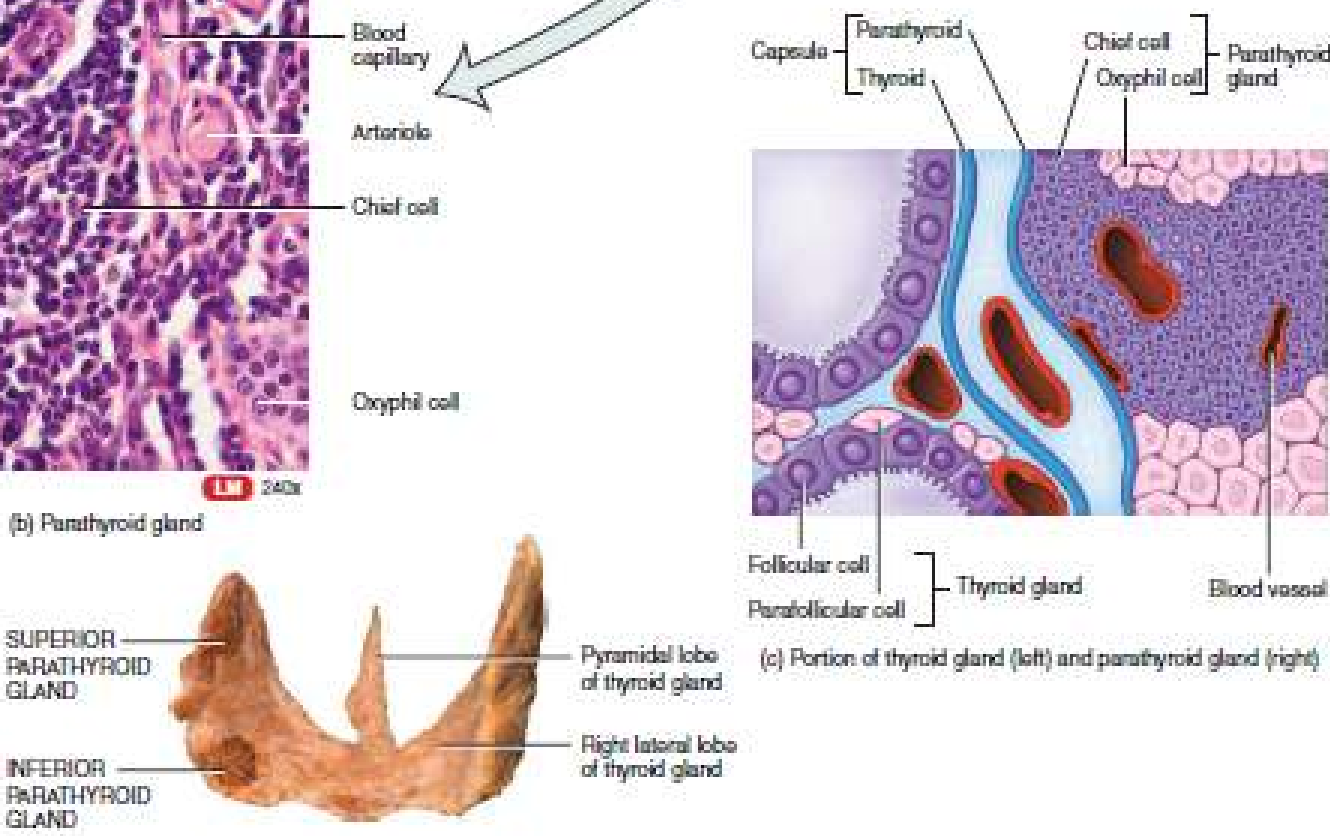

(c) Porticn of thyroid gand (leit) and paratyruid gand (right)

(d) Postorior viow of panuthroid gands 


\section{Pengendalian Sekresi Calcitonin dan paratiroid hormon}

Tingkat kalsium dalam darah secara langsung mengontrol sekresi baik kalsitonin dan hormon paratiroid melalui umpan balik negatif yang tidak melibatkan kelenjar pituitari.

Figure 18.14 The roles of calcitonin (preen arrows), parathyroid hormone (blue arrows), and calcitriol (orange arrows) in calcium homeostasis.

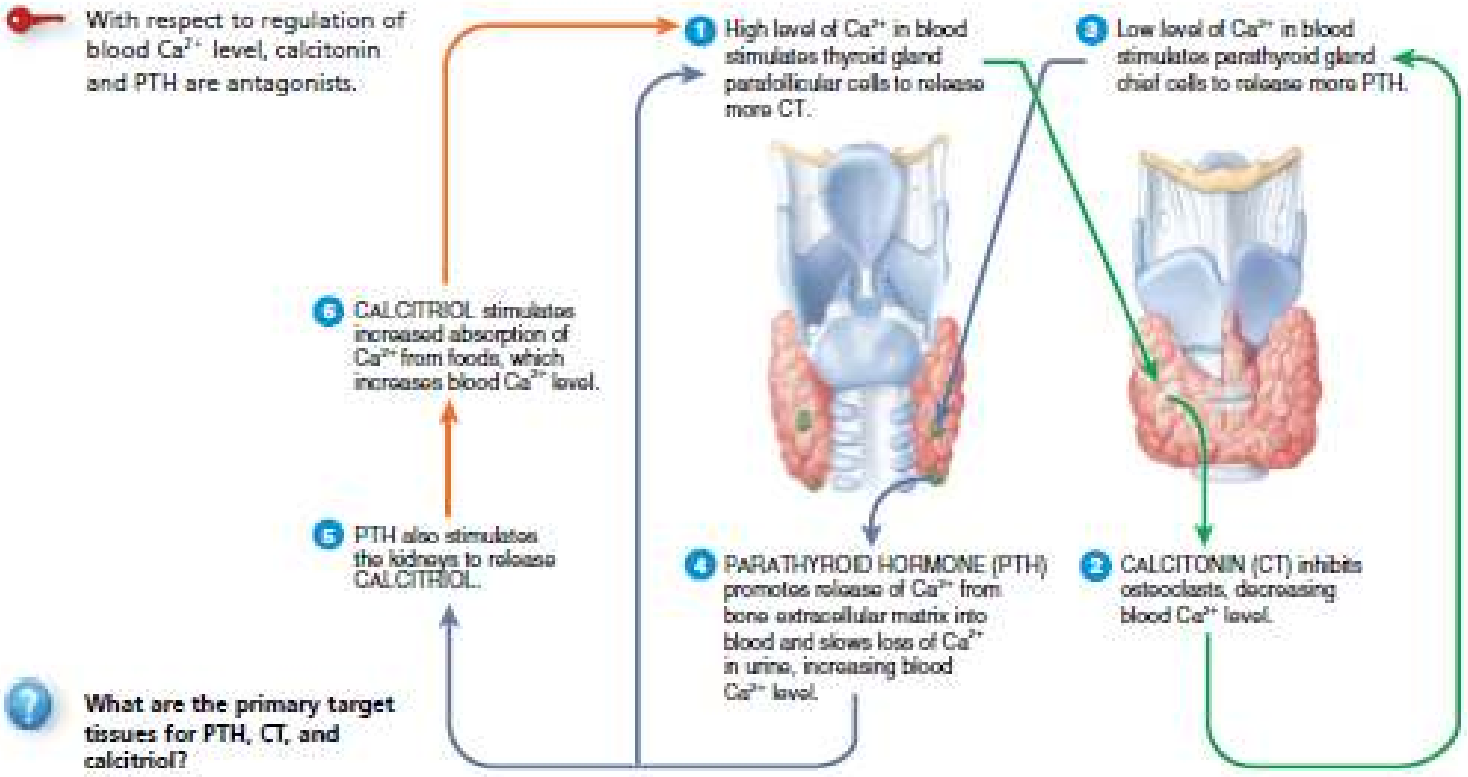

1. Suatu level yang lebih tinggi dari normal ion kalsium dalam darah menstimulasi selsel parafollicular dari kelenjar tiroid untuk melepaskan lebih banyak kalsitonin.

2. Calcitonin menghambat aktivitas osteoklas, sehingga mengurangi tingkat $\mathrm{Ca}^{2+}$ dalam darah.

3. Suatu tingkat $\mathrm{Ca}^{2+}$ yang lebih rendah dari normal dalam darah akan menstimulasi selsel utama kelenjar paratiroid untuk melepaskan lebih banyak PTH.

4. PTH mendorong resorpsi matriks ekstraselular tulang, yang melepas $\mathrm{Ca}^{2+}$ ke dalam darah dan memperlambat hilangnya $\mathrm{Ca}^{2+}$ dalam urin, untuk meningkatkan tingkat darah $\mathrm{Ca}^{2+}$

5. PTH juga merangsang ginjal untuk mensintesis calcitriol, bentuk aktif dari vitamin D.

6. Calcitriol merangsang peningkatan penyerapan $\mathrm{Ca}^{2+}$ yang berasal dari makanan di saluran pencernaan, yang akan membantu meningkatkan tingkat darah $\mathrm{Ca}^{2+}$.

\section{TABLE 18.7}

Summary of Parathyroid Gland Hormone

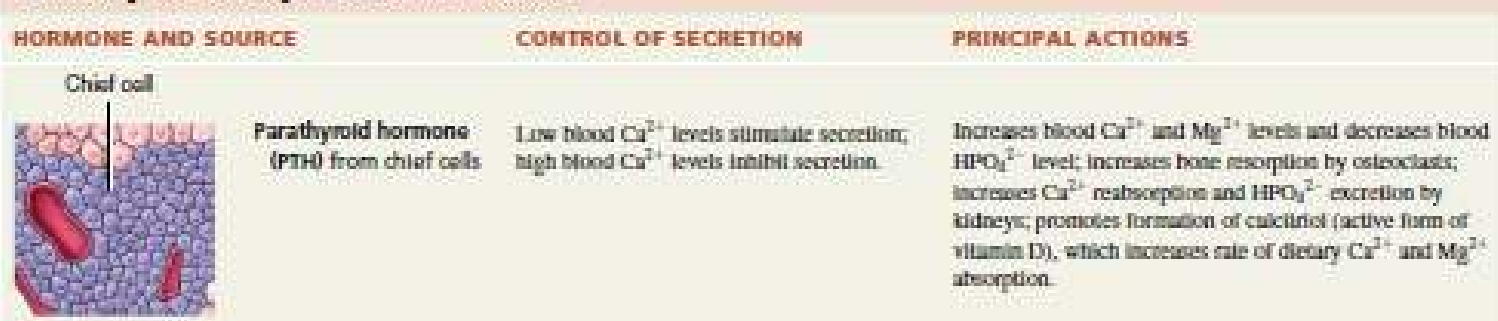




\section{Hormon Adrenal}

Kelenjar adrenal pasangan atau kelenjar suprarenal, salah satunya terletak unggul setiap ginjal di ruang retroperitoneal (Gambar 18.15a), memiliki piramida berbentuk pipih. Dalam orang dewasa, masing-masing kelenjar adrenal adalah 3-5 cm, 2-3 cm lebar, dan sedikit kurang dari $1 \mathrm{~cm}$, dengan massa 3,5-5 g, hanya setengah dari ukuran saat lahir. Selama perkembangan embrio, kelenjar adrenal berdiferensiasi menjadi dua struktural dan fungsional daerah yang berbeda: besar, perifer terletak korteks adrenal, yang terdiri dari $80-90 \%$ dari kelenjar, dan kecil, terletak medula adrenal (Gambar 18.15b). Suatu kapsul jaringan ikat mencakup kelenjar. Kelenjar adrenal, seperti kelenjar tiroid, sangat tervaskularisasi.

Korteks adrenal menghasilkan hormon steroid yang penting bagi kehidupan. Kehilangan lengkap hormon adrenocortical menyebabkan kematian karena dehidrasi dan ketidakseimbangan elektrolit dalam beberapa hari sampai seminggu, kecuali terapi penggantian hormon dimulai segera. Adrenal medulla menghasilkan tiga katekolamin yaitu hormon norepinephrine, epinephrine, dan sejumlah kecil dopamin.

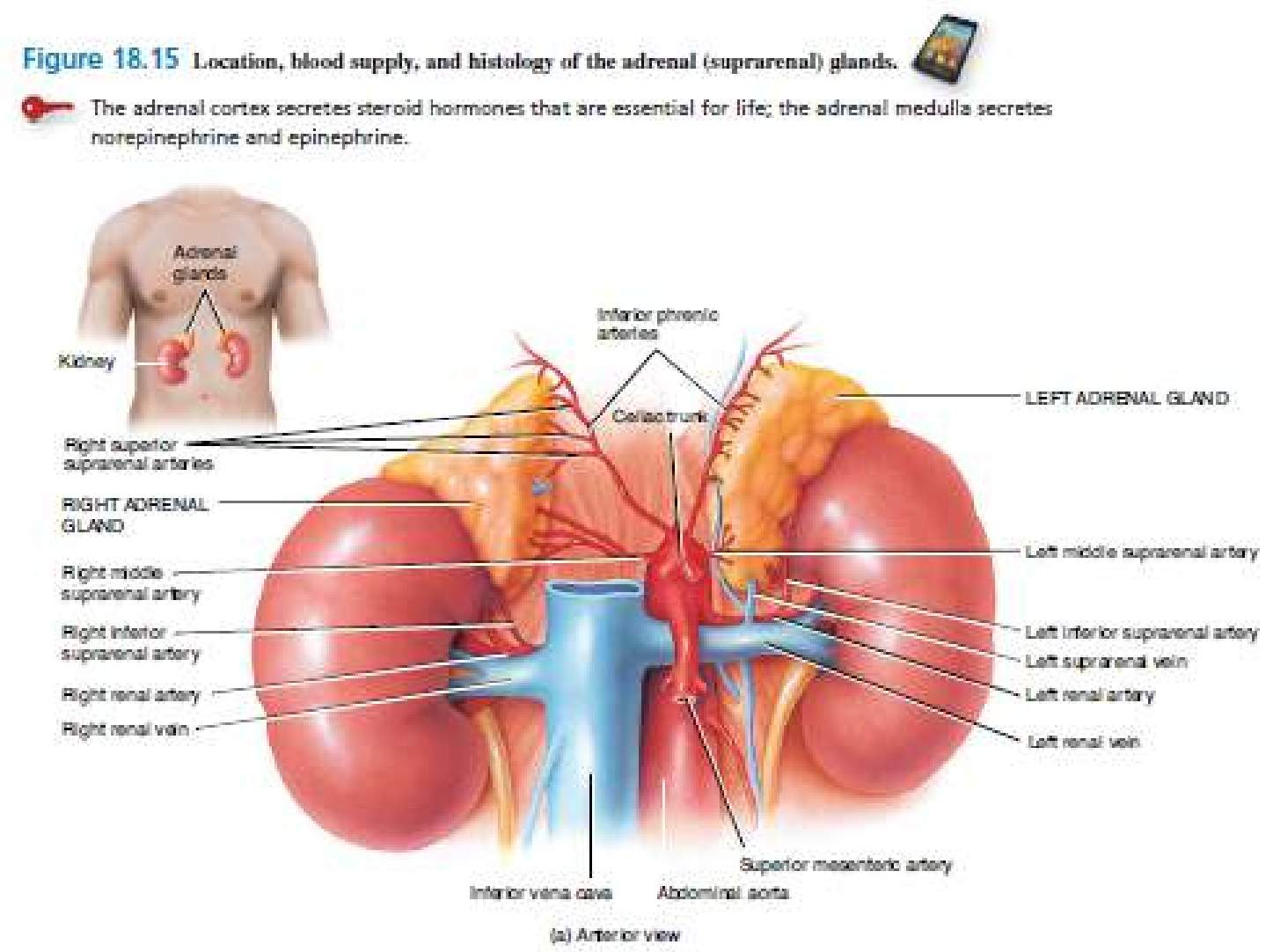

\section{Cortex adrenal}

Korteks adrenal dibagi menjadi tiga zona, masing-masing mengeluarkan hormon yang berbeda (Gambar 18.15d). Zona luar, hanya dalam untuk kapsul jaringan ikat, adalah zona glomerulosa. Sel, yang sangat erat yang dikemas dan tersusun dalam cluster berbentuk bola dan kolom yang melengkung, mensekresikan hormon yang disebut mineralocorticoids karena mereka mempengaruhi homeostasis mineral. Zona tengah, atau zona fasciculata, merupakan terluas dari tiga zona dan terdiri dari sel-sel tersusun dalam panjang, kolom lurus. Sel-sel dari zona tersebut fasciculata mensekresikan terutama glukokortikoid, terutama kortisol, dinamakan demikian karena mereka 
mempengaruhi homeostasis glukosa. Sel-sel dari zona dalam, zona reticularis, yang tersusun dalam percabangan kabel. Mereka mensintesis sejumlah kecil hormon androgen yang lemah, hormon steroid yang punya efek masculinizing.

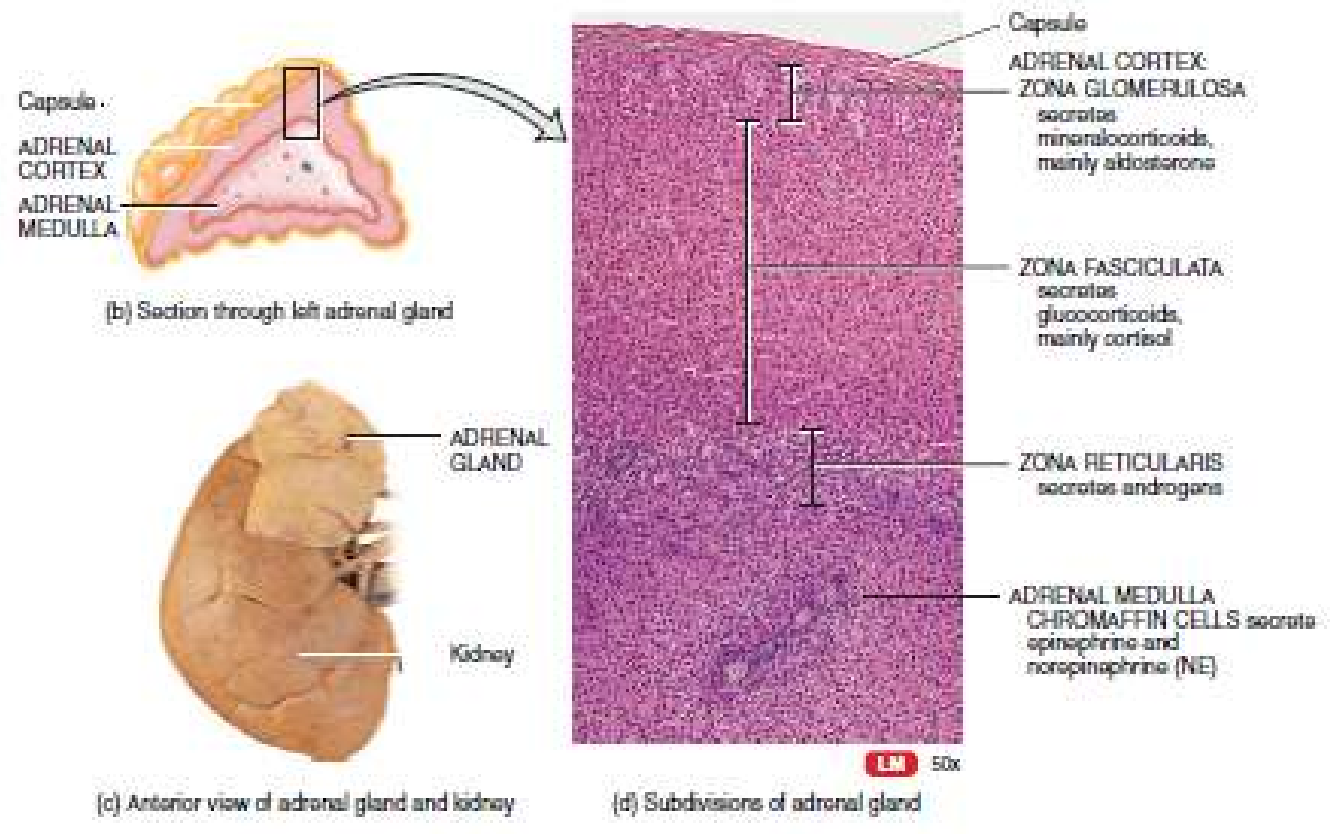

\section{Mineralokortikoid}

Aldosteron merupakan mineralokortikoid utama. Ini mengatur homeostasis dari dua ionyaitu mineral, ion natrium $\left(\mathrm{Na}^{+}\right)$Dan ion kalium $\left(\mathrm{K}^{+}\right)$Dan membantu mengatur tekanan darah dan volume darah. Aldosteron juga meningkatkan ekskresi $\mathrm{H}^{+}$dalam urin; penghapusan ini asam dari tubuh dapat membantu mencegah asidosis $(\mathrm{pH}$ darah di bawah 7.35) .

\section{Pengendalian aldosteron Sekresi}

1) Pathway Renin-angiotensin-aldosteron (RAA) mengontrol sekresi aldosteron,:

2) Stimulus yang memulai pathway renin-angiotensin-aldosteron termasuk dehidrasi, kekurangan $\mathrm{Na}+$, atau perdarahan.

3) Kondisi ini menyebabkan penurunan volume darah.

4) Penurunan volume darah menyebabkan penurunan tekanan darah.

5) Tekanan darah Menurunkan merangsang beberapa sel dari ginjal, yang disebut sel juxtaglomerular, untuk mensekresikan enzim renin.

6) Tingkat renin dalam darah meningkat.

7) Renin akan mengubah angiotensinogen, suatu protein plasma yang dihasilkan oleh hati, menjadi angiotensin I.

8) Kadar Angiotensin I dalam Darah meningkat dan beredar dalam tubuh.

9) Saat darah mengalir melalui kapiler, terutama paru-paru, enzim angiotensinconverting enzyme (ACE) mengubah angiotensin I menjadi hormon angiotensin II.

10) Tingkat angiotensin II dalam darah meningkat.

11) Angiotensin II merangsang korteks adrenal untuk mensekresikan aldosteron.

12) Darah berisi peningkatan kadar aldosteron dan diedarkan ke ginjal

13) Di ginjal, aldosteron meningkatkan reabsorpsi $\mathrm{Na}$, yang pada akhirnya menyebabkan reabsorpsi air melalui osmosis. Akibatnya, sedikit air hilang dalam 
urin. Aldosteron juga merangsang ginjal untuk meningkatkan sekresi $\mathrm{K}+\mathrm{dan} \mathrm{H}+$ ke dalam urin.

14) Dengan meningkatnya reabsorpsi air oleh ginjal, volume darah meningkat.

15) Seiring dengan peningkatan volume darah, tekanan darah meningkat dari normal.

16) Angiotensin II juga merangsang kontraksi otot polos di dinding arteriol. Vasokonstriksi yang dihasilkan dari arteriol meningkatkan tekanan darah dan dengan demikian membantu meningkatkan tekanan darah dari normal.

17) Selain angiotensin II, stimulator yang kedua sekresi aldosteron adalah peningkatan $\mathrm{K}+$ dalam darah (atau cairan interstitial). Penurunan tingkat $\mathrm{K}+$ darah memiliki dampak sebaliknya.

Figure 18.16 Regulation of aldosterone secretion by the renin-angiotensin-aldosterone (RAA) pathway.

- Aldosterone helps regulate blood volume, blood pressure, and levels of $\mathrm{Na}^{+}, \mathrm{K}^{+}$, and $\mathrm{H}^{+}$in the blood.

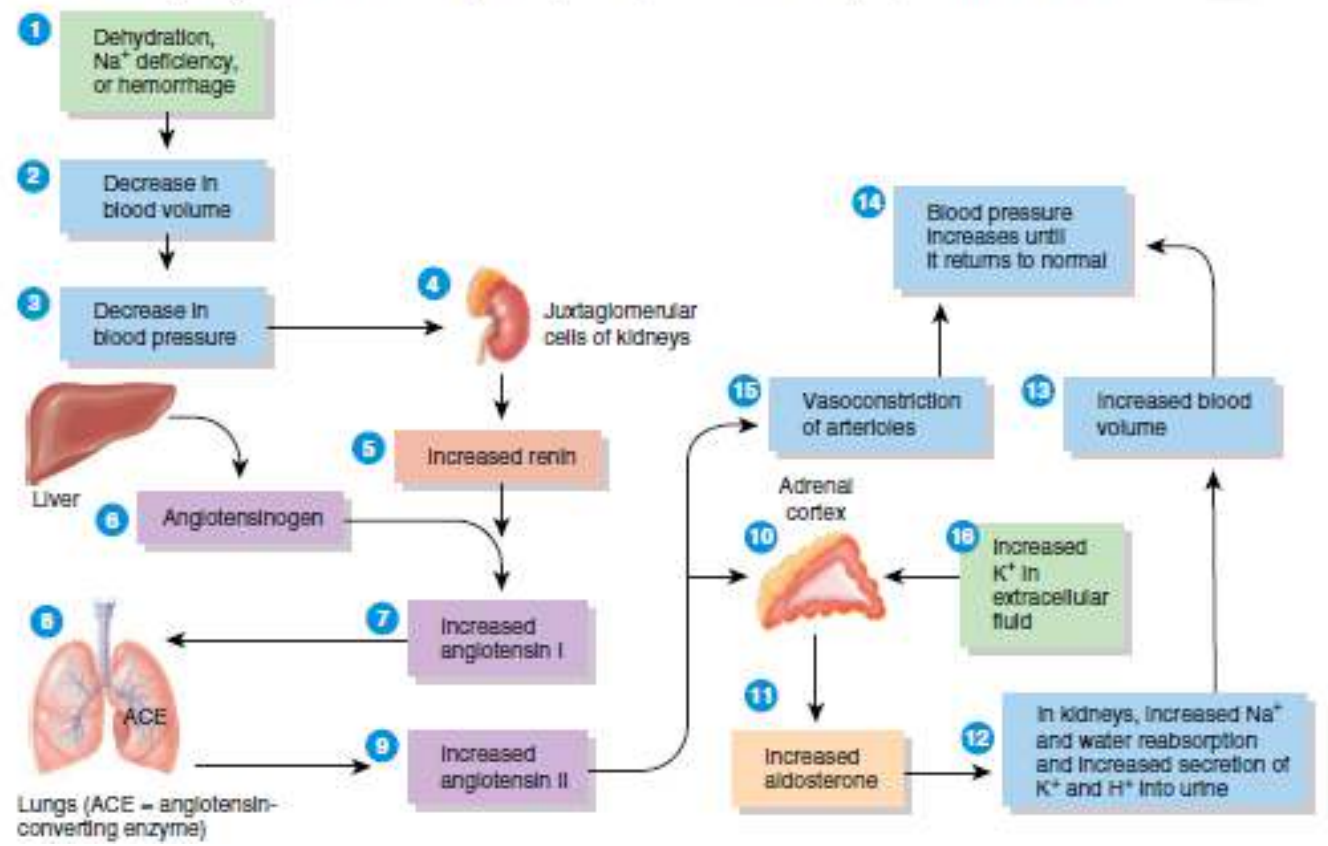

\section{Glukokortikoid}

glukokortikoid, dimana mengatur metabolisme tubuh dan daya tahan terhadap stres, termasuk kortisol (juga disebut hidrokortison), kortikosteron, dan kortison. Dari ketiga hormon ini disekresi oleh zona fasciculata, kortisol yang paling banyak, terhitung sekitar 95\% dari aktivitas glukokortikoid. Glukokortikoid memiliki efek sebagai berikut:

1) Pemecahan protein. Glukokortikoid meningkatkan kecepatan pemecahan protein, terutama dalam serat otot, dan dengan demikian meningkatkan pembebasan asam amino ke dalam aliran darah. Asam amino dapat digunakan oleh sel-sel tubuh untuk sintesis protein baru atau untuk memproduksi ATP.

2) pembentukan glukosa. Pada stimulasi oleh glukokortikoid, sel-sel hati dapat mengkonversi asam amino tertentu atau asam laktat menjadi glukosa, yang neuron dan sel-sel lain dapat digunakan untuk produksi ATP. Konversi yang terjadi dari zat selain glikogen atau monosakarida lain menjadi glukosa disebut glukoneogenesis.

3) Lipolisis. Glukokortikoid merangsang lipolisis, pemecahan trigliserida dan pelepasan asam lemak dari jaringan adiposa ke dalam darah. 
4) Daya tahan terhadap stress. Kerja glukokortikoid dengan berbagai cara untuk memberikan ketahanan terhadap stres. Glukosa tambahan yang disediakan oleh sel-sel hati menyediakan jaringan dengan sumber penyediaan ATP untuk mengatasi berbagai stres, termasuk olahraga, puasa, ketakutan, suhu ekstrim, ketinggian, perdarahan, infeksi, operasi, trauma, dan penyakit. Karena glukokortikoid membuat pembuluh darah lebih sensitif terhadap hormon lain yang menyebabkan vasokonstriksi, mereka meningkatkan tekanan darah. Efek ini akan menjadi keuntungan dalam kasus kehilangan darah yang parah, yang menyebabkan tekanan darah turun.

5) Efek anti-inflamasi. Glukokortikoid menghambat sel darah putih yang berpartisipasi dalam respon inflamasi. Sayangnya, glukokortikoid juga memperlambat perbaikan jaringan; akibatnya, mereka memperlambat penyembuhan luka. Meskipun dosis tinggi dapat menyebabkan gangguan mental yang berat, glukokortikoid sangat berguna dalam pengobatan gangguan inflamasi yang kronis seperti rheumatoid arthritis.

6) Depresi respon imun. Dosis tinggi glukokortikoid menekan respon imun. Karena suatu alasan ini, glukokortikoid diresepkan untuk penerima transplantasi organ untuk menghambat penolakan jaringan tubuh oleh sistem kekebalan tubuh.

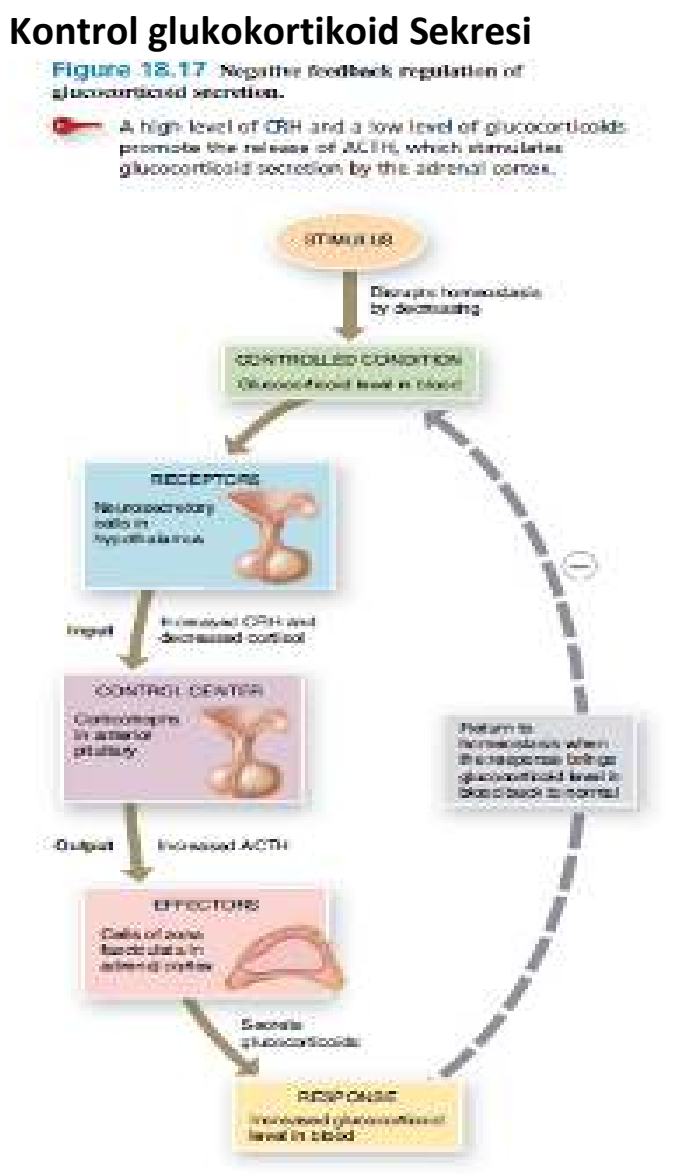

Kontrol sekresi glukokortikoid terjadi melalui sistem umpan balik negatif yang khas (Gambar 18.17). Tingkat glukokortikoid rendah dalam darah, terutama kortisol, merangsang sel neurosecretory di hipotalamus untuk mensekresikan corticotropin-releasing hormone (CRH). $\mathrm{CRH}$ (bersama-sama dengan rendahnya kortisol) mendorong pelepasan ACTH dari hipofisis anterior. ACTH mengalir dalam darah ke korteks adrenal, dimana merangsang sekresi glukokortikoid. (Untuk tingkat yang jauh yang lebih kecil, ACTH juga merangsang sekresi aldosteron.)

\section{Androgen}

Baik laki-laki dan perempuan, korteks adrenal mengeluarkan dalam jumlah kecil hormon androgen yang lemah. Androgen yang utama yang disekresi oleh kelenjar adrenal adalah dehydroepiandrosterone (DHEA). Setelah masa pubertas pada laki-laki, 
testosteron androgen juga dirilis dalam jumlah yang jauh lebih besar oleh testis. Dengan demikian, jumlah hormon androgen disekresikan oleh kelenjar adrenal pada laki-laki umumnya sangat rendah sehingga efeknya tidak signifikan. Pada wanita, bagaimanapun, hormon androgen adrenal memainkan peran penting. Mereka meningkatkan libido (sex drive) dan diubah menjadi estrogen (feminisasi steroid seks) oleh jaringan tubuh lainnya. Setelah menopause, ketika sekresi estrogen ovarium berhenti, semua estrogen wanita berasal dari konversi hormon androgen adrenal. hormon androgen adrenal juga merangsang pertumbuhan ketiak dan rambut kemaluan pada anak laki dan perempuan dan memberikan kontribusi pada percepatan pertumbuhan prapubertas. Meskipun kontrol sekresi androgen adrenal tidak sepenuhnya diketahui, hormon utama yang merangsang sekresi adalah ACTH.

\section{Adrenal Medulla}

Daerah dalam dari kelenjar adrenal, medula adrenal, adalah ganglion simpatik yang dimodifikasi dari sistem saraf otonom (ANS). Ini berkembang dari jaringan embrio yang sama seperti semua ganglia simpatik lainnya, tetapi sel-sel, yang tidak memiliki akson, cluster bentuk sekitar pembuluh darah besar. Daripada merilis neurotransmitter, sel-sel medula adrenal mensekresikan hormon. Sel-sel penghasil hormon, yang disebut sel chromaffin (lihat Gambar 18.15d), dipersarafi oleh neuron preganglionik simpatis dari ANS tersebut. Karena ANS memberikan kontrol langsung terhadap sel-sel chromaffin, pelepasan hormon dapat terjadi sangat cepat.

Dua hormon utama disintesis oleh medula adrenal adalah epinefrin dan norepinefrin (NE), juga disebut adrenalin dan noradrenalin, masing-masing. Sel-sel chromaffin dari medula adrenal mensekresikan jumlah hormon yang tidak merata sekitar $80 \%$ epinefrin dan norepinefrin $20 \%$. Hormon dari medula adrenal meningkatkan respon simpatik yang terjadi di bagian lain dari tubuh.

\section{Kontrol Sekresi epinefrin dan norepinefrin}

Dalam situasi stres dan selama latihan, impuls dari hipotalamus merangsang neuron preganglionik simpatis, yang pada akhirnya merangsang sel-sel chromaffin untuk mensekresikan epinefrin dan norepinefrin. Kedua hormon sangat meningkatkan respon fight-or-flight. Dengan cara meningkatkan denyut jantung dan kekuatan kontraksi, epinefrin dan norepinefrin meningkatkan Output dari jantung, sehingga meningkatkan tekanan darah. Mereka juga meningkatkan aliran darah ke jantung, liver, otot rangka, dan jaringan adiposa; melebarkan saluran udara ke paru-paru; dan meningkatkan kadar glukosa dan asam lemak. 


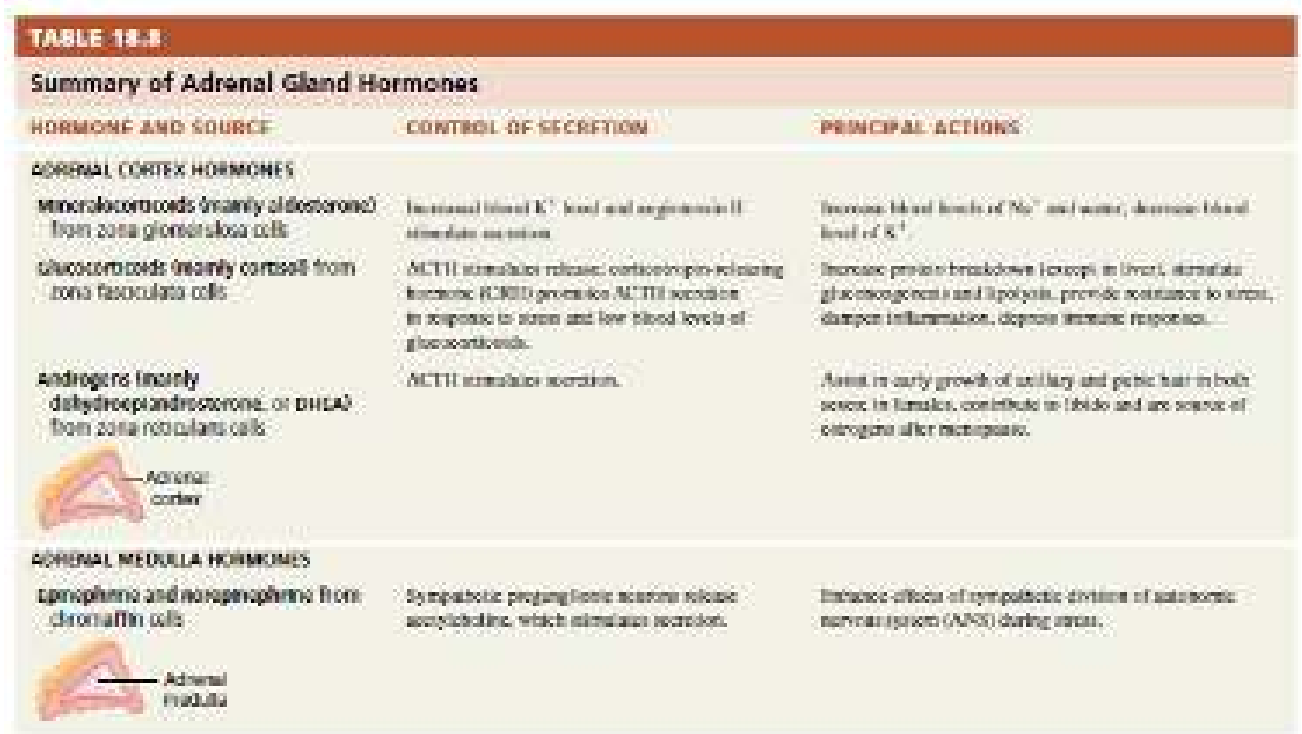

\section{Pankreas Islets}

Pankreas adalah kelenjar endokrin dan kelenjar eksokrin. bahasan di sini fungsi endokrin Suatu organ pipih yang Panjangnya sekitar 12,5-15 cm (5-6 in.), pankreas berlokasi di lekukan duodenum, bagian pertama dari usus kecil, dan terdiri dari kepala, tubuh, dan ekor (Gambar 18.18a), Sekitar 99\% dari sel-sel eksokrin pankreas disusun dalam kelompok yang disebut asinus. Asinus menghasilkan enzim pencernaan, dimana mengalir ke saluran pencernaan melalui jaringan duktus. Tersebar di antara asinus eksokrin yang 1-2 juta cluster kecil jaringan endokrin yang disebut pulau pankreas (I-lets) atau pulau Langerhans (Gambar 18.18b, c). Kapiler berlimpah bermanfaat baik untuk eksokrin dan endokrin bagian dari pankreas. 


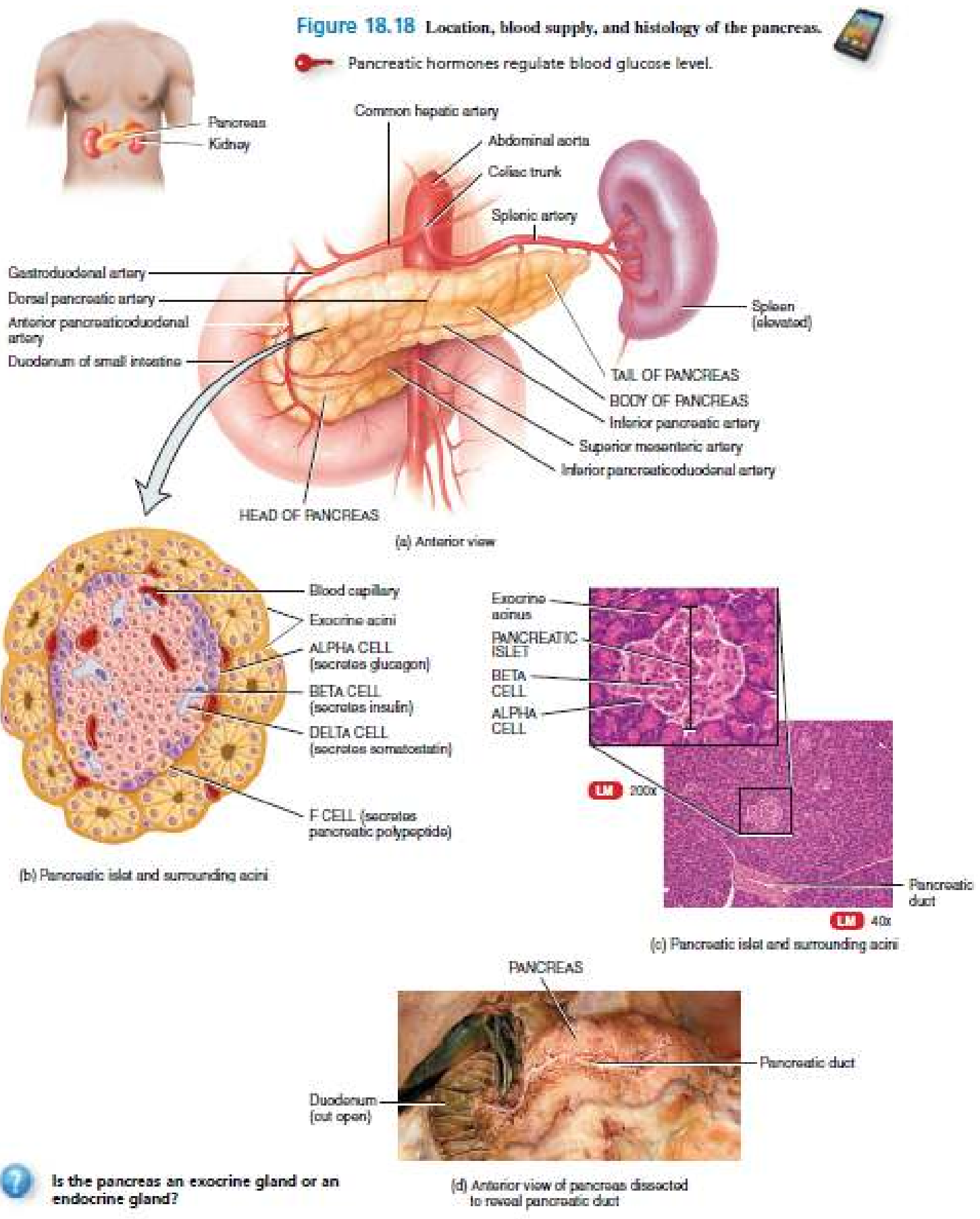

\section{Jenis sel di pankreas Islets}

Setiap pulau pankreas meliputi empat jenis sel yang mensekresi hormon:

1) Alpha atau Suatu sel mencakup sekitar $17 \%$ dari sel-sel islet pankreas dan mensekresikan glukagon.

2) Beta atau B sel mencakup sekitar $70 \%$ dari sel-sel islet pankreas dan mensekresikan insulin

3) Delta atau $D$ sel mencakup sekitar $7 \%$ dari sel islet pankreas dan mensekresikan somatostatin

4) sel F merupakan sisa sel islet pankreas dan mensekresikan polipeptida pankreas 
Interaksi dari empat hormon pankreas merupakan yang kompleks dan tidak sepenuhnya dipahami. Kita tahu bahwa glukagon meningkatkan kadar glukosa darah, dan insulin menurunkan. Tindakan somatostatin secara parakrin untuk menghambat baik rilis insulin dan glukagon dari sekitarsel beta dan alpha. Hal ini juga dapat bertindak sebagai hormon yang beredar untuk memperlambat penyerapan nutrisi dari saluran pencernaan. Selain itu, somatostatin menghambat sekresi growth hormone. Polipeptida pankreas menghambat sekresi somatostatin, kontraksi kandung empedu, dan sekresi enzim pencernaan oleh pankreas.

\section{Kontrol Sekresi Glukagon dan Insulin}

Figure 18.19 Negative feedback regulation of the secretion of glucagon (blue arrows) and insulin (orange arrows).

Low blood glucose stimulates relesse of glucagon; high blood glucose stimulates secretion of insulin.

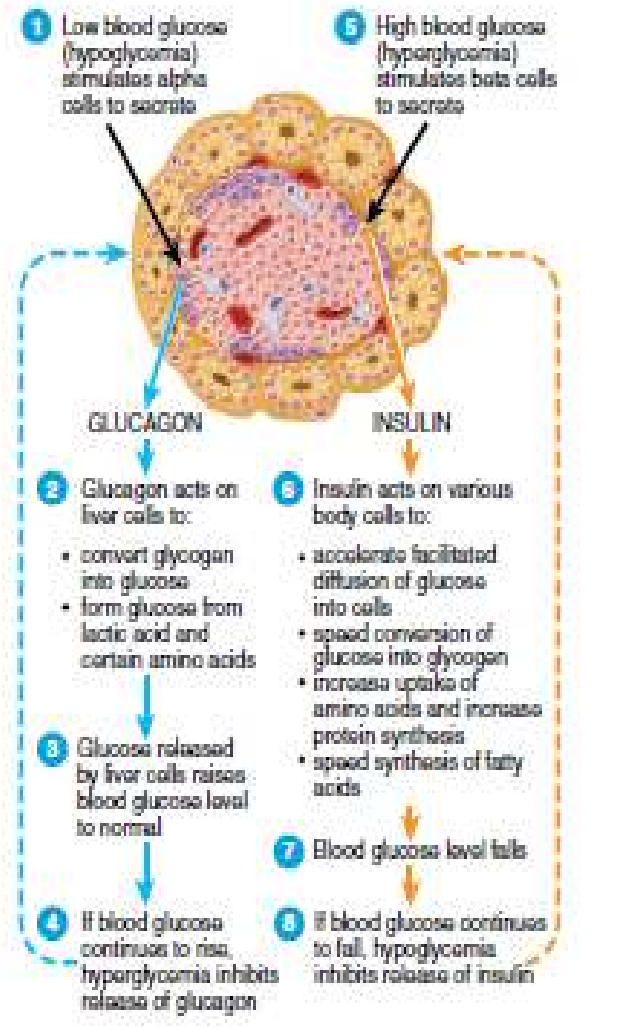

insulin oleh sel beta pankreas.
Aksi utama glukagon adalah untuk meningkatkan kadar glukosa darah ketika turun di bawah normal. Insulin, sebaliknya, membantu kadar gula darah saat terlalu tinggi. Tingkat glukosa dalam darah mengontrol sekresi glukagon dan insulin melalui umpan balik negatif (Gambar 18.19):

1) Kadar gula dalam darah rendah (hipoglikemia) merangsang sekresi glukagon dari sel alfa pulau pankreas.

2) Glukagon bekerja pada hepatosit (sel hati) untuk mempercepat konversi glikogen menjadi glukosa (glikogenolisis) dan untuk meningkatkan pembentukan glukosa dari asam laktat dan asam amino tertentu (glukoneogenesis).

3) Akibatnya, hepatosit glukosa rilis ke dalam darah lebih cepat, dan kadar gula darah naik.

4) Jika glukosa darah terus meningkat, kadar gula darah tinggi (hiperglikemia) menghambat pelepasan glukagon (umpan balik negatif).

5) Glukosa darah tinggi (hiperglikemia) menstimulasi sekresi

6) Tindakan insulin pada berbagai sel dalam tubuh untuk mempercepat Memfasilitasi difusi glukosa ke dalam sel; untuk mempercepat konversi glukosa menjadi glikogen (glikogenesis); untuk meningkatkan penyerapan asam amino oleh sel-sel dan meningkatkan sintesis protein; untuk sintesis kecepatan asam lemak (lipogenesis); untuk memperlambat konversi glikogen menjadi glukosa (glikogenolisis); dan untuk memperlambat pembentukan glukosa dari asam laktat dan asam amino (glukoneogenesis).

7) Akibatnya, kadar glukosa darah turun.

8) Jika Kadar gula dalam darah turun di bawah normal, glukosa darah rendah menghambat pelepasan insulin (umpan balik negatif) dan menstimulasi pelepasan glukagon. 
Walaupun Kadar gula dalam darah merupakan regulator yang paling penting dari insulin dan glukagon, beberapa hormon dan neurotransmiter juga mengatur pelepasan kedua hormon tersebut. Selain tanggapan terhadap Kadar gula dalam darah yang baru saja dijelaskan, glukagon menstimulasi pelepasan insulin secara langsung; insulin memiliki efek sebaliknya, menekan sekresi glukagon. Sebagai penurunan Kadar gula dalam darah dan insulin yang kurang dikeluarkan, sel-sel alfa pankreas yang dirilis dari efek penghambatan insulin sehingga mereka dapat mensekresikan lebih glukagon. Secara tidak langsung, human growth hormone ( $\mathrm{hGH}$ ) dan hormon adrenokortikotropik (ACTH) merangsang sekresi insulin karena mereka bertindak untuk meningkatkan glukosa darah.

Sekresi insulin juga dirangsang oleh:

1) Asetilkolin, neurotransmitter yang dibebaskan dari terminal akson dari serabut saraf vagus parasimpatis yang mempersarafi pulau pankreas

2) Asam amino arginin dan leusin, dimana akan hadir dalam darah pada tingkat yang lebih tinggi setelah protein yang mengandung makanan

3) Glucose-dependen insulinotropic peptida (GIP), * hormon yang dilepaskan oleh selsel enteroendokrin dari usus kecil

* GIP-yang sebelumnya disebut gaster inhibitor peptida-berganti nama karena pada konsentrasi fisiologis efek inhibitor pada fungsi lambung diabaikan. sebagai respons terhadap adanya glukosa dalam saluran pencernaan.

Dengan demikian, proses pencernaan dan penyerapan makanan yang mengandung karbohidrat dan protein memberikan stimulasi yang kuat untuk pelepasan insulin. Sekresi glukagon dirangsang oleh:

1) Peningkatan aktivitas dari simpatik dari ANS, seperti yang terjadi selama latihan

2) Kenaikan asam amino dalam darah jika Kadar gula dalam darah rendah, dimana dapat terjadi setelah makan yang berisikan protein utamanya. 


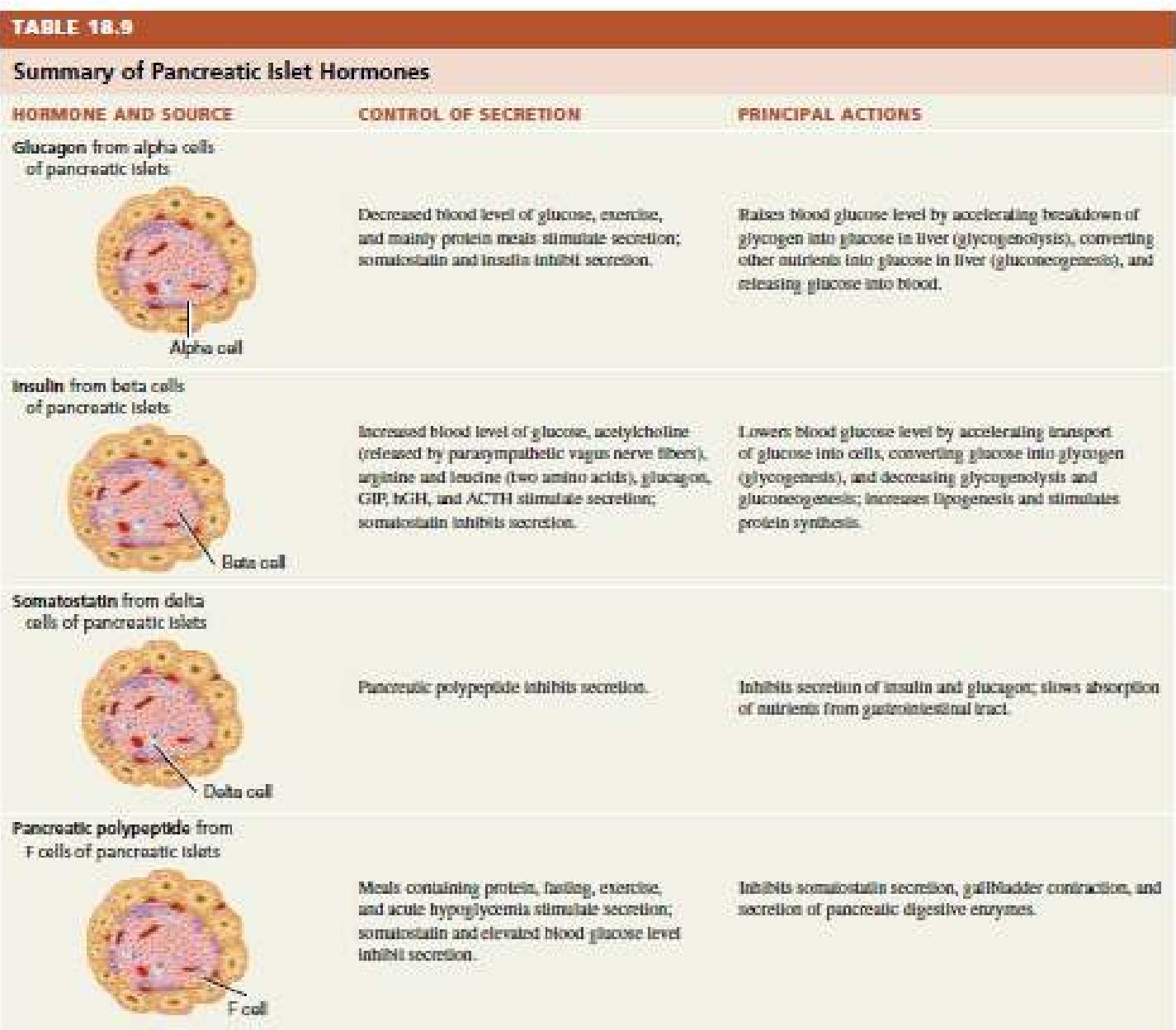

9. Ovarium dan Testis

\begin{tabular}{|c|c|}
\hline \multicolumn{2}{|c|}{ Summary of Hormones of the Ovaries and Testes } \\
\hline HORMONE & PRINCIPAL ACTIONS \\
\hline $\begin{array}{l}\text { OVARIAN HORM } \\
\text { Estrogens and } \\
\text { progesterone } \\
\text { Ovary }\end{array}$ & $\begin{array}{l}\text { Together with gonadotropic hormones of anterior } \\
\text { pituitary, regulale female reproductive cyele, } \\
\text { maintain pregnancy, pecpare mammary glands } \\
\text { for lactation, and promole developenent } \\
\text { and mainterance of female seoundary sex } \\
\text { characteristics. }\end{array}$ \\
\hline Relaxin (RLX) & $\begin{array}{l}\text { Increases flexihility of pubie symphysis during } \\
\text { pecenuncy; belps dilate uterine cervix during } \\
\text { labor and delivery. }\end{array}$ \\
\hline Inhibin & Inhibits secretion of FSH from anierior pituitury. \\
\hline \multicolumn{2}{|c|}{ TESTICULAR HORMONES } \\
\hline Testosterone & $\begin{array}{l}\text { Stimulates descent of testes before birth; } \\
\text { regulates sperm production; promoles } \\
\text { developinont and mainienanoc of male socondary } \\
\text { sex chancteristios. }\end{array}$ \\
\hline Testis: & \\
\hline Inhibin & Inkitits secretion of ISH from unterior pituitury. \\
\hline
\end{tabular}

Gonad adalah organ yang memproduksi gamet-sperma pada laki-laki dan oosit pada wanita. Selain fungsi reproduksi mereka, gonad mengeluarkan hormon. Ovarium, berpasangan tubuh berbentuk oval yang terletak di dalam rongga panggul perempuan, memproduksi beberapa hormon steroid, termasuk kedua estrogen (estradiol dan estron) dan progesteron. Hormon seks wanita ini, bersama dengan folliclestimulating hormone (FSH) dan luteinizing hormone (LH) dari hipofisis anterior, mengatur siklus menstruasi, menjaga kehamilan, dan mempersiapkan kelenjar susu untuk menyusui. Mereka juga 
meningkatkan pembesaran payudara dan pelebaran pinggul saat pubertas, dan membantu menjaga karakteristik seks sekunder perempuan.

Ovarium juga memproduksi inhibin, hormon protein yang menghambat sekresi FSH. Selama kehamilan, ovarium dan plasenta menghasilkan hormon peptida yang disebut relaksin (RLX), sehingga meningkatkan fleksibilitas simfisis pubis selama kehamilan dan membantu melebarkan serviks uterus selama persalinan dan melahirkan. Tindakan ini membantu meringankan bagian bayi dengan memperbesar jalan lahir.

Pada gonad laki-laki, testis, merupakan kelenjar berbentuk oval yang terletak di skrotum. Hormon utama yang dihasilkan dan disekresi oleh testis adalah testosteron, merupakan androgen atau hormon seks pria. Testosteron menstimulasi turunnya testis sebelum kelahiran, mengatur produksi sperma, dan menstimulasi perkembangan dan pemeliharaan karakteristik seks sekunder laki-laki, seperti pertumbuhan janggut dan pendalaman suara. Testis juga memproduksi inhibin, dimana menghambat sekresi FSH.

\section{Kelenjar Pineal Thymus}

Kelenjar pineal merupakan kelenjar endokrin yang kecil menempel pada atap dalam ventrikel sepertiga pada midline otak (lihat Gambar 18.1). Bagian dari epithalamus, posisi di antara kedua colliculi superior, memiliki massa 0.1-0.2 g, dan ditutupi oleh kapsul terbentuk dari pia mater. Kelenjar ini terdiri dari massa neuroglia dan sel sekretori disebut pinealocytes.

Kelenjar pineal mengeluarkan melatonin, hormon amina yang berasal dari serotonin. Melatonin muncul untuk berkontribusi pada pengaturan jam biologis tubuh, yang dikendalikan oleh inti suprachiasmatic hipotalamus. Karena semakin banyak melatonin dibebaskan selama gelap gulita daripada cahaya, hormon ini diduga untuk meningkatkan rasa kantuk. Sebagai respons terhadap input visual dari mata (retina), inti suprachiasmatic menstimulasi neuron postganglionik simpatik dari ganglion cervical superior, yang pada akhirnya merangsang pinealocytes kelenjar pineal untuk mensekresikan melatonin dengan pola berirama, dengan rendahnya tingkat melatonin disekresikan pada saat hari dan tingkat signifikan lebih tinggi disekresikan pada malam hari. Selama tidur, kadar plasma dari melatonin meningkat sepuluh kali lipat dan kemudian menurun ke tingkat yang rendah lagi sebelum kebangkitan. Dosis kecil melatonin yang diberikan secara oral dapat menginduksi tidur dan reset irama harian, yang mungkin akan bermanfaat bagi pekerja yang bergantian shift antara siang hari dan malam hari jam. Melatonin juga merupakan antioxidant yang potensial dapat memberikan perlindungan terhadap oksigen yang merusak radikal bebas.

Pada hewan yang berkembang biak selama musim tertentu, melatonin menghambat fungsi reproduksi, namun belum jelas apakah melatonin mempengaruhi fungsi reproduksi manusia. Tingkat melatonin berada lebih tinggi pada anak-anak dan menurun dengan usia menjadi dewasa, tetapi tidak ada bukti bahwa perubahan sekresi melatonin berhubungan dengan masa pubertas dan pematangan seksual. Namun demikian, karena melatonin menyebabkan atrofi gonad pada beberapa spesies hewan, kemungkinan efek samping pada reproduksi manusia harus dipelajari sebelum digunakan untuk mereset irama keseharian dapat dianjurkan. 
Timus ini terletak di belakang tulang dada antara paru-paru. Karena peran timus dalam kekebalan. Hormon yang dihasilkan oleh thymus-thymosin, thymus-humoral-factor (THF), thymus-factor (TF), dan thymopoietin -Mempromosikan pematangan sel $\mathrm{T}$ (sejenis sel darah putih yang menghancurkan mikroba dan zat asing) dan dapat memperlambat proses penuaan. 
Sistem kardiovaskuler merupakan organ sirkulsi darah yang terdiri dari jantung, komponen darah dan pembuluh darah yang berfungsi memberikan dan mengalirkan suplai oksigen dan nutrisi keseluruh jaringan tubuh yang di perlukan dalam proses metabolisme tubuh. Sistem kardivaskuler memerlukan banyak mekanisme yang bervariasi agar fungsi regulasinya dapat merespons aktivitas tubuh, salah satunya adalah meningkatkan aktivitas suplai darah agar aktivitas jaringan dapat terpenuhi. Pada keadaan berat, aliran darah tersebut, lebih banyak di arahkan pada organ-organ vital seperti jantung dan otak yang berfungsi memlihara dan mempertahankan sistem sirkulasi itu sendiri.

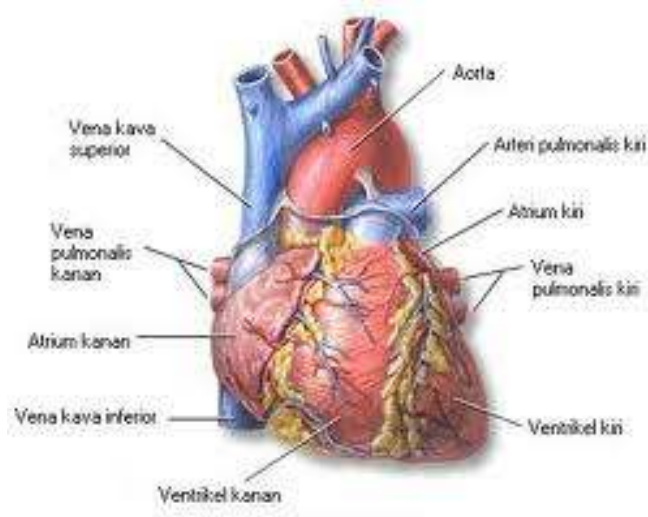

Gambar : Jantung pusat kardiovaskuler

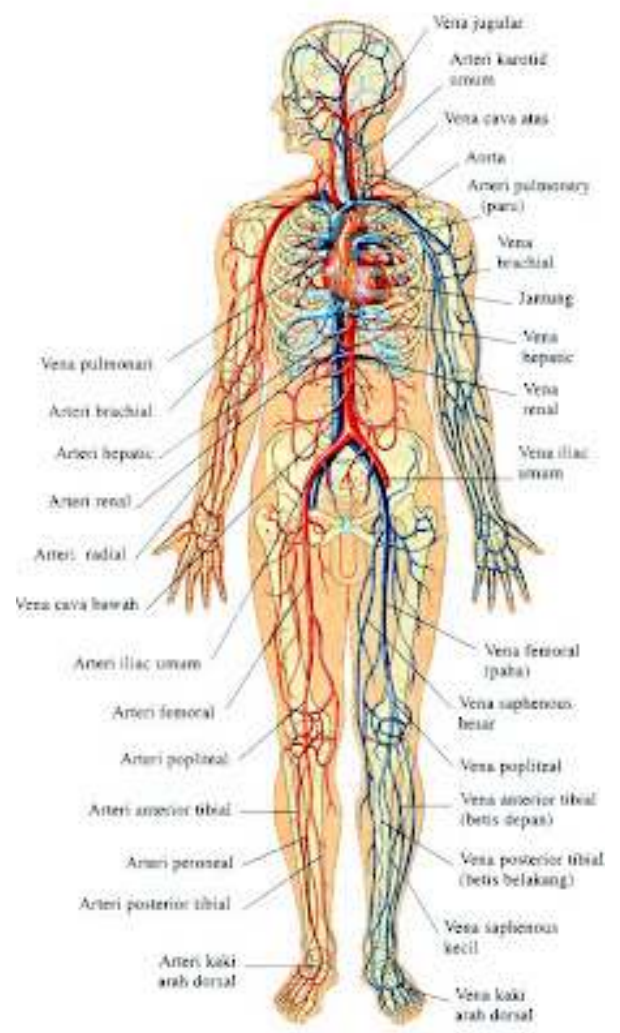

Gambar : Sistem kardiovaskuler

1. Perkembangan Sistem Kardiovaskuler

Sistem kardiovaskuler mulai berfungsi pada usia 3 minggu kehamilan. Dalam sistem kardiovaskuler terdapat pembuluh darah terbesar yang di sebut Angioblast. Angioblast ini timbul dari :

a. Mesoderm : splanknikus \& chorionic

b. Merengkim : yolk sac dan tali pusat

c. Dan dapat juga menimbulkan pembuluh darah dan darah

Dalam awal perkembangannya yaitu pada minggu ketiga, tabung jantung mulai berkembang di splanknikus yaitu antara bagian pericardial dan IEC dan atap katup uning telur sekunder(kardiogenik area). Tabung jantung pasangkan membujur endotel berlapis saluran. Tabung-tabung membentuk untuk menjadi jantung primordial. Jantung tubular bergabung dalam pembuluh darah di dalam embrio yang menghubungkan tangkai, karian 
dan yolk sac membentuk sistem kardivaskuler purba. Pada janin, proses peredaran darah melalui plasenta.

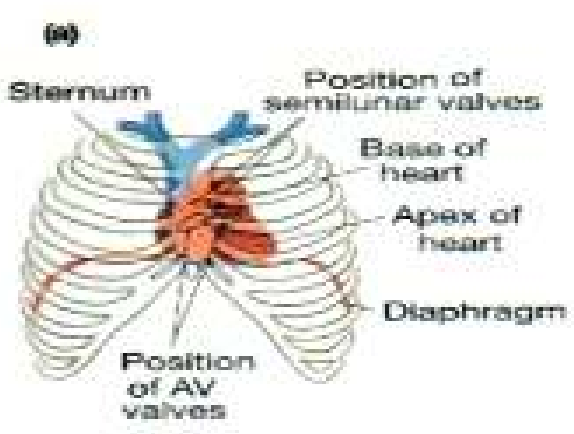

2. Anatomi dan Fisiologi Kardiovaskuler Jantung berbentuk seperti pir/kerucut seperti piramida terbalik dengan apeks (superior-posterior:C-II) berada di bawah dan basis ( anterior-inferior ICS $-\mathrm{V}$ ) berada di atas. Pada basis jantung terdapat aorta, batang nadi paru, pembuluh balik atas dan bawah dan pembuluh balik. Jantung sebagai pusat sistem kardiovaskuler terletak di sebelah rongga dada (cavum thoraks) sebelah kiri yang terlindung oleh costae tepatnya pada mediastinum. Untuk mengetahui denyutan jantung, kita dapat memeriksa dibawah papilla mamae 2 jari setelahnya. Berat pada orang dewasa sekitar 250-350 gram. Hubungan jantung dengan alat sekitarnya yaitu:

a) Dinding depan berhubungan dengan sternum dan kartilago kostalis setinggi kosta IIII.

b) Samping berhubungan dengan paru dan fasies mediastilais.

c) Atas setinggi torakal IV dan servikal II berhubungan dengan aorta pulmonalis, brongkus dekstra dan bronkus sinistra.

d) Belakang alat-alat mediastinum posterior, esophagus, aorta desendes, vena azigos, dan kolumna vetebrata torakalis.

e) Bagian bawah berhubungan dengan diafragma.

Jantung difiksasi pada tempatnya agar tidak mudah berpindah tempat. Penyokong jantung utama adalah paru yang menekan jantung dari samping, diafragma menyokong dari bawah, pembuluh darah yang keluar masuk dari jantung sehingga jantung tidak mudah berpindah. Factor yang mempengaruhi kedudukan jantung adalah:

a. Umur: Pada usia lanjut, alat-alat dalam rongga toraks termasuk jantung agak turun kebawah

b. Bentuk rongga dada: Perubahan bentuk tora yang menetap (TBC) menahun batas jantung menurun sehingga pada asma toraks melebar dan membulat

c. Letak diafragma: Jika terjadi penekanan diafragma keatas akan mendorong bagian bawah jantung ke atas

d. Perubahan posisi tubuh: proyeksi jantung normal di pengaruhi oleh posisi tubuh. 


\section{Otot jantung terdiri atas $\mathbf{3}$ lapisan yaitu:}

a) Luar/pericardium

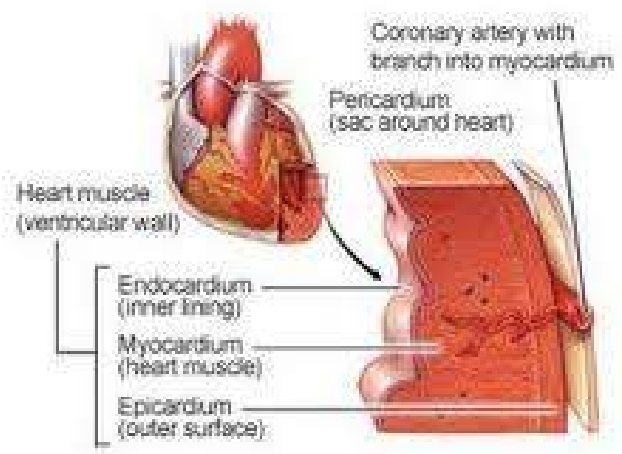

Berfungsi sebagai pelindung jantung atau merupakan kantong pembungkus jantung yang terletak di mediastinum minus dan di belakang korpus sterni dan rawan iga II- IV yang terdiri dari 2 lapisan fibrosa dan serosa yaitu lapisan parietal dan viseral. Diantara dua lapisan jantung ini terdapat lender sebagai pelican untuk menjaga agar gesekan pericardium tidak mengganggu jantung.

b) Tengah/ miokardium Lapisan otot jantung yang menerima darah dari arteri koronaria. Susunan miokardium yaitu:

i. Otot atria: Sangat tipis dan kurang teratur, disusun oleh dua lapisan. Lapisan dalam mencakup serabut-serabut berbentuk lingkaran dan lapisan luar mencakup kedua atria.

ii. Otot ventrikuler: membentuk bilik jantung dimulai dari cincin antrioventikuler sampai ke apeks jantung.

iii. Otot atrioventrikuler: Dinding pemisah antara serambi dan bilik( atrium dan ventrikel).

a) Dalam / Endokardium

Dinding dalam atrium yang diliputi oleh membrane yang mengilat yang terdiri dari jaringan endotel atau selaput lender endokardium kecuali aurikula dan bagian depan sinus vena kava.

\section{Bagian- bagian dari jantung:}

a. Basis kordis: bagian jantung sebelah atas yang berhubungan dengan pembuluh darah besar dan dibnetuk oleh atrium sinistra dan sebagian oleh atrium dekstra.

b. Apeks kordis : bagian bawah jantung berbentuk puncak kerucut tumpul.

\section{Permukaan jantung (fascies kordis) yaitu:}

a. Fascies sternokostalis: permukaan menghadap kedepan berbatasan dengan dinding depan toraks, dibentuk oleh atrium dekstra, ventrikel dekstra dan sedikit ventrikel sinistra.

b. Fascies dorsalis: permukaan jantung menghadap kebelakang berbentuk segiempat berbatas dengan mediastinum posterior, dibentuk oleh dinding atrium sinistra, sebgain atrium sinistra dan sebgain kecil dinding ventrikel sinistra.

c. Fascies diafragmatika: permukaan bagian bawah jantung yang bebatas dengan stentrum tindinium diafragma dibentuk oleh dinding ventrikel sinistra dan sebagian kecil ventrikel dekstra.

\section{Tepi jantung( margo kordis) yaitu:}

a. Margo dekstra: bagian jantung tepi kanan membentang mulai dari vena kava superior sampai ke apeks kordis 
b. Margo sinistra: bagian ujung jantung sebelah tepi membentang dari bawah muara vena pulmonalis sinistra inferior sampai ke apeks kordis.

\section{Alur permukaan jantung:}

a. Sulkus atrioventrikularis: Mengelilingi batas bawah basis kordis

b. Sulkus langitudinalis anterior: dari celah arteri pulmonalis dengan aurikula sinistra berjalan kebawah menuju apeks kordis.

c. Sulkus langitudinals posterior: dari sulkus koronaria sebelah kanan muara vena cava inferior menuju apeks kordis.

\section{Ruang-ruang jantung}

Jantung terdiri dari empat ruang yaitu:

1. Atrium dekstra: Terdiri dari rongga utama dan aurikula di luar, bagian dalamnya membentuk suatu rigi atau Krista terminalis.

a. Muara atrium kanan terdiri dari:

- Vena cava superior

- Vena cava inferior

- Sinus koronarius

- Osteum atrioventrikuler dekstra

b. Sisa fetal atrium kanan: fossa ovalis dan annulus ovalis

2. Ventrikel dekstra: berhubungan dengan atrium kanan melalui osteum atrioventrikel dekstrum dan dengan traktus pulmonalis melalui osteum pulmonalis. Dinding ventrikel kanan jauh lebih tebal dari atrium kanan terdiri dari:

- Valvula triskuspidal

- Valvula pulmonalis

3. Atrium sinistra: Terdiri dari rongga utama dan aurikula

4. Ventrikel sinistra: Berhubungan dengan atrium sinistra melalui osteum atrioventrikuler sinistra dan dengan aorta melalui osteum aorta terdiri dari:

- Valvula mitralis

- Valvula semilunaris aorta

\section{Peredaran darah jantung}

Vena kava superior dan vena kava inferior mengalirkan darah ke atrium dekstra yang datang dari seluruh tubuh. Arteri pulmonalis membawa darah dari ventrikel dekstra masuk ke paruparu(pulmo). Antara ventrikel sinistra dan arteri pulmonalis terdapat katup vlavula semilunaris arteri pulmonalis. Vena pulmonalis membawa darah dari paru-paru masuk ke atrium sinitra. Aorta (pembuluh darah terbesar) membawa darah dari ventrikel sinistra dan aorta terdapat sebuah katup valvulasemilunaris aorta.

Peredaran darah jantung terdiri dari 3 yaitu:

1. Arteri koronaria kanan: berasal dari sinus anterior aorta berjalan kedepan antara trunkus pulmonalis dan aurikula memberikan cabang-cabangke atrium dekstra dan ventrikel kanan.

2. Arteri koronaria kiri: lebih besar dari arteri koronaria dekstra 
3. Aliran vena jantung: sebagian darah dari dinding jantung mengalir ke atrium kanan melalui sinus koronarius yang terletak dibagian belakang sulkus atrioventrikularis merupakan lanjutan dari vena.

\section{Fungsi umum otot jantung yaitu:}

1. Sifat ritmisitas/otomatis: secara potensial berkontraksi tanpa adanya rangsangan dari luar.

2. Mengikuti hukum gagal atau tuntas: impuls dilepas mencapai ambang rangsang otot jantung maka seluruh jantung akan berkontraksi maksimal.

3. Tidak dapat berkontraksi tetanik.

4. Kekuatan kontraksi dipengaruhi panjang awal otot.

\section{Metabolisme Otot Jantung}

Seperti otot kerangka, otot jantung juga menggunakan energy kimia untuk berkontraksi. Energy terutama berasal dari metabolism asam lemak dalam jumlah yang lebih kecil dari metabolisme zat gizi terutama laktat dan glukosa. Proses metabolism jantung adalah aerobic yang membutuhkan oksigen.

\section{Pengaruh Ion Pada Jantung}

1. Pengaruh ion kalium : kelebihan ion kalium pada CES menyebabkan jantung dilatasi, lemah dan frekuensi lambat.

2. Pengaruh ion kalsium: kelebihan ion kalsium menyebabkan jantung berkontraksi spastis.

3. Pengaruh ion natrium: menekan fungsi jantung.

\section{Elektrofisiologi Sel Otot jantung}

Aktifitas listrik jantung merupakan akibat perubahan permeabilitas membrane sel. Seluruh proses aktifitas listrik jantung dinamakan potensial aksi yang disebabkan oleh rangsangan listrik, kimia, mekanika, dan termis. Lima fase aksi potensial yaitu:

1. Fase istirahat: Bagian dalam bermuatan negative(polarisasi) dan bagian luar bermuatan positif.

2. Fase depolarisasi(cepat): Disebabkan meningkatnya permeabilitas membrane terhadap natrium sehingga natrium mengalir dari luar ke dalam.

3. Fase polarisasi parsial: Setelah depolarisasi terdapat sedikit perubahan akibat masuknya kalsium ke dalam sel, sehingga muatan positih dalam sel menjadi berkurang.

4. Fase plato(keadaan stabil): Fase depolarisasi diikiuti keadaan stabil agak lama sesuai masa refraktor absolute miokard.

5. Fase repolarisasi(cepat): Kalsium dan natrium berangsur-angsur tidak mengalir dan permeabilitas terhadap kalium sangat meningkat.

\section{Sistem Konduksi Jantung}

Sistem konduksi jantung meliputi:

1. SA node: Tumpukan jaringan neuromuscular yang kecil berada di dalam dinding atrium kanan di ujung Krista terminalis.

2. AV node: Susunannya sama dengan SA node berada di dalam septum atrium dekat muara sinus koronari. 
3. Bundle atrioventrikuler: dari bundle $\mathrm{AV}$ berjalan ke arah depan pada tepi posterior dan tepi bawah pars membranasea septum interventrikulare.

4. Serabut penghubung terminal(purkinje): Anyaman yang berada pada endokardium

\section{Siklus Jantung} menyebar pada kedua ventrikel.

Empat pompa yang terpisah yaitu: dua pompa primer atrium dan dua pompa tenaga ventrikel. Periode akhir kontraksi jantung sampai kontraksi berikutnya disebut siklus jantung.

\section{Fungsi jantung sebagai pompa}

Lima fungsi jantung sebagai pompa yaitu:

1. Fungsi atrium sebagai pompa

2. Fungsi ventrikel sebagai pompa

3. Periode ejeksi

4. Diastole

5. Periode relaksasi isometric

Dua cara dasar pengaturan kerja pemompaan jantung

1. Autoregulasi intrinsic pemompaan akibat perubahan volume darah yang mengalir ke jantung.

2. Reflex mengawasi kecepatan dan kekuatan kontraksi jantung melalui saraf otonom

\section{Curah jantung}

Normal, jumlah darah yang dipompakan ventrikel kiri dan kanan sama besarnya. Jumlah darah yang dipompakan ventrikel selama satu menit disebut curah jantung (cardiac output). Faktor-faktor utama yang mempengaruhi otot jantung:

1. Beban awal

2. Kontraktilitas

3. Beban akhir

4. Frekuensi jantung

Periode pekerjaan jantung yaitu:

1. Periode systole

2. Periode diastole

3. Periode istirahat

\section{Bunyi Jantung}

Tahapan bunyi jantung:

1. Bunyi pertama: lup

2. Bunyi kedua : Dup

3. Bunyi ketiga: lemah dan rendah $1 / 3$ jalan diastolic individu muda

4. Bunyi keempat: kadang-kadang dapat didengar segera sebelum bunyi pertama

\section{Anatomi sistem pembuluh darah}

Pembuluh darah adalah prasarana jalan bagi aliran darah keseluruh tubuh. Aliran darah dalam tubuh terdiri dari:

1. Aliran darah koroner

2. Aliran darah portal

3. Aliran darah pulmonal 
BUKU AJAR ANATOMI FISIOLOGI KEPERAWATAN MEDIKAL BEDAH

4. Aliran darah sistemik 


\section{Arteri}

Arteri merupakan pembuluh darah yang keluar dari jantung yang membawa darah keseluruh tubuh dan alat tubuh. Pembuluh darah terbesar yang keluar dari ventrikel sinistra disebut aorta. Arteri terdiri dari 3 lapisan yaitu:

a. Tunika Intima Lapisan yang tipis, halus dan pipih yang dilapisi jaringan epitelium skuamosa

b. Tunika Media Lapisan yang terdiri atas oto polos dan sebagian jaringa fibrosa. Dalam arteri yang berukuran lebih besar, jumlah serat elastik ini lebih banyak, dan sebaliknya lebih sedikit dari arteri yang lebih kecil

c. Tunika Eksterna

Lapisan ini terdiri atas jaringan fibrosa yang melindungi pembuluh darah.

\section{Aorta}

Merupakan pembuluh darah arteri terbesar keluar dari jantung bagian ventrikel sinistra melalui aorta asendes membelok kebelakang melalui radiks pulmonalis sinistra, turun sepanjang kolumna vertebralis menembus diafragma, turun ke abdomen. Jalan arteri ini terdiri dari 3 bagian :
a. Aorta Asenden
b. Arkus Aorta
c. Aorta desendes

Aorta asendes mempunyai cabang:
a) Aorta torakalis
b) Aorta Abdominalis

\section{Arteri Kepala dan Leher}

Disuplai oleh arteri komunis dekstra dan sinistra. Pada masing-masing sisi menuju keatas leher dibawah otot sternomastoid dan pada ketinggian perbatasan atas kartilago tiroid membagi diri menjadi dua yaitu:

a. Arteri karotis eksterna

- A. tiroid superior

- A. faringea asendes

- A. lingualis

- A. fasialis

- A. aurikularis posterior

- A. maskilaris

b. Arteri karotis interna:

- A. oftalmika

- A. komunikan posterior

- A. coroidea

- A. serebri anterior

- A. serebri media

- A. nasalis 


\section{Arteri vertebralis}

Cabang bagian pertama subklavia berjalan naik melalui foramen prosesus transversi masuk ke cranium melalui foramen mahnum berjalan ke atas lalu kedepan medial medulla oblongata sampai di tepi bawah pons arteri ini bergabung dan membentuk $A$. basilaris cabang-cabang cranial A. vertebralis.

\section{Arteri basilaris}

Dibentuk oleh penggabungan dua A. vertebralis berjalan naik dalam alur. Pada permukaan anterior pons bercabang dua:

a. Arteri serebralis posterior

b. A. sirkumateriosus

Wajah menerima darah dari:

a. Arteri fasialis dan temporalis superficial

b. Arteri temporalis superficial

c. Arteri transversa fasialis

d. Arteri supraorbitalis dan supratoklearis

Arteri subklavia: terdiri dari dekstra yaitu cabang dari arteri anonima dan sinitra cabang dari arkus aorta. Terdiri dari:

- A. aksilaris

- A. brakhialis

- A.ulnaris

- A.radialis

- A. arkus Palmaris superfisialis

- A. arkus Palmaris profundus

- A. digitalis

\section{Aorta torakalis}

a. Rongga toraks terdiri dari:

- A.intercostalis

- A.perikardialis

- A.bronkialis

- A.esofagialis

- A. mediastinalis

b. Dinding toraks terdiri dari:

- Arteri prenikus superior

- Arteri subkostalis

Aorta abdominalis : merupakan bagian dari aorta desendens.

1. Arteri Rongga perut

Terdiri dari:

a. Arteri seliaka

b. A. splinika

c. A. mesenterika superior 

d. A. renalis
e. A. spermatika dan Ovarika
f. A. mesenterika Inferior
g. A. marginalis

2. Arteri dinding Abdomen

Arteri dinding abdomen muka dan belakan terdiri dari:
a. Prenikus inferior
b. Arteri subkostalis
c. Epigastrika superior
d. Arteri lumbalis

3. Rongga panggul

Terdiri dari:

a. Arteri iliaka interna

b. Arteri iliaka eksterna

\section{Vena}

Pembuluh darah vena adalah kebalikan dari arteri yang membawa darah dari alat-alat tubuh kembali ke jantung. Vena terbesar adalah vena pulmonalis. Pembuluh darah vena yang terdapat dalam tubuh yaitu:

1. Vena ke jantung

Meliputi : Vena cava superior, inferior dan pulmonalis

2. Vena yang bermuara pada vena cava superior : tepat dibelakang angulus mandibularis yang menyatu dengan vena aurikularis posterior turun melintasi $M$. sternokleidomastoideus tepat diatas clavikula menembus fasia servikalis profunda dan mencurahkan isinya ke V. subclavia. Cabang- cabangnya:
a. Vena aurikularis posterior
b. Vena retromadibularis
c. Vena jugularis eksterna posterior
d. Vena supraskapularis
e. Vena jugularis anterior superfisialis, aurikularis posterior dan oksipitalis.
4. Vena wajah: fasialis, profunda fasialis, transversa fasialis.
5. Vena pterigoideus : Vena maksilaris, fasialis, lingualis, oftalmika.
6. Vena tonsil dan palatum
7. Vena punggung
8. Vena yang bermuara pada vena cava interior
9. Anastomisis portal sistemik
10. Vena dinding pelvis
11. Vena anggota gerak atas dan,
12. Vena anggota gerak bawah

3. Vena kulit kepala : vena troklearis dan vena supraorbitalis, vena temporalis

\section{Kapiler}

Pembuluh darah yang paling kecil sehingga disebut dengan pembuluh rambut. Kapiler terdiri dari: 
1. Kapiler arteri

2. Kapiler vena Fungsi kapiler:

1. Penghubung arteri dan vena

2. Tempat pertukaran darah dan cairan jaringan

3. Mengambil hasil dari kelenjar

4. Menyerap zat makanan yang terdapat dalam usus

5. Menyaring darah dalam ginjal

\section{Sistem Pembuluhan Limfe}

Sistem pembuluh limfe merupakan suatu jalan tambahan tempat cairan dapat mengalir dari ruang interstitial ke dalam darah.pembuluh limfa dapat mengangkut protein dan zat partikel besar, keluar ruang jaringan yang tidak dikeluarkan dengan absorbs secara langsung kedalam kapiler darah. Sistem pembuluh limfe terdiri dari:

1. Duktus limfatikus dekstra: Duktus limfatikus jugularis dekstra, subclavia, dan bronkomediastinalis masing-masing mengalisrkan cairan limfa sisi kepala dan leher.

2. Duktus limfatikus sinistra: Mulai terlihat dalam abdomen sebagai kantong limfe yang memanjang.

3. Nodus limfatisi: Berbentuk lonjong seperti buah kacang dan terdapat di sepanjang pembuluh limfe.

4. Kapiler limfa: sedikit cairan yang kembali ke sirkulasi melalui pembuluh limfe.

\section{LIMPA}

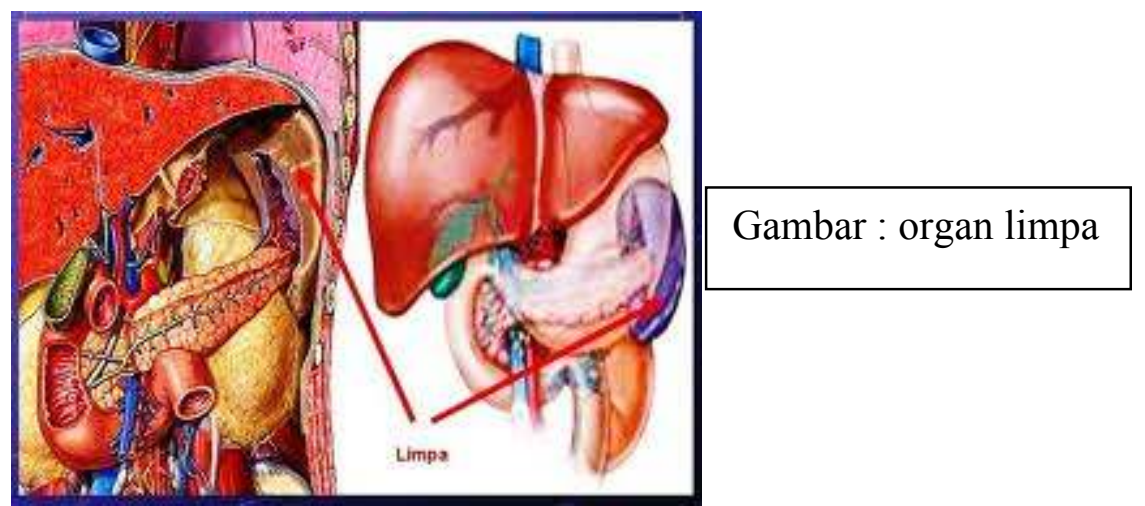

Terletak di sebelah kiri abdomen di daerah hipogastrium kiri bawah dan pada iga ke -9, 10 , dan 11 , berdekatan dengan fundus abdomen dan permukaannya menyentuh diafragma. Parenkim limpa terdiri dari:

1. Pulpa Putih

2. Pulpa Merah

\section{Fisiologi Vaskuler}

Sistem vaskuler memiliki peranan penting pada fisiologi kardiovaskuler karena berhubungan dengan mekanisme pemeliharaan lingkungan internal. Bagian- bagian yang berperan dalam sirkulasi:

1. Arteri mentranspor darah di bawah tekanan tinggi ke jaringan.

2. Arteriola, cabang kecil dari sistem arteri yang berfungsi sebagai kendali ketika darah yang dikeluarkan ke dalam kapiler. 
3. Kapiler, tempat pertukaran cairan, zat makanan dan elektrolit, hormone dan bahan lainnya antara darah dan cairan interstitial.

4. Venula yaitu mengumpulkan darah dari kapiler secara bertahap

5. Vena yaitu saluran penampung pengangkut darah dari jaringan kembali ke jantung.

\section{Aliran Darah}

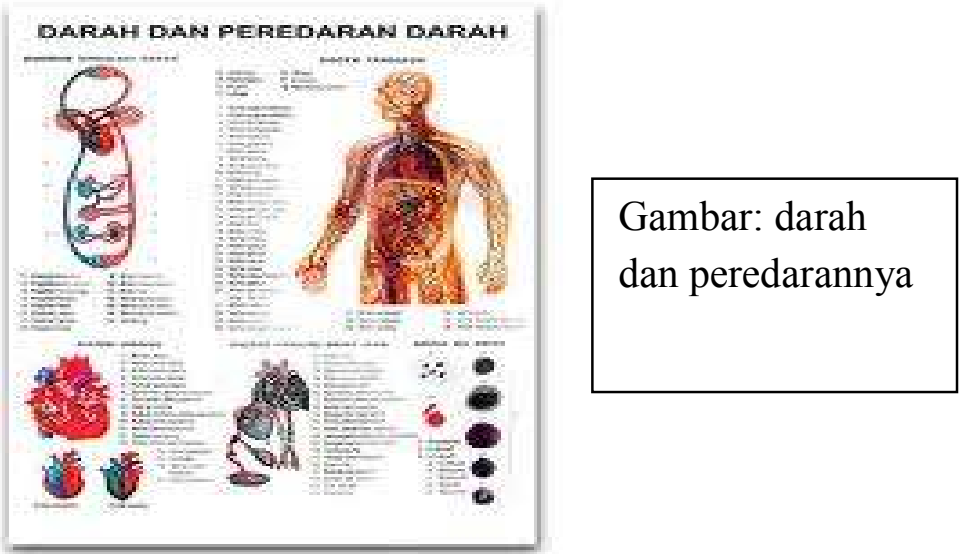

Kecepatan aliran darah ditentukan oleh perbedaan tekanan antara kedua ujung pembuluh darah. Pembuluh darah dan aliran arteri adalah:

1. Aliran darah dalam pembuluh darah

2. Tekanan darah arteri : Sistolik, diastolic, nadi, dan darah rata-rata.

3. Gelombang nadi.

4. Analisis gelombang nadi: dapat di nilai dari: frekuensi gelombang nadi, irama denyut nadi, amplitude dan ketajaman gelombang.

5. Factor yang mempengaruhi tekanan darah arteri.

Sedangkan Pembuluh dan Aliran Vena Yaitu:

1. Tekanan Vena: biasanya sangat rendah

2. Gelombang denyut vena: perubahan tekanan dan volume

3. Kurva denyut nadi: vena jugularis eksterna dengan cara non invasive

4. Kecepatan aliran darah vena

5. Factor yang mempengaruhi kecepatan aliran darah vena

6. Pengaruh gravitasi pada tekanan darah vena

\section{MIKROSIRKULASI}

Tempat pertukaran zat CIS dan CES (interstitial) adalah kapiler. Dan dipengaruhi oleh kecuali dinding kapiler, arteriole, venolus karena dapat mengatur jumlah dan kecepatan aliran darah. Ketiga rangkaian tersebut disebut dengan mikrosirkulasi.

\section{TEKANAN DARAH}

Selisih diastolic dan sistolik disebut pulse pressure. Misalnya tekanan sistolik $120 \mathrm{mmHg}$ dan diastolic $80 \mathrm{mmHg}$ maka tekanan nadi sama denga $40 \mathrm{mmHg}$. Tekanan darah tidak selalu sesuai karena salah satu factor yang mempengaruhinya adalah keadaan kesehatan dan aktivitas. Pusat pengawasan dan pengaturan perubahan tekanan darah yaitu:

1. Sistem saraf 
a. Presoreseptor dan kemoreseptor: serabut saraf aferen yang menuju pusat vasomotor berasal dari baroreseptor arteri dan kemoreseptor aortadan karotis dari korteks serebri.

b. Hipotalamus: Berperan dalam mengatur emosi dan tingkah laku yang berhubungan dengan pengaturan kardiovaskuler

c. Serebrum: Mempengaruhi tekanan dari karena penurunan respons tekanan, vasodilatasi, dan respons depressor meningkat.

d. Reseptor nyeri: bergantung pada intensitas dan lokasi stimulus

e. Reflex pulmonal: inflasi paru menimbulkan vasodilatasi sistemik dan penurunan tekanan darah arteri dan sebaliknya kolaps paru menimbulkan vasokonstriksi sistemik

2. Sistem humoral atau kimia: berlangsung local atau sistemik, misalnya rennin-angiotensin, vasopressin, epineprin, asetikolin, serotonin, adenosine, kalsium, magnesium, hydrogen dan kalium.

3. Sistem hemodinamik: lebih banyak dipengaruhi oleh volume darah, susunan kapiler, perubahan tekanan osmotic, dan hidrostatik bagian luar, dan dalam sistem vaskuler.

4. Sistem limfatik: komposisi sistem limfatik hampir sama dengan komposisi kimia plasma darah dan mengandung sejumlah besar limfosit yang mengalir sepanjang pembuluh limfe untuk masuk ke dalam aliran darah.

\section{Cairan limfatik}

Konsentrasi protein cairan limfe yang mengalir kebanyakan dari jaringan perifer mendekati nilai rata-rata atau pekat. Pembuluh limfatik berfungsi sebagai:

1. Mengembalikan cairan dan protein dari jaringan ke dalam sirkulasi darah

2. Mengankut limfosit dan kelenjar limfe ke sirkulasi darah

3. Membuat lemak yang sudah diemulsi dari usus ke sirkulasi darah

4. Menyaring dan menghancurkan mikroorganisme

5. Menghasilkan zat antibody 
Sistem muskuloskeletal merupakan penunjang bentuk tubuh dan mengurus pergerakan. Muskuloskeletal terdiri dari kata Muskulo yang berarti otot dan kata Skeletal yang berarti tulang. Muskulo atau muskular adalah jaringan otot-otot tubuh. Ilmu yang mempelajari tentang muskulo atau jaringan otot-otot tubuh adalah Myologi. Skeletal atau osteo adalah tulang kerangka tubuh. Ilmu yang mempelajari tentang muskulo atau jaringan otot-otot tubuh adalah Osteologi (Syaifudin, 2006).

\section{A. Komponen Sistem Musculoskeletal (Pearce, 2006).}

\section{A. Tulang}

Tulang adalah jaringan yang paling keras diantara jaringan ikat lainnya yang terdiri atas hampir $50 \%$ air dan bagian padat, selebihnya terdiri dari bahan mineral terutama calsium kurang lebih $67 \%$ dan bahan seluler $33 \%$.

Fungsi dari tulang adalah sebagai berikut :

1. Mendukung jaringan tubuh dan memberikan bentuk tubuh.

2. Melindungi organ tubuh (jantung, otak, paru-paru, dan jaringan lunak).

3. Memberikan pergerakan (otot berhubungan dengan kontraksi dan pergerakan).

4. Membentuk sel-sel darah merah di dalam sumsum tulang (hematopoesis).

5. Menyimpan garam-garam mineral (kalsium, fosfor, magnesium dan fluor).

\section{Struktur tulang}

Tulang diselimuti di bagian luar oleh membran fibrus padat disebut periosteum. Periosteum memberikan nutrisi pada tulang dan memungkinkan tumbuh, selain sebagai tempat perlekatan tendon dan ligament. Periosteum mengandung saraf, pembuluh darah, dan limfatik. Lapisan yang terdekat mengandung osteoblast . Dibagian dalamnya terdapat endosteum yaitu membran vascular tipis yang menutupi rongga sumsum tulang panjang dan rongga dalam tulang kanselus. Osteoklast terletak dekat endosteum dan dalam lacuna howship (cekungan pada permukan tulang).

Sumsum tulang merupakan jaringan vascular dalam rongga sumsum (batang) tulang panjang dan tulang pipih. Sumsum tulang merah terutama terletak di sternum, ilium, vetebra dan rusuk pada orang dewasa, bertanggungjawab dalam produksi sel darah merah dan putih. Pada orang dewasa tulang panjang terisi oleh sumsum lemak kuning. Jaringan tulang mempunyai vaskularisasi yang baik. Tulang kanselus menerima asupan darah melalui pembuluh metafis dan epifis. Pembuluh periosteum mengangkut darah ke tulang kompak melalui kanal volkman. Selain itu terdapat arteri nutrient yang menembus periosteum dan memasuki rongga meduler melalui foramina (lubanglubang kecil). Arteri nutrient memasok darah ke sumsum tulang, System vena ada yang keluar sendiri dan ada yang mengikuti arteri.

Tulang tersusun dari 3 jenis sel yaitu :

a. Osteoblas

Osteoblas berfungsi dalam pembentukan tulang dengan mensekresikan matrik tulang. Matrik tulang tersusun atas $98 \%$ kolagen dan 2\% substansi dasar (glukosaminoglikan/ asam polisakarida dan proteoglikan). Matrik tulang 
merupakan kerangka dimana garam garam mineral ditimbun terutama calsium, fluor, magnesium dan phosphor.

b. Osteosit

Osteosit adalah sel-sel tulang dewasa yang bertindak sebagai pemeliharaan fungsi tulang dan terletak pada osteon (unit matrik tulang). Osteon yaitu unit fungsional mikroskopik tulang dewasa yang di tengahnya terdapat kapiler dan disekeliling kapiler tedapat matrik tulang yang disebut lamella. Di dalam lamella terdapat osteosit, yang memperoleh nutrisi lewat prosesus yang berlanjut kedalam kanalikuli yang halus (kanal yang menghubungkan dengan pembuluh darah yang terletak kurang lebih 0,1 mm).

c. Osteoklas

Osteoklas adalah sel-sel besar berinti banyak memungkinkan mineral dan matriks tulang dapat diabsorpsi, penghancuran dan remodeling tulang. Tidak seperti osteoblas dan osteosit, osteoklas mengikis tulang.

Tulang merupakan jaringan yang dinamis dalam keadaan peralihan tulang (resorpsi dan pembentukan tulang). Kalium dalam tubuh orang dewasa diganti $18 \%$ pertahun.
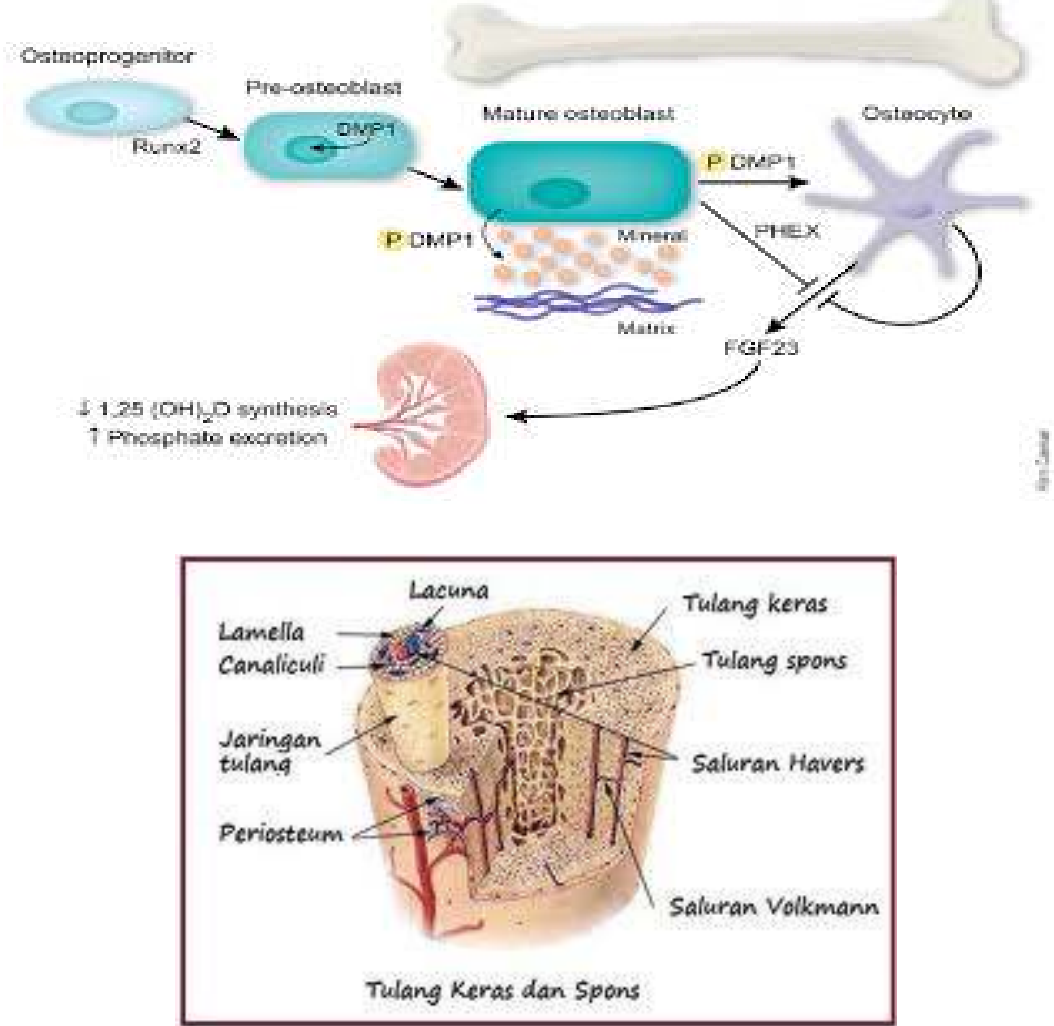

Gambar 1.1 struktur tulang

Faktor yang berpengaruh terhadap keseimbangan pembentukan dan reabsorpsi tulang adalah :

1. Vitamin D

Berfungsi meningkatkan jumlah kalsium dalam darah dengan meningkatkan penyerapan kalsium dari saluran pencernaan. Kekurangan vitamin $D$ dapat menyebabkan deficit mineralisas, deformitas dan patah tulang.

2. Horman parathyroid dan kalsitonin 
Merupakan hormone utama pengatur homeostasis kalsium. Hormon parathyroid mengatur konsentrasi kalsium dalam darah, sebagian dengan cara merangsang perpindahankalsium dari tulang. Sebagian respon kadar kalsiumdarah yang rendah, peningkatan hormone parathyroid akan mempercepat mobilisasi kalsium, demineralisasi tulang, dan pembentukan kista tulang. Kalsitonin dari kelenjar tiroid meningkatkan penimbunan kalsium dalam tulang.

3. Peredaran darah

Pasokan darah juga mempengaruhi pembentukan tulang. Dengan menurunnya pasokan darah / hyperemia (kongesti) akan tejadi penurunan osteogenesis dan tulang mengalami osteoporosis (berkurang kepadatannya). Nekrosis tulang akan terjadi bila tulang kehilangan aliran darah.

Pada keadaaan normal tulang mengalami pembentukan dan absorpsi pada suatu tingkat yang konstan, kecuali pada masa pertumbuhan kanak-kanak diman lebih banyak terjadi pembentukan dari pada absorpsi tulang.

Proses ini penting untuk fungsi normal tulang. Keadaan ini membuat tulang dapat berespon terhadap tekanan yang meningkat dan untuk mencegah terjadi patah tulang. Perubahan tesebut membantu mempertahankan kekuatan tulang pada proses penuaan. Matrik organic yang sudah tua berdegenerasi, sehingga membuat tulang relative menjadi lemah dan rapuh. Pembentukan tulang baru memerlukan matrik organic baru, sehingga memberi tambahan kekuatan tulang. (Price,S.A,1995 : 1179)

Berdasarkan bentuknya tulang dapat diklasifikasikan sebagai berikut :

1. Tulang Panjang / Tulang Pipa

Tulang ini sering terdapat dalam anggota gerak. Fungsinya sebagai alat ungkit dari tubuh dan memungkinkan untuk bergerak. Batang atau diafisis tersusun atas tulang kortikal dan ujung tulang panjang yang dinamakan epifis tersusun terutama oleh tulang kanselus. Plat epifis memisahkan epifiis dan diafisis dan merupakan pusat pertumbuhan longitudinalpada anak-anak. Yang pada orang dewasa akan mengalami kalsifikasi. Misalnya pada tulang humerus dan femur.

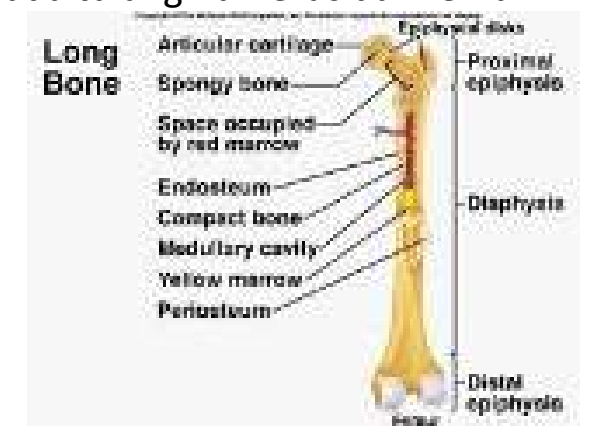

Gambar 1.2 Struktur tulang panjang

2. Tulang Pendek

Tulang ini sering didapat pada tulang-tulang karpalia di tangan dan tarsalia di kaki. Fungsinya pendukung seperti tampak pada pergelangan tangan. Bentuknya tidak teratur dan inti dari konselus (spongi) dengan suatu lapisan luar dari tulang yang padat.

3. Tulang Pipih 
Tulang ini sering terdapat di tengkorak, panggul / koxa, sternum, dan iga-iga, serta scapula (tulang belikat). Fungsinya sebagai pelindung organ vital dan menyediakan permukaan luas untuk kaitan otot-otot, merupakan tempat penting untuk hematopoesis. Tulang pipih tersusun dari tulang kanselus diantara 2 tulang kortikal.

4. Tulang Tak Beraturan

Berbentuk unik sesuai dengan fungsinya. Struktur tulang tidak teratur, terdiri dari tulang kanselous di antara tulang kortikal. Contoh : tulang vertebra, dan tulang wajah.

5. Tulang Sesamoid

Merupakan tulang kecil disekitar tulang yang berdekatan dengan persendian dan didukung oleh tendon dan jaringan fasial. Contoh : tulang patella (Kap lutut). Bentuk dan kontruksi tulang ditentukan fungsi dan gaya yang bekerja padanya. 


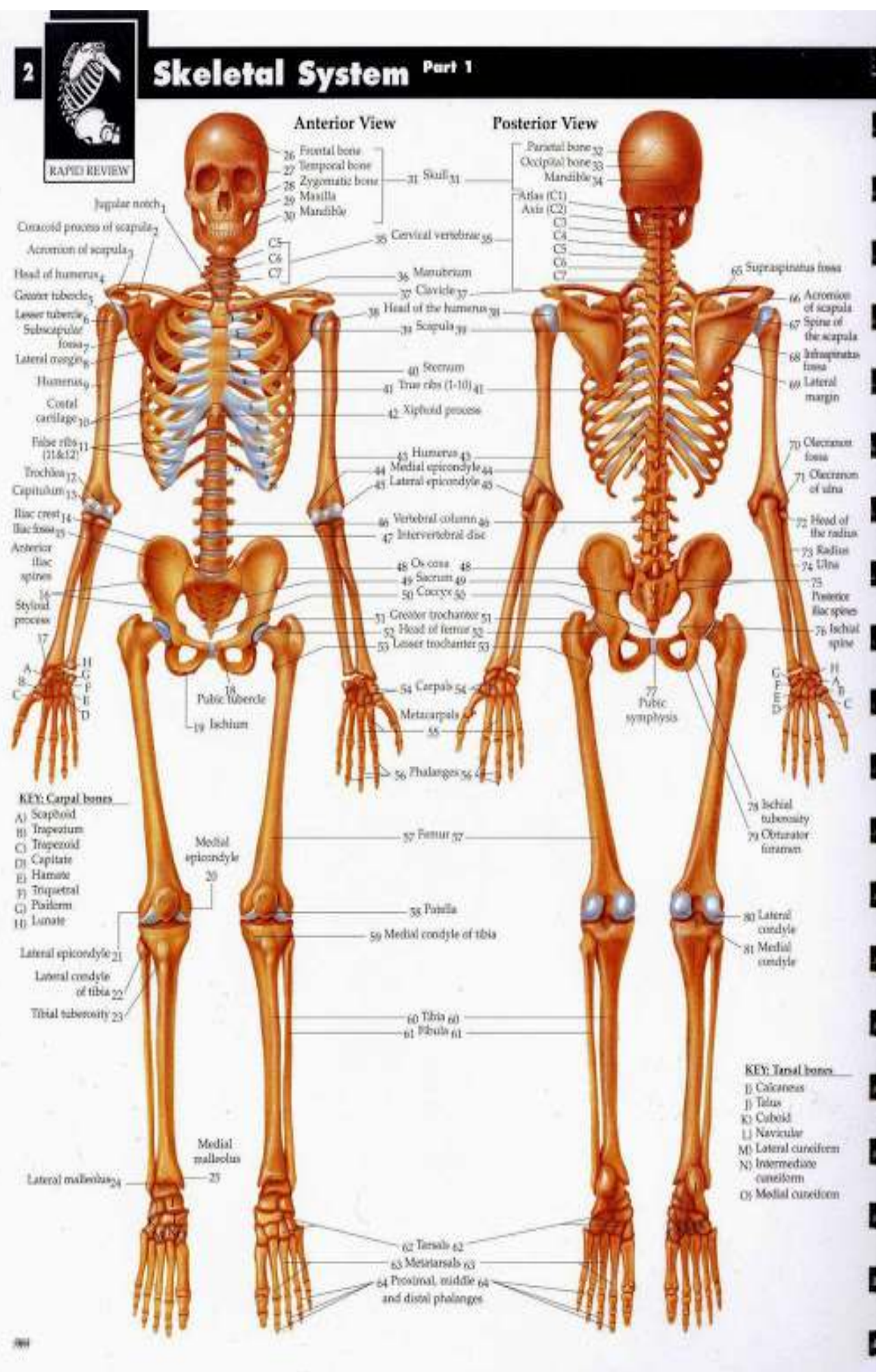

\section{B. Kerangka}

Sebagian besar tersusun atas tulang. Kerangka tulang merupakan kerangka yang kuat untuk menyangga struktur tubuh. Kerangka dibagi menjadi :

1) Kerangka aksial

Kerangka aksial terdiri dari 80 tulang, terkelompok pada 3 daerah yaitu : 
- Kranium dan Tulang Muka ( TENGKORAK )

Kranium terdiri atas 8 tulang yaitu tulang-tulang parietal (2), temporal (2),frontal, oksipital, stenoid, dan etmoid. Tulang muka terdiri atas 14 tulang yaitu tulang maksila (2), zigomatikus (2), nasal (2), lakrimal (2), palatinum (2),concha inferior (2), mandibula dan vomer.

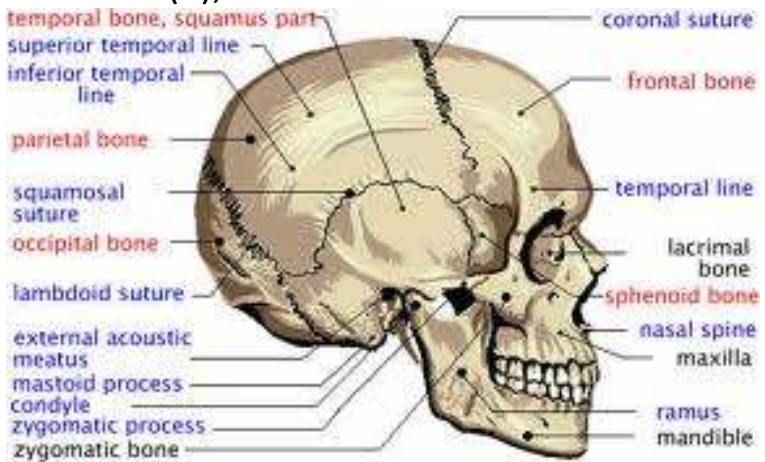

- Kolumna Vertebralis

Kolumna vertebralis terdiri atas 26 tulang berbentuk tidak teratur, terbentang antara tengkorak dan pelvis. Juga merupakan tempat melekatnya iga dan otot punggung. Kolumna vertebralis dibagi dalam 7 vertebra sevikalis, 12 vertebra torakalis, 5 vertebra lumbalis, 5 vertebra sacrum dan 4 vertebra koksigius.

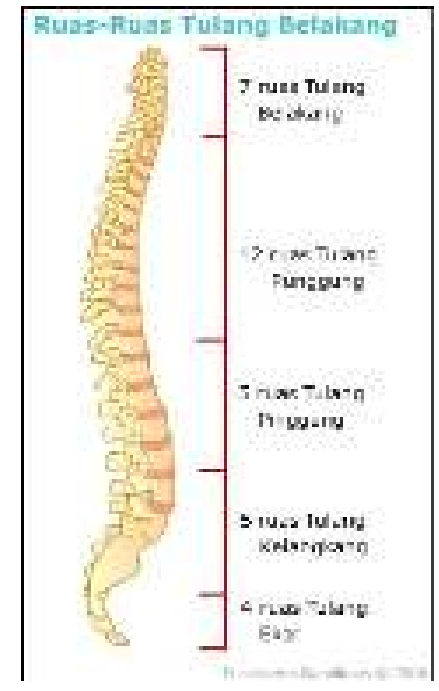

- Thoraks tulang

Thorak tulang terdiri tulang dan tulang rawan. Thoraks berupa sebuah rongga berbentuk kerucut terdiri dari 12 vertebra torakalis dan 12 pasang iga yang melingkar dari tulang belakang sampai ke sternum. Pada sternum terdapat beberapa titik penting yaitu supra sternal notch dan angulus sterni yaitu tempat bertemunya manubrium dan korpus sterni. Bagian-bagian tersebut merupakan penunjang kepala, leher, dan badan serta melindungi otak, medulla spinalis dan organ dalam thoraks. 


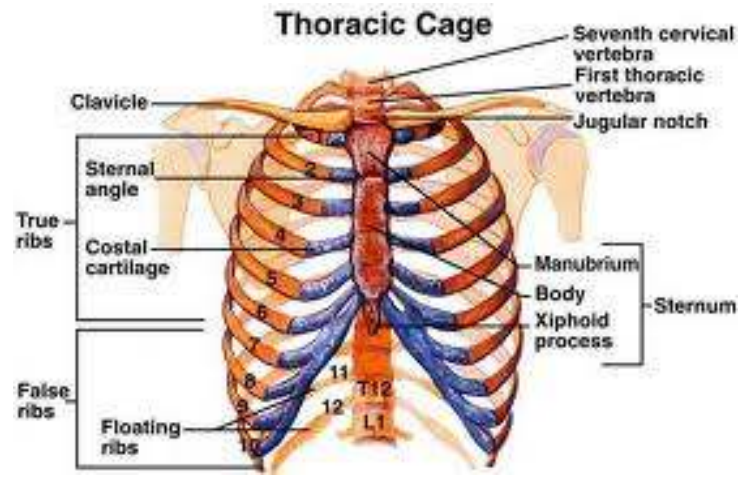

2) Kerangka Apendikular

Kerangka apindikuler terdiri atas :

- Bagian bahu (Singulum membri superioris)

Singulum membri superior terdiri atas klavikula dan scapula. Klavikula mempunyai ujung medial yang menempel pada menubrium dekat suprasternal notch dan ujung lateral yang menempel pada akronion.

- Bagian panggul (Singulum membri inferior)

Terdiri dari ileum, iskium, pubis yang bersatu disebut tulang koksae. Tulang koksae bersama sacrum dan koksigeus membentuk pelvis tulang. Ekstremitas bawah terdiri dari femur, patella, tibia, fibula, tarsus, metatarsus.

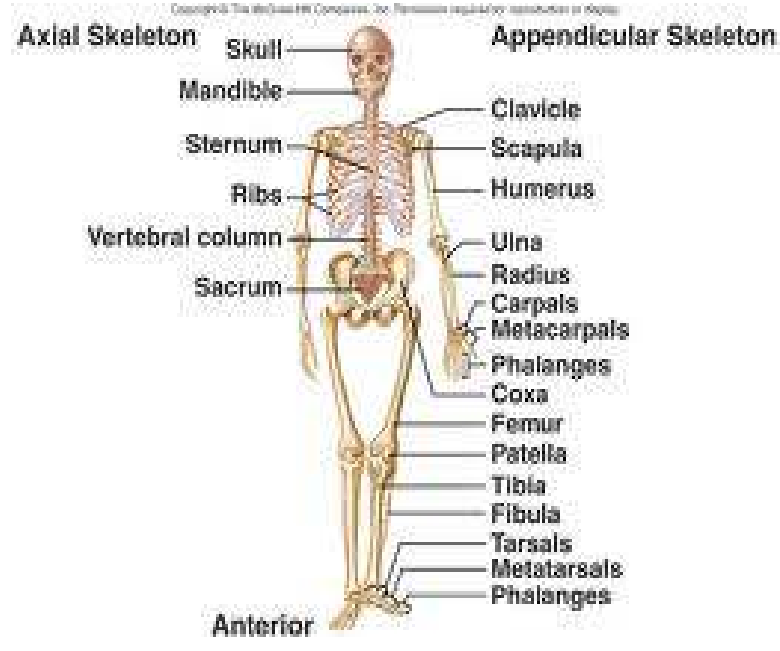

\section{B. Cartilago (tulang rawan)}

Tulang rawan terdiri dari serat-serat yang dilekatkan pada gelatin kuat, tetapi fleksible dan tidak bervasculer. Nutrisi melaui proses difusi gel perekat sampai ke kartilago yang berada pada perichondium (serabut yang membentuk kartilago melalui cairan sinovial), jumlah serabut collagen yang ada di cartilage menentukan bentuk fibrous, hyaline, elastisitas, fibrous (fibrocartilago) memili paling banyak serabut dan memiliki kekuatan meregang. Fibrus cartilage menyusun discus intervertebralis articular (hyaline) cartilage halus, putih, mengkilap, dan kenyal membungkus permukaan persendian dari tulang dan berfungsi sebagai bantalan. Cartilage yang elastis memiliki sedikit serat dan terdapat pada telinga bagian luar.

Hyalue Carilage:

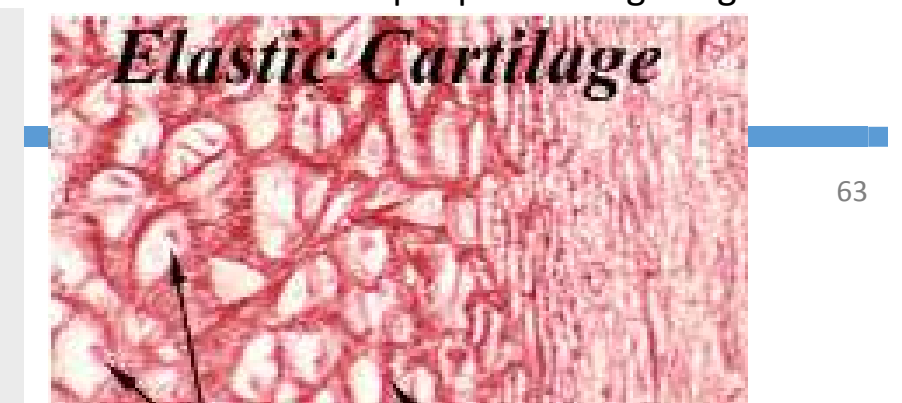




\section{Ligamen (simplay)}

Ligamen adalah suatu susunan serabut yang terdiri dari jaringan ikat keadaannya kenyal dan fleksibel. Ligament mempertemukan kedua ujung tulang dan mempertahankan stabilitas. Contoh ligamen medial, lateral, collateral dari lutut yang mempertahankan diolateral dari sendi lutut serta ligament cruciate anterior dan posterior di dalam kapsul lutut yang mempertahankan posisi anteriorposterior yang stabil. Ligament pada daerah tertentu melengket pada jaringna lunak untuk mempertahankan struktur. Contoh ligament ovarium yang melalui ujung tuba ke peritoneum.

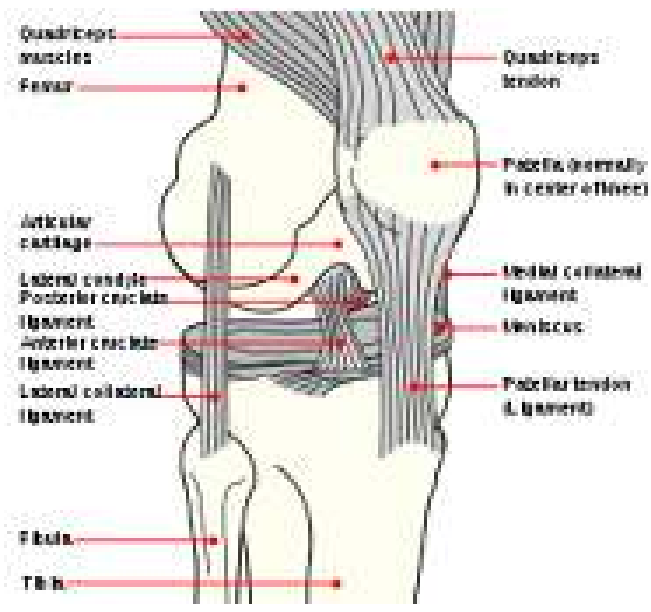

\section{Tendon}

Tendon adalah ikatan jaringan fibrous yang padat yang merupakan ujung dari otot yang menempel pada tulang. Tendon merupakan ujung dari otot dan menempel kepada tulang. Tendon merupakan ekstensi dari serabut fibrous yang bersambungan dengan aperiosteum. Selaput tendon berbentuk selubung dari jaringan ikat yang menyelubungi tendon tertentu terutama pada pergelangan tangan dan tumit. Selubung ini bersambungn dengan membrane sinovial yang menjamin pelumasan sehinggga mudah bergerak.

\section{E. Fascia}

Fascia adalah suatu permukan jaringan penyambung longgar yang didapatkan langsung di bawah kulit, sebagai fascia superficial atau sebagai pembungkus tebal, jaringan penyambung fibrous yang membungkus otot, saraf dan pembuluh darah. Yang demikian disebut fascia dalam.

\section{F. Bursae}


Bursae adalah kantong kecil dari jaringna ikat di suatu tempat dimana digunakan di atas bagian yang bergerak. Misalnya antara tulang dan kulit, tulang dan tendon, otototot. Bursae dibatasi membrane sinovial dan mengandung caiaran sinovial. Bursae merupakan bantalan diantara bagian-bagian yang bergerak seperti olekranon bursae terletak antara prosesus olekranon dan kulit.

\section{G. Persendian}

Sendi adalah tempat pertemuan dua atau lebih tulang. Tulang-tulang ini dipadukan dengan berbagai cara misalnya dengan kapsul sendi, pita fibrosa, ligamen, tendon, fasia atau otot. Dalam membentuk rangka tubuh, tulang yang satu berhubungan dengan tulang yang lain melalui jaringan penyambung yang disebut persendian. Pada persendian terdapat cairan pelumas (cairan sinofial). Otot yang melekat pada tulang oleh jaringan ikat disebut tendon. Sedangkan, jaringan yang menghubungkan tulang dengan tulang disebut ligamen. Secara structural sendi dibagi menjadi: sendi fibrosa, kartilaginosa, sinovial. Dan berdasarkan fungsionalnya sendi dibagi menjadi: sendi sinartrosis, amfiartrosis, diarthroses.

Secara structural dan fungsional klasifikasi sendi dibedakan atas:

1. Sendi Fibrosa/ sinartrosis

Sendi yang tidak dapat bergerak atau merekat ikat, maka tidak mungkin gerakan antara tulang-tulangnya. Sendi fibrosa tidak mempunyai lapisan tulang rawan dan tulang yang satu dengan lainnya dihubungkan oleh jaringan penyambung fibrosa. contohnya sutura pada tulang tengkorak, sendi kaitan dan sendi kantong (gigi), dan sindesmosis (permukaan sendi dihubungkan oleh membran).

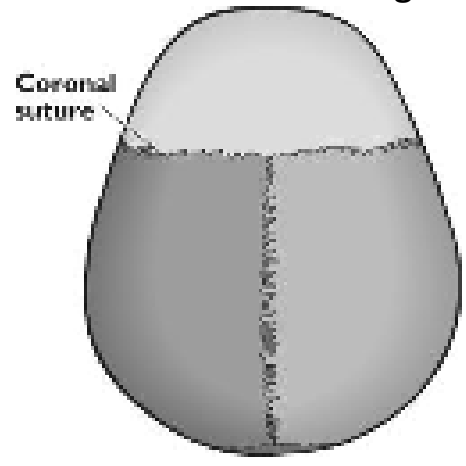

2. Sendi Kartilaginosa/ amfiartrosis

Sendi dengan gerakan sedikit, dan permukaan persendian- persendiannya dipisahkan oleh bahan antara dan hanya mungkin sedikit gerakan. Sendi tersebut ujung-ujung tulangnya dibungkus tulang rawan hyalin, disokong oleh ligament dan hanya dapat sedikit bergerak. Ada dua tipe kartilago :

- Sinkondrosis, Sendi yang seluruh persendianyan diliputi oleh tulang rawan hialin

- Simfisis, Sendi yang tulangnya memiliki hubungan fibrokartilago dan selapis tipis tulang rawan hialin yang menyelimuti permukaan sendi. Contohnya :simfisis pubis (bantalan tulang rawan yang mempersatukan kedua tulang pubis), sendi antara manubrium dan badan sternum, dan sendi temporer / sendi tulang rawan primer yang dijumpai antara diafisis dan epifisis. 


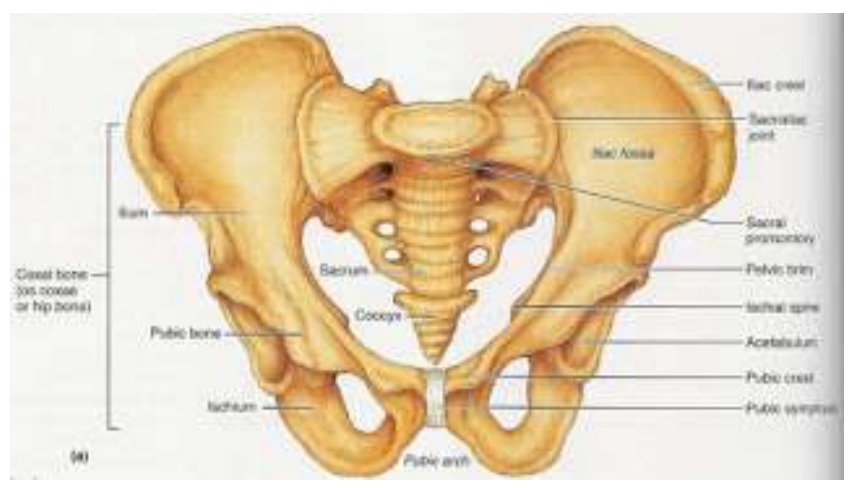

3. Sendi Sinovial/ diarthroses

Sendi tubuh yang dapat digerakkan. Sendi ini memiliki rongga sendi dan permukaan sendi dilapisi tulang rawan hialin. Kapsul sendi terdiri dari suatu selaput penutup fibrosa padat, suatu lapisan dalam yang terbentuk dari jaringan penyambung berpembuluh darah banyak dan sinovium yang membentuk suatu kantong yang melapisi suatu sendi dan membungkus tendon-tendo yang melintasi sendi. Sinovium menghasilkan cairan yang sangat kental yang membasahi permukaan sendi. Caiaran sinovial normalnya bening, tidak membeku dan tidak berwarana. Jumlah yang ditemukan pada tiap-tiap sendi relative kecil 1$3 \mathrm{ml}$. Cairan sinovial bertindak pula juga sebagi sumber nutrisi bagi tulang rawan sendi.

Tulang rawan memegang peranana penting, dalam membagi organ tubuh. Tulang rawan sendi terdi dari substansi dasar yang terdiri dari kolagen tipe II dan proteoglikan yang dihasilkan oleh sel-sel tulang rawan. Proteoglikan yang ditemukan pada tulang rawan sendi sangat hidrofilik, sehingga memungkinkan rawan tersebut mampu menahan kerusakan sewaktu sendi menerima beban berat. Perubahan susunan kolagen dan pembentukan proteoglikan dapat terjadi setelah cedera atau ketika usia bertambah.

Persendian yang bergerak bebas dan banyak ragamnya. Berbagai jenis sendi sinovial yaitu sendi datar / sendi geser, sendi putar, sendi engsel, sendi kondiloid, sendi berporos, dan sendi pelana / sendi timbal balik.Gerak pada sendi ada 3 kelompok utama yaitu gerakan meluncur, gerkan bersudut / anguler, dan gerakan rotasi.

Adapun pergerakan yang dapat dilakukan oleh sendi-sendi adalah fleksi, ekstensi, adduksi, abduksi, rotasi, sirkumduksi dan Pergerakan khusus seperti supinasi, pronasi, inversion, eversio, protaksio.

Sendi diartrosis terdiri dari:

- Sendi peluru

Sendi peluru adalah persendian yang memungkinkan gerakan yang lebih bebas. Sendi ini terjadi apabila ujung tulang yang satu berbentuk bonggol, seperti peluru masuk ke ujung tulang lain yang berbentuk cekungan. Contoh sendi peluru adalah hubungan tulang panggul dengan tulang paha, dan tulang belikat dengan tulang atas. 


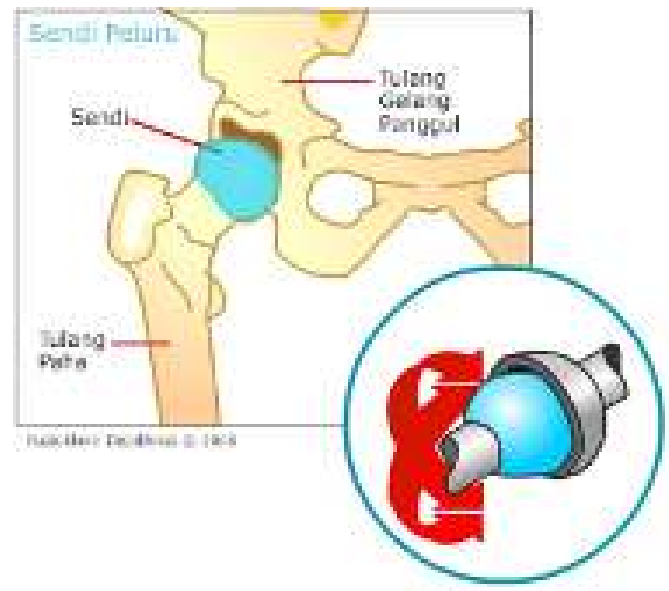

- Sendi engsel

Memungkinkan gerakan melipat hanya satu arah, Persendian yang menyebabkan gerakan satu arah karena berporos satu disebut sendi engsel. Contoh sendi engsel ialah hubungan tulang pada siku, lutut, dan jari-jari.

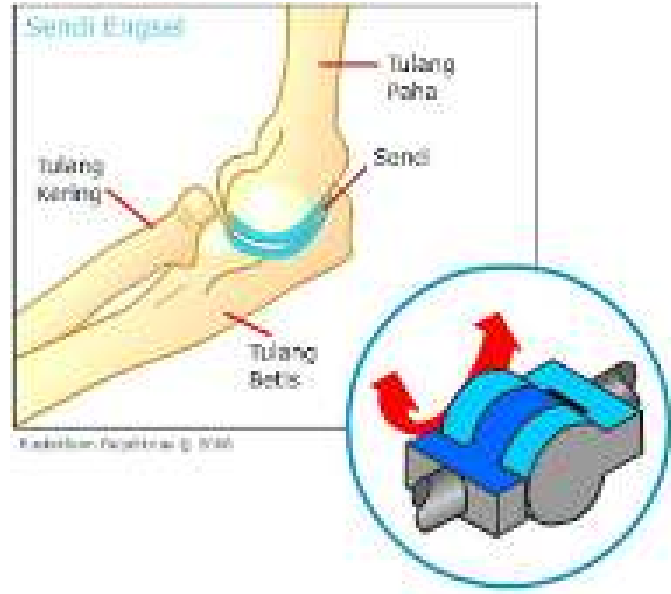

- Sendi pelana

Sendi pelana adalah persendian yang membentuk sendi, seperti pelana, dan berporos dua. Contohnya, terdapat pada ibu jari dan pergelangan tangan Memungkinkan gerakan 2 bidang yang saling tegak lurus. misal persendian dasar ibu jari yang merupakan sendi pelana 2 sumbu.

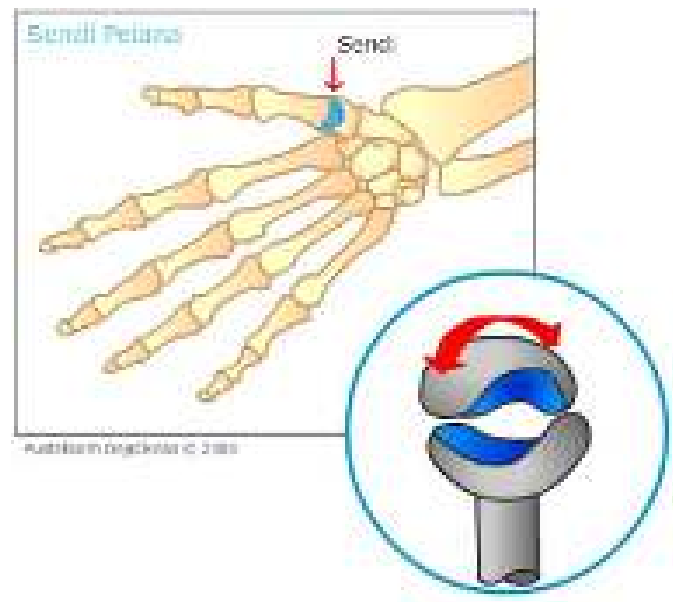

- Sendi pivot 
Memungkinkan rotasi untuk melakukan aktivitas untuk memutar pegangan pintu, misal persendian antara radius dan ulna.

- Sendi peluncur

Memungkinkan gerakan terbatas kesemua arah. Contoh adalah sendi-sendi tulang karpalia di pergelangan tangan

\section{H. Jaringan Penyambung}

Jaringan yang ditemukan pada sendi dan daerah-daerah yang berdekatan terutama adalah jaringan penyambung, yang tersususn dari sel-sel dan subtansi dasar. Dua macam sel yang ditemukan pada jaringan penyambung sel-sel yang tidak dibuat dan tetap berada pada jaringan penyambung, seperti sel mast, sel plasma, limfosit, monosit, leukosit polimorfonuklear. Sel-sel ini memegang peranan penting pada reaksi-reaksi imunitas dan peradangan yang terlihat pada penyakit-penyakit reumatik. Jenis sel yang kedua dalam sel penyambung ini adalah sel yang tetap berada dalam jaringan seperti fibroblast, kondrosit, osteoblas. Sel-sel ini mensintesis berbagai macam serat dan proteoglikan dari substansi dasar dan membuat tiap jenis jaringan pemyambung memiliki susunan sel yang tersendiri.

Serat-serat yang didapatkan didalam substansi dasar adalah kolagen dan elastin. Serat-serat elastin memiliki sifat elastis yang penting. Serat ini didapat dalam ligament, dinding pembuluh darah besar dan kulit. Elastin dipecah oleh enzim yang disebut elastase. 


\section{Otot}

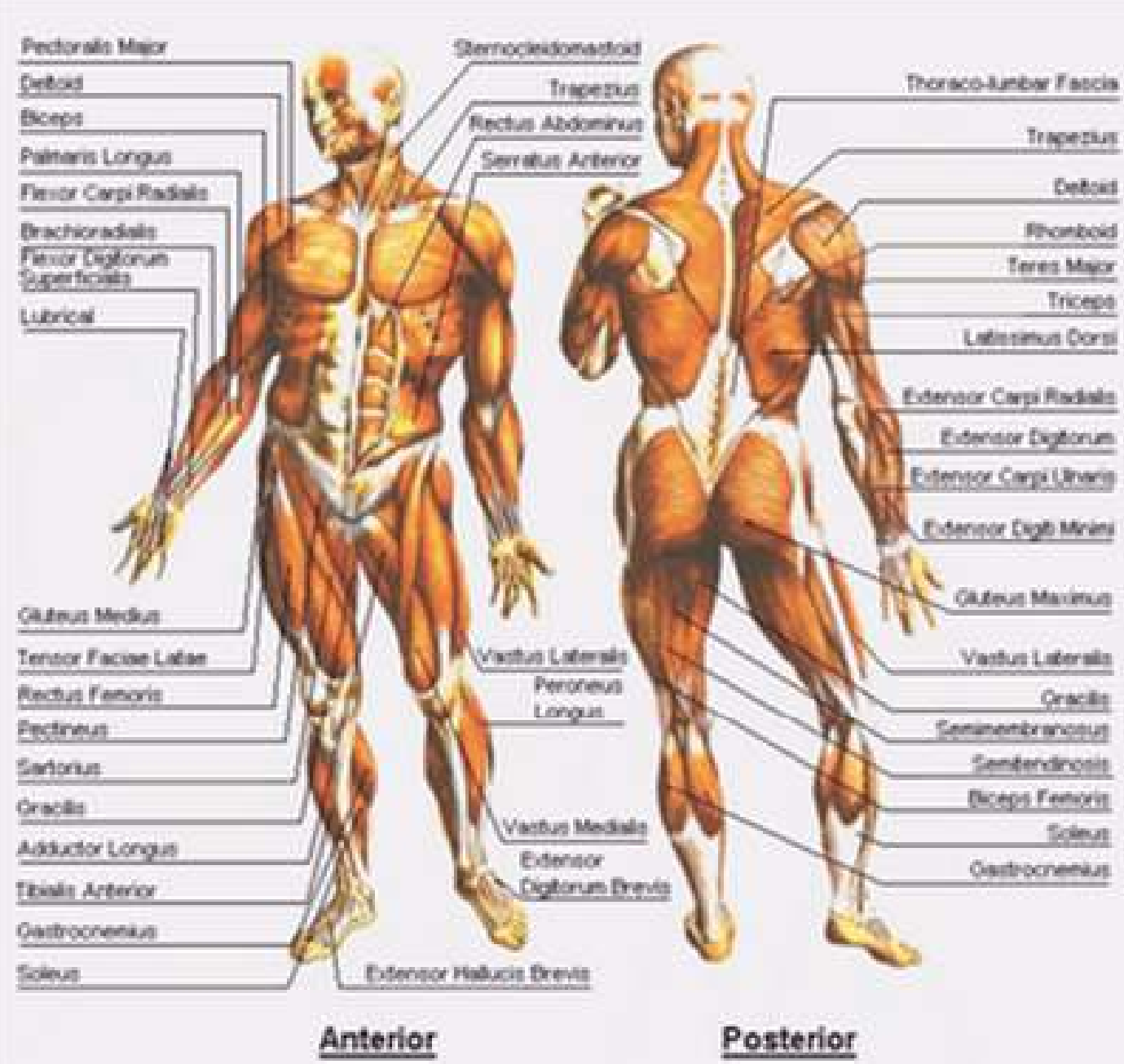

Otot yang melekat pada tulang memungkinkan tubuh bergerak. Kontraksi otot menghasilkan suatu usaha mekanik untuk gerakan maupun produksi panas untuk mempertahankan temperature tubuh. Jaringan otot terdiri atas semua jaringan kontraktil. Menurut fungsi kontraksi dan hasil gerakan dari seluruh bagian tubuh otot dikelompokkan dalam :

1. Otot rangka (striadted / otot lurik).

Terdapat pada system skelet, memberikan pengontrolan pergerakan, mempertahankan postur tubuh dan menghasilkan panas.

2. Otot polos (otot visceral).

Terdapat pada saluran pencernaan, perkemihan, pembuluh darah. Otot ini mendapat rangsang dari saraf otonom yang berkontraksi di luar kesadaran

3. Otot jantung.

Hanya terdapat pada jantung dan berkontraksi di luar pengendalian.

Otot rangka dinamai menurut bentuknya seperti deltoid, menurut jurusan serabutnya seperti rektus abdominis, menurut kedudukan ototnya seperti pektoralis mayor, menurut fungsinya seperti fleksor dan ekstensor. Otot rangka ada yang berukuran panjang, lebar, rata, membentuk gumpalan masas. Otot rangka berkontraksi bila ada rangsang. Energi kontaraksi otot diperoleh melalui pemecahan ATP dan kegiatan calsium. Otot dikaitkan di dua tempat tertentu yaitu : 


\section{Origo}

Tempat yang kuat dianggap sebagai tempat dimana otot timbul

\section{Isersio}

Lebih dapat bergerak dimana tempat kearah mana otot berjalan.

Kontraksi otot rangka dapat terjadi hanya jika dirangsang. Energi kontraksi otot dipenuhi dari pemecahan ATP dan kegiatan kalsium. Serat-serat dengan oksigenasi secara adekuat dapat berkontraksi lebih kuat, bila dibandingkan dengan oksigenasi tidak adekuat. Pergerakan akibat tarikan otot pada tulang yang berperan sebagai pengungkit dan sendi berperan sebagai tumpuan atau penopang.

Masalah yang berhubungan dengan system ini mengenai semua kelompok usia, masalah pada system musculoskeletal tidak mengancam jiwa tetapi berdampak pada kativitas dan produktivitas penderita.

\section{Ciri-Ciri Sistem Otot}

Otot memendek jika sedang berkontraksi dan memanjang jika sedang berelaksasi. Kontraksi otot terjadi jika otot sedang melakukan kegiatan. Relaksasi otot terjadi jika otot sedang beristirahat. Dengan demikian otot memiliki 3 karakter, yaitu:

- Kontrakstilitas, yaitu serabut otot berkontraksi dan menegang, otot menjadi lebih pendek dari ukuran semula.

- Ekstensibilitas, yaitu serabut otot memiliki kemampuan untuk menegang melebihi panjang otot saat rileks (memanjang).

- Elastisitas, yaitu serabut otot dapat kembali ke ukuran semula setelah berkontraksi atau meregang. 
Sistem Pencernaan merupakan saluran yang menerima makanan dari luar dan mempersiapkannya untuk diserap oleh tubuh dengan jalan proses pencernaan (pengunyahan, penelanan dan pencampuran) dengan enzim dan zat cair yang terbentang mulai dari mulut (oris) sampai anus.

Fungsi utama system ini adalah untuk menyediakan makanan, air, dan elektrolit bagi tubuh dari nutrient yang dicerna sehingga siap diabsorpsi. Pencernaan berlangsung secara mekanik dan kimia, dan meliputi proses - proses berikut :

a. Ingesti adalah masuknya makanan ke dalam mulut. Pemotongan dan penggilingan makanan dilakukan secara mekanik oleh gigi.

b. Peristaltik adalah gelombang kontraksi otot polos involunter yang menggerakkan makanan tertelan melalui saluran pencernaan.

c. Digesti adalah hidrolisis kimia (penguraian) molekul besar menjadi molekul kecil sehingga absorpsi dapat berlangsung.

d. Absorpsi adalah pergerakan produk akhir pencernaan dari lumen saluran pencernaan ke dalam sirkulasi darah dan limfatik.

e. Egesti (defekasi) adalah proses eliminasi zat - zat sisa yang tidak tercerna.

Agar makanan dapat dicerna secara optimal dalam saluran pencernaan, harus memiliki persediaan air, elektrolit dan makanan yang terus menerus, untuk ini dibutuhkan :

a. Pergerakan makanan melalui saluran pencernaan

b. Sekresi getah pencernaan

c. Absorpsi hasil pencernaan air dan elektrolit

d. Sirkulasi darah melalui organ gastrointestinal yang membawa zat yang akan diabsorpsi

e. Pengaturan semua fungsi oleh sistem saraf hormon.

Susunan saluran pencernaan terdiri dari oris, faring, esofagus, ventrikulus, intestinum minor yang terbagi menjadi duodenum, ileum, jejenum, usus mayor yang terbagi menjadi kolon asendens, transversum, desendens, sigmoid, rektum dan anus. Organ yang menghasilkan getah cerna meliputi kelenjar ludah, kelenjar getah lambung, kelenjar hati dan kelenjar pankreas.

Fungsi 4 dinding saluran pencernaan:

a. Tunika mukosa (lapisan dalam) : diliputi lapisan sel epitel, menyekresi mukus dan melepaskan hormon krdalam darah, membentuk kelenjar eksokrin untuk menyekresi asam, enzim, air dan ion-ion kedalam lumen, melindungi saluran pencernaan terhadap gesekan makanan yang keras.

b. Tunika submukosa : jaringan ikat kedua sebelah dalam yang dilalui pembuluh darah dan pembuluh limfe yang besar. Cabangnya menembus lapisan mukosa didalam submukosa terdapat suatu jala sel saraf, mempunyai 2 lapisan yaitu otot longitudinal dan obliq.

c. Tunika muskularis (lapisan otot) : kontraksinya menimbulkan gaya mendorong dan memindahkan isis saluran pencernaan, membentuk sistem saraf enterik, membantu mengintegrasikan keaktifan motorik dan sekretorik sistem pencernaan.

d. Tunika serosa (lapisan luar) : jaringan ikat yang mengelilingi saluran pencernaan, lapisannya sangat tipis disebut juga peritonium, menyekresi cairan serosa untuk membasahi dan mencegah gesekan organ pencernaan dan alat dalam sekitarnya. 


\section{Mulut}

Mulut adalah permulaan saluran pencernaan. Rongga mulut dibatasi oleh beberapa bagian, yaitu sebelah atas oleh tulang rahang dan langit-langit (palatum), sebelah kiri dan kanan oleh otot-otot pipi, serta sebelah bawah oleh rahang bawah. mulut dilapisi membran mukosa yang terdiri atas epitelium skuamosa berlapis yang berisi sedikit kelenjar penyekresi mukus. Bagian mulut di antara gusi dan pipi adalah vestibula (vestibulum oris) dan sisanya adalah rongga mulut (kavitas oris propia). Palatum membentuk langit-langit mulut dan terdiri atas palatum durum (langit-langit keras) di bagian anterior dan palatum molle (langit-langit lunak) di bagian posterior. Uvula adalah lipatan otot melengkung yang ditutupi membran mukosa dan berada tergantung di tengah ujung bebas palatum molle. Ada 2 jenis pencernaan didalam rongga mulut yaitu pencernaan mekanik dan pencernaan kimiawi.

Fungsi rongga mulut:
a. Mengerjakan pencernaan pertama dengan jalan mengunyah
b. Untuk berbicara
c. Bila perlu, digunakan untuk bernafas.

\section{Pipi dan Bibir}

Pipi adalah daerah berdaging pada wajah di bawah mata dan di antara hidung dan telinga kiri atau kanan. Pipi membentuk dinding lateral pada mulut manusia dan menyentuh tulang pipi di bawah mata. Lapissan luar pipi dilapisi oleh kulit dan bagian dalam oleh jaringan epitel yang mengandung selaput lendir. Otot pengunyah memanjang dari maksila ke mandibula sifatnya lebih elastis, muskulus buksinator membentuk basis otot pipi.

Bibir adalah bagian tubuh yang terlihat di mulut manusia maupun pada beberapa binatang. Bibir yang lembut, bergerak, dan berfungsi sebagai pembukaan untuk asupan makanan dan dalam artikulasi suara dan bicara. Bibir manusia adalah organ indra sentuhan. Pipi dan bibir mengandung otot-otot yang diperlukan dalam proses mengunyah dan bicara, disebelah luar pipi dan bibir diselimuti oleh kulit dan disebelah dalam diselimuti oleh selaput lendir (mukosa). Pada kavum oris terdapat 2 buah palatum :

a. Palatum durum : tersusun oleh tulang keras, terbentuk oleh prosesus palatinus maksilaris dan os palatum, berbentuk melengkung, dilapisi lapisan mukosa dan periosteum, bagian belakang terdapat banyak kelenjar palatina.

b. Palatum mole : bagian depan bersatu dengan palatum durum, belakang membentuk sebagian ismus fausium dan berhubungan dengan faring, terdiri dari jaringan fibrosa dan jaringan mukosa. Pada bagian tengah terdapat uvula.

\section{Gigi}

Gigi adalah bagian keras yang terdapat di dalam mulut dari banyak vertebrata. Mereka memiliki struktur yang bervariasi yang memungkinkan mereka untuk melakukan banyak tugasAkar dari gigi tertutup oleh gusi. Gigi memiliki struktur pelindung yang disebut email gigi, yang membantu mencegah lubang di gigi. Pulpa dalam gigi menciut dan dentin terdeposit di tempatnya.

Struktur gigi walaupun berbentuk gigi beragam, gigi memiliki struktur yang serupa dan terdiri atas : mahkota (bagian yang menonjol dari gusi), akar (bagian yang melekat didalam 
tulang), dan leher (bagian yang sedikit sempit dimana mahkota muncul dengan akar). Di bagian tengah gigi terdapat rongga pulpa yang mengandung pembuluh darah, pembuluh limfe dan saraf, serta dentin yang merupakan substansi yang menyerupai gading yang keras diluar dentin mahkota, terdapat enamel yaitu lapisan tipis dari substansi yang keras. Akar gigi, ditutupi oleh semen, merupakan substansi yang menyerupai tulang dan menjaga agar gigi tetap di rongganya.

Sebagian besar arteri yang memperdarahi gigi adalah cabang arteri maksilaris. Vena yang memperdarahi adalah vena jugularis internal. Saraf yang mempersarafi gigi bagian atas adalah cabang saraf maksilaris dan gigi bawah dipersarafi oleh cabang saraf mandibularis. Kedua saraf ini merupakan cabang dari saraf trigeminus.

Bagian-bagian gigi : Mahkota gigi atau corona, merupakan bagian yang tampak di atas gusi. Terdiri atas:

a. Lapisan email, merupakan lapisan yang paling keras.

b. Tulang gigi (dentin), di dalamnya terdapat saraf dan pembuluh darah.

c. Rongga gigi (pulpa), merupakan bagian antara corona dan radiks.

d. Leher gigi atau kolum, merupakan bagian yang berada di dalam gusi.

e. Akar gigi atau radiks, merupakan bagian yang tertanam pada tulang rahang. Akar gigi melekat pada tulang rahang dengan perantaraan semen gigi.

f. Semen gigi melapisi akar gigi dan membantu menahan gigi agar tetap melekat pada gusi. Terdiri atas: Lapisan semen, merupakan pelindung akar gigi dalam gusi. Gusi, merupakan tempat tumbuh gigi.

Berdasarkan bentuk dan fungsinya gigi dapat dibedakan menjadi:

a. Gigi seri atau Incisivi (I) yang memiliki fungsi untuk menggigit dan memotong.

b. Gigi taring atau Caninus $(C)$ yang memiliki fungsi untuk menyobek.

c. Gigi geraham dapat dibedakan menjadi gigi geraham kecil atau Premolar $(P)$ dan gigi geraham besar atau Molar $(M)$ yang memiliki fungsi mengunyah dan melumatkan makanan.

Gigi ada dua macam :

a. Sulung, Mulai tumbuh pada anak usia anak anak umur $6-7$ bulan. Lengkap pada umur 2,5 tahun jumlahnya 20 buah disebut juga gigi susu, terdiri dari : 8 buah gigi seri, (dens insisivus), 4 buah gigi taring (dens kaninus) dan 8 buah gigi geraham (molare).

b. Gigi Tetap (gigi permanen) tumbuh pada umur 6-18 tahun, jumlahnya 32 buah, terdiri dari : 8 buah gigi seri, (dens insisivus), 4 buah gigi taring (dens kaninus) 18 buah gigi geraham (molare)dan 12 buah gigi geraham (premolare).

\section{Lidah}

Lidah adalah struktur muskular yang berada di dasar mulut. Bagian dasar lidah melekat pada tulang hioid dan frenulum pada dasar mulut. Permukaan superior berisi epitelium skuamosa berlapis, dengan banyak papila (tonjolan kecil). Papila berisi reseptor sensori (ujung saraf khusus) yang berfungsi sebagai indera pengecap yang berada di kuncup pengecap. dibagi atas tiga bagian : 
a. Pada pangkal lidah (radiks lingua) yang belakang terdapat epiglottis yang berfungsi untuk menutup jalan napas pada waktu kitamenelan makanan, supaya makanan jangan masukn ke jalan napas.

b. Panggal lidah (dorsum lingua) terdapat putting-putting pengecap atau ujung saraf pengecap. Frenulum lingua merupakan selaput lender yang terdapat pada bagian bawah kira kira di tengah, jika lidah digerakan ke atas, tampak selaput lendir. Flika sublingual terdapat di sebelah kiri dan kanan frenulun lingua, di sini terdapat pula lipatan selaput lendir. Pada pertengahan flika sublingual initerdapat saluran dari grandula parotis, submaksilaris dan glandula sublingualis. Bagian lidah yang berperan dalam mengecap rasa makanan adalah papilla. Ada tiga jenis papila yaitu :

1) Papila sirkumvalate : berjumlah 8-12 dan disusun dalam bentuk $V$ terbalik di dasar lidah serta berukuran paling besar.

2) Papila fungiformis : berada diujung lidah dan jumlahnya lebih banyak daripada papila valate

3) Papila filiformis : merupakan papila terkecil dan paling banyak berada di permukaan dua pertiga anterior lidah Lidah diperdarahi oleh cabang lingual dari arteri karotid eksternal dan dialiri vena lingual yang bergabung dengan vena jugularis internal. Saraf yang mempersarafi lidah adalah saraf hipoglossal, cabang lingual dan saraf mandibula, dan saraf facial serta glosofaringeal yang merupakan saraf pengecap. Lidah berperan penting dalam menguyah, menelan, bicara, dan mengecap.

c. Ujung lidah (apeks lingua) membantu mengembalikan makanan, ptoses berbicara, merasakan makanan yang dimakan, dan membantu proses menelan.

Fungsi Lidah :

a. Untuk membersihkan gigi serta rongga mulut antara pipi dan gigi

b. Mencampur makanan dengan ludah

c. Untuk menolak makanan dan minuman kebelakang

d. Untuk berbicara

e. Untuk mengecap manis, asin dan pahit

f. Untuk merasakan dingin dan panas

\section{Kelenjar Ludah}

Saliva (ludah) merupakan sekresi dari kelenjar ludah dan sebagian kecil kelenjar penyekresi mukus dan mukosa oral. Sekitar 1,5 liter saliva dihasilkan setiap hari dan terdiri atas air, garam mineral, enzim (amilase salivarious), mukus lisozim, imunoglobulin, dan faktor pembekuan darah. Sekresi saliva berada di bawah kendali saraf otonom. Stimulasi parasimpatik menyebabkan vasodilatasi dan sekresi air ludah yang banyak disertai sedikit kandungan enzim dan substansi organik. Stimulasi simpatik menyebabkan vasokontriksi dan sekresi air ludah yang sedikit dan kaya materi organik, khususnya dari kelenjar submandibula. Sekresi reflek terjadi saat terdapat makanan di dalam mulut dan reflek dapat dengan mudah semakin terfasilitasi sehingga penglihatan, bau, bahkan pikiran tentang makan dapat menstimulasi aliran saliva.

Arteri yang memperdarahi kelenjar ludah berasal dari cabang arteri karotis eksternal dan vena yang mengalir di kelenjar ludah berasal dari vena jugularis eksterna. Kelenjar ludah (salliva) melepaskan sekresinya ke saluran (duktus) yang mengarah ke mulut. Tiga pasang duktus utama ini adalah kelenjar parotis, kelenjar submandibula, dan kelenjar sublingual. 
a. Kelenjar parotis

Kelenjar ini berada disisi kiri dan kanan wajah tepat dibawah meatus akustik eksternal. Tiap kelenjar memiliki satu duktus parotis yang bersambung ke mulut yang berada sejajar dengan gigi geraham atas kedua. Cairan ludah hasil sekresinya dikeluarkan melalui duktus stesen kedalam rongga mulut melalui satu lubang dihadapannya gigi molar kedua atas. Saliva yang disekresikan sebanyak 25-35\%.

b. Kelenjar submandibula

Kelenjar ini berada disisi kiri dan kanan wajah dibawah sudut rahang. Dua duktus submandibula bersambung dengan dasar mulut, satu ditiap sisi frenulum. Saliva yang disekresikan sebanyak 3-5\%.

c. Kelenjar sublingual

Semua kelenjar diselubungi kapsul fibrosa. Kelenjar ini terdiri atas sejumlah lobulus yang disusun oleh kantong-kantong kecil (acini) yang dilapisi sel. Saliva yang disekresikan sebanyak 60-70\%.

Saliva berfunfsi :

a. Membantu pencernaan polisakarida secara kimia.

Saliva mengandung enzim amilase yang menginisiasi penghancuran gula komplek, termasuk pati, mereduksinya menjadi disakarida maltose. Nilai $\mathrm{pH}$ optimum untuk kerja amilase salivarious adalah 6,8 (sedikit asam). Rentang $\mathrm{pH}$ saliva 5,8- 7,4, bergantung pada kecepatan aliran saliva; semakin tinggi keepatan aliran maka semakin tinggi $\mathrm{pH}$ (basa). Kerja enzim berlanjut saat menelan hingga berakhir di lambung yang mengeluarkan asam kuat $(\mathrm{pH} 1,5-1,8)$ dari getah lambung yang menguraikan amilase.

b. Lubrikasi makanan.

Makanan kering masuk ke mulut dilembabkan dan lubrikasi oleh saliva sebelum diubah menjadi bolus dan siap untuk ditelan. Membersihkan dan melubrikasi. Aliran saliva yang adekuat dapat membersihkan, melembabkan dan melembutkan mulut. Saliva membantu mencegah kerusakan membran mukosa dari makanan yang kasar dan abrasif.

c. Pertahanan tubuh non-spesifik. Lisozim, imunoglobulin, dan faktor pembekuan (koagulasi) menyerang mikroba.

d. Pengecapan.

Kuncup pengecapan hanya dapat distimulasi oleh zat kimia dalam larutan sehingga makanan kering hanya menstimulasi indera pengecap setelah bercampur dengan saliva.

\section{Faring}

Merupakan penghubung antara rongga mulut dan kerongkongan. Berasal dari bahasa yunani yaitu Pharynk. Didalam lengkung faring terdapat tonsil (amandel) yaitu kelenjar limfe yang banyak mengandung kelenjar limfosit dan merupakan pertahanan terhadap infeksi, disini terletak bersimpangan antara jalan nafas dan jalan makanan, letaknya dibelakang rongga mulut dan rongga hidung, didepan ruas tulang belakang. Ke atas bagian depan berhubungan dengan rongga hidung, dengan perantaraan lubang yang disebut ismus fausium.

Tekak terdiri dari tiga bagian : 
a. Bagian superior (bagian yang sama tinggi dengan hidung) disebut Nasofaring. Pada nasofaring bermuara tuba yang menghubungkan tekak dengan ruang gendang telinga.

b. Bagian media (bagian yang sma tinggi dengan mulut) disebut Orifaring

c. Bagian inferior nasofaring yang disebut Laringofaring.

Menelan (deglutisic), jalan udara masuk ke bagian depan terus ke leher bagian depan sedangkan jalan makanan masuk ke belakang dari jalan napas dan di depan dari ruas tulang belakang. Makanan melewati epiglottis lateral melalui resus piriformis masuk ke esophagus tanpa membahayakan jalan udara. Gerakan menelan mencegah masuknya makanan ke jalan udara, pada waktu yang sama jalan udara ditutup sementara. Permulaan menelan, otot mulut dan lidah berkontraksi secara bersamaan.

Dinding faring terdiri atas tiga lapisan yaitu :

a. Lapisan dalam dilapisi oleh membrane mukosa yang berupa epithelium skuamosa berlapis, terus melapisi faring hingga ke pangkal mulut dan esofagus.

b. Lapisan tengah terdiri atas jaringan fibrosa yang semakin menipis di bagian ujung bawahnya dan mengandung pembuluh limfe dan saraf.

c. Lapisan luar terdiri atas sejumlah otot involunter yang terlibat dalam proses menelan. Saat makanan menelan mencapai faring, proses menelan tidak lagi di bawah kendali otot Volunter.

Arteri yang memperdarai faring adalah beberapa cabang arteri fasialis. Vena yang mengalir keluar faring berasal dari vena fasialis dan vena jugularis interna. Saraf yang mempersarafi faring berasal dari pleksus faringeal yang berisi saraf simpatik dan parasimpatik. Saraf parasimpatik yang mempersarafi faring berasal dari saraf glosofaringeal dan vagus, sedangkan saraf simpatik yang mempersarafi faring berasal dari ganglia servikalis.

\section{Peristiwa Menelan}

Selama proses menelan, otot-otot diaktifkan secara berurutan dan secara teratur dipicu dengan dorongan kortikal atau input sensoris perifer. Begitu proses menelan dimulai, jalur aktivasi otot beruntun tidak berubah dari otot-otot perioral menuju kebawah. Jaringan saraf, yang bertanggung jawab untuk menelan otomatis ini, disebut dengan pola generator pusat. Batang otak, termasuk nucleus tractus solitarius dan nucleus ambiguus dengan formatio retikularis berhubungan dengan kumpulan motoneuron kranial, diduga sebagai pola generator pusat.

Deglutition adalah tindakan menelan, dimana bolus makanan atau cairan dialirkan dari mulut menuju faring dan esofagus ke dalam lambung. Deglutition normal adalah suatu proses halus terkoordinasi yang melibatkan suatu rangkaian rumit kontraksi neuromuskuler valunter dan involunter dan dan dibagi menjadi bagian yang berbeda: (1) oral, (2) faringeal, dan (3) esophageal. Masing-masing fase memiliki fungsi yang spesifik, dan, jika tahapan ini terganggu oleh kondisi patologis, gejala spesifik dapat terjadi.

a. Fase Oral

Fase persiapan oral merujuk kepada pemrosesan bolus sehingga dimungkinkan untuk ditelan, dan fase propulsif oral berarti pendorongan makanan dari rongga mulut ke dalam orofaring. Prosesnya dimulai dengan kontraksi lidah dan otot-otot rangka mastikasi. Otot bekerja dengan cara yang berkoordinasi untuk mencampur bolus 
makanan dengan saliva dan dan mendorong bolus makanan dari rongga mulut di bagian anterior ke dalam orofaring, dimana reflek menelan involunter dimulai.

Cerebellum mengendalikan output untuk nuklei motoris nervus kranialis V (trigeminal), VII (facial), dan XII (hypoglossal). Dengan menelan suatu cairan, keseluruhan urutannya akan selesai dalam 1 detik. Untuk menelan makanan padat, suatu penundaaan selama 5-10 detik mungkin terjadi ketika bolus berkumpul di orofaring.

b. Fase Faringeal

Fase faringeal adalah sangat penting karena, tanpa mekanisme perlindungan faringeal yang utuh, aspirasi paling sering terjadi pada fase ini. Fase inimelibatkan rentetan yang cepat dari beberapa kejadian yang saling tumpang tindih. Palatum mole terangkat. Tulang hyoid dan laring bergerak keatas dan kedepan. Pita suara bergerak ke tengah, dan epiglottis melipat ke belakang untuk menutupi jalan napas. Lidah mendorong kebelakang dan kebawah menuju faring untuk meluncurkan bolus kebawah. lidah dubantu oleh dinding faringeal, yang melakukan gerakan untuk mendorong makanan kebawah.

Sphincter esophageal atas relaksasi selama fase faringeal untuk menelan dan dan membuka oleh karena pergerakan os hyoid dan laring kedepan. Sphincter akan menutup setelah makanan lewat, dan struktur faringeal akan kembali ke posisi awal. Fase faringeal pada proses menelan adalah involunter dan kesemuanya adalah reflek, jadi tidak ada aktivitas faringeal yang ter jadi sampai reflek menelan dipicu. Reflek ini melibatkan traktus sensoris dan motoris dari nervus kranialis IX (glossofaringeal) dan X (vagus).

\section{c. Fase Esophageal}

Pada fase esophageal, bolus didorong kebawah oleh gerakan peristaltik. Sphincter esophageal bawah relaksasi pada saat mulai menelan, relaksasi ini terjadi sampai bolus makanan mecapai lambung. Tidak seperti shincter esophageal bagian atas, sphincter bagian bawah membuka bukan karena pengaruh otot-otot ekstrinsik. Medulla mengendalikan reflek menelan involunter ini, meskipun menelan volunter mungkin dimulai oleh korteks serebri. Suatu interval selama 8-20 detik mungkin diperlukan untuk kontraksi dalam menodorong bolus ke dalam lambung.

\section{Muntah}

Muntah adalah cara saluran pencernaan bagian atas membuang isinya sendiri bila usus teriritasi, teregang, atau terangsang berlebih. Rangsangan ini menyebabkan muntah dapat terjadi pada setiap bagian saluran pencernaan, meskipun pada gaster dan intestinum memberikan rangsangan yang paling kuat.

Muntah adalah suatu refleks kompleks yang diperantarai oleh pusat muntah di medula oblongata otak. Implus-implus aferen berjalan ke pusat muntah sebagai aferen vagus dan simpatis. Impuls-impuls aferen berasal dari lambung atau deudonum dan muncul sebagai respon terhadap distensi berlebihan atau iritasi, atau kadang-kadang sebagai respons terhadap rangsangan kimiawi oleh emetik (bahan yang menyebabkan muntah). Hipoksia dan nyeri juga dapat merangsang muntah melalui pengaktivan pusat muntah. Muntah juga dapat terjadi perangsangan langsung bagian-bagian otak yang terletak dekat dengan pusat 
muntah di otak. Obat-obat tertentu mencetuskan muntah dengan mengaktifkan pusat ini, yang disebut chemo receptor trigger zone, yang terletak di dasar ventrikel keempat. Muntah yang timbul akibat perubahan gerak yang cepat diperkirakan berlangsung melalui trigger zone ini. Pengaktivan chemoreceptor tigger zone dapat secara langsung mencetuskan muntah, atau secara tidak langsung melalui pengaktivan -pusat muntah. Input dari pusat-pusat otak yang lebih tinggi di korteks dan peningkatan tekanan interkranium (TIK) juga dapat merangsang muntah, mungkin dengan secara langsung merangsang pusat muntah. Muntah proyektil terjadi apabila pusat muntah dirangsang secara langsung, dan sering oleh peningkatan TIK.

Apabila refleks muntah telah diawali di pusat muntah, maka muntah tersebut terjadi melalui pengaktivan beberapa saraf kranialis ke wajah dan kerongkongan serta neuronneuron motorik spinalis ke otot abdomen dan diafragma. Eksitasi jaras-jaras ini menyebabkan timbulnya respons muntah yang terkoordinasi. Gejala-gejala tertentu biasanya mendahului muntah, termasuk mual, takikardia, dan berkeringat.

Ketika pusat muntah cukup dirangsang, efek yang terjadi secara bertahap adalah:
a. inspirasi dalam,
b. mengangkat os hyodeus dan laring untuk mendorong sfingter eosofageal terbuka,
c. menutup glotis, dan
d. mengangkat palatum molle untuk menutup nares posterior

\section{Esofagus}

Panjang esophagus sekitar $25 \mathrm{~cm}$ dan diameternya sekitar $2 \mathrm{~cm}$ serta berada di bidang median toraks di depan kolum vertebra yang berada di belakang trakea dan jantung. Bagian atas esogafus berhubungan dengan faring dan tepat pada bagian bawahnya berhubungan dengan diafragma yang bersatu dengan lambung. Esofagus berada di antara serat otot diafragma di belakang tendon sentral pada vertebra torasik ke 10. Sebelum esophagus berhubungan dengan lambung, di bagian diafragma, esophagus membentuk lengkung ke atas, dengan demikian membentuk sudut runcing yang mencegah regurgitasi (aliran balik) isi lambung ke esophagus.

Ujung atas dan bawah esophagus ditutup oleh sfingter. Sfingter krikofaringeal atas atau esophagus atas mencegah udara melalui esophagus saat inspirasi dan aspirasi isi esophagus. Saat tekanan intra abdomen meningkat (misal saat inspirasi dan defekasi), tonus sfingter esophagus bawah meningkat. Terdapat empat lapis jaringan esophagus. Karena hampir semua bagian esophagus berada di dalam toraks, lapisan luar esophagus, lapisan adventisia, berisi jaringan fibrosa elastic yang meletakkan esophagus pada struktur di sekelilingnya. Sepertiga bagian proksimal esophagus dilapisi oleh epithelium skuamosa berlapis, sepertiga distal dilapisi oleh epithelium kolumnar, dan sepertiga bagian tengah dilapisi oleh campuran kedua lapisan epithelium tersebut.

Regio torasik dipersarafi terutama oleh pasangan arteri esophagus, yang merupakan cabang dari aorta torasik. Regio abdomen dipersarafi oleh cabang dari arteri frenik dan cabang arteri seliaka kiri. Dari region torasik, vena keluar menuju ke vena azigos dan hemiazigos. Di region abdomen, vena ke luar menuju ke vena lambung kiri di mana 
terdapat pleksusu di ujung distal yang berhubungan dengan drainase vena ke atas dan bawah, yaitu sirkulasi vena porta dan umum.

10. Lambung

Lambung atau gaster (ventrikulus) merupakan bagian dari saluran yang dapat mengembang paling banyak terutama di daerah epigaster. Lambung terdiri dari bagian atas fundus uteri berhubungan dengan esophagus melalui orifisium pilorik, terletak di bawah diafragma di depan pancreas dan limpa, menempel di sebelah kiri fundus uteri. Organ yang bebatasan dengan Lambung :

Anterior : lobus kiri hati dan diding abdomen anterior.

Posterior : aorta abdominal, pangkreas, limpa, ginjal kiri, dan kelenjar adrenal.

Superior : diafragma, esophagus, dan lobus kiri hati.

Inferior : kolon transversum dan usus halus.

Kiri : diafragma dan limfa

Kanan : hati dan duodenum

Lambung berhubungan dengan esophagus dibagian sfingter kardiak dan berhubungan dengan duodenum di sfingter pylorus, lambung memiliki dua lengkung (kurvatur) : kurvatur minor yang berada di bagian permukaan posterior lambung yang menurun ke dinding posterior esophagus dan kurvatur mayor yang berada di permukaan anterior lambung.

Lambung dibagi menjadi beberapa bagian :

a. Fundus ventrikuli : bagian yang menonjol keatas, terletak sebelah kiri osteum kardiak, biasanya berisi gas. Pada batas dengan esofagus terdapat katup sfingter kardiak

b. Korpus ventrikuli : merupakan segitiga osteum kardia yaitu suatu lekukan pada bagian bawah kurvatura minor, merupakan bagian utama dari lambung.

c. Antrum pilorus : bagian lamubung berbentuk tabung, mempunyai otot yang tebal membentuk sfingter pilorus, muara bagian distal berlanjut ke duodenum.

d. Kurvatura mayor : terbentang pada sisi kiri ostium kardia melalui fundus menuju kekanan sampai pilorus inferior, lebih panjang dari kurvatura minor, dihubungkan dengan kolon transversum oleh omen tum mayor lipatan ganda dari peritonium.

e. Kurvatura minor : tempat esofagus bagian abdomen masuk ke lambung. Pada bagian ini terdapat orifisium pilorus, tidak mempunyai sfingter khusus hanya berbentuk cincin membuka dan menutup. Dengan kontraksi dan relaksasi, osteum dapat tertutup oleh lipatan membran mukosa dan serat otot pada dasar esofagus.

Otot Imbung terdiri dari tiga lapisan serat otot polos : lapisan luar - serat longitudinal, lapisan tengah - serat sirkular, dan lapisan dalam - serat obliq. Susunan otot ini memungkinkan karakteristik gerakan mengocok/mengaduk pada lambung dan gerakan peristalsis. Otot sirkular merupakan oto terkuat di antrum pylorus dan sfingter pylorus. Saat lambung kosong, membrane mukosa yang melapisi cenderung masuk kedalam lipatan longitudinal atau rungae, dan saat lambung penuh, rugae tampak seperti beludru yang memiliki permukaan halus. Banyak kelenjar lambung yang berada dipermukaan membrane mukosa. Kelenjar ini berisi sel-sel khusus yang menyekresikan getah lambung masuk ke lambung. 
Arteri yang memperdarahi lambung adalah arteri lambung kiri, suatu cabang arteri seliaka, arteri lambung kanan, dan arteri gastroepiploik. Vena yang memperdarahi lambung samadengan vena yang menuju vena porta.

Fungsi lambung :

a. Mekanis : menyimpan, mencampur dengan sekret lambung, mengeluarkan kimus ke dalam usus halus. Pendorongan makanan terjadi karena gerakan peristaltik tiap 20 detik.

b. Kimiawi : bolus dalam lambung akan dicampur dengan asam lambung dan enzim tergantung jenis makanan :

1) Pepsi, fungsinya memecah putih telur menjadi asam amino (albumin dan peptone)

2) Asam garam $(\mathrm{HCl})$, fungsinya mengasamkan makanan dan membuat suasana asam pada pepsinogen menjadi pepsin.

3) Renin, fungsinya sebagai ragi yang membekukan susu dan membentuk kasein dan dari karsinogen (karsinogen dan protein susu)

4) Lapisan lambung, jumlahnya sedikit memecah lemak menjadi asam lemak yang marangsang sekresi getah lambung.

c. Bakterisid : oleh asam lambung

d. Membantu proses pembentukan eritrosit. Menghasilkan zat faktor intrinsik dan ekstrinsik dari makanan, membentuk zat yang disebut anti-anemik berguna uktuk pertukaran eritrosit yang disimpan dalam hati.

\section{Sekresi Getah Lambung dan Gerakan Lambung}

Ukuran lambung bervariasi sesuai denagn volume makanan didalamnhya, sekitar1,5 liter atau lebih pada orang dewasa. Saat makanan ditelan, makanan terakumulasi di lapisan lambung. Makanan kadang tersisa di bagian fundus. Kontraksi otot lambung meliputi gerakan mengaduk-aduk yang menghancurkan bolus dan mencampurkan bolus dengan getah lambung, serta gerakan peristalsis yang mendorong isi lambung ke pylorus. Saat lambung aktif (ada makanan di lambung) sfingter pylorus menutup. Kontraksi peristaltic dari antrium pylorus yang kuat akan mendorong kime, setelah isi lambung cukup cair, akan mengalir melalui pylorus ke duodenum dalam semburan yang kecil.

Stimulasi parasimpatik meningkatkan motilitas lambung dan sekresi getah lambung, sedngkan stimulasi simpatik memiliki efek yang berlawanan dengan dengan parasimpatik. Sekitar 2 liter getah lambung disekresi setiap hari dengan kelenjar sekretorik khusus di mukosa. Getah lambung berisi air dan garam mineral yang disekresi oleh kelenjar lambung, mucus ynag disekresi sel goblet di dalam kelenjar dan di permukaan lambung, asam hidroklorida $(\mathrm{HCL})$ dan factor intrinsic yang disekresi oleh sel parietal di kelenjar lambung, serta precursor enzim aktif: pepsinogen yang disekresi oleh sel utama dikelenjar.

Fungsi getah lambung adalah sebagai pencair makanan yang telah ditelan dan lebih lanjut, penyekresi asam klorida (mengasamkan makanan dan menghentikan kerja amylase saliva, membunuh mikroba yang tertelan mulut, memberikan suasana asam yang diperlukan pepsin untuk pencernaan yang efektif), pengaktivsi pepsinogen menjadi pepsin (bekerja efektif pada $\mathrm{pH} 1,5-3,5$ ), sebagai factor intrinsik (protein) yang diperlukan untuk absorbsi vitamin b12 di ileum, dan penyekresi ukus yang mencegah 
cidera mekanik dinding lambung serta mencegah cidera kimia dengan bekerja sebagai barier antara dinding lambung dan getah lambung yang korosif.

Terdapat 3 fase sekresi getah lambung

a. Fase sefalik

aliran getah lambung ini terjadi sebelum makanan mencapai lambung dan karena stimulasi reflek saraf vagus (parasimpatik) yang diinisiasi oleh penglihatan, bau, atau pengecapan makanan. Saat saraf Vagus dipotong (vagotomi), fase sekresi lambung ini berhenti. Stimulasi simpatik, misal saat kondisi emosi, juga menghambat aktifitas lambung.

b. Fase gastric

saat distimulasi oleh keberadaan makanan, sel eteroendokrin di anrum pylorus dan duodenum menyekresi gastrin, suatu hormone yang langsung melalu darah yang beredar. Gastrin, yang berda dalam darah beredar ke lambung, merangsang kelenjr gastric untuk menghasilkan getah lambung lebih banyak. Dengan cara sekresi gatah pencernaan ini trus berlangsung hingga selesainya penghancuran makanan di lambung dan akhir fase sefalik. Sekresi gastrin di supresi saat ph di antrum pylorus turun hingga sekitar 1,5 .

c. Fase intestinal (usus)

saat sebagian isi lambung yang dicerna mencapai usus halus, dua hormone yaitu sekretin dan kolesistokinin, dihasilkan oleh sel indokrin di mukosa usus. Hormone ini menurunkan sekresi getah lambung dan menghambat motilitas lambung. Dengan mepercepat pengosongan lambung, kime di duodenum menjadi semakin tercampur rata dengan empedu dan getah pamgkreas, fase sekresi lambung ini paling saat individu mengonsumsi makanan tinggi lemak.Kecepatan pengosongan lambung bergantung pada jenis makanan yang dimakan.pemgosongan karbohidrat di lambung berlangsung dalam 2-3 jam, sedangkan protein dan lemak memerlukan waktu yang lebih lama lagi.

\section{Usus Halus}

Usus halus merupakan bagian dari sistem pencernaan makanan yang berpangkal pada pilorus dan berakhir pada sekum. Panjangnya sekitar 6 meter, merupakan saluran pencernaan yang paling panjang tempat proses pencernaan dan absorpsi pencernaan.

Bentuk dan susunannya berupa lipatan- lipatan mmelingkar. Makanan dalam usus halus dapat masuk karena adanya gerakan dan memberikan permukaan yang lebih halus. Banyak jonjot-jonjot tempat absorbsi dan memperluas permukaanya. Pada ujung dan pangkalnya terdapat katup. Terletak dalam rongga abdomen dan dikelilingi oleh usus besar.

Lapisan usus halus dari dalam keluar :

a. Tunika mukosa : banyak terdapat lipatan berbentuk filia sirkularis dan vili intestinal yang selalu bergerak karena pengaruh hormon jaringan villi kinin, banyak mengandung pembuluh darah dan limfe. Terjadi penyerapan lemak yang sudah diemulsi. 
b. Tunika propia : bagian dalam tunika mukosa, terdapat jaringan limfoid dalam bentuk sendiri dan berkelompok. Kumpulan ini disebut plak peyeri, tanda khas dari ileum. Pada penyakit typus, plak peyeri ini sering meradang karena invasi kuman salmonella

c. Tunik submukosa : terdapat anyaman pembuluh darah dan saraf simpatis

d. Tunika muskularis : terdiri dari lapisan otot sirkuler dan longitudinal, diantaranya trdapat anyaman serabut saraf yang disebut fleksus mesentrikus auebbachi

e. Tunika serosa : meliputi seluruh jejenum dan iileum.

\section{Bagian dari Usus Halus}

a. Duodenum : melengkung seperti kuku kuda, pada lengkungan terdapat pankreas. Bagian kanan tempat bermuaranya saluran empedu dan pankreas yang dinamakan papipa vateri. Dindingnya mempunyai lapisan mukosa banyak mengandung kelnjar brunner yang memproduksi getah intestinum.

b. Jejenum : panjangnya 2-3 meter berkelok-kelok pada sebelah kiri atas usus halus dengan perantaraan lipatan peritonium berbentuk kipas. Jejenum lebih lebar, dindingnya lebih tebal dan banyak mengandung pembuluh darah.

c. Ileum : ujung batas antara jejenum dan ileum tidak jelas panjangnya sekitar 4-5 meter. Terletak sebelah kanan bawah berhubungan dengan sekum. Diperkuat oleh sfingter dan dilengkapi sebuah katup valvula sekalis berfungsi untuk mencegah cairan dalam kolon asendens masuk kembali dalam ileum.

Mukosa usus halus merupakan permukaan epitel yang halus, melalui lipatan mukosa dan mikrovilli memudahkan pencernaan dan absorbsi, dibentuk oleh mukosa dan submukosa yang dapat memperbesar permukaan usus halus.

Pada mukosa usus halus terdapat sekresi :

a. Kelenjar brunner (duodenum) : menghasilkan mukus dan larutan $\mathrm{NaHCO} 3$ dengan $\mathrm{pH}$ 7,5 tidak mengandung enzim dan melindungi mukosa duodenum dari keaktifan asam lambung dan pepsin. Sekresi kelenjar ini dirangsang oleh saraf nervus vagus

b. Kelenjar intestinal : menghasilkan mukus enterikus, enzim enteropeptidase, disakarida, peptidase, fosfatase alkalis, mukus, cairan isotonik dengan $\mathrm{pH} 7$.

\section{Absorpsi Usus Halus}

Absorpsi makanan yang sudah dicerna berlangsung dalam usus halus melalui 2 saluran pembuluh kapiler darah dan saluran limfe sebelah dalam permukaan vili. Vili keluar dari dinding usus, bersentuhan dengan makanan yang sudah cair dan lemak yang sudah diabsopsi ke dalam lakteal.

a. Karbohidrat

Produk yang dihasilkan terutama dalam bentuk gula sederhana yang mudah larut dalam air mudah diangkut ke seluruh sel-sel guna penyediaan energi. Nilai energi karbohidrat adalah $4 \mathrm{kkal}$ per gram. Berdasarkan gugus penyusun gulanya dapat dibedakan menjadi monosakarida, disakarida, dan polisakarida.

b. Protein

Protein adalah suatu senyawa organik yang tersusun oleh unsur-unsur karbon, hidrogen, oksigen, nitrogen dan terkadang juga mengandung unsur fosfor dan belerang. Komponen dasar dari senyawa protein adalah asam amino yang dibedakan menjadi tiga golongan yaitu: asam amino esensial, semiesensial, dan non esensial.

c. Lemak 
Lemak merupakan senyawa organik majemuk, terdiri dari unsur karbon (C), hidrogen $(\mathrm{H})$, oksigen $(\mathrm{O})$ dan terkadang tersusun oleh fosforus $(\mathrm{P})$ dan nitrogen $(\mathrm{N})$. Lemak diserap oleh tubuh dalam bentuk gliserol dan asam lemak.

d. Air dan elektrolit

Air tergolong sebagai zat makanan karena air selalu diperlukan sebagai bahan pelarut dalam metabolisme tubuh. Air tidak menghasilkan energi. Air yang dibutuhkan oleh tubuh tergantung berat badan, jenis kelamin, aktivitas, dan suhu lingkungan.

Di Usus Halus Tiap harinya sekitar $1500 \mathrm{ml}$ getah usus disekresi oleh kelenjar usus halus. Getah ini mengandung air, mucus, dan garam mineral. pH getah usus biasanya antara 7,8 dan 8,0 . Saat kime asam melalui usus halus, kime bercampur dengan getah penkreas, empedu, dan getah usus, dan berhubungan dengan enterosit vili. Di usus halus, pencernaan secara kimia terjadi (tripsinogen, kimotripsinogen, prokarboksipeptidase). Getah pancreas bersifat basa $(\mathrm{pH} 8)$ karena mengandung banyak ion bikarbonat, yang bersifat basa dalam larutan. Saat isi asam lambung bercampur dengan getah pancreas dan empedu, selain itu $\mathrm{pH}$ meningkat antara 6 dan 8. Pada $\mathrm{pH}$ ini, enzim pankreatik yaitu amylase dan lipase bekerja dengan efektif.

Sekresi getah pancreas distimulasi oleh sekretin dan CCK, yang dihasilkan oleh sel endokrin di dinding duodenum. Keberadaan kime asam lambung di duodenum, menstimulasi produksi hormone ini. e. Fungsi getah pancreas adalah sebagai berikut :

a. Pencernaan protein

Tripsinogen dan kimotripsinogen merupakan prekusor enzim inaktif yang diaktivasi oleh enterokinase, suatu enzim di mikrovili, yang mengubah prekusor ini menjadi enzim tripsin dan kimotripsin. Enzim ini mengubah polipeptida menjadi tripeptida, dipeptida, dan asam amino. Penting bahwa enzim-enzim ini diproduksi sebagai prekusor inaktif dan hanya diaktivasi saan tiba di duodenum, jika tidak, enzim ini akan merusak pancreas.

b. Pencernaan karbohidrat

Amylase pankreatik mengubah semua polisakarida (pati) yang dapat dicerna menjadi heksosa glukosa, fruktosa, monosakarida, galaktosa dan sebagian kecil pentosa.

c. Pencernaan lemak Lipase mengubah lemak menjadi asam lemak dan gliserol. Untuk membantu kerja lipase, garam empedu mengemulsi lemak, dengan cara memperkecil globulin dan meningkatkan area permukaannya. Empedu, yang disekresi oleh hati, tidak dapat masuk ke duodenum saat sfingter hepatopangkreatik menutup. Oleh karena itu, empedu melalui duktus sistikus hati mengalir menuju kandung empedu dimana empedu disimpan. Empedu memiliki pH sekitar 8 dan antara 500-1000 ml empedu disekresi setiap harinya. Empedu terdiri atas air, garam empedu, mucus, pigmen empedu, khususnya bilirubin, dan kolesterol.

\section{Kontraksi Usus Halus}

Dikoordinasi oleh suatu gelombang depolarisasi usus halus yang bergerak dari otot polos sirkuler duodenum ke arah kaudal. Frekuensi tertinggi duodenum 11-13/menit, ileum 9/menit. Jenis kontraksi usus halus : 
a. Segmentasi : gerakan paling sering, tergantung slow ware, bertujuan untuk mencampur kimus dengan liur pencernaan dan mendekatkan kimus dengan permukaan absorpsi mukosa

b. Peristaltik : kontraksi otot sirkuler dengan kecepatan $2-3 \mathrm{~cm} /$ detik untuk mendorong kimus kearah usus besar.

c. Kontraksi muskularis mukosa: tidak teratur 3 kali/menit, mencampur isi lumen.

d. Sfingter ileosekalis : melemas bila peristaltik ilium sampai di sfingter.

e. Refleks gastroileal : peningkatan fungsi sekresi dan motorik lambung. Kimus masuk kedalam sekum melalui refleks panjang.

Fungsi usus halus:

a. Menyekresi cairan usus

b. Menerima cairan empedu dan pankreas

c. Menerima zat-zat makanan yang sudah di cerna untuk diserap melalui kapiler-kapiler darah dan saluran-saluran limfe.

d. Mencerna makanan : menyerap protein dalam bentuk asam amino, karbohidrat diserap dalam bentuk monosakarida

e. Menggerakkan kandungan usus.

\section{Usus Besar}

Panjang usus Besar sekitar 1,5-1,7 meter, yang memanjang dari sekum difosa iliaka kanan hingga rectum dan saluran Anus dipelvis. Diameter lumennya sekitar 5-6,5 cm, lebih besar daripada lumen usus halus. Usus besar membentuk lengkung di sekitar usus halus yang tergulung. Usus besar di bagi menjadi : sekum,kolon asenden, kolon desenden, kolon transversum, kolon sigmoid, rectum, dan saluran Anus.

\section{Bagian dari usus besar :}

a. Sekum merupakan bagian pangkal kolon dan merupakan area buntu di depan inferiornya dan bersambung dengan kolon asenden di bagian superior. Tepat di bawah dua katup ileosekum bersambung dengan ileum. Panjangnya sekitar $6 \mathrm{~cm}$.

b. Kolon asenden kolon ini berjalan menuju ke atas, yakni dari sekum ke bagian kolon setinggi hati dimana kolon membentuk garis lengkung yang tajam di bagian kiri fleksur hepatika untuk membentuk kolon transversum. Panjangnya $13 \mathrm{~cm}$.

c. Kolon transversum : panjangnya $38 \mathrm{~cm}$. Kolon ini merupakan lengkung kolon yang melintang di rongga abdomen didepan duedenum dan lambung menuju area limfs dimana kolon ini membentuk fleksur splenik. Kolon desenden kolon ini berjalan menuju ke bawah rongga abdomen kemudian melengkung menuju garis tengah.

d. Kolon desendens : panjangnya sekitar $25 \mathrm{~cm}$, terletak bawah abdomen bagian kiri dari atas ke bawah dari depan fleksura lienalis sampai didepan ilium kiri bersambung dengan sigmoid dan dibelkang peritonium.

e. Kolon sogmoid kolon ini membentuk suatu lengkung berbentuk huruf $\mathrm{S}$ di pelvis yang berlanjut kebawah membentuk rektum. Panjangnya sekitar $40 \mathrm{~cm}$.

Rektum merupakan bagian kolon yang sedikit melebar dan memiliki panjang sekitar $13 \mathrm{~cm}$. Bagian pangkal rektum berbatasan dengan kolon sigmoid dan bagian ujungnya berbatasan dengan saluran anus. 
Saluran anus merupakan saluran pendek yang panjangnya $3,9 \mathrm{~cm}$ pada orang dewasa dan memanjang dari rektum hingga bagian eksterior dua otot sfingter mengendalikan anus yaitu sfingter eksternal dan internal.

\section{Fungsi usus besar}

a. Absorbsi : isi ileum yang melalui katup ileosekum ke sekum adalah cairan, meskipun sebagian air telah di absorbsi di usus halus garam mineral vitamin dan sebagian obat juga diabsorbsi di kapiler darah dari usus besar

b. Aktifitas mikrobial usus besar merupakan tempat kolonisasi dari banyak bakteri tertentu yang mensintesis vit $\mathrm{K}$ dan asam folat, bakteri ini meliputi escherichia coly, enterobakter aerogenes, dll.

c. Gerakan massa : gerakan peristaltis dengan interval yang panjang terjadi pada kolon tranversum mendorong isi usus besar ke kolon desenden dan sigmoid kombinasi stimulus dan respon disebut reflex gastrokolik.

d. Defekasi : melibatkan kontraksi invonlunter otot rektum dan relaksasi spingter anal internal. Kontraksi otot abdomen dan peningkatan tekanan intra abdomen (valsava manuver) dapat membantu proses defekasi (pengeluaran Feces).

\section{Gerakan Kolon}

Gerakan kolon terdiri dari:

1. Gerakan mencampur: Pada tiap kontraksi kira-kira $2,5 \mathrm{~cm}$, otot sirkuler kolon mengerut kadang-kadang dapat menyempitkan lumen dengan sempurna. Gabungan otot sirkuler dan longitudinal menyebabkan bagian usus besar tidak terangsang, mengembung keluar, merupakan kantong yang disebut Haustraktion. Dalam waktu 30 detik kontraksi haustral akan bergerak dengan lambat ke arah anus. Beberapa menit kemudian timbul kontraksi haustral kedua yang baru dekat tempat semula tetapi tidak pada tempat yang sama. Dengan cara ini feses perlahan-lahan didekatkan ke permukaan dan secara progresif terjadi penyerapan air.

2. Gerakan Mendorong: Pada kolon terjadi gerakan yang disebut Mass Movement, mendorong feses ke arah anus. Gerakan ini timbul beberapa kali sehari, biasanya sesudah makan pagi. Pada mulanya pergerakan terjadi pada bagian kolon yang terserang kemudian kolon distal tempat kontraksi kira-kira $20 \mathrm{~cm}$, berkontraksi serentak sebagai satu kesatuan mendorong bahan feses ke bagian yang lebih distal. Mass Movement dapat terjaid pada tiap bagian kolon tranversum dan kolon desendens. Apabila sejumlah feses telah didorong ke dalam rektum, timbul keinginan untuk defekasi. Mass Movement yang snagat kuat akan mendorong feses melalui rektum dan anus keluar. Hal ini jarang terjadi karena kontraksi tonik yang terus menerus pada sfingter ani internus dan ekstrenus. 


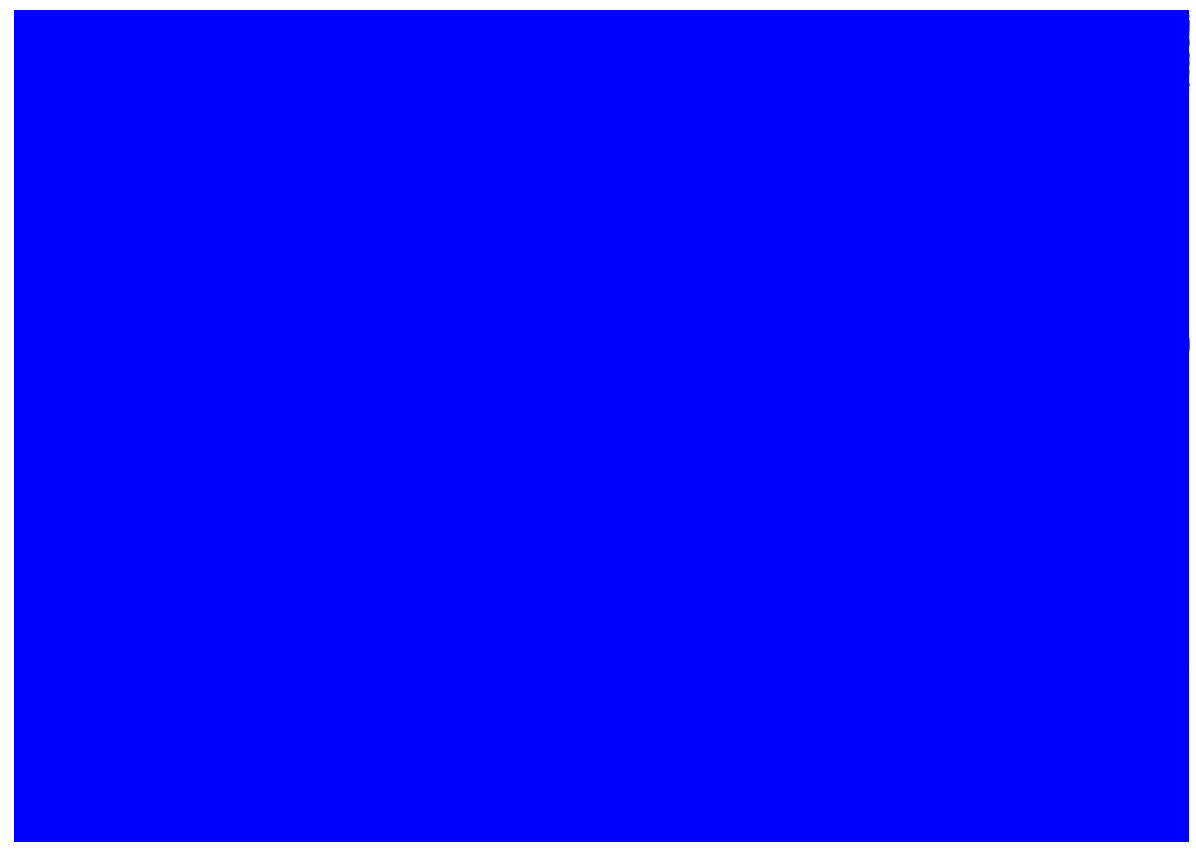

\section{REKTUM DAN ANUS}

Rektum adalah sebuah ruangan yang berawal dari ujung usus besar (setelah kolon sigmoid) yang menghubungkan intestinum mayor dengan naus sepanjang $12 \mathrm{~cm}$, dan berakhir di anus. Biasanya rektum ini kosong karena tinja disimpan di tempat yang lebih tinggi, yaitu pada kolon desendens. Jika kolon desendens penuh dan tinja masuk ke dalam rektum, maka timbul keinginan untuk buang air besar (BAB). Orang dewasa dan anak yang lebih tua bisa menahan keinginan ini, tetapi bayi dan anak yang lebih muda mengalami kekurangan dalam pengendalian otot yang penting untuk menunda BAB. Rektum terdiri dari dua bagian:

1. Rektum propia: Bagian yang melebar disebut ampula rekti. Jika ampiula rekti terisis makanan Akan timbul hasrat defekasi.

2. Pars analis rekti: Sebelah bawah ditutupi oleh serat-serat otot polos (M.Sfingter ani internus) dan serabut otot lurik ( $M$,sfingter ani eksternus). Kedua otot ini berperan pada waktu defekasi tunika mukosa rektum banyak mengandung pembuluh darah. Jaringan mukosa dan jaringan otot membentuk lipatan disebut kolumna rektalis. Bagian bawah kolumna rektalsi terdapat pembuluh darah V.rektalis (V.Hemoroidalis superior, V.Hemoroidalis inferior) Sering terjaid pelebaran atau varises yang disebut Hemoroid (Wasir).

Anus merupakan lubang di ujung saluran pencernaan, dimana bahan limbah keluar dari tubuh. Sebagian anus terbentuk dari permukaan tubuh (kulit) dan sebagian lannya dari usus. Suatu cincin berotot (sfingter ani) menjaga agar anus tetap tertutup.

Anus adalah bagian dari saluran pencernaan yang menghubungkan rektum dengan dunia luar (udara luar). Terletak di dasar pelvis bagian posterior dari peritoneum. Dindingnya diperkuat oleh 3 otot sfingter yaitu:

- Sfingter ani internus (sebelah atas), bekerja tidak menurut kehendak.

- Sfingter levator ani, bekerja juga tidak menurut kehendak.

- ani eksternus (sebelah bawah), bekerja sesuai kehendak 
Defekais adalah hasil refleks apabila bahan feses amsuk ke dalam rektum. Dinding rektum akan meregang menimbulkan impuls aferens yang dislurkan melalui pleksus mesenterikus dan menimbulkan gelombang peristaltik pada kolon desndens. Kolon sigmoid mendorong feses ke arah anus. Apabila gelombang peristaltik sampai anus, sfingter ani internus dihambat dan sfingter ekstrenus melemas sehingga terjadi defekasi.

Orang normal dapat mencegah defekasi sampai waktu dan tempat yang sesuai dengan refleks defekasi, hilang beberapa menit dan timbul kembali sampai beberapa jam. Pada bayi baru lahir refleks defekasi berjalan secara ototmatis dan mengosongkan usus besar bagian bawah.

\section{PROSES PENCERNAAN}

\section{PENGATURAN SARAF}

Kebanyakan refleks $\mathrm{GI}$ dimulai oleh sejumlah rangsangan di lumen:

1. Regangan dinding oleh isi lumen

2. Osmolaritas kismus atau konsentrasi zat yang terlarut

3. Keasamamn kimus (konsntrasi) ion $\mathrm{H}$.

4. Haisl pencernaan karbohidrat, lemak dan protein (monosakarida, asam lemak, peptida dar asam amino).

Sinyai diulai oleh rangsangan tersebut di atas dan bekerja terhadap mekanoresseptor, osmoreseptor dan kemoreseptor serta refleks yang memengaruhi efektor lapsan otot di dalam dinding saluran GI dan kelenjar eksokrin yang menyekresi bahan-bahan dalam lumen. Reseptor maupun efektor reflesk tersebut terdapat di dalam sistem pencernaan. Refleks ini mempertahankan kondisi optimal untuk penecernaan dan absorpsi melalui mekanisme umpan balik negatif.

Sistem saraf intrinsik dalam bentuk dua pleksus saraf, yaitu pleksus mienterikus dan pleksus submukosa, terdiri dari neuron yang membentuk hubungan sinaps dengan neoron lain dalam pleksus berakhir pada otot polos dan kelenjar.

Sistem saraf ekstrinsik adalah serat saraf bagian simpatiks dan parasimpatis. Sistem saraf otonom masuk ke dalam saluran GI mengadakan sinaps dengan neuron dalam pleksus melalui jalur saraf ini. Sususnan saraf pusat (SSP) dapat memengaruhi keaktifan motorik dan sekretorik saluran GI. Ada dua jenis jalur refleks saraf yang menghubungkan suatu rangsangan:

1. Refleks jarak pendek dari reseptor melalui pleksus saraf ke sel sektor.

2. Refleks jauh,dari resptor melalui saraf eksterna (ekstrinsik) ke susunan saraf pusat kembal ke pleksus saraf dan sel efektor denagn perantara saraf otonom. 


\section{PENGATURAN HORMONAL}

Hormon ini dieksresikan dari dinding usus halus, ila disuntikkan pada hewan percobaan menyeabbkan sekresi liur pankreas dengan kandungan bikarbonat yang tinggi. Hormon GI dinamakan Sekretin. Rangsangan bberbagai bahan kimia dalam kimus menyebabkan dilepaskannya hormon di permukaan basal yang kemudian berdifusi ke dalam kapiler.

Fungsi hormon pencernaan

\begin{tabular}{|c|c|c|c|}
\hline HORMON & SUMBER & $\begin{array}{c}\text { STIMULASI UTAMA UNTUK } \\
\text { SEKRESI }\end{array}$ & FUNGSI \\
\hline Gastrin & Sel-sel G di aderah lambung & $\begin{array}{l}\text { Protein di lambung Kelenjar } \\
\text { pilorus lambung }\end{array}$ & 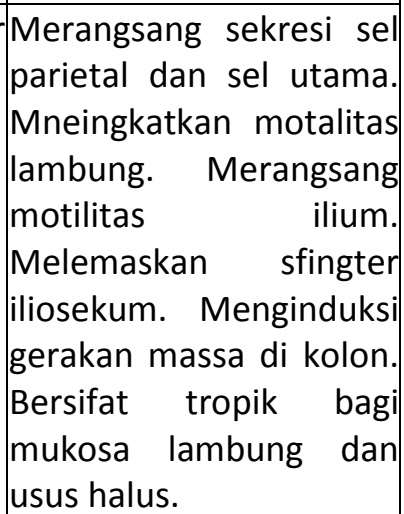 \\
\hline Sekretin & $\begin{array}{l}\text { Sel-sel endokrin dimukosa } \\
\text { duodenum }\end{array}$ & $\begin{array}{l}\text { Nutrien di lumen duodenum, } \\
\text { terutama produk lemak } \\
\text { dengan tingkat yang lebih } \\
\text { rendah dan produk protein }\end{array}$ & 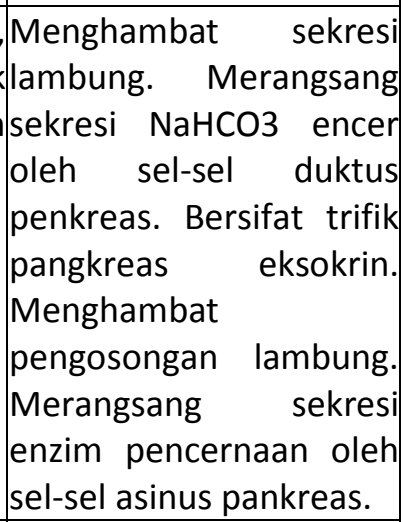 \\
\hline $\begin{array}{l}\text { Inhibitor peptid } \\
\text { gastrik }\end{array}$ & $\begin{array}{l}\text { Sel-sel endokrin di mukosa } \\
\text { duodenum }\end{array}$ & \begin{tabular}{|l} 
Lema \\
hipertonisitas, glukosa dan \\
peregangan diduodenum.
\end{tabular} & 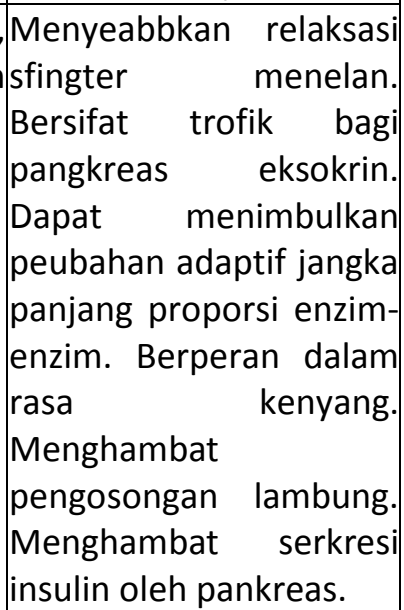 \\
\hline
\end{tabular}

\section{Jenis Hormon}

\section{Gasterin}

Terdapat pada dinding lateral elenjar dan antrum mukosa lambung. Gastrin adalah reseptor yang menjadi perantara respon gastrin terhadap perubahan isi lambung pada mikrovilus mukosa lambung. Efek fisiologi gastrin adalah perangsangan seksresi asam lambung, sekresi pepsin, pertumbuhan mukosa lambung, perangsangan motilitas 
lambung, merangsang seksresi insulin dan glukosa setelah memakan makanan yang mengandung protein.

\section{Kolesistokin-pankreozimin (CCK-PZ)}

Sel didalam mukosa usus halus bagian atas menyekresi satu hormon tunggal yang memiliki dau keaktifan kolesistokinin (CCK) dan pankreozimin (PZ). Selain di dalam sel endokrin usus halus bagian atas CCK juga ditemukan pada saraf ilium distal, kolon, dan neoron di otak terutama bagian korteks dan saraf ditempat lain dalam tubuh. Efek CCk disamping koraski kandung mepedu dan sekresi liur pankreas adalah menimbulkan potensiasi kerja sekretin dalam mermagsang lambung, merangsang pertumbuhan pankreas, meningkakan sekresi emterokinase, dapat meningkatkan motilitas usus halus dan kolon. Rangsnagan yang meningkatkan sekresi CCK adalah sentuhan mukosa usus dengan hasil pencernaan terutama peptida, asam amino dan asam lemak.

\section{Sekretin}

Hormon ini disekresikan oleh sel-sel yang letaknya jauh dalam kelenjar mukosa usus halus bagian atas. Efek sekretin meliputi meningkatkan seksresi bikarbonat oleh sel saluran pankreas dan saluran empedu yang menimbulkan sekrssi liur pankreas encer dan sersifat alkalis, menimbulkan potensiasi efek CCK terhadap sekresi pankreas yang banyak enzimnya, menurunkan sekresi asam lambung, kontraksi sfingter pilorus. Rangsangan yang meningkatkan sekresi sekretin adalah hasil pencernaan protein dan asam yang membasahi mukosa usus halus sebelah atas.

\section{Glukosa Insulinotropik}

Gukosa insulinotropik (GIT) ditemukan dalam mukosa duodenum dan jejenum. Efek (GIT) menghambat sekresi dan motalitas lambung selama fase gastrik, merangsang sekresi insulin, mencerna lemak dan glukosa dalam duodenum, merangsang sekresi elektrolit dan air di usus, menimbulkan dilatasi pembuluh darah tepi, menghambat seresi assm lambung, menimbulkan potensiasi kerja asetilkolin terhadap kelenjar saliva. Hormon lain antara lain motilin, subtansi $P$, somatostatin, histamin, intestinal gatrin, dan serotonin.

\section{Fase Pengendalian Gastro Intestinal}

Pengendalian neural dan hormonal sistem pencernaan dibagi dalam tiga fase :

1. Fase sefalik, dimulai dengan perangsangan reseptor di kepala (sefalik). Rangsangannya berupa penglihatan, pengindu, pengecapan dan mengunyah serta berbagai keadaan emosional. Jlaur aferen untuk perubahan refleks yang ditimbulkan berbagai rangsangan yang melibatkan serat parasimpatis (nervus vagus) dan serat simpatis. Serat ini mengkatifkan neuron dalam pleksus saraf yang ada. Pada gilirannyya memengaruhi kegiatan sekresi dan kontraksi.

2. Fase gastrik, merupakan pengaturan refleks yang dimulai oelh rangsangan yang diberikan pada dinding lambung saat makanan mencapai lambung. Rangsangannya berupa peregangan, asam dan peptida hasil pencernaan parsial protein. Jawaban terhadap rangsnagan tersebut berlangsung dengan perantara pleksuus saraf refleks pendek, saraf ekstrinsik (refleks panjang) dan pelepasan hormon (gastrin).

3. Fase intestinal, dimulai oleh rangsangan dalam lumen usus dengan peregangan, keasamamn, osmolaritas, berbagai hasil pencernaan karbohidrat, lemak, dan protein. Berlangsung dengan perantaraan refleks saraf panjang dan pendek dengan pelepasan 
hormon sekretin dan CCK. Fase ini berlangsung tidak secara berurutan kecuali pada permulaan makan. Selama makan dan periode absorpsi, refleks yang khas untuk ketiga fase ini berlangsung simultan (serentak).

Gerakan fungsional gastrointestinal meliputi gearakan propulsif dan gerakan mencampur:

1. Gerakan propulsif (peristaltik). Gerakan ini menyebabkan makanan bergerak maju sepanjang saluran dengan kecepatan yang sesuia, untuk terjadinya pencernaan dan absorpsi. Peristaltik merupakan sifat yang dimiliki banyak tabung otot polos, sintrum duktus-duktus kelenjar lain di seluruh tubuh, ureter, dan otot lain diseluruh tubuh. Rangsangan umum untuk peristaltik adalah peregangan usus yaitu sejumlah makanan terkumpul pada bagian manapun dalam usus akan merangsang sistem saraf enterik. Untuk menimbulkan kontraski usus yang dapat menimbulkan gerakan peristaltik.

2. Gerakan mencampur. Gerakan mencampur agar isi usus sungguh-sungguh tercampur setiap waktu. Gerakan mencampur sifatnya berbeda pada berbagai bagian saluran pencernaan. Pada beberapa tempat kontraksi peristaltik rerjadi sebagian besar pencampuran. Bila pergerakan maju maka isi usus dihambat oleh sebuah sfingter, sehingga gelombang peristaltik dapat mengaduk isi usus dan menahan dorongan ke depan. Pada saat lain kontraksi lokal terjadi setiap beberapa sentimeter dalam dinding usus. Mengatur motilitas dan pengosongan lambung

\begin{tabular}{|c|c|c|}
\hline FAKTOR & CARA MENGATUR & EFEK \\
\hline $\begin{array}{l}\text { Di dalam lambung volime } \\
\text { kimus }\end{array}$ & $\begin{array}{l}\text { Distensi menimbulkan efek langsung pada } \\
\text { eksitabilitas pada otot polos lambung } \\
\text { serta bekerja melalui pleksus intrinsik } \\
\text { saarf vagus dan gastrin }\end{array}$ & $\begin{array}{l}\text { Peningkatan volume merangsang } \\
\text { motilitas dan pengosongan }\end{array}$ \\
\hline $\begin{array}{l}\text { Derajat keenceran di dala } \\
\text { duodenum }\end{array}$ & $\begin{array}{l}\text { Efek langsung: isi harus berbentuk cai } \\
\text { agar dapat dievakuasi }\end{array}$ & $\begin{array}{l}\text { Peningkatan keenceran mempercepat } \\
\text { pengosongan }\end{array}$ \\
\hline $\begin{array}{|lr|}\text { Adanya lemak, asam, } \\
\text { hipertonisitas } & \text { atau } \\
\text { peregangan } & \\
\end{array}$ & $\begin{array}{l}\text { Memulai refleks enterogastrik atau } \\
\text { memicu pengeluaran enterogastron } \\
\text { (kolesistokinin, sekretin, peptida } \\
\text { inhibitorik lambung }\end{array}$ & $\begin{array}{l}\text { Faktor-faktor } \quad \text { di } \\
\text { menghambat } \\
\text { pengosongan lambung lebih lanjut } \\
\text { sampai di duodenum mengatasi faktor- } \\
\text { faktor yang sudah ada. }\end{array}$ \\
\hline $\begin{array}{l}\text { Di luar sistem pencernaan } \\
\text { emosi }\end{array}$ & Mengubah keseimbangan saraf otonom & $\begin{array}{l}\text { Merangsang atau menghambat } \\
\text { motilitas dan pengosongan }\end{array}$ \\
\hline Nyeri hebat & Meningkatkan aktivitas simpatis & $\begin{array}{lll}\begin{array}{l}\text { Menghambat motilitas dan } \\
\text { pengososngan }\end{array} & \\
\end{array}$ \\
\hline $\begin{array}{l}\text { Penurunan pemakaian } \\
\text { glukosa di hipotalamus }\end{array}$ & Meningkatkan aktivitas vagus & $\begin{array}{l}\text { Merangsang motilitas, disertai oleh } \\
\text { rasa lapar }\end{array}$ \\
\hline
\end{tabular}

\section{PROSES PENCERNAAN}

Daerah khusus peritoneal meliputi:

1. Mesentrium: lipatan peritoneum berlapis ganda yang melekat pada bagian usus ke dinding posterior abdomen, mesentrium terdiri dari usus halus mesokolon (lekukan) transversum dan mesokolon sigmoid

2. Omentum: lapisan peritonium berlapis ganda yang melekat pada lambung, omentum mayus, kurvatura mayor

3. Ligamentum peritoniale: lapisan peritonium berlapis ganda melekat pada dinding abdomen berhubungan dengan tulang, hati, ligamentum falsiformis ke dinding anterior abdomen dan permukaan bawah hati 
4. Sakus minor: bagian dari rongga peritonial yang terletak di sebelah belakang lambung.

5. Rongga peritoneum: merupakan rongga yang terdesak oleh organ abdomen sehingga peritonium parietalis dan viseralis dapat teraba.

\section{Peritoneum}

Peritonium adalah membran tipis, halus dan lembab yang terdapat dalam rongga abdomen dan menutupi organ-organ abdomen. Peritonium merupakan membran serosa yang terdiri dari lapisan jaringan ikat. Peritonial parietal melanjutkan diri ke bawah yang membatasi pelvis dan petonium viseral meliputi organ-organ dalam peritonium.

Ruang potensial yang terdapat antara lapisan parietal dan viseral dinamakan rongga peritoneal, pada pria rongga ini tertutup. Tetapi pada wanita rongga ini terdapat hubungan dengan dunia luar (tuba uterina, uterus dan vagina), mempunyai osteum kecil ujung yang bebas ke dalam kavitas peritoneal, merupakan jalan masuk dari ovum. Peritonial mempunyai dua kantong yitu kantong besar terbentang seluruh abdomen mulai dari diafragma sampai ke pelvis dan kantong kecil terletak dibelakang lambung.

Fungsi sistem pencernaan

\begin{tabular}{|c|c|c|c|c|}
\hline $\begin{array}{c}\text { ORGAN } \\
\text { PENCERNAAN }\end{array}$ & MOTILITAS & SEKRESI & PENCERNAAN & PENYERAPAN \\
\hline $\begin{array}{l}\text { Mulut dan kelenjar } \\
\text { liur }\end{array}$ & Mengunyah & $\begin{array}{l}\text { Saliva, amilase, } \\
\text { mukus, lisosom }\end{array}$ & $\begin{array}{l}\text { Pencernaan } \\
\text { karbohidrat } \\
\text { dimulai }\end{array}$ & $\begin{array}{lr}\text { Makanan } & \text { tidak } \\
\text { diserap hanya } \\
\text { beberapa obat } \\
\text { diserap misalnya } \\
\text { nitrogliserin }\end{array}$ \\
\hline $\begin{array}{ll}\text { Faring } & \text { dan } \\
\text { esofagus } & \\
\end{array}$ & Menelan & Mukus & Tidak ada & Tidak ada \\
\hline Lambung & Tidak ada & $\begin{array}{l}\text { Getah lambung: } \\
\mathrm{HCL} \text {, pepsin, } \\
\text { mukus } \\
\text { Faktor intrinsik } \\
\text { Enzim pencernaan } \\
\text { pankreas }\end{array}$ & $\begin{array}{l}\text { Pencernaan } \\
\text { karbohidrat } \\
\text { berlanjut dikorpus } \\
\text { lambung, } \\
\text { pencernaan } \\
\text { protein dimulai di } \\
\text { atrum lambung }\end{array}$ & $\begin{array}{l}\text { Makanan tidak } \\
\text { diserap, beberapa } \\
\text { zat yang larut } \\
\text { dalam lemak } \\
\text { misalnya alkohol } \\
\text { dan aspirin }\end{array}$ \\
\hline $\begin{array}{l}\text { Pankreas } \\
\text { (eksokrin) }\end{array}$ & Tidak ada & $\begin{array}{l}\text { Tripsin, } \\
\text { kimotripsin, } \\
\text { karboksipeptidase. } \\
\text { Amilase, lipase }\end{array}$ & $\begin{array}{l}\text { Enzim-enzim } \\
\text { pankreas } \\
\text { menyelesaikan di } \\
\text { lumen duodenum }\end{array}$ & Tidak ada \\
\hline Hati & Tidak ada & $\begin{array}{l}\text { Sekresi NaHCO3, } \\
\text { encer pankreas }\end{array}$ & $\begin{array}{l}\text { Empedu tidak } \\
\text { mencerna apapun, } \\
\text { tetapi garam- } \\
\text { garam empedu } \\
\text { mempermudah } \\
\text { pencernaan dan } \\
\text { penyerapan lemak } \\
\text { di lumen } \\
\text { duodenum }\end{array}$ & Tidak ada \\
\hline Usus halus & $\begin{array}{l}\text { Segmentasi } \\
\text { kompleks motilitas }\end{array}$ & $\begin{array}{l}\text { Empedu; garam } \\
\text { empedu }\end{array}$ & $\begin{array}{l}\text { Dalam lumen di } \\
\text { bawah pangkreas } \\
\text { dan empedu. } \\
\text { Pencernaan } \\
\text { karbohidrat dan }\end{array}$ & $\begin{array}{l}\text { Semua nutrien, } \\
\text { sebagian besar } \\
\text { elektrolit dan air }\end{array}$ \\
\hline
\end{tabular}




\begin{tabular}{|l|l|l|l|l|}
\hline & & & $\begin{array}{l}\text { protein berlanjut } \\
\text { dan pencernaan } \\
\text { lemak selesai di } \\
\text { brush border. } \\
\text { Pencernaan } \\
\text { karbohidrat dan } \\
\text { protein selesai }\end{array}$ & \\
\hline Usus besar & $\begin{array}{l}\text { Haustrasi } \\
\text { (pembentukan } \\
\text { lekukan) } \\
\text { pergerakan massa }\end{array}$ & $\begin{array}{l}\text { Sukus enterikus: } \\
\text { mukus, garam, } \\
\text { enzim usus halus } \\
\text { tidak disekresikan } \\
\text { tetapi berfungsi } \\
\text { intersel di brush } \\
\text { border ada } \\
\text { disakaridase dan } \\
\text { amino peptidase, } \\
\text { mukus amilase }\end{array}$ & $\begin{array}{l}\text { Garam dan } \\
\text { mengubah } \\
\text { menjadi feses }\end{array}$ \\
\hline
\end{tabular}

Fungsi peritonium:

1. Tempat melekatnya organ-organ ke dinding abdomen

2. Membentuk pembatas yang halus sehingga mempermudah organ-organ untuk saling bergerak dan tidak saling bergesekan

3. Mempermudah pembuluh-pembuluh darah dan saraf untuk mencapai organ-organ tanpa harus dililit oleh lemak dan mengalami penekanan pada peritonium

4. Tempat kelenjar limfe dan pembuluh darah menutupi area yang terinfeksi dengan omentum mayor

5. Menjaga kedudukan dan mempertahankan hubungan organ terhadap dinding posterior abdomen

Hati Struktur hati

Hati (hepar) merupakan kelenjar aksesori yang terbesar dalam tubuh, berwarna cokelat dan beratnya 1.000-1.800 gram. Hati terletak didalam rongga perut sebelah kanan atas dibawah diafragma, sebagian besar terletak pada regio hipokondria dan regio epigastrium. Hati dibagi menjadi empat lobus:

1. Lobus sinistra, terletak sebelah kiri dari bidang median

2. Lobus dekstra, di sebelah kanan dari bidang median

3. Lobus kaudatus, sebelah bawah bagian ekor

4. Lobus kuadratus, dibelakang berbatas dengan pars pilorika, ventrikula dan duodenum superior

Permukaan hati dibedakan atas:
1. Fascies superior
2. Fascies inferior
3. Fascies posterior
4. Fascies inferior lobus sinistra hepatis
5. Fascies inferior lobus dekstra
6. Fascies superior 
7. Fascies posterior (bagian belakang) tidak ditutupi peritonium, berhubungan dengan diafragma, terdapat sebuah lekuk sebelah kanan vena kava inferior di atas infresio renalis disebut infresio suprarenalis 


\section{FISIOLOGI PENCERNAAN}

\section{Pembuluh darah dan persyarafan}

Pembuluh darah hati berasal dari arteri siliaka menuju ke kanan membentuk lipatan peritonium di depan vena portae, bercabang menjadi arteri hepatika portae dan duktus kholedukus, bercabang menjadi arteri gastrika menuju kurvatura minor gaster dan baranstomosis dengan arteri gastrika sinistra. Kemudian arteri hepatika propia, bercabang menjadi A. Hepatika dekstra bercabang bercabagng masuk kandung empedu arteri sistika dan A. Hepatika sinistra masuk ke dalam hati. Aliran pembuluh darah balik hepar dikumpulkan dalam vena hepatika yang keluar dari permukaan belakang disebelah kranial hepar bermuara ke vena kava inferior.

Hati banyak menghasilkan cairan limfe sekitar sepertiga sampai setengah cairan limfe dalam tubuh. Pembuluh limfe meninggalkan hati masuk ke dalam kelenjar limfe. Dalam porta hepatis pembuluh aferen berjalan ke nodi limfatisi seliaka, beberapa pembuluh berjalan dari area nodus hati melalui diafragma menuju ke nodi limfatisi mediastilis posterior.

Persarafan hati berasal dari saraf simpatis dan parasimpatis yang melewati koliakus. Trunkus vagus anterior mempunyai cabang yang banyak berjalan langsung ke hati.

\section{Saluran pada hati}

Saluran hati meliputi:

1. Duktus hepatikus dekstra dan sinistra, keluar dari hati pada porta hepatis bersatu membentuk duktus hepatikus komunis. Panjangnya kira-kira $4 \mathrm{~cm}$, berjalan turun pada tepi omentum minus. Tepi kanannya bersatu dengan duktus sistikus yang berasal dari kandung empedu untuk membentuk duktus koledukus.

2. Duktus koledukus, panjangnya sekitar $8 \mathrm{~cm}$. Bagian pertama berjalan dari tepi kanan omentum minus, di depan tepi kanan vena portae sebelah kanan arteri hepatika. Bagian kedua berjalan ke belakang bagian pertama duodenum, sebelah kanan $A$. Gastroduodenalis, bagian ketiga terletak dalam alur permukaan posterior kaput pankreas. Disini duktus koledukus bersatu dengan duktus pankreatikus mayor, bermuara pada ampula kecil dinding duodenum melalui suatu papila kecil yang disebut papila vateri.

Hati merupakan organ metabolik terbesar dan terpenting yang memiliki berbagai fungsi yang berhubungan dengan pencernaan untuk sekresi garam empedu yang melakukan berbagai fungsi.

\section{Fisiologi Hati}

Fungsi Hati Meliputi:

1. Fungsi metabolik: metabolisme asimilasi karbohidrat, lemak, protein, dan vitamin, serta produksi energi. Seluruh monosakarida akan diubah menjadi glukosa dan pengaturan glukosa dalam darah ini terjadi di hati. Pembentukan asam lemak dan lipid, pembentukan fosfolipid terjadi di hati. Metabolisme protein mengubah asam amino yang bersatu menjadi yang lain. Dan pembentukan albumin dan globulin juga terjadi hati.

2. Fungsi ekskretori : produksi empedu oleh sel hati (bilirubin, kolestrol, garam empedu). Ke dalam empedu juga di ekskresikan zat byang berasal dari luar tubuh seperti logam-logam berat atau bermacam zat warna.

3. Fungsi pertahanan tubuh: detoksikasi racun siap untuk dikeluarkan, melakukan fagositosis terhadap benda asing langsung membentuk antibodi. Bila hati rusak maka berbaga racun 
akan meracuni tubuh. Bermacam-macam cara mendetoksikasikan racun, misalnya pembentukan urea dari amoniak atau zat beracun dioksidasi/direduksi/dihidrolisis dengan zat-zat yang lain untuk mengurangi toksis dari racun tersebut.

4. Pengaturan dalam peredaran darah: berperan membentuk darah dan heparin dihati dan mengalirkan darah kejantung. Dalam hati sel darah merah akan rusak karena terdapt selsel sistem retikoloendotelium (RES). Perusakan ini juga terdapat dalam limpa dan sum-sum tulang.

5. Hati membentuk asam empedu terutama dari kolestrol yang membentuk pigmen-pigmen empedu terutama dari hasil perusakan hemoglobin.

6. Sintesis protein: mencakup protein-protein penting untuk pembekuan darah serta mengangkut hormon tiroid, steroid dan kolesterol

7. Detoksifikasi/degradasi: zat-zat sisa dan hormon serta obat dan senyawa asing lainnya. Selama 6 bulan kehidupan fetus, hepar memproduksi sel-sel darah merah, fungsi tersebut di ambil alih oleh sum-sum tulang. Sepanjang masa sel-sel darah merah dihancurkan dalam sel-sel sistem retikuloendotel termasuk yang melapisi sinusoid dari nhepar.

Sel-sel hati merupakan satu kompleks laboratorium kimia dengan sejumlah proses berbeda terjadi di dalamnya. Kebutuhan tubuh diberi sinyal oleh hormon dan enzim dan enzim yang mengatur metabolisme lemak. Di dalam hati asam lemak disintesis melalui proses lipogenesis membentuk trigliserida baru. Bahan ini kemudian keluar dari hati dengan bantuan liporotein yang membawanya ke jaringan adiposa untuk disimpan kecuali bila diperlukan.

Karbohidrat, seperti lemak, merupakan bahan untuk terjadinya proses lipogenesis. Asam lemak dan gliserol disintesis dari karbohidrat. Proses ini menyebabkan terjadinya kelebihan kalori yang berasal dari karbohidrat selain dari simpanan lemak yang telah ada.

Proses lipolisis juga terjadi dalam hati pada waktu yang sama seperti trigliserida untuk membentuk asam lemak dan gliserol. Reaksi trigliserida merupakan reaksi bolak balik yang terjadi akibat kebutuhan organisme pada waktu tertentu. Jika suplai lemak berlebihan dalam hati maka proses lipogenesis akan mengubah lemak tersebut menjadi bentuk yang dapat di transpor dan disimpan. Jika suatu organisme memerlukan energi yang berasal dari lemk, maka proses lipolisis akan terjadi. Trigliserida dapat dihidrolisis dan disintesis kembali untuk dipakai sebagai energi untuk membentuk lemak lain seperti fosfolipid dan kolesterol.

Di dalam hati, kolsterol disintesis dari 2 molekul karbon yang bersala daro asetil CoA. Hati juga mengeluarkan kolesterol dari sirkulasi. Kolesterol dari kedua sumber ini akan di ubah menjadi asam empedu yang akan masuk ke dalam kantong empedu untuk di simpan sebagai komponen empedu.

\section{KANDUNG EMPEDU}

Kandung empedu (vesika felea) adalah kantong yang berbentuk buah pir yang terletak pada permukaan viseral. Kandung empedu diliputi oleh peritonium kecuali bagian yang melekat pada hepar, terletak pada permukaan bawah hati diantara lobus dekstra dan lobus quadratus hati. 
Empedu terdiri dari:

1. fundus vesika felea : berbentuk bulat, biasanya menonjol di bawah tepi inferior hati, berhubungan dengan dinding anterior abdomen setinggi rawan ujung kosta IX kanan.

2. Korpus vesika felea: bersentuhan dengan permukaan viseral hati mengarah ke atas, ke belakang danke kiri

3. Kolum vesika felea : berlanjut dengan duktus sistikus yang berjalan dalam omentum minus bersatu dengan sisi kanan duktus hepatikus komunis membentuk duktus koledukus.

\section{Cairan Empedu}

Cairan empedu merupakan cairan yang kental berwarna kuning keemasan (kuning kehijauan) yang dihasilkan terus menerus oleh sel hepar lebih kurang 500-1000 ml sehari. Empedu merupakan zat esensial yang diperlukan dalam pencernaan dan penyerapan lemak:

Unsur-unsur Cairan Empedu:

1. Garam-garam empedu: disintesis oleh hepar dari kolesterol, suatu alkohol steroid yang banyak dihasilkan hati. Garam empedu berfungsi membantu pencernaan lemak, mengemulsi lemak dengan kelenjar lipase dari pankreas.

2. Sirkulasi enterohepatik: garam empedu (pigmen empedu) diresorpsi dari usus halus kedalam vena portae, dialirkan kembali ke hepar untuk digunakan ulang.

3. Pigmen-pigmen empedu: merupakan hasil utama dari pemecahan hemoglobin. Sel hepar mengangkut hemoglobin dari plasma dan menyekresinya ke dalam empedu. Pigmen empedu tidak mempunyai fungsi dalam proses pencernaan.

4. Bakteri dalam usus halus: mengubah bilirubin menjadi urobilin, merupakan salah satu zat yang diresorpsi dari usus, di ubah menjadi sterkobili yang disekresi ke dalam feses sehingga menyebabkan feses berwarna kuning.

\section{SALURAN EMPEDU}

Saluran empedu berkumpul menjadi duktus hepatikus kemudian bersatu dengan duktus sistikus, karena akan tersimpan dalam kandung empedu. Empedu mengalami pengentalan 510 kali, dikeluarkan dari kandung empedu oleh aksi koleksistokinin, suatu hormon yang dihasilkan dalam membran mukosa dari bagian atas usus halus tempat masuknya lemak. Kolesistokinin menyebabkan kontraksi otot kandung empedu. Pada waktu bersamaan terjadi relaksasi sehingga empedu mengalir ke dalam duktus sistikus dan duktus koledukus.

\section{FISIOLOGI EMPEDU}

Empedu adalah produk hati, merupakan cairan yang mengandung mukus, mempunyai warna kuning kehijauan dan mempunyai reaksi basa. Komposisi empedu adalah garam-garam empedu, pigmen empedu, kolesterol, lesitin, lemak dan garam organik. Pigmen empedu terdiri dari bilirubin dan biliverdin. Pada saat terjadinya kerusakan butiran-butiran darah merah, hemoglobin dikeluarkan dari butiran-butiran darah merah terurai menjadi globin dan bilirubin, sebagai pigmen yang tidak mempunyai unsur besi lagi.

Pembentukan bilirubin terjadi dalam sistem retikuloendotel di dalam sum-sum tulang, limpa dan hati. Bilirubin yang telah dibebaskan kedalam peredaran darah disebut kolebilirubin. Garam empedu dibentuk dalam hati, terdiri dari natrium glikokolat dan natrium taurokolat. Garam empedu ini akan menyebabkan kolesterol di dalam empedu dalam keadaan larutan. 
Garam-garam empedu tersebut mempunyai sifat hirotropik. Garam empedu meningkatkan kerja enzim-enzim yang berasal dari pankreas, yaitu amilase, tripsin dan lipase. Garam empedu meningkatkan penyerapan baik lemak netral maupun asam lemak. Empedu dihasilkan oleh hati dan disimpan dalam kandung empedu sebelum disekresi ke dalam usus.

Pada waktu terjadi pencernaan, otot lingkar kandung empedu dalam keadaan relaksasi. Bersamaan dengan itu tekanan dalam kantong empedu akan meningkat dan terjadi kontraksi pada kandung empedu sehingga cairan empedu mengalir dan masuk ke dalam duodenum. Rangsangan terhadap saraf simpatis mengakibatkan terjadinya kontraksi pada kandung empedu.

\section{PANKREAS}

\section{Struktur Pankreas}

Pankreas merupakan organ yang lunak, berjalan miring menyilang dinding posterior abdomen pada regio epigastrikum. Pankreas terletak dibelakang lambung, terbentang dari duodenum sampai kelimpa. Pankreas merupakan kelenjar eksokrin dan kelenjar endokrin. Kelenjar eksokrin menghasilkan sekret yang mengandung enzim yang dapat menghidrolisis protein, lemak dan karbohidrat. Sedangkan kelenjar endokrin menghasilkan hormon insulin dan glukagon yang memegang peranan penting pada metabolisme karbohidrat.

Pankreas terdiri dari:

1. Kaput pankreas: berbentuk seperti cakram, terletak pada bagian cekung duodenum, melus kekiri dibelakang arteri dan vena mesenterika superior, permukaan depan kaput pankreas berbatas dengan kolon transpersum dan jejunum. Permukaan belakang berbatas dengan v. Kava inferior, duktus koledukus dan vena renalis

2. Kolum pankreas: merupakan bagian yang mengecil dan menghubungkan kaput pankreas, bagian ini terletak didepan pangkal vena porta dan pangkal arteri mesenterika superior dari aorta.

3. Korpus pankreas: berjalan keatas dan kekiri menyilang garis tengah, pada potongan melintang, sedikit berbentuk segitiga.

4. Kauda pankreas: berjalan menuju ligamentum lienorenalis dan mengadakan hubungan dengan hilus limpa. Didepan kauda berbatasan dengan fleksura koli sinistra, di kiri dan belakang berbatas dengan ginjal dan glandula suprarenalis kiri.

Pembuluh darah Pembuluh darah nadi yang memperdarahi pankreas meliputi:

1. Arteri pankreatika duodenalis superior: berasal dari arteri. Gastroduodenalis yang memperdarahi pankreas dan duodenum serta beranastomosis dengan arteri pankreatika duodenalis inferior.

2. Arteri pankreatika duodenali: mengurus duodenum dan kaput pankreatika dan beranastomosis dengan arteri pangkratikaduodenalis superior.

3. Arteri pankreatika mayus dan kaudalis. Berasal dari arteri renalis, beranastomosis dengan arteri pankreatikoduodenalis.

Pembuluh darah balik hepar meliputi:

1. Vena pankreatikoduodenalis superior yang bermuara ke dalam vena portae

2. Vena pankreatikoduodenalis inferior bermuara ke dalam vena mesenterika inferior.

3. Vena pankreatika mayus dan vena pankreatika kaudalus bermuara ke dalam vena lienalis. 
Di seluruh pankreas tersebar massa sel-sel yang terdiri dari pulau-pulau yang berbeda-beda besarnya yang disebut pulau langerhans. Jumlah sel dalam pulau tersebut 200.000-1.500.000 yang menghasilkan sekresi interna (hormon insulin). Insulin memegang peranan penting dalam metabolisme gula. Apabila gula darah meningkat diperkirakan penderita mengidap penyakit deabetes melitus. Saluran keluar pankreas adalah duktus pankreatikus mayus (wirsunganus) dan duktus pankreatikus minus (sartorini). Duktus ini bermuara pada papila vateri yang terletak pada dinding duodenum bersama duktus koledukus.

\section{FISIOLOGI PANKREAS}

Komposisi cairan pankreas bergantung pada rangsangan yang diterima oleh sel-sel sekretoris pankreas. Cairan pankreas yang mengandung enzim dapat ditingkatkan produksinya melalui rangsangan saraf maupun rangsangan hormonal. Rangsangan nervus vagus meningkatkan konsentrasi enzim di dalam cairan pankreas diiringi dengan menurunnya jumlah butiran zimogen yang terdapat dalam sel-sel aciner dari pankreas.

Serabut saraf parasimpatis menginervasi sel-sel aciner dan berhubungan dengan sel-sel dari pulau langerhans. Serabut saraf simpatis akan berakhir pada pembuluh darah pankreas dan rangsangan terhadap saraf simpatis akan mengakibatkan mrningkatnya sekresi cairan pankreas. Pemasukan HCL ke dalam duodenum mengakibatkan terjadinya sekresi cairan pankreas. Sekresi ini oleh $\mathrm{HCL}$ masih berlangsung ketika semua saraf yang menginervasi pankreas di putuskan.

Saraf memegang peranan dalam sekresi cairan pankreas. Zat aktif yang diperoleh dari ekstrak duodenum di kenal dengan nama sekretin yang meningkatkan pelarut enzim yang terdapat di dalam cairan pankreas. Cairan pankreas di hasilkan sebagai respons terhadap sekretin yang mempunyai berat jenis yang rendah tetapi mempunyai $\mathrm{pH}$ yang lebih tinggi dibandingkan dengan cairan pankreas yang dihasilkan sebagai respons terhadap rangsangan saraf.

Cairan pankreas mempunyai $\mathrm{pH}$ ke arah basa $(\mathrm{pH} 8,4)$ disebabkan adanya $\mathrm{NaHCO}$ sebesar 0,3-0,6\% yang berfungsi menetralisir asam. Dalam 24 jam di sekresi sebanyak 500-2000cc dan mengandung 8 gram NaCL. Cairan pankreas mengandung 2 macam protein yaitu albumin dan globulin dan mengandung 3 macam enzim yaitu lipase, amilase, dan tripsin. Tripsin adalah enzim proteolitik yang bekerja dengan optimum pada media yang bersifat basa. Enzim ini akan menguraikan protein menjadi polipeptida, selanjutnya diurai menjadi asam amino.

Amilase akan menguraikan pati menjadi maltosa diubah menjadi 2 molekul glukosa oleh maltosa yang terdapat di dalam sukus enterikus. Lipase akan menguraikan lemak netral (trigliserida) menjadi digliserida, monogliserida, asam lemak bebas dan gliserol. pH optimum amilase adalah 7,0 dan lipase 8,0.

Dalam proses pencernaan lemak garam-garam empedu berperan secara khusus untuk mengaktifkan lipase. Efek khusus yang mempengaruhi lipase adalah kemampuan garamgaram empedu untuk membuat lemak yang di konsumsi berubah bentuk menjadi sebuah emulsi sehingga permukaan lemak menjadi lebih besar sehingga memudahkan bagi lipase untuk mencernanya. 
SISTEM PERKEMIHAN - Ginjal merupakan orgn terpenting dalam mempertahankan cairan tubuh secara baik. Berbagai fungsi ginjal untuk mempertahankan homeostatik dengan mengatur volume cairan, keseimbangan osmotik, asam basa, ekskresi sisa metabolisme, sistem pengaturan hormonal dan metabolisme. Ginjal terletak dalam rongga abdomen, retroperitoneal primer kiri dan kanan kolumna vertebralais dikelilingi oleh lemak dan jaringan ikat dibelakang peritonium.

Batas atas ginjal kiri setinggi iga ke-11, ginjal kanan setinggi iga ke 12, batas bawah ginjal kiri setinggi vertebra lumbalis ke-3. Tiap-tiap ginjal mempunyai panjang $11,25 \mathrm{~cm}$, lebar $5-7 \mathrm{~cm}$, tebal 2,5 cm. Ginjal kiri lebih panjang dari ginjal kanan, berat ginjal pada laki-laki dewasa 150170 gram, wanita dewasa 115-155 gram. Bentuk ginjal seperti kacang, sisi luarnya cembung dan di atas setiap ginjal terdapat sebuah kelenjar suprarenal.

\section{STRUKTUR GINJAL}

Ginjal ditutupi oleh kapsul tunika fibrosa yang kuat. Apabila kapsul dibuka terlihat permukaan dari ginjal licin dengan warna merah tua.

Ginjal terdiri dari:

a. Bagian dalam (internal) medula. Substansia medularis terdiri dari piramid renalis jumlahnya antara 8-16 buah yang mempunyai basis sepanjang ginjal sedangkan apeksnya menghadap ke sinus renalis

b. Bagian luar (korteks). Substansia kortekalis berwarna cokelat merah, kosistensi lunak dan bergranula.

\section{Pembungkus ginjal}

Ginjal dibungkus oleh suatu massa jaringaan lemak yang disebut kapsula adiposa. Bagian yang paling tebal terdapat pada tepi ginjal yang memanjang melalui hilus renalis. Ginjal dan kapsula adiposa tertutup boleh suatu lamina khusus dari fasia subserosa yang disebut fasia renalis yang terdapat di antara lapisan dalam dari fasia profunda dan stratum fasia subserosa internus

\section{Elektromikroskopis glomerulus}

Glomerulus berdiameter $200 \mu \mathrm{m}$, dibentuk oleh invaginasi suatu anyaman kapiler yang menempati kapsula bowmen, mempunyai dua lapisan seluler yang memisahkan darah dari dalam kapiler glomerulus dan filtrat dalam kapsula bowmen yaitu lapisan endotel kapiler dan lapisan epitel khusus yang terletak di atas kapiler glomerulus.

\section{Peredaran darah ginjal}

Ginjal mendapat darah dari arteri renalis merupakan cabang dari aorta abdominalis, sebelum masuk ke massa ginjal. Arteri renalis mempunyai cabang yang besar yaitu arteri renalis anterior dan yang kecil arteri renalis posterior. Cabang anterior memberikan darah untuk ginjal anterior dan ventral. Cabang posterior memberikan darah untuk ginjal posterior dan bagian dorsal. Diantara kedua cabang ini terdapat suatu garis (brudels line) yang terdapat disepanjang margo lateral dari ginjal. Pada garis ini tidak terdapat pembuluh darah sehingga kedua cabang ini akan menyebar sampai kebagian anterior dan posterior dari kolisis ke medula ginjal terletak diantara piramid disebut arteri interloburalis. 
Setelah sampai di daerah medula membelok 90 - melalui basis piramid disebut arteri Arquarta dimana akan bercabang menjadi arteri interloburalis yang berjalan tegak ke dalam konteks berakhir sebagai:

a. Vasa aferen glomerulus untuk 1-2 glomerulus

b. Pleksus kapiler sepanjang tubulus melingkar dalam korteks tanpa berhubungan dengan glomerulus

c. Pembuluh darah menembus kapsula bowman

Dari glomerulus pembuluh darah aferen selanjutnya terdapat suatu anyaman yang mengelilingi tubuli kontorti. Disamping itu ada cabang yang lurus menuju pelvis renalis memberikan darah untuk ansa henle dan duktus koligen yang dinamakan arteri rektal ( $\mathrm{A}$. Spuriae). Dari pembuluh rambut ini kemudian berkumpul dalam pembuluh kapiler vena bentuknya seperti bintang disebut vena stellata beralan ke vena interlumbalis. Pembuluh limfe mengikuti perjalanan A renalis menuju ke nodi limfatikus aorta lateral yang terdapat disekitar pangkal A renalis, dibentuk oleh pleksus yang berasal dari massa ginjal, kapsula fibrosa dan bermuara di nodus lateral aortika.

\section{Persarafan ginjal}

Ginjal mendapat persarafan dari pleksus renalis (vasomotor). Saraf ini berfungsi untuk mengatur jumlah darah yang masuk ke dalam ginjal, saraf ini berjalan bersamaan dengan pembuluh darah yang masuk ginjal. Di atas ginjal terdapat kelenjar suprarenalis, kelenjar ini merupakan kelenjar buntu yang menghasilkan dua macam hormon yaitu hormon adrenalin dan hormon kortison. Adrenal dihasilkan oleh medulla

Fungsi Ginjal:

a. Mengatur volume air (cairan dalam tubuh). Kelebihan air dalam tubuh akan diekskresikan oleh ginjal sebagai urine (kemih) yang encer dalam jumlah besar, kekurangan air (kelebihan keringat) menyebabkan urine yang diekskresi berkurang dan konsentrasinya lebih pekat sehingga susunan dan volume cairan tubuh dapat dipertahankan relatif normal.

b. Mengatur keseimbangan osmitik dan mempertahankan keseimbangan ion yang optimal dalam plasma (keseimbangan elektrolit). Bila terjadi pemasukan/pengeluaran yang abnormal ion-ion akibat pemasukan garam yang berlebihan/penyakit perdarahan (diare, muntah) ginjal akan meningkatkan ekskresi ion-ion yang penting (mis. $\mathrm{Na}, \mathrm{K}, \mathrm{Cl}, \mathrm{Ca}$ dan posfat).

c. Mengatur keseimbangan asam-basa cairan tubuh bergantung pada apa yang dimakan, campuran makanan menghasilkan urine yang bersifat agak asam, pH kurang dari 6 ini disebabkan hasil akhir metabolism protein. Apabila banyak makan sayur-sayuran, urine akan bersifat basa. pH urine bervariasi antara 4,8-8,2. Ginjal menyekresi urine sesuai dengan perubahan $\mathrm{pH}$ darah.

d. Ekskresi sisa hasil metabolism (ureum, asam urat, kreatinin) zat-zat toksik, obat-obatan, hasil metabolism hemoglobin dan bahan kimia asing (pestisida).

e. Fungsi hormonal dan metabolisme. Ginjal menyekresi hormon renin yang mempunyai peranan penting mengatur tekanan darah (sistem renin angiotensin aldesteron) membentuk eritripoiesis mempunyai peranan penting untuk memproses pembentukan sel darah merah (eritropoiesis). Di samping itu ginjal juga membentuk hormone dihidroksi kolekalsiferol (vitamin D aktif) yang diperlukan untuk absorsi ion kalsium di usus. 


\section{URETER}

Terdiri dari 2 saluran pipa, masing-masing bersambung dari ginjal ke kandung kemih (vesika urinaria), panjangnya $\pm 25-30 \mathrm{~cm}$, dengan penampang $\pm 0,5 \mathrm{~cm}$. Ureter sebagian terletak dalam rongga abdomen dan sebagian terletak dalam rongga pelvis.

Lapisan dinding abdomen terdiri dari:

a. Dinding luar jaringan ikat (jarinagn fibrosa)

b. Lapisan tengah lapisan otot polos

c. Lapisan sebelah dalam lapisan mukosa

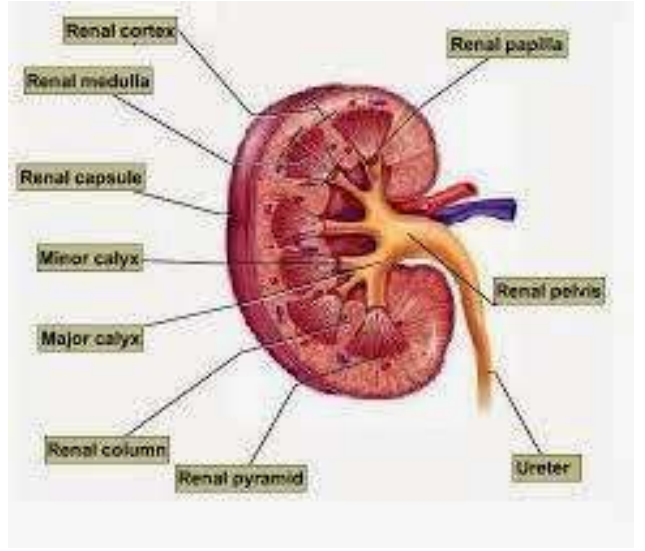

Lapisan didnding ureter menimbulkan gerakan-gerakan peristaltik tiap 5 menit sekali yang akan mendorong air kemih masuk ke dalam kandung kamih (vesika urinaria). Gerakan peristaltik mendorong urine melalui ureter yang diekskresikan oleh ginjal dan disemprotkan dalam bentuk pancaran, melalui osteum uretralis masuk ke dalam kandung kemih.

Ureter berjalan hampir vertikal ke bawah sepanjang fasia muskulus psoas dan dilapisi oleh peritoneum. Penyempitan ureter terjadi pada tempat ureter meninggalkan pelvis renalis, pembuluh darah, saraf dan pembuluh limfe berasal dari pembuluh sekitarnya mempunyai saraf sensorik.

Pembagian ureter menurut tempatnya

a. Pars abdominalis ureter dalam kavum abdomen ureter terletak di belakang peritoneum sebelah media anterior $\mathrm{m}$. psoas mayor dan ditutupi oleh fasia subserosa. Vasa spermatika/ovarika interna menyilang ureter secara oblique, selanjutnya ureter akan mencapai kavum pelvis dan menyilang arteri iliaka eksterna. Ureter kanan terletak pada pars desendens duodenum. Sewaktu turun ke bawah terdapat di kanan bawah dan disilang oleh kolon dekstra dan vosa iliaka iliokolika, dekat apertura pelvis akan dilewati oleh bagian bawah mesenterium dan bagian akhir ilium. Ureter kiri disilang oleh vasa koplika sinistra dekat apertura pelvis superior dan berjalan di belakang kolon sigmoid dan mesenterium.

b. Pars pelvis ureter berjalan pada bagian dinding lateral pada kavum pelvis sepanjang tepi anterior dari insura iskhiadikamayor dan tertutup olehperitoneum. Ureter dapt ditemukan di depan arteri hipogastrika bagian dalam nervus obturatoris arteri vasialia anterior dan arteri hemoroidalis media. Pada bagian bawah insura iskhiadika mayor, ureter agak miring ke bagian medial untuk mencapai sudut lateral dari vesika urinaria. 


\section{Ureter Pria dan Wanita}

Ureter pada pria terdapat di dalam visura seminalis atas dan disilang oleh duktus deferens dan dikelilingi oleh pleksus vesikalis. Selanjutnya ureter berjalan oblique sepanjang $2 \mathrm{~cm}$ di dalam dinding vesika urinaria pada sudut lateral dari trigonum vesika. Sewaktu menembus vesika urinaria, dinding atas dan dinding bawah ureter akan tertutup dan pada waktu vesika urinaria penuh akan membentuk katup (valvula) dan mencegah pengambilan urine dari vesika urinaria.

Ureter pada wanita terdapat di belakang fossa ovarika urinaria dan berjalan ke bagian medial dan ke depan bagian lateralis serviks uteri bagian atas, vagina untuk mencapai fundus vesika urinaria. Dalam perjalanannya, ureter didampingi oleh arteri uterina sepanjang $2,5 \mathrm{~cm}$ dan selanjutnya arteri ini menyilang ureter dan menuju ke atas di antara lapisan ligamentum. Ureter mempunyai $2 \mathrm{~cm}$ dari sisi serviks uteri. Ada tiga tempat yang penting dari ureter yang mudah terjadi penyumbatan yaitu pada sambungan ureter pelvis diameter $2 \mathrm{~mm}$, penyilangan vosa iliaka diameter $4 \mathrm{~mm}$ dan pada saat masuk ke vesika urinaria yang berdiameter $1-5 \mathrm{~cm}$.

\section{Pembuluh darah ureter}
a. Arteri renalis
b. Arteri spermatika interna
c. Arteri hipogastrika
d. Arteri vesika inferior

\section{Persarafan ureter}

Persarafan ureter merupakan cabang dari pleksus mesenterikus inferior, pleksus spermatikus, dan pleksu pelvis; seperti dari nervus; rantai eferens dan nervus vagusrantai eferen dari nervus torakalis ke-11 dan ke-12, nervus lumbalis ke- 1 , dan nervus vagus mempunyai rantai aferen untuk ureter.

\section{VESIKA URINARIA}

Vesika urinaria (kandung kemih) dapat mengembang dan mengempis seperti balon karet, terletak di belakang os pubis di dalam rongga panggul. Bentuk kandung kemih seperti kerucut yang dikelilingi oleh otot yang kuat, berhubungan dengan ligamentum vesika umbilikalis medius. Vesika urinaria pada waktu kosong terletak di apeks vesika ibelakang tepi atas simfisis pubis. Permukaan posterior berbentuk segitiga merupakan muara ureter dan sudut inferior membentuk uretra 


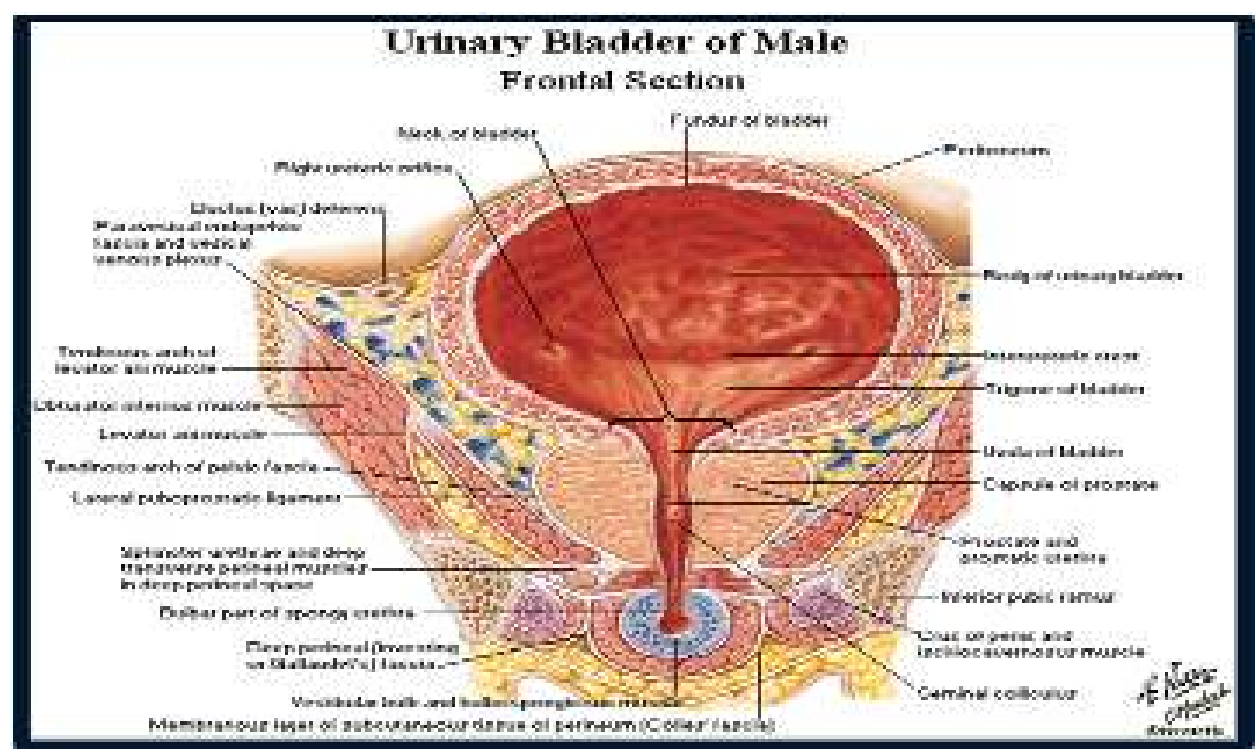

Bagian vesika urinaria terdiri dari:

a. Fundus yaitu, bagian yang menghadap ke arah belakang dan bawah, bagian ini terpisah dari rektum oleh spatium rectovesikale yang terisi oleh jaringan ikat duktus deferen, vesika seminalis dan prostat.

b. Korpus, yaitu bagian antara verteks dan fundus.

c. Verteks, bagian yang mancung ke arah muka dan berhubungan dengan ligamentum vesika umbilikalis.

Dinding kandung kemih terdiri dari lapisan sebelah luar (peritonium), tunika muskularis (lapisan otot), tunika submukosa, dan lapisan mukosa (lapisan bagian dalam). Pembuluh limfe vesika urinaria mengalirkan cairan limfe ke dalam nadi limfatik iliaka interna dan eksterna.

\section{Lapisan otot vesika urinaria}

Lapisan otot vesika urinaria terdiri dari otot polos yang tersusun dan saling berkaitan dan disebut $\mathrm{m}$. detrusor vesikae. Peredaran darah vesika urinaria berasal dari arteri vesikalis superior dan inferior yang merupakan cabang dari arteri iliaka interna. Venanya membentuk pleksus venosus vesikalis yang berhubungan dengan pleksus prostatikus yang mengalirkan darah ke vena iliaka interna.

\section{Persarafan vesika urinaria}

Persarafan vesika urinaria berasal dari pleksus hipogastrika inferior. Serabut ganglion simpatikus berasal dari ganglion lumbalis ke-1 dan ke-2 yang berjalan turun ke vesika urinaria melalui pleksus hipogastrikus. Serabut preganglion parasimpatis yang keluar dari nervus splenikus pelvis yang berasal dari nervus sakralis 2, 3 dan 4 berjalan melalui hipogastrikus inferior mencapai dinding vesika urinaria. 


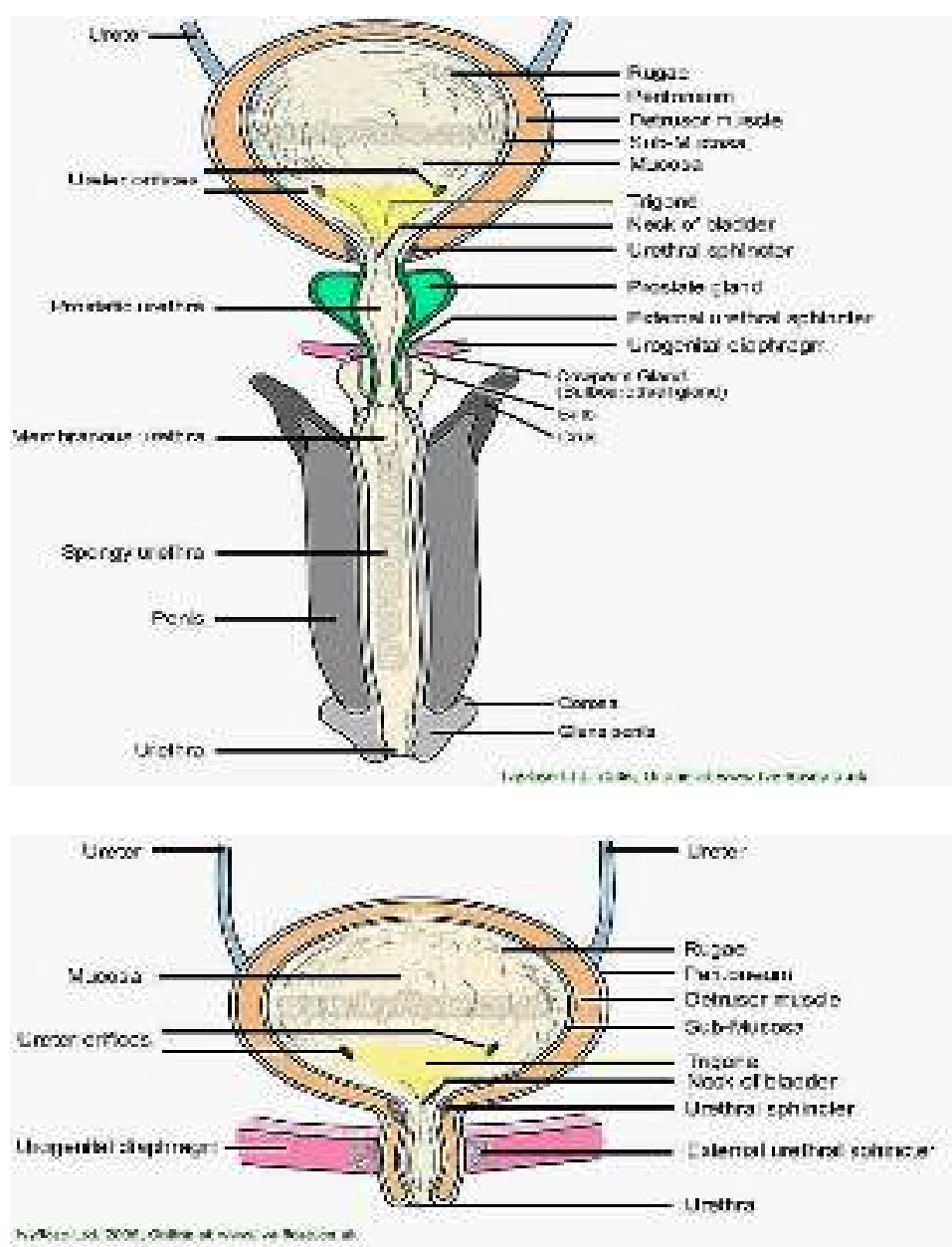

Sebagian besar serabut aferen sensoris yan g keluar dari vesika urinaria menuju sistem susunan saraf pusat melalui nervus splanikus pelvikus berjalan bersama saraf simpatis melalui pleksus hipogastrikus masuk kedalam segmen lumbal ke-1 dan ke-2 medula spinalis.

\section{Pengisian dan pengosongan vesika urinaria}

Dinding ureter mengandung otot polos yang tersusun dalam berkas spiral longitudinal dan sirkuler. Kontraksi peristaltik teratur 1-5 kali/menit menggerakkan urine dari pelvis renalis ke vesika urinaria disemprotkan setiap gelombang peritaltik. Ureter berjalan miring melalui dinding vesika urinaria untuk menjaga ureter tertutup kecuali selama gelombang peristaltik dan mencegah urine tidak kembali ke ureter. Kontraksi otot $\mathrm{M}$. detrusor bertanggungjawab untuk pengosongan vesika urinaria selama berkemih (mikturisi). Berkas otot berjalan pada sisi uretra. Serabut ini dinamakan sfingter uretra interna. Sepanjang uretra terdapat sfingter uretra membranosa (sfingter uretra eksterna).

\section{Berkemih}

Berkemih (Mikturisi) adalah peristiwa pembentukan urine. Karena dibuat di dalam, urine mengalir melalaui ureter ke kandung kencing. Keinginan membuang air kecil disebabkan penambahan tekanan di dalam kandung kencing, dan tekanan ini di sebabkan isi urine di dalamnya. Hal ini terjadi bila tertimbun 170 sampai $230 \mathrm{ml}$. mikturisi adalah gerak reflek yang dapat dikendalikan dan ditahan oleh pusat-pusat persarafan yang lebih tinggi pada manusia. 
Gerakannya ditimbulkan kontraksi otot abdominal yang menambah tekanan di dalam rongga abdomen, dan berbagai organ yang menekan kandung kencing membantu mengkosongkannya. Kandung kencing dikendalikan saraf pelvis dan serabut saraf simpatis dari pleksus hipogastrik.

\section{FILTRASI GLOMERULUS}

Kapiler glomerulus secara relatif bersifat impermeabel terhadap protein plasma yang lebih besar dan permeabel terhadap air dan larutan yang lebih kecil seperti alektrolit, asam amino, glukosa, dan sisa notrogen. Glomerulus mengalami kenaikan tekanan darah $90 \mathrm{mmHg}$. Kenaikan ini terjadi karena arteriola aferen yang mengarah ke glomerulus mempunyai diameter yang lebih besar dan memberikan sedikit tahanan dari kapiler yang lain. Tekanan darah terhadap dinding pembuluh ini di sebut tekanan hidrostatik (TH). Gerakan masuknya ke dalam kapsula bowman disebut sebagai filtrasi glomerulus. Tiga faktor dalam proses filtrasi dalam kapsula bowman menggambarkan integrasi ketiga faktor tersebut, yaitu:

1. Tekanan osmotik (TO): tekanan yang dikeluarkan oleh air (sebagai pelarut) pada membran semi permeabel sebagai usaha untuk menembus membran semipermeabel ke dalam area yang mengandung lebih banyak molekul yang dapat melewati membran semipermeabel. Pori-pori dalam kapiler glomerulus membuat membran semipermeabel mungkin untuk melewati membran semipermeabel mungkin untuk melewati yang lebih kecil dan air tetapi mencegah molekul yang lebih besar, misalnya protein dan plasma.

2. Tekanan hidrostatik (TH) : sekitar $15 \mathrm{mmHg}$ di hasilkan oleh adanya filtrasi dalam kapsula dan berlawanan dengan tekanan hidrostatik darah. Filtrasi juga mengeluarkan tekanan osmotik 1-3mmHg yang berlawanan dengan osmotik darah.

3. Perbedaan tekanan osmotik plasma dengan cairan dalam kapsula bowman mencerminkan perbedaan konsentrasi protein. Perbedaan ini menimbulkan pori-pori kapiler mencegah protein plasma untuk difiltrasi.

Tekanan hidrostatik plasma dan tekanan osmotik filtrat kapsula bouman bekerjasama untuk meningkatkan gerakan air. Molekul permeabel kecil dari plasma masuk ke dalam kapsula bowman. Tekanan hidostatik dan tekanan osmotik filtrat dalam kapsula Bouman masuk ke kapiler. Jumlah tekanan (90-3) - (32-15) $=70 \mathrm{mmHg}$, akan mempermudah pemindahan filtrat dari aliran darah ke dalam kapsula bowman. Laju ini dinamakan laju filtrasi glomerulus (LFG).

Pada orang sehat jumlah pertukaran filtrasi permenit $125 \mathrm{ml}$. Faktor klinis yang mempengaruhi LFG adalah tekanan hidrostatik dan tekanan osmotik filtrat. Hipoproteinemia terjadi pada kelaparan akan menurunkan tekanan osmotik dan meningkatkan LFG.

\section{PENGARUH HORMON}

Ginjal menyekresi hormon renin yang mempunyai peranan penting mengatur tekanan darah (sistem renin-angiotensin-aldosteron), membentuk eritropoiesis untuk memproses pembentukan sel darah merah (eritropoiesis). Disamping itu ginjal juga membentuk hormon dihiroksikolekalsiferol (vitamin D aktif) yang diperlukan untuk absorbsi ion kalsium di usus.

Pengaturan final urine di atur oleh 3 jenis hormon. Osmoreseptor pada hipotalamus sangat sensitif terhadap osmolaritas serum. Selama dehidrasi osmolaritas serum meningkat. Osmoreseptor pada hipotalamus merangsang sekresi, meningkatkan permeabilitas sel tubulus koligentes terhadap air ADH. 
Oleh karena penting untuk mempertahankan suatu keseimbangan yang tepat antara rearbsorbsi tubulus dan filtrasi glomerulus, mekanisme saraf, pengaturan filtrasi glomerulus. Rearbsorbsi dari beberapa zat terlarut dapat di atur secara bebas terpisah dari yang lain terutama melalui mekanisme pengontrolan hormonal.

\section{HORMON ANTI-DIURETIK}

Hormon antidiuretik (ADH) meningkatkan permeabilitas sel tubulus kolegentes terhadap air, memungkinkan resorpsi air sehingga cairan ekstraseluler (CES) kembali normal. Hormon lain yang mempengaruhi konsentrasi urine adalah renin. Bila laju filtrasi glomerulus (LFG) turun karena dehidrasi atau kehilangan darah, kadar natrium di bawah normal pada filtrasi, yang merangsang sekresi renin. Renin mengubah angiotensin yang di sekresi hati menjadi angiotensin 1 ,

Sel kapiler paru selanjutnya mengubah angiotensin I menjadi angiotensi II. Angotensin II mengonsentrasi otot polos sekeliling arteriola. Hal ini meningkatkan tekanan darah, selanjutnya meningkatkan laju filtrasi glomerulus (LFG). Angiotensin II juga mendorong sekresi aldosteron, hormon ketiga yang mempengaruhi osmolaritas urine.

Korteks adrenal jika dirangsang oleh angiotensin II menyekresi aldosteron dengan meningkatkan resorpsi air di ginjal, meningkatkan tekanan darah dan menurunkan osmolitas serum. Aldosteron juga berespons terhadap kadar abnormal natrium darah.

\section{HORMON ALDOSTERON}

Hormon aldosteron dihasilkan oleh korteks adrenal. Hormon ini mengeluarkan efek dalam sekresi natrium oleh ginjal. Saat sekresi aldosteron meningkatkan aktifitas pompa natrium menyebabkan natrium diserap dari urine yang dibentuk dalam tubulus distal ke dalam aliran darah.

Sekresi aldosteron dirangsang oleh turunnya konsentrasi natrium darah. Perubahan ini dideteksi oleh reseptor dalam ginjal (aparatus juksta glomerulus) yang melepaskan substansi renin dalam darah, diubah menjadi angiotensin. Angiotensin bekerja pada korteks adrenal. Pada saat pasien mengkonsumsi diet bebas natrium, urinenya tidak mengandung natrium. Kehilangan natrium dapat terjadi bila berkeringat banyak karena aktivitas fisik, dalam kondisi panas, saat muntah dan diare.

Penurunan konsentrasi natrium cairan ekstraseluler akan merangsang aldosteron secara langsung dari korteks adrenal, menyebabkan penurunan natrium tubular. Hal ini merangsang sekresi renin dari juksta glomerulus, secara tidak langsung merangsang resorpsi natrium dari sel-sel tubulus distal.

Ginjal juga berfungsi dalam homeostasis kadar kalium plasma. Bila terjadi peningkatan kalium dan kadar natrium normal, tubulus distal dan tubulus kolegentes dengan aktif menyekresi kalium kembali ke dalam urine. Terdapat mekanisme reabsorbsi khusus untuk ion divalen seperti kalsium, magnesium dan fosfat, serta mengatur konsentrasi plasma dari ion-ion. 
Mekanisme umpan balik yang mengendalikan sekresi vasopresin dan cara vasopresin dirangsang dengan peningkatan dan dihambat oleh penurunan dalam tekanan osmotik. Diuresis air yang ditimbulkan oleh minum banyak cairan hipotonik di mulai sekitar 15 menit setelah minum. Beban air mencapai maksimum sekitar 40 menit. Kerja minimum menimbulkan penurunan kecil dalam sekresi vasopresin sebelum air diabsorbsi. Hambatan yang timbul karena penurunan osmolitas plasma setelah air diabsorbsi. Sementara menyekresi, beban osmotik rata-rata aliran urine maksimum yang dapat ditimbulkan setelah air diabsorbsi. Sementara menyekresi, beban osmotik rata-rata aliran urine maksimum yang dapat ditimbulkan selama diuresiselama diuresis akut sekitar 16 $\mathrm{ml} /$ menit. Jika air minum pada kecepatan lebih tinggi untuk waktu tertentu maka terjadi pembengkakan s akut sekitar $16 \mathrm{ml} /$ menit. Jika air minum pada kecepatan lebih tinggi untuk waktu tertentu maka terjadi pembengkakan sel karena ambilan air dari CES hipotonik menjadi parah, gejala keracunan air timbul karena pembengkakan sel (edema).

\section{REABSORBSI DAN SEKRESI TUBULUS}

Kurang $80 \%$ filtrat dikembalikan ke aliran darah melalui reabsorbsi pada tubulus proksimal. Pada orang normal, semua glukosa, asam amino, natrium klorida dan elektrolit difiltrasi dan diabsorbsi di sini. Sei-sel tubulus proksimal juga menyekresi urea, kreatinin, hidrogen dan amonia bercampur dengan urine.

Pada ans Henle, filtrat urine menjadi lebih tinggi konsentrasinya. Bagian pars asensen berdinding tipis, cukup permeabel bersama dengan cairan intertisial yang berkonsentrasi tinggi menyebabkan air berosmosis dari filtrat ke dalam cairan intertisial dalam membuat filtrat cukup pekat sampai waktunya filtrat mencapai ansa pars asenden.

Pars asenden berdinding tebal, secara relatif impermeabel terhadap air. Pars ini mengandung ion karier, secara aktif mentranspor natrium keluar dari filtrat. Pengeluaran elektrolit tanpa air membuat filtrat lebih encer dari sebelumnya. Pada tubulus distal natrium kembali di reabsorbsi melalui transpor aktif hirogen dan kalium, serta asam urat dapat di tambahkan ke dalam urine melalui sekresi tubular. Duktus kolegentes (tubulus kolegentes) menerima isi dari banyak tubulus distalis dan tidak direabsorsi atau sekresi elektrolit. Pada orang yang hidrasinya baik reabsorbsi air juga tidak ada.

Sewaktu filtrat glomerulus memasuki tubulus ginjal, filtrat ini mengalir melalui bagianbagian tubulus. Sebelum dieksresikan sebagai urine, beberapa zat diabsorbsi kembali secara selektif dari tubulus dan kembali kedalam darah. Sedangkan yang lain disekresikan dari darah kedalam urine akan menggambarkan penjumlahan dari tiga proses dasar ginjal (filtrasi glomerulus, reabsorbsi tubulus, dan sekresi tubulus). Eksrkresi urine adalah hasil filtrasi glomerulus di kurangi reabsorbsi tubulus dan di tambah sekresi tubulus.

\section{REABSORSI TUBULUS}

Ginjal menangani beberapa zat yang difiltrasi secara bebas dalam ginjal dan diabsorbsi dengan kecepatan yang berbeda. Kecepatan masing-masing zat yang difiltrasi dapat dihitung dengan rumus:

Filtrasi = kecepatan filtrasi glomerulus $\mathrm{x}$ kecepatan plasma 
Perhitungan ini menganggap bahwa zat-zat difiltrasi secara bebas dan tidak terikat pada protein plasma. Kebanyakan zat proses filtrasi glomerulus dan reabsorbsi tubulus secara kuantitatif relatif sangat besar terhadap sekresi urine. Sedikit saja perubahan pada filtrasi glomerulus atau reabsorbsi tubulus. Secara potensial dapat menyebabkan perubahan yang relatif besar. Beberapa produk buangan seperti ureum dan kreatinin sulit diabsorbsi dari tubulus dan dieksresi dalam jumlah yang relatif besar.

\section{MEKANISME PASIF}

Zat yang akan diabsosorbsi harus ditranspor melintasi membran epitel tubulus ke dalam cairan intertisial ginjal, melalui kapiler peritubulus kembali ke dalam darah. Reabsorbsi melalui epitel tubulus ke dalam darah, misalnya air dan zat terlarut dapat ditranspor melalui membran selnya sendiri (jalur transeluler) atau melalui ruang sambungan antara sel (jalur paraseluler).setelah diabsorbsi melalui sel epitel tubulus ke dalam cairan intertisial, air dan zat terlarut ditranspor melalui dinding kapiler ke dalam darah dengan cara ultrafiltrasi yang diperantarai oleh tekanan hidrostatik dan tekanan osmotik koloid.

\section{TRANSPOR AKTIF}

Transpor pasif mendorong suatu zat terlarut melawan gradien elektrokimia dan membutuhkan energi yang berasal dari metabolisme. Transpor yang berhubungan langsung dengan suatu sumber energi seperti hidrolisis adenosin trifosfat (ATP) di sebut transpor aktif primer. Transpor yang tidak berhubungan secara langsung dengan suatu sumber energi seperti yang diakibatkan oleh gradien ion disebut transpor aktif sekunder.

\section{REABSORBSI TUBULUS PROKSIMAL}

Secara normal sekitar $65 \%$ dari muatan natrium dan air yang difiltrasi dan nilai persentase terendah dari klorida akan diabsorbsi oleh tubulus proksimal sebelum filtrat mencapai ansa Henle. Persentase ini dapat meningkat atau menurun dalam berbagai kondisi fisiologis.

Sel tubulus proksimal mempunyai banyak sekali brush border, permukaan membran epitel brush border di muati molekul protein yang mentranspor ion natrium melewati membran lumen yang bertalian dengan mekanisme transpor nutrien organik (asam amino dan glukosa). Tubulus proksimal merupakan tempat penting untuk sekresi asam dan basa organik seperti garam empedu, oksalat, urat, dan katekolamin.

REMIFIKASI POTENSIAL GAGAL GINJAL

\begin{tabular}{|c|c|}
\hline FAKTOR REMIFIKASI & URAIAN \\
\hline Toksisitas uremik & $\begin{array}{l}\text { Disebabkan oleh retensi zat-zat sisa mual, muntah, diare, dan } \\
\text { ulkus akibat efek toksik pada sistem pencernaan. Kecenderungan } \\
\text { mengalami perdarahan akibat efek toksik pada fungsi trombosit. } \\
\text { Perubahan mental. Misalnya penurunan kewaspadaan, insomnia } \\
\text { dan gangguan pemusatan perhatian, yang berkembang menjadi } \\
\text { serangan kejang dan koma akibat efek toksik pada susunan saraf } \\
\text { pusat. Kelainan aktifitas sensorik dan motorik akibat efek toksik } \\
\text { pada saraf perifer. }\end{array}$ \\
\hline
\end{tabular}




\begin{tabular}{|c|c|}
\hline Asidosis metabolik & $\begin{array}{l}\text { Disebabkan oleh ketidakmampuan ginjal secara adekuat } \\
\text { menyekresi } \mathrm{H}+\text { yang terus menerus ditambahkan ke cairan tubuh } \\
\text { sebagai hasil aktivitas metabolisme. }\end{array}$ \\
\hline Retensi kalium & $\begin{array}{l}\text { Diakibatkan sekresi inadekuat } \mathrm{K}+\text { olej tubulus. Gangguan } \\
\text { eksitabilitas jantung dan saraf sebagai akibat perubahan } \\
\text { potensial membran istirahat sel-sel yang eksitabilitas } \\
\text { (menghasilkan sinyal listrik jaringan saraf dan otot) }\end{array}$ \\
\hline $\begin{array}{l}\text { Ketidakseimbangan } \\
\text { natrium }\end{array}$ & $\begin{array}{l}\text { Disebabkan ketidakmampuan ginjal menyesuaikan ekskresi } \mathrm{Na}+ \\
\text { untuk mengimbangi perubahan konsumsi } \mathrm{Na}+\text {. Peningkatan } \\
\text { tekanan darah, edema generalisata, dan ginjal jantung kongestif } \\
\text { apabila konsumsi } \mathrm{Na}+\text { terlalu banyak. Hipotensi dan apabila } \\
\text { cukup parah, syok sirkulasi apabila konsumsi } \mathrm{Na}+\text { terlalu sedikit }\end{array}$ \\
\hline $\begin{array}{l}\text { Ketidakseimbangan } \\
\text { fosfat dan kalsium }\end{array}$ & $\begin{array}{l}\text { Disebabkan oleh gangguan rebsotrbsi elektrolit gangguan } \\
\text { struktur rangka akibat kelainan pengendapan kristal kalsium } \\
\text { fosfat yang memperkeras tulang }\end{array}$ \\
\hline $\begin{array}{l}\text { Hilangnya protein } \\
\text { plasma }\end{array}$ & $\begin{array}{l}\text { Akibat peningkatan kebocoran membran glomerulus, edema } \\
\text { yang disebabkan oleh penurunan tekanan osmotik koloid } \\
\text { plasma. }\end{array}$ \\
\hline $\begin{array}{l}\text { Ketidakmampuan } \\
\text { mengubah-ubah } \\
\text { konsentrasi urine }\end{array}$ & $\begin{array}{l}\text { Akibat gangguan countercurent. Hipotonisitas cairan tubuh } \\
\text { apabila ingesti } \mathrm{H} 2 \mathrm{O} \text { terlalu banyak. Hipertonisitas cairan tubuh } \\
\text { apabila ingesti } \mathrm{H} 2 \mathrm{O} \text { terlalu sedikit }\end{array}$ \\
\hline Hipertensi & $\begin{array}{l}\text { Disebabkan oleh efek kombinasi retensi garam dan cairan serta } \\
\text { efek vasokonstriksi kelebihan angiotensin II }\end{array}$ \\
\hline Anemia & Akibat dari gangguan produksi eritropoietin \\
\hline $\begin{array}{l}\text { Penekanan sistem } \\
\text { imun }\end{array}$ & $\begin{array}{l}\text { Kemungkinan besar disebabkan oleh kadar toksik zat-zat sisa, } \\
\text { peningkatan konsentrasi asam dan kerentanan terhadap infeksi. }\end{array}$ \\
\hline
\end{tabular}


Sistem Respirasi adalah suatu peristiwa ketika tubuh kekurangan oksigen (O2) dan $\mathrm{O} 2$ yang berada diluar tubuh dihirup (inspirasi) melalui organ pernpasan. Pada keadaan tertentu tubuh kelebihan karbon dioksida (CO2), maka tubuh berusaha untuk mengeluarkan kelebihan tersebut dengan menghembuskan napas (ekspirasi) sehingga terjadi suatu keseimbangan antara $\mathrm{O} 2$ dan $\mathrm{CO} 2$ di dalam tubuh

Fungsi pernapasan

1. Mengambil $\mathrm{O} 2$ dari luar masuk kedalam tubuh, beredar dalam darah. Selanjutnya terjadi proses pembakaran dalam sel atau jaringan

2. Mengeluarkan $\mathrm{CO} 2$ yang terjadi dari sisa-sisa hasil pembakaran dibawa oleh darah yang berasal dari sel (jaringan). Selanjutnya dikeluarkan melalui organ pernapasan

3. Untuk melindungi sistem permukaan dari kekurangan cairan dan mengubah suhu tubuh

4. Melindungi sistem pernapasan dari jaringan lain terhadap serangan patogenik

5. Untuk pembentukan komunikasi seperti berbicara, bernyanyi, berteriak dan menghasilkan suara

\section{Anatomi Sistem Pernapasan}

Anatomi saluran pernapasan terdiri atas saluran pernapasan atas (hidung, sinus paranasal, dan faring), saluran pernapasan bagian bawah (laring, trachea, bronchus, dan alveoli), sirkulasi pulmonal (ventrikel kanan, arteri pulmonal, arteriola pulmonal, kapiler pulmonal, venula pulmonal, vena pulmonal, dan atrium kiri), paru-paru (paru-paru kanan 3 lobus dan paru-paru kiri 2 lobus), rongga perut, dan otot-otot pernapasan.

a. Rongga Hidung

Bentuk dan struktur hidung menyerupai piramid atau kerucut dengan alasnya pada prosesus palatinus osis maksilaris dan pars horizontal osis palatum.

Rongga hidung dilapisi dengan epitelium silinder dan sel spitel berambut yang mengandung sel cangkir atau sel lendir sehingga permukaan nares basah dan berlendir. Selaput lendir ini kaya akan pembuluh darah, yang bersambung dengan lapisan farinx dan dengan semua sinus yang mempunyai lubang masuk dalam rongga hidung

Hidung menghubungkan lubang-lubang sinus udara para nasalis yang masuk kedalam rongga hidung dan lubang naso-lakrimal yang menyalurkan air mata (bawah rongga nasalis).

Fungsi hidung antara lain:

a. Menghangatkan udara. Udara dihangatkan oleh permukaan konka dan septum nasalis setelah melewati faring dengan suhu kurang lebih $36^{\circ} \mathrm{C}$.

b. Melembabkan udara. Sejumlah besar udara dilembabkan sebelum melewati hidung dan bila mencapai faring kelembaban kurang lebih $75 \%$.

c. Menyaring udara yang masuk. Udara yang disaring oleh bulu-bulu hidung jauh lebih banyak dan partikel diatas rongga disaring oleh rambut vestibular, lapisan mukosilier dan lisozim.

d. Penciuman. Pada pernapasan, biasa 5-10\% udara pernapasan melalui celah olfaktori 


\section{Struktur Hidung}

Tulang rawan epitelium dan lamina propia yang saling berkaitan. Lamina propia mengandung banyak arteri, vena, dan kapiler yang membawa nutrisi dan air yang dikeluarkan sel. Rangka hidung dibentuk oleh:

- Bagian atas oleh lamina kribosa ossis etmoidalis dan pars nasalis ossis frontalis

- Dinding lateral oleh tulang keras dan tulang rawan

- Sekat hidung (septum nasi) oleh tulang karang dan tulang rawan

Kavum nasi terdiri dari:

- Prosessus spenoetmoidalis terletak antara konka suprima dan konka superior

- Meatus nasi superior antara konka superior dan konka media

- Meatus nasi media antara konka media dan konka inferior

Sinus Paranasal

Sinus paranasal berperan dalam menyekresi mucus, membantu pengaliran air mata melalui saluran nasolakrimalis, dan membantu dalam menjaga permukaan rongga hidung tetap bersih dan lembap. Sinus paranasal juga termasuk dalam wilayah pembau di bagian posterior rongga hidung. Wilayah pembau tersebut terdiri atas permukaan inferior palatum kribriform, bagian superior septum nasal, dan bagian superior konka hidung. Reseptor di dalam epitel pembau ini akan merasakan sensasi bau.

Bagian bagian dari hidung:

- Batang hidung: dinding depan hidung yang dibentuk oleh ossa nasalis

- Cuping hidung: bagian bawah dinding lateral hidung yang dibentuk oleh tulang rawan

- Septum nasi: dinding yang membatasi dua rongga hidung

- Dinding lateral rongga hidung (kavum nasi)

Pembuluh darah hidung:

- Arteri palatina, bercabang dua yaitu arteri nasalis posterior lateralis dan arteri nasalis posterior septi

- Arteri nasalis anterior, berasal dari arteri oftalmika, mempunyai cabang arteriores lateralis dan arteri nasalis anteriores septi

- Vena hidung: terdapat kribosa jaringan pada daerah konka.

Perdarahan hidung (kavum nasi) disebabkan oleh pecahnya pembuluih darah vena dihidung yang disebut epitaksis

Refleks batuk; batuk merupakan cara paru mempertahankan diri bebas dari benda asing. Bronkus dan trakea begitu sensitif sehingga setiap benda asing atau penyebab iritasi lain merangsang refleks batuk. 


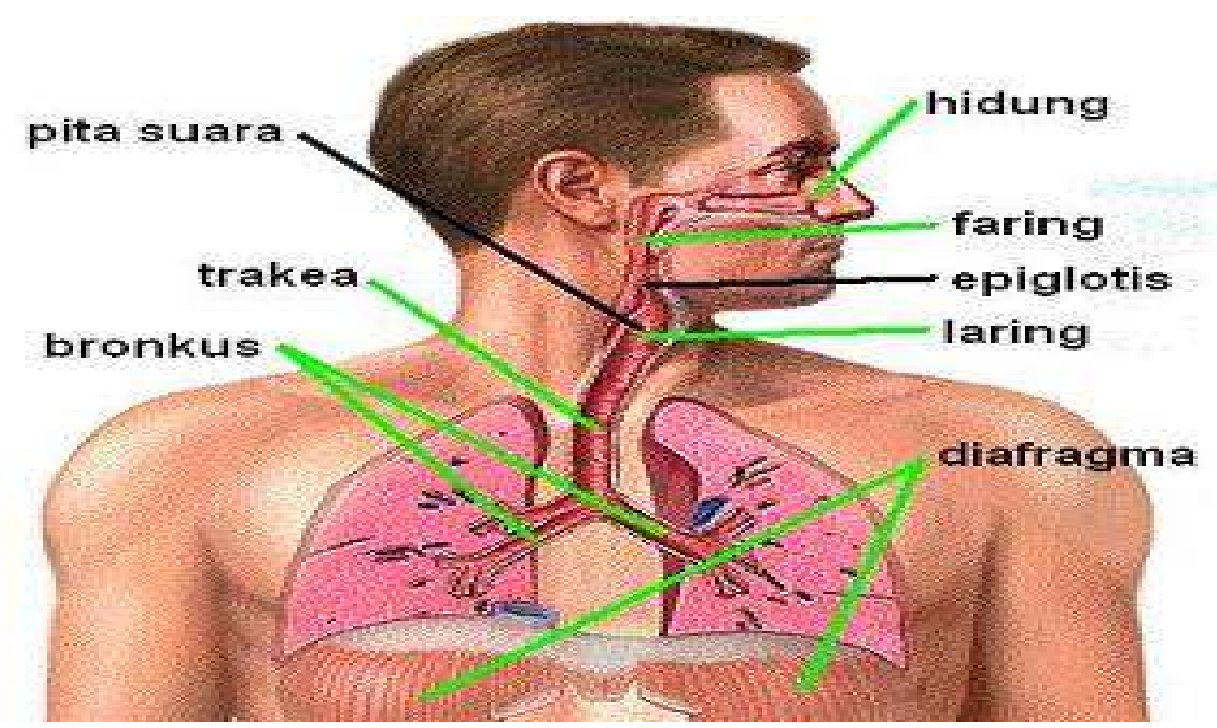

b. Faring

Faring merupakan tempat persimpangan antara jalan pernafasan dan jalan makanan. Faring merupakan bagian belakang dari rongga hidung dan rongga mulut.

Faring dibagi menjadi 3 bagian yaitu:

1) Nasofaring

Nasofaring merupakan bagian utama dari faring. Disamping sebagai saluran udara, nasofaring juga mempunyai peran sebagai penangkal infeksi dan penunjang fungsi telinga. Bagian lateral dinding nasofaring terdapat dua lubang yaitu osteum faring dan lobang medial (tuba faringeotimpanika)

2) Orofaring

Orofaring merupakan bagian tengah dari faring yang terletak dibelakang rongga mulut dan berperan sebagai saluran udara serta saluran makanan. Mempunyai dua hubungan yaitu:

- Ventral dengan kavum oris, melalui batas istmus fausium

- Kaudal terhadap radiks lingua, terdapat lubang yang merupakan batas antara laring dan faring, terdapat suatu lipatan dalam faring dan efiglotis yang merupakan batas antara oral dsan faring

3) Laringofaring

Laringofaring merupakan bagian terakhir dari faring. Seperti orofaring, bagian ini berperan sebagai saluran udara dan saluran makanan. Fungsi faring: lipatan lipatan vokal suara mempunyai elastisitas yang tinggi dan dapat memproduksi suara yang dihasilkan oleh pita suara

c. Laring

Laring (pangkal tenggorokan) merupakan saluran udara dan bertindak sebagai pembentukan udara, bagian pertama dari saluran pernapasan bagian bawah. Laring terletak di antara faring dan trachea. Berdasarkan letak vertebra servikalis, laring berada di ruas ke-4 atau ke-5 dan berakhir di vertebra servikalis ruas ke-6. Laring disusun oleh 9 kartilago yang disatukan oleh ligamen dan otot rangka pada tulang hiouid di bagian atas dan trachea di bawahnya. 
Kartilago yang terbesar adalah kartilago tiroidea, dan di depannya terdapat benjolan subkutaneus yang dikenal sebagai jakun yang terlihat nyata pada pria. Kartilago tiroidea dibangun oleh dua lempeng besar yang bersatu di bagian anterior membentuk sebuah sudut seperti huruf $\mathrm{V}$ yang disebut tonjolan laringeal.

Kartilago krikoidea adalah kartilago berbentuk cincin yang terletak di bawah kartilago tiroidea (ini adalah satu-satunya kartilago yang berbentuk lingkaran lengkap). Kartilago aritenoidea adalah sepasang kartilago yang menjulang di belakang krikoidea, dan di atasnya terdapat kartilago kuneiform dan kurnikulata yang sangat kecil. Di atas kartilago tiroidea terdapat epiglottis yang berupa katup dan berfungsi membantu menutup laring saat menelan makanan.

Laring dilapisi oleh selaput lendir, kecuali pita suara dan bagian epiglotis yang dilapisi oleh sel epitelium berlapis. Pita suara ini berjumlah dua: bagian atas adalah pita suara palsu dan tidak mengeluarkan suara yang disebut dengan ventrikularis, bagian bawah adalah pita suara yang sejati yang membentuk suara disebut dengan vokalis.

Pada laring terdapat artikulasio (persendian)

- Artikulasio krikoitiroidea: suatu sumbu hampir tegak lurus pada fasis artikularis terletak dalam bidang frontal

- Artikulasio krikoariteniodea: pergerakan artikulasio ini ke medioventrokaudal dan laterodorsokranial, pergerakan menggeser dengan jurusan yang sama

Laring mempunyai peran utama yaitu sebagai saluran udara, sebagai pintu pengatur perjalanan udara pernafasan dan makanan (switching mechanism) serta sebagian organ penimbul suara. Peran sebagai pengatur perjalanan udara pernafasan dan makanan dilakukan oleh epiglotis sedangkan peran sebagai organ penimbul suara dilakukan oleh pita suara (korda vokalis).

Teori fibrasi pita suara:

- Aerodinamik: fibrasi pita suara palsu bergantung pada tinggi tekanan udara subglotik

- Neuromuskuler: variasi pita suara sebagai akibat kontraksi otot intrinsik meskipun tidak mungkin

Gangguan bicara meliputi:

- Disfasia: kesukaran untuk mengerti suatu pembicaraan atau berbicara, terjadi karena kerusakan hemisfer serebri, tumor

- Disartria: kerusakan artikulasi atau mengucapkan kata dengan tidak benar, karena kelainan kontrol neuromuskuler dari otot artikulasi

- Dislalia: artikulasi abnormal yang disebabkan oleh kelainan lidah, bibir, gigi dan palatum

- Disritmia (gagap): kerusakan ritme dan bicara dengan interupsi tiba-tiba dari kecepatan bicara dan pengeluaran suara jarang dapat ditemukan

- Disfonia: kelainan tinggi nada, kualitas dan tingginya suara yang disebabkan oleh kelainan didalam laring, inervasi sarafnya, kelainan psikogenik termasuk suara parau. 
d. Trakhea

Trakea (batang tenggorok) merupakan lanjutan dari laring yang dibentuk oleh 15 sampai dengan 20 cincin yang terdiri dari tulang-tulang rawan yang berbentuk seperti pipa atau kuku kuda (huruf C). Panjang trakea sekitar $13 \mathrm{~cm}$ berdiameter $2,5 \mathrm{~cm}$. Pada pinggir bawah trakea vertebrae torakalis IV, trakea bercabang dua menjadi bronkhus kiri dan bronkhus kanan yang memisahkan trakea menjadi bronkhus kiri dan bronkhus kanan disebut karina.

Fungsi trakea: Submukosa trakea menjadikan dinding trakea kaku dan melindungi serta mencegah trakea mengempis. Kartilago antara trakea dan esofagus lapisannya berubah menjadi elastis pada saat proses menelan sehingga membuka jalan makanan masuk ke lambung. Rangsangansaraf simpatis memperlebar diameter trakea dan mengubah besar volume saat terjadinya perenapasan

e. Bronkus

Bronkhus (cabang tenggorokan) merupakan lanjutan dari trakea yang terdapat dari vertebra torakalis ke-IV dan ke-V. Bronkhus kanan lebih pendek dan lebih besar dari pada bronkhus kiri, terdiri dari 6-8 cincin dan mempunyai tiga cabang. Bronkhus kiri lebih panjang dan lebih ramping dari yang kanan, terdiri dari 9-12 cincin yang mempunyai dua cabang.

Bronkus-bronkus itu berjalan ke bawah dan kesamping ke arah tampuk paru. Bronckus kanan lebih pendek dan lebih lebar, dan lebih vertikal daripada yang kiri, sedikit lebih tinggi darl arteri pulmonalis dan mengeluarkan sebuah cabang utama lewat di bawah arteri, disebut bronckus lobus bawah. Bronkus kiri lebih panjang dan lebih langsing dari yang kanan, dan berjalan di bawah arteri pulmonalis sebelum di belah menjadi beberapa cabang yang berjalan kelobus atas dan bawah.

Cabang utama bronchus kanan dan kiri bercabang lagi menjadi bronchus lobaris dan kernudian menjadi lobus segmentalis. Percabangan ini berjalan terus menjadi bronchus yang ukurannya semakin kecil, sampai akhirnya menjadi bronkhiolus terminalis, yaitu saluran udara terkecil yang tidak mengandung alveoli (kantong udara). Bronkhiolus terminalis memiliki garis tengah kurang lebih I mm. Bronkhiolus tidak diperkuat oleh cincin tulang rawan. Tetapi dikelilingi oleh otot polos sehingga ukurannya dapat berubah. Seluruh saluran udara ke bawah sampai tingkat bronkbiolus terminalis disebut saluran penghantar udara karena fungsi utamanya adalah sebagai penghantar udara ke tempat pertukaran gas paru-paru. 


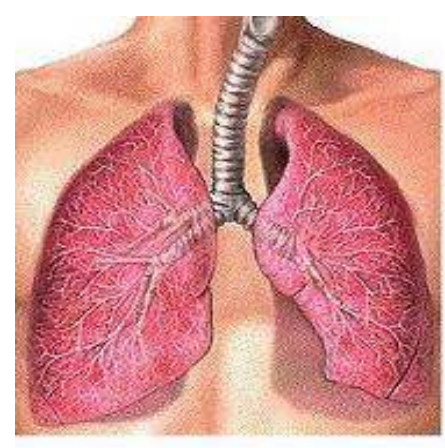

PERCABANGAN BRONKUS

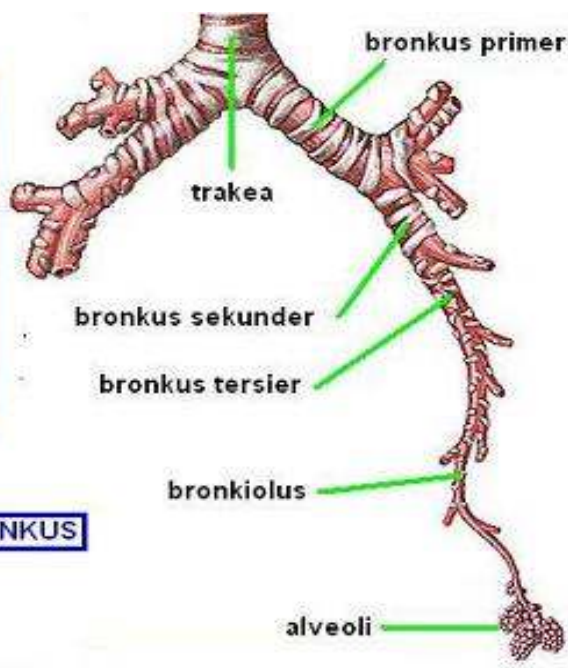

f. Alveoli

Alveolus yaitu tempat pertukaran gas assinus terdiri dari bronkhiolus dan respiratorius yang terkadang memiliki kantong udara kecil atau alveoli pada dindingnya. Ductus alveolaris seluruhnya dibatasi oleh alveoilis dan sakus alveolaris terminalis merupakan akhir paru-paru, asinus atau kadang disebut lobolus primer memiliki tangan kira-kira 0,5 s/d 1,0 cm. Terdapat sekitar 20 kali percabangan mulai dari trachea sampai Sakus Alveolaris. Alveolus dipisahkan oleh dinding yang dinamakan pori-pori kohn. Di sini terjadi pertukaran oksigen dan karbondioksida dari pembuluh darah kapiler dengan udara. Terdapat sekitar 300 juta alveoli di kedua paru dengan diameter masing-masing rata-rata 0,2 milimeter.

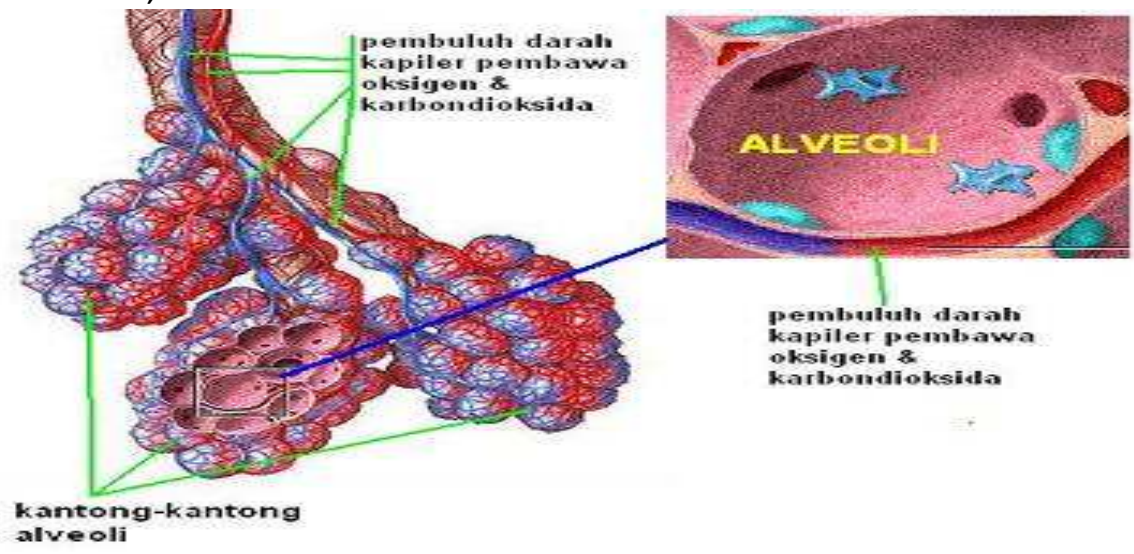

g. Paru-paru

Paru-paru adalah salah satu organ sistem pernapasan yang berada dalam kantong yang dibentuk oleh pleura parietalis dan pleura viseralis. Kedua paru sangat lunak, elastis, dan berada dalam rongga torak. Sifatnya ringan dan terapung dalam air. Paru berwarna biru keabu-abuan dan berbintik-bintik karena partikel-partikel debu yang masuk termakan oleh fagosi.

Masing-masing paru mempunyai apeks yang tumpul menjorok ke atas masuk ke leher kira-kira 2,5 cm di atas klavikula. Fasies kostalis yang konkaf membentuk perikardium. Sekitar pertengahahan permukaan kiri terdapat hilus pulmonalis suatu lekukan tempat bronkhus, pembuluh darah dan saraf masuk ke paru membentuk radiks pulmonalis. 
Paru-paru dibungkus oleh selaput yang disebut pleura. Pleura dibagi menjadi dua yaitu pleura viseral yaitu selaput paru yang langsung membungkus paru-paru dan pleura parietal ini terdapat rongga (kavum) yang disebut kavum pleura. Kavum pleura ini (hampa udara) sehingga paru-paru dapat berkembang kempis dan juga terdapat sedikit cairan (eksudat) yang berguna untuk meminyaki permukaannya, menghindarkan gesekan antara paru-paru dan dinding dada sewaktu ada gerakan bernapas.

Pada waktu inspirasi bagian paru memasuki sinus dan pada waktu ekspirasi ditarik kembali dari rongga tersebut. Sinus pleura ada dua bagian yaitu:

1) Sinus kostomediastinalis: terbentuk pada pertemuan pleura mediastinalis dengan pleura kostalis.

2) Sinus frenikokostalis: terbentuk pada pertemuan pleura diafragmatika dengan pleura kostalis.

Paru-paru dibagi menjadi 2 bagian, yaitu paru-paru kanan dan paru-paru kiri. Basis pulmo adalah bagian yang berada di atas permukaan cembung diapragma, oleh karena kubah diapragma lebih menonjol ke atas, maka bagian kanan lebih tinggi dari paru kiri. Dengan adanya fisura pada permukaan, paru dapat dibagai atas beberapa lobus. Letak insisura dan lobus diperlukan dalam penentuan diagnosis. Pada paru kiri terdapat suatu insisura yaitu insisura obligus yang membagi paru kiri atas dua lobus yaitu lobus superior dan lobus inferior. Paru-paru kanan terdapat dua lobus yaitu insisura obliqua (interlobularis primer) dan insisura interlobularis sekunder.

Paru kanan memiliki 10 segmen yaitu:

1) Lobus superior: segmen apikal, superior, anterior

2) Lobus medius: segmen lateral dan medial

3) Lobus inferior: segmen superior, mediobasal, anterobasal, laterobasal dan posterobasal

Paru kiri terdiri dari 8 segmen yaitu:

1) Lobus superior: segmen apiko posterior, anterior, superior dan inferior

2) Lobus inferior: segmen superior, anteriomediobasal, lateral basal, dan laterobasal 


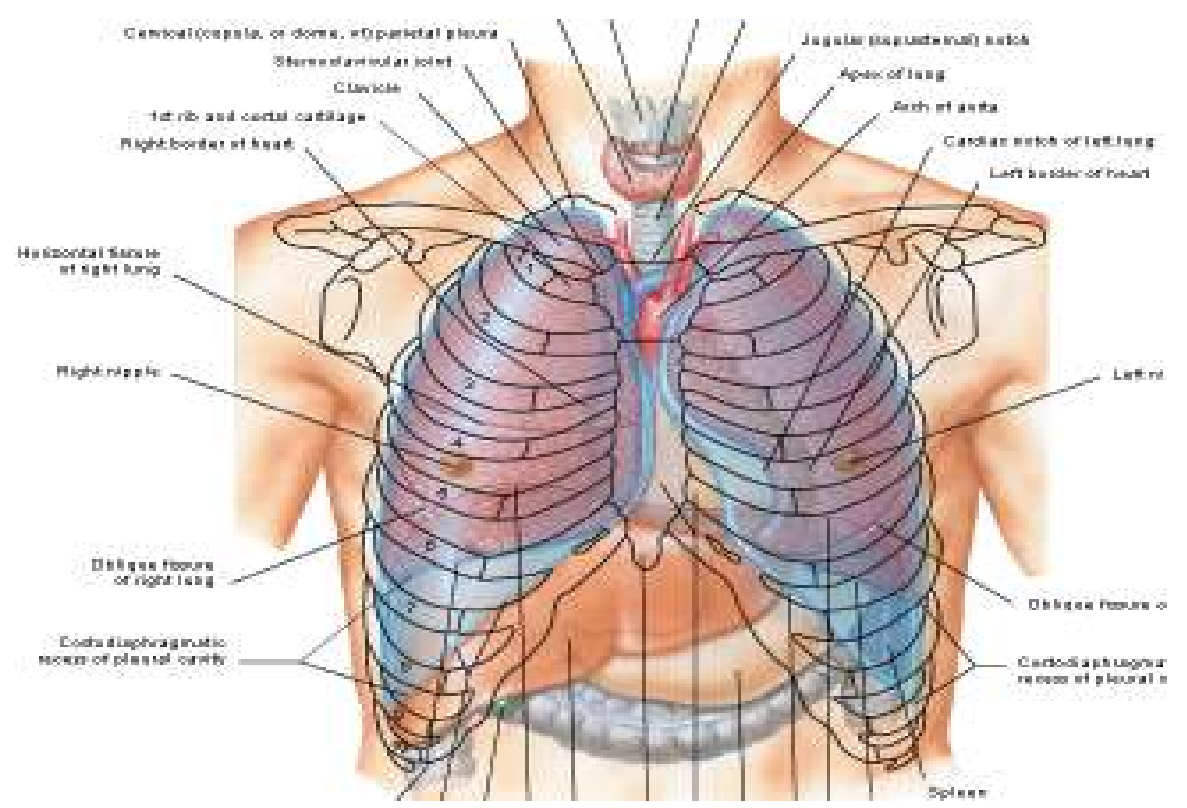

1. Sirkulasi Pulmonal

Paru-paru mempunyai 2 sumber suplai darah, dari arteri bronkialis dan arteri pulmonalis. Darah di atrium kanan mengalir keventrikel kanan melalui katup AV lainnya, yang disebut katup semilunaris (trikuspidalis). Darah keluar dari ventrikel kanan dan mengalir melewati katup keempat, katup pulmonalis, kedalam arteri pulmonalis. Arteri pulmonais bercabangcabang menjadi arteri pulmonalis kanan dan kiri yang masing-masing mengalir keparu kanan dan kiri. Di paru arteri pulmonalis bercabang-cabang berkali-kali menjadi arteriol dan kemudian kapiler. Setiap kapiler memberi perfusi kepada saluan pernapasan, melalui sebuah alveolus, semua kapiler menyatu kembali untuk menjadi venula, dan venula menjadi vena.

Vena-vena menyatu untuk membentuk vena pulmonalis yang besar. Darah mengalir di dalam vena pulmonalis kembali keatrium kiri untuk menyelesaikan siklus aliran darah. Jantung, sirkulasi sistemik, dan sirkulasi paru. Tekanan darah pulmoner sekitar $15 \mathrm{mmHg}$. Fungsi sirkulasi paru adalah karbondioksida dikeluarkan dari darah dan oksigen diserap, melalui siklus darah yang kontinyu mengelilingi sirkulasi sistemik dan paru, maka suplai oksigen dan pengeluaran zat-zat sisa dapat berlangsung bagi semua sel.

\section{FISIOLOGI PERNAFASAN}

\section{Mekanisme Pernafasan}

Paru dan dinding dada adalah struktur yang elastis dalam keadaan normal. Terdapat lapisan cairan tipis antara paru dan dinding dada. Paru dengan mudah bergeser pada dinding dada. Tekanan pada ruangan antara garis dinding dada dibawah tekanan atmosfer. Paru berkembang pada waktu bayi baru lahir.

Pada waktu menarik nafas dalam, otot berkontraksi tetapi pengeluaran pernafasan dalam proses yang pasif. Diafragma menutup ketika pergerakan napas, rongga dada kembali membesar paru, dinding badan bergerak diafragma dan tulang dada menutup ke posisi semula. Aktifitas bernafas merupakan dasar yang meliputi gerak tulang rusak ketika bernafas dalam dan volume udara bertambah. 
Pada waktu inspirasi udara melewati hidung dan laring. Udara dihangatkan dan diambil uap airnya. Udara berjalan melalui trakhea, bronkus dan duktus alveolaris ke alveoli. Alveoli dikelilingi oleh kapiler- kapiler. Terdapat kira-kira 300 juta alveoli. Aktivitas bernafas merupakan dasar yang meliputi gerak tulang sewaktu bernafas dalam. Pada waktu istirahat pernafasan menjadi dangkal akibat tekanan abdomen yang membatasi gerakan diafragma.

\section{INSPIRASI}

Inspirasi adalah proses aktif kontraksi otot-otot inspirasi yang menaikkan volume intratoraks. Selama bernapas tenang tekanan intrapleura kira-kira $2,5 \mathrm{mmHg}$ (relatif terhadap atmosfer). Pada permulaan inspirasi menurun sampai $-6 \mathrm{mmHg}$ dan paru ditarik ke arah posisi yang lebih mengembang, dijalan udara menjadi sedikit negatif dan udara mengalir kedalam paru. Akhir respirasi rekoil menarik kembali ke posisi ekspirasi karena tekanan rekoli paru dan dinding dada seimbang. Tekanan dalam jalan pernapasan seimbang menjadi sedikit positif, udara mengalir keluar dari paru.

Pada saat inspirasi, pengaliran udara ke rongga pleura dan paru berhenti sebentar ketika tekan dalam paru bersamaaan bergerak mengelilingi atmosfer. Pada waktu penguapan pernapasan, volume sebuah paru berkurang karena naiknya tekanan udara untuk memperoleh dorongan keluar pada sistem pernapasan.

\section{EKSPIRASI}

Pernapasan tenang bersifat pasif tidak ada otot-otot yang menurunkan volume untuk toraks berkontraksi permulaan ekspirasi kontraksi ini menimbulkan kerja yang menahan kekuatan rekoil dan melambatkan ekpirasi. Inspirasi yang kuat berusaha mengurangi tekanan intrapleura sampai serendah $30 \mathrm{mmHg}$, ini menimbulkan pengembangan paru dengan derajat yang lebih besar. Bila ventilasi meningkat, luasnya delasi paru meningkat dengan kontraksi otot-otot pernapasan, yang menurunkan volume intratoraks.

Tekanan intrapleura adalah tekanan ukuran dalam antara lapisan pleura dan lapisan pleura dalam. Pleura parietal dan pleura viseral dipisahkan oleh selaput tipois pleura yang berisi zat dan gas.

\section{VOLUME DAN KAPASITAS PARU}

Metoda yang sederhana untuk meneliti ventilasi paru adalah dengan merekam volume pergerakan udara yang masuk dan keluar paru. Alat yang digunakan dinamakan spirometri atau spirogram yang dapat memperlihatkan perubahan dalam volume paru pada berbagai keadaan pernapasan.

\section{Volume Paru}

Ada empat volume paru bila semua dijumlahkan sama dengan volume maksimal paru yang mengembang, masing-masing volume itu adalah:

1. Volume tidal

Merupakan volume udara yang diinspirasikan dan diekspirasikan di setiap pernapasan normal, jumlahnya kira-kira $500 \mathrm{ml}$

2. Volume cadangan inspirasi

Merupakan volume tambahan udara yang dapat diinspirasikan diatas volume tidal normal, biasanya $3000 \mathrm{ml}$. 
3. Volume cadangan ekspirasi

Merupakan jumlah udara yang masih dapat dikeluarkan dengan ekpirasi tidal yang normal, jumlahnya lebih kurang $1.100 \mathrm{ml}$

4. Volume sisa

Volume udara yang masih tersisa di dalam paru setelah kebanyakan ekspirasi kuat, volume ini rata-rata $1.200 \mathrm{ml}$.

Ventilasi paru normal hampir sepenuhnya dilakukan oleh otot-otot inspirasi, pada waktu otot inspirasi berelaksasi sifatnya elastis, paru dan toraks mengempis secara pasif. Bila semua otot berelaksasi kembali ke suatu keadaan istirahat. Volume udara di dalam paru pada tingkat yang sama dengan kapasitas fungsional kira-kira $2.300 \mathrm{ml}$.

\section{Volume Sisa}

Udara yang tidak bisa dikeluarkan dari paru bahkan dengan ekpsirasi yang kuatpun tidak bisa dikeluarkan, fungsinya menyediakan udara dalam alveolus untuk menyerasikan darah diantara dua siklus pernapasan. Seandainya tidak ada udara sisa, konsentrasi oksigen dan karbondioksida di dalam darah akan naik dan turun secara jelas.

\section{Volume Respirasi Permenit}

Volume respirasi permenit adalah jumlah total udara baru yang masuk kedalam saluran pernapasan setiap menit, sama dengan volume tidal kecepatan respirasi. Volume tidal normal sekitar $500 \mathrm{ml}$ dan kecepatan respirasi normal 12 kali permenit. Rata-rata volume respirasi permenit sekitar 6 liter/menit. Sedikitnya 1,5 liter dan kecepatan respirasi serendahnya 2-4 kali permenit.

Kecepatan respirasi kadang-kadang mencapai 40-50 kali permenit dan volume tidal dapat menjadi sama besar dengan kapasitas vital, kira-kira $4.600 \mathrm{ml}$ pada pria dewasa muda. Kecepatan bernapas tinggi tidak dapat mempertahankan suatu volume tidal yang lebih besar dari setengah kapasitas vital, dengan mengombinasikan kedua faktor ini laki-laki dewasa muda mempunyai kapasitas pernapasan maksimum 100-120 liter/menit.

Kapasitas Paru

\section{VENTILASI PARU}

Ventilasi Mekanis

Udara mengalir dari tekanan tinggi ke bagan tekanan rendah. Namun demikian bila tidak ada uadar masuk atau keluar dari paru tekanann alveolar dan atmosfer dalam keadaan seimbang. Untuk memulai pernapasan aliran udara dalam paru-paru harus dicetuskan oleh turunnya tekanan dalam alveoli. Ini melibatkan adanya elastisitas, komplain, tekanan dan graviatsi:

1) Elastisitas: Kembalinya bentuk asli setelah perubahan karena kekuatan dari luar. Paru dan dada bersifat elastis, memerlukan energi untuk bergerak dengan cepat, dan kembali ke bentuk awalnya bila energi tidak efetif lagi.

2) Komplain: Kemampuan mengembang paru, merupakan ukuran elastissitas, ditunjukkan sebagai peningkatan volume dalam paru, untuk tiap unit peningkatan tekanan intraalveolar.

$$
\begin{aligned}
& \text { Komplain }=\frac{\text { Perubahan Volume Paru (Liter) }}{\text { Perubahan tekanan paru }(\mathrm{cm} \mathrm{H} 2 \mathrm{O})} \\
& \text { Komplain paru total pada kedua paru adalah 0,13 L/cm. }
\end{aligned}
$$


3) Tekanan: Udara yang ditangkap jalan napas adalah campuran nitrogen dan oksigen $(99,5 \%)$ dan sejumlah kecil karbon dioksida dan uap air $(0,5 \%)$. Volume gas menimbulkan tekakanan terhadap dinding penampung karena gas dan campuran gas berusaha untuk bergerak dari batas lingkungan yang ada.

4) Gravitasi: Adalah akibat banyaknya pertukaran udara yang terjadi pada bagian atas paru dari pada dasar paru. Kekuatan gravitasi meningkatkan jumlah upaya ynag dibutuhkan untuk ventialsi bagian paru yang tergantung, menyebabkan pertukaran dalam ventilasi diaman ventilasi bagian ini menurun dan ventialsi lain dari area yang kurang meningkat.

\section{Cara Kerja Pernapasan}

Jika kita bernapas dengan kuat maka paru akan mengembang dengan kapasitas maksimum, permukaan dada mengeluarkan tekanan yang berbeda. Oleh karena kekuatan yang lebih dari kekuatan elastis akan membesar menyebabkan volume akan meninggi. Alat untuk mengukur muatan pernapasan, persediaan pengeluaran dan persendian pemasukan sangat penting.

a. Pernapasan luar: kecenderungan kekuatan tekanan molekul gas meningkat sampai pada ketidakseimbangan menjadi tidak stabil, ketika ketidakseimbangan molekul gas dalam ruang difusi luar tidak sampai keseluruh molekul gas. Kembalinya tekanan meningkatnya akan bertambah besar pada penghancuran molekul tekanan akan berkurang akibat pergerakan molekul gas

b. Pernapasan dalam: normal cairan intertisial dari PO2 adalah $40 \mathrm{mmHg}$ dan PCO2 $45 \mathrm{mmHg}$. Sebagai hasil, oksigen (O2) disebabkan keluar pembuluh kapiler sampai tekanan bagian kapiler sama dengan bagian membran. Darah vena keluar dari kapiler akan ditransfor kesirk

\section{Ruang Rugi}

Sebagian udara yang dihirup oleh seseorang tidak pernah sampai pada daerah pertukaran gas, tetapi tetap berada dalam saluran napas. Tempat tidak terjadi pertukaran gas di setiap kali bernapas dinamakan udara ruang rugi. Pada inspirasi banyak udara baru mula-mula harus mengisi berbagai area ruang rugi jalan napas (mis,hidung, faring, trakea dan bronkus) sebelum mencapai alveoli. Udara ruang rugi ini tidak berguan bagi proses pertukaran gas, karena di lokasi ini tidak terjadi pertukaran gas. Udara ruang rugi normal pada orang muda dewasa kira-kira $150 \mathrm{ml}$.

Prinsip Fisis Pertukaran Gas

Setelah udara alveolus ditukar dengan udara segar, langkah selanjutnya dalam proses respirasi adalah difusi oksigen dari alveolus kedalam darah paru dan karbondioksida dalam darah berlawanan dari darah paru kedalam alveolus. Semua gas yang dipertimbangkan dalam fisiologis pernapasan merupakan molekul sederhanan yang bebas bergerak diantara satu dengan yang lain, dinamakan proses difusi dari gas-gas yang larut dalam cairan dan jaringan tubuh. Untuk terjadinya difusi harus ada sumber energi yang di selenggarakan oleh gerakan kinetik molekul itu sendiri, sehingga semua molekul pada keadaan apapun secara terus menerus mengalami beberapa jenis gerakan, untuk molekul bebas secara fisik tidak melekat satu sama lain, berarti gerakan linier molekul pada kecepatan tinggi sampai beradu dengan molekul lain dengan cara ini molekul bergerak cepat di antara satu dengan yang lain. 


\section{Tekanan Uap Air}

Semua gas dalam tubuh berhubungan langsung dengan air dan semua campuran gas jenuh dengan uap air. Tekanan uap air sama sekali bergantung pada suhu, semakin tinggi suhu semakin besar aktifitas molekul dalam air, semakin besar molekul ini keluar dari permukaan air masuk kedalam fase gas. Pada saat udara kering tiba-tiba dicampur dengan air dengan tekanan uap air mula-mula nol, molekul air segera mulai keluar dari permukaan air ke dalam udara tersebut. Udara menjadi lebih lembab secara profresif tercapai suatu keseimbangan tekan uap. Saat ini kecepatan kondensasi air menjadi sama dengan penguapan air.

Difusi Gas Melalui Jaringan

Yang penting dalam gas-gas pernapasan/respirasi adalah daya larut yang sangat tinggi dalam lemak, akibatnya juga sangat larut dalam membran sel. Gas ini berdifusi melalui membran sel dengan rintangan. Pembatas utama gerakan gas didalam jaringan adalah kecepatan difusi melalui cairan jaringan bukan melalui membran sel. Oleh karena itu difusi gas melalui air, terutama yang harus diperhatikan bahwa karbondioksida berdifusi 20 kali kecepatan oksigen.

Faktor-faktor yang menentukan kecepatan difusi gas:

1. Ketebalan membran pernapasan: ketebalan membran ini dapat menghalangi pertukaran secara bermakna

2. Luas permukaan membran pernapasan: bila jumlah total permukaan dikurangi pertukaran gas melalui membran tersebut sangat terganggu.

3. Koefisien difusi gas dalam substansi membran: memindahkan masing-masing gas melalui membran pernapasan bergantung pada kelarutannya, kecepatan difusi karbondioksida melalui membran 20 kali kecepatan oksigen.

4. Perbedaan tekanan antara kedua sisi membran: tekanan parsial gas dalam alveoli lebih besar daripada tekanan gas dalam darah, maka terjadi difusi netto dari alveoli ke dalam darah begitu juga sebaliknya.

Transpor Gas Antara Paru dan Jaringan

Selisih tekanan parsial antara $\mathrm{O} 2$ dan $\mathrm{CO} 2$ merupakan kunci dari pergerakan gas $\mathrm{O} 2$ yang mengalir dari alveoli masuk ke dalam jaringan melalui darah. Sedangkan CO2 mengalir dari jaringan ke alveoli melalui pembuluh darah. Akan tetapi jumlah kedua gas yang ditranspor ke jaringan dan dari jaringan secara keseluruhan tidak cukup bila seandainya $\mathrm{O} 2$ tidak larut dalam darah bergabung dengan protein pembawa $\mathrm{O} 2$ (hemoglobin).

Demikian juga CO2 yang larut masuk ke dalam serangkaian reaksi kimia reversibel yang mengubah menjadi senyawa lain, adanya hemoglobin menaikkan kapasitas pengangkuitan O2 dalam darah sampai 70 kali dan reaksi $\mathrm{CO} 2$ menaikkan kadar4 $\mathrm{CO} 2$ dalam darah menjadi 17 kali.

Pengangkutan Oksigen Ke jaringan

Sistem pengangkutan $\mathrm{O} 2$ dalam tubuh terdiri dari paru dan sistem kardiovarkuler. $\mathrm{O} 2$ masuk ke jaringan bergantung pada jumlah $\mathrm{O} 2$ yang masuk kedalam paru. Pertukaran gas yang cukup pada paru, aliran darah ke jaringan, dan kapasitas pengangkutan $\mathrm{O} 2$ oleh darah. Aliran darah bergantung pada derajat konsentrasi (vaskuler bed) dalam jaringan dan curah jantung (cardiac output). Jumlah $\mathrm{O} 2$ dalam darah ditentukan oleh jumlah $\mathrm{O} 2$ yang larut, hemoglobin dan afinitas hemoglobin. 
Kecepatan Pertukaran Gas melintasi membran alveolus

\begin{tabular}{|c|c|c|}
\hline Faktor & Pengaruh Kecepatan & Komentar \\
\hline $\begin{array}{l}\text { Gradieri tekanan parsial } \\
\mathrm{O} 2 \text { dan } \mathrm{CO} 2\end{array}$ & $\begin{array}{lr}\text { Kecepatan pertukaran } \\
\text { meningkat jika gradien } \\
\text { tekanan } \\
\text { meningkat } & \\
\end{array}$ & $\begin{array}{l}\text { Penentu } \\
\text { kecepatan }\end{array}$ \\
\hline $\begin{array}{l}\text { Luas permukaan } \\
\text { memberan alveolus }\end{array}$ & $\begin{array}{l}\text { Kecepatan pertukaran } \\
\text { meningkat jika luas } \\
\text { permukaan meningkat }\end{array}$ & $\begin{array}{l}\text { Luas permukaan bersifat } \\
\text { tetap pada keadaan } \\
\text { istirahat. } \\
\text { permukaan meningkat } \\
\text { selama olahraga, karena } \\
\text { semakin banyak jumlah } \\
\text { kapiler paru yang } \\
\text { terbuka saat curah } \\
\text { jantung meningkat dan } \\
\text { alveolus lebih banyak } \\
\text { yang mengembnag } \\
\text { karena lap } \\
\text { menjadi lebih dalam. } \\
\text { Luas pernapas } \\
\text { menurun pada keadaan } \\
\text { patologis, misal pada } \\
\text { emfisema } \\
\text { atelektasis. }\end{array}$ \\
\hline $\begin{array}{l}\text { Ketebalan sawar } \\
\text { memisahkan udara dan } \\
\text { darah melintasi } \\
\text { memberan alveolus }\end{array}$ & $\begin{array}{lr}\text { Kecepatan } & \text { pertukaran } \\
\text { meningkat } & \text { jika } \\
\text { koefisien } & \text { difusi } \\
\text { meningkat } & \end{array}$ & $\begin{array}{l}\text { Dalam keadaan normal, } \\
\text { ketebalan tidak } \\
\text { berubah, ketebalan } \\
\text { meningkat pada } \\
\text { keadaan patologis, } \\
\text { misalnya edema paru } \\
\text { fibrosa paru dan } \\
\text { pneumonia. }\end{array}$ \\
\hline $\begin{array}{ll}\text { Koefisien difusi } & \text { (daya } \\
\text { larut gas } & \text { dalam } \\
\text { memberan) } & \end{array}$ & $\begin{array}{lr}\text { Kecepatan } & \text { pertukaran } \\
\text { meningkat } & \text { jika } \\
\text { koefisisen } & \text { difusi } \\
\text { meningkat } & \end{array}$ & $\begin{array}{l}\text { Koefisien difusi untuk } \\
\text { CO2 lebih besar } 20 \text { kali } \\
\text { dibandingkan dengan } \\
\text { O2, mengimangi gradien } \\
\text { tekanan parsial } \mathrm{CO} 2 \\
\text { yang lebih kecil, dengan } \\
\text { demikian o2 dan CO2 } \\
\text { yang dipindahkan }\end{array}$ \\
\hline
\end{tabular}




\begin{tabular}{|l|l|l|}
\hline & & $\begin{array}{l}\text { menembus memberan } \\
\text { kira-kira setara }\end{array}$ \\
\hline
\end{tabular}

Transpor oksigen melalui beberapa tahap:

1. Tahap I. Oksigen dari atmosfer masuk kedalam paru pada waktu kita menarik napas. Tekanan parsial oksigen dalam atmosfer $159 \mathrm{mmHg}$, dalam alveoli komposisi udara berbeda dengan komposisi udara atmosfer. Tekanan parsial 02 dalam alveoli $105 \mathrm{mmHg}$.

2. Tahap II. Darah mengalir dari jantung menuju keparu untuk mengambil oksigen, yang berada dalam alveoli. Dalam darah ini terdapat oksigen yang mempunyai tekanan partial $40 \mathrm{mmHg}$. Karena adanya perbedaan tekanan parsial itu, bila tiba pada pembuluh kapiler yang berhubungan dengan membran alveoli maka oksigen yang berada dalam alveoli dapat berdifusi masuk kedalam pembuluh kapiler. Setelah terjadi proses difusi tekanan parsial oksigen dalam pembuluh darah menjadi $100 \mathrm{mmHg}$.

3. Tahap III. Oksigen yang telah berada dalam pembuluh darah di edarkan keseluruh tubuh. Ada dua mekanisme peredaran oksigen dalam darah, yaitu oksigen yang larut dalam plasma darah merupakan bagian yang terbesar dan sebagian kecil oksigen yang terikat pada hemoglobin dalam darah. Derajat kejenuhan hemoglobin dengan $\mathrm{O} 2$ bergantung pada tekanan parsial $\mathrm{CO} 2$ atau $\mathrm{pH}$ dan jumlah $\mathrm{O} 2$ yang diangkut ke jaringan bergantung pada jumlah $\mathrm{Hb}$ dalam darah.

4. Tahap IV. Sebelum sampai pada sel yang membutuhkan oksigen dibawa melalui cairan interstisial lebih dahulu. Tekanan parsial oksigen dalam cairan intertisial $20 \mathrm{mmHg}$. Perbedaan tekanan parsial oksigen dalam pembuluh darah arteri $(100 \mathrm{mmHg}$ ) dengan tekanan parsial oksigen dalam cairan intertisial $(20 \mathrm{mmHg})$ menyebabkan terjadinya difusi oksigen yang cepat dari pembuluh kapiler ke dalam cairan intertisial.

5. Tahap V. Tekanan parsial oksigen dalam sel kira-kira antara $0-20 \mathrm{mmHg}$. Oksigen dari cairan intertisial berdifusi masuk ke dalam sel. Dalam sel oksigen ini digunakan untuk reaksi metabolisme yaitu reaksi oksidasi senyawa yang berasal dari makanan (karbohidrat, lemak dan protein) menghasilkan $\mathrm{H} 2 \mathrm{O}$ dan $\mathrm{CO} 2$. Energi penggunaan oksigen oleh sel dan transpor $\mathrm{CO} 2$ keluar dari sel dan masuk ke dalam pembuluh vena.

Reaksi Hemoglobin dan Oksigen

Dimana reaksi hemoglobin sangat cocok untuk mengangkut O. Hemoglobin lobin adalah protein yang terikat pada rantai poli peptida yang dibentuk oleh porfirin dan satu atom besi ferro. Masing-masing atom besi dapat mengikat secara reversibel dengan satu molekul $\mathrm{O} 2$. Besi berada dalam bentuk ferro sehingga reaksinya adalah oksigenasi bukan oksidasi.

Tranpor Karbondioksida

Kelarutan $\mathrm{CO} 2$ dalam darah kira-kira 20 kali kelarutan $\mathrm{O} 2$ sehingga terdapat lebih banyak $\mathrm{CO} 2$ daripada 02. Dalam larutan sederhana $\mathrm{CO} 2$ berdifusi dalam sel darah merah dengan cepat mengalami hidrasi menjadi $\mathrm{H} 2 \mathrm{CO} 3$, sebab adanya anhidrase (berkurangnya sekresi keringat) karbonat berdifusi ke dalam plasma. Penurunan kejenuhan hemoglobin terhadap $\mathrm{O} 2$ waktu darah melalui kapiler jaringan memperbaiki kapasitas dat sebab deoksigeneted hemoglobin mengikat lebih banyak $\mathrm{H}+$ lebih daripada oksihemoglobin. Sebagian dari $\mathrm{CO} 2$ dalam sel darah merah bereaksi dengan gugus amino dari protein, hemoglobin membentuk senyawa karbamino. 
Besarnya kenaikan kapasitas darah mengangkut $\mathrm{CO} 2$ yang ditunjukkan oleh selisih antara garis kelarutan $\mathrm{CO} 2$ dan garis kadar total CO2. Diantara $49 \mathrm{ml}$ CO2 dalam darah arterial 2,6 $\mathrm{ml}$ adalah senyawa karbamino dan $43,8 \mathrm{ml}$ dalam $\mathrm{HCO}$. Dalam jaringan $3,7 \mathrm{ml} \mathrm{CO} 2+0,4$ berada dalam larutan, 0,8 ml membentuk senyawa karbamino dan 2,5 membentuk HCO3. $\mathrm{pH}$ darah turun dari 7,4 menjadi 7,36 dalam paru, proses dibalik 3,7 ml CO2 dilepaskan kedalam alveoli. Dalam bentuk ini $200 \mathrm{ml} \mathrm{CO2}$ per menit waktu istirahat dan jumlah ini lebih banyak waktu bekerja ditranspor dari jaringan ke paru dan dieksresikan.

Proses Transpor Oksigen

Saturasi (kejenuhan) hemoglobin dan PO2 hanya mengelilingi 3\% dari oksigen yang terdiri dari darah arteri. Konsentrasi molekul oksigen dalam larutan cadangan dari molekul hemoglobin, khususnya panas atom di dalam unit pusat adalah $\mathrm{HB}+\mathrm{O} 2=\mathrm{HBO} 2$.

Molekul hemoglobin oksigen segera berkembang pada keadaan seimbang. Jika dari semua hemoglobin ini menggantikan $\mathrm{HBO} 2$ darah ini $100 \%$ oksigenasi atau pemenuhan bersama oksigen terjadi. Sebagian PO2 mencapai permukaan lebih tinggi sekitar $250 \mathrm{mmHg}$. Pada konsentrasi oksigen rendah, darah hanya memenuhi sebagian, tetapi tekanan alveolar pemenuhannya masih tinggi. Hemoglobin mempunyai oksigen kuat pada konsentrasi udara alveolar $97,5 \%$ dari hemoglobin dalam bentuk $\mathrm{HBO}$.

Oksigen darah ini datang dari kapiler perifer, PO2 mulai turun. Gangguan keseimbangan ini kunci reaksi, seperti konsentrasi plasma pada oksigen yang turun. Sebaliknya mempercepat reaksi lebih dari cukup memberikan hemoglobin ini oksigen, pemenuhan hemoglobin berlawanan dengan $\mathrm{PO}$.

Percampuran Gas dalam Hukum Alton

Udara pernapasan bukan gas tunggal tetapi gas campuran. Molekul nitrogen (N2) paling banyak $78,5 \%$ dari total molekul atmosfer gas. Molekul oksigen $21 \%$ molekul air $0,5 \%$ dan molekul CO2 0,04\%.

Tekanan atmosfer $760 \mathrm{mmHg}$. Efek perpaduan melibatkan setiap tipe dari molekul pada setiap saat perpaduan ini konsentrasi tiap gas dari total tekanan. Perbandingan dikenal sebagai hukum Dalton. Kontribusi tekanan oleh gas tunggal mewakili tekanan parsial dari gas itu, disingkat dengan "P". Semua tekanan parsial ditambah tekanan total yang diserap campuran gas, hubungan atmosfer disingkat.

$\mathrm{PN} 2+\mathrm{PO} 2+\mathrm{PH} 2 \mathrm{O}+\mathrm{PCO} 2=760 \mathrm{mmHg}$

Sebagian tekanan pada gas dapat diperkirakan, misalnya tekanan oksigen PO2 $(21 \%$ x 760 $\mathrm{mmHg}=160 \mathrm{mmHg}$ ). Di perkirakan difusi pada gas, khususnya dari kelarutan udara, bergantung pada kesatuan sebagian tekanan gas. Sejumlah tekanan diserap dari molekul oksigen memakai cukup banyak oksigen dan mempunyai efek perbandingan pada difusi nitrogen dan $\mathrm{CO} 2$.

Pernapasan dan Pertukaran $\mathrm{O} 2$ dan $\mathrm{CO} 2$ dalam alveolar

Pada saat menarik napas $500 \mathrm{ml}$ udara masuk kedalam pernapasan, pertukaran melalui rongga hidung udara, dihangatkan, uap air bertambah pada pernapasan pertama inspirasi, $350 \mathrm{ml}$ masuk keruangan alveolar bercampur dengan bekas udara alveoli. Setelah pernapasan 
berisi > $\mathrm{CO} 2$ dan < $\mathrm{O} 2$ dari udara atmosfer, selama inspirasi alveolar menghubungkan udara dengan air campuran ini. Perbedaan susunan atmosfer dengan alveolar menunjukkan sebagian tekanan darah dari arteri dan vena darah mengalir ke kapiler paru mengangkat PO2 dari darah dan mengurangi PCO2. Waktu darah masuk ke vena paru-paru mencapai keseimbangan di alveolar, bertolak dari PO2 100 mmHg dan PCO2 40 mmHg darah dari perifer mempunyai sedikit muatan $\mathrm{O} 2$. Hal ini disebabkan darah masuk kesirkulasi vena pulmonalis kapiler penghantar berjalan menuju alveoli. Oksigenasi darah ini bercampur dengan oksigenasi darah dari vena pulmonalis. Reduksi PO2 sekitar $95 \mathrm{mmHg}$ tidak menukar konsentrasi gas darah menuju ke kapiler perifer.

\section{PENGATURAN PERNAPASAN}

Pernapasan spontan ditimbulkan oleh rangsangan ritmis neuron motoris yang mempersarafi otot pernapasan otak. Rangsangan ini secara keseluruhan bergantung pada impuls-impuls saraf. Pernapasan berhenti bila medula spinalis melintang di atas nervus prenikus.

Terdapat dua mekanisme saraf yang terpisah mengatur pernapasan dan terdapt pada korteks serebri. Rangsangan ritmik pada medula oblongata menimbulkan pernapasan otomatis. Daerah medula oblongata berhubungan dengan pernapasan secara klasik. Rangsangan ritmis neuron pusat pernapasan.

Variabel Terkait $\mathrm{O} 2$ dan $\mathrm{CO} 2$ selama olah raga

\begin{tabular}{|l|l|l|}
\hline Variabel Terkait O2 dan CO2 & Perubahan & Komentar \\
\hline Pemakaian Oksigen & Sangat meningkat & $\begin{array}{l}\text { Otot yang aktif mengoksidasi } \\
\text { molekul nutrien lebih cepat } \\
\text { untuk memuhi } \\
\text { peningkatan kebutuhan } \\
\text { enrginya. }\end{array}$ \\
\hline Produksi CO2 & Sangat meningkat & $\begin{array}{l}\text { Otot yang lebih aktif } \\
\text { melakukan metabolisme, } \\
\text { memproduksi lebih banyak } \\
\text { CO2 }\end{array}$ \\
\hline PO2 Arteri & $\begin{array}{l}\text { Normal atau sedikit } \\
\text { meningkat }\end{array}$ & $\begin{array}{l}\text { Walaupun pemakaian O2 } \\
\text { dan produksi cO2 sangant } \\
\text { meningkat, ventilasi alveolus } \\
\text { mengimbangi atau bahkan } \\
\text { sedikit melebihi }\end{array}$ \\
\hline PCO2 Arteri & $\begin{array}{l}\text { Normal atau sedikit } \\
\text { meningkat }\end{array}$ & $\begin{array}{l}\text { Sedikit melebihi peningkatan } \\
\text { kecepatan emakaian O2 dan } \\
\text { produksi CO2 }\end{array}$ \\
\hline Penyaluran O2 ke otot & Sangat meningkat & $\begin{array}{l}\text { Walaun PO2 arteri tetap } \\
\text { normal, penyaluran O2 ke } \\
\text { otot sangat meningkat } \\
\text { karena peningkatan aliran } \\
\text { darah keotot melalui } \\
\text { peningkatan curah jantung } \\
\text { dan vasodilatasi lokal di } \\
\text { otot-otot yang aktif }\end{array}$ \\
\hline
\end{tabular}




\begin{tabular}{|c|c|c|}
\hline Ekstraksi $\mathrm{O} 2$ oleh Otot & Sangat meningkat & 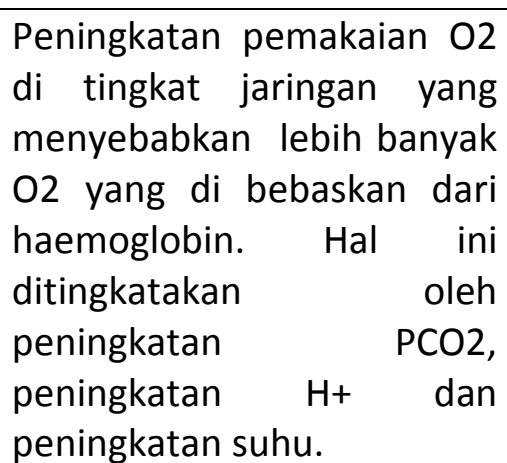 \\
\hline Penggunaan $\mathrm{CO} 2$ dari otot & Sangat meningkat & $\begin{array}{l}\text { Aliran darah yang meningkat } \\
\text { ke otot mengurnagi } \\
\text { kelebihan CO2 yang } \\
\text { diahsilkan oleh jaringan yang } \\
\text { melakukan metabolisme } \\
\text { lebih aktif. }\end{array}$ \\
\hline $\begin{array}{l}\text { Konsentrasi } \mathrm{H}+\text { Olahraga } \\
\text { arteri ringan sampai sedang }\end{array}$ & Normal & $\begin{array}{l}\text { Karena } \mathrm{CO} 2 \text { penghasil asam } \\
\text { karbonat di dalam darah, } \\
\text { arteri dijaga konsentrasi } \\
\text { konstan } \mathrm{H}+\text { arteri tidak } \\
\text { berubah. }\end{array}$ \\
\hline Olahraga Berat & Peningkatan sedang & $\begin{array}{l}\text { Pada olahraga berat, ketika } \\
\text { otot mengandalkan } \\
\text { metabolisme anaerob } \\
\text { terjadi penambahan asam } \\
\text { laktat dan darah }\end{array}$ \\
\hline
\end{tabular}

\section{Pengaturan Oksigen Darah}

Biasanya kira-kira 97\% oksigen ditanspor dari paru kejaringan, diangkut dalam kombinasi kimia dengan hemoglobin di dalam sel darah merah. Sisanya 3\% diangkut dalam keadaan terlarut di dalam air plasma dan sel. Dalam keadaan normal, transpor oksigen dalam keadaan terlarut,

Aksi Otot-Otot pernapasan

\begin{tabular}{|l|l|l|}
\hline Otot & Hasil Kontraksi Otot Stimulasi \\
\hline Otot inspirasi Diafragma & $\begin{array}{l}\text { Bergerak turun } \\
\text { meningkatkan dimensi } \\
\text { ventrikel toraks }\end{array}$ & $\begin{array}{l}\text { Waktu } \\
\text { Serkontraski otot primer inspirasi }\end{array}$ \\
\hline Otot antar-lga Eksterna & $\begin{array}{l}\text { Mengangkat iga kearah } \\
\text { depan dan kearah luar, } \\
\text { memperbesar rongga toraks } \\
\text { dalam dimensi depan ke } \\
\text { belakang dan sisi-sisi. }\end{array}$ & $\begin{array}{l}\text { Setiap inspirasi berperan } \\
\text { sekunder terhadap aksi } \\
\text { primer diafragma }\end{array}$ \\
\hline $\begin{array}{l}\text { Otot-otot Leher skalenus, } \\
\text { Sternokleidomastoideus }\end{array}$ & $\begin{array}{l}\text { Mengangkat sternum dan } \\
\text { dua iga pertama, } \\
\text { memperbesar bagian atas } \\
\text { rongga dada }\end{array}$ & $\begin{array}{l}\text { Hanya pada saat inspirasi } \\
\text { paksa, otot inspirasi } \\
\text { tambahan. }\end{array}$ \\
\hline
\end{tabular}




\begin{tabular}{|c|c|c|}
\hline $\begin{array}{l}\text { Otot-otot Ekspirasi Otot } \\
\text { Abdomen }\end{array}$ & $\begin{array}{l}\text { Meningkatkan tekanan intra } \\
\text { abdomen yang } \\
\text { menimbulkan gaya ke atas } \\
\text { pada diafragma untuk } \\
\text { mengurangi dimensi vertikal } \\
\text { rongga toraks }\end{array}$ & $\begin{array}{l}\text { Hanya pada saat ekspirasi } \\
\text { akut atau paksa }\end{array}$ \\
\hline Otot-otot atar-iga Internal & $\begin{array}{lr}\text { Mendatarkan torakas } \\
\text { dengan menarik iga-iga ke } \\
\text { bawah dan dalam } \\
\text { menurunkan ukuran depan } \\
\text { belakang dan samping } \\
\text { rongga toraks }\end{array}$ & $\begin{array}{l}\text { Hanya sewaktu ekspirasi } \\
\text { akut atau paksa. }\end{array}$ \\
\hline
\end{tabular}

\section{Pengangkutan Karbondoiksida dalam Darah}

Transpor karbondioksida bukan hal sebesar transpor oksigen karena dalam keadaan abnormalpun karbondioksida biasanya dapat ditranspor oleh darah darah dalam jumlah yang jauh lebih besar daripada oksigen. Tetapi jumlah karbondioksida dalam darah berhubungan erat dengan keseimbangan asam basa cairan tubuh. Dalam keadaan istirahat rata-rata $4 \mathrm{ml}$ karbondioksida ditranspor dari jaringan ke paru dalam setiap $1.200 \mathrm{ml}$ darah.

\section{PENGARUH LINGKUNGAN PADA PERNAPASAN}

\section{Efek Ketinggian}

Tubuh kita diperlengkapi secara optimal untuk hidup dibawah tekanan atmosfer normal. Ketika kita naik ke puncak genung yang jauh lebih tinggi dari permukaan laut, tekanan atmosfer secara progresif berkurang seiring dengan peningkatan ketinggian. Pada ketinggian 5.400 meter diatas permukaan laut, tekanan atmosfer hanya $380 \mathrm{mmHg}$, setengah dari nilai diatas permukaan laut. Oleh karena proporsi 02 dan N2 dalam udara tidak berubah, PO2 udara inspirasi alveolus lebih rendah yaitu $45 \mathrm{mmHg}$. Setiap ketinggian 3000 meter PO2 arteri turun dibawah rentang aman.

Orang naik ke ketinggian 3000 meter secara cepat akan mengalami akut mountain sickness yang mengakibatkan hipoksia hipoksik dan alkalosis hipoksik, alkalosis yang diinduksi oleh hipokapmia. Peningkatan dorongan ventilasi bernapas untuk memperoleh tambahan $\mathrm{O} 2$ menyebabkan alkalosis respiratorik karena $\mathrm{CO} 2$ membentuk asam lebih banyak yang dikeluarakan daripada yag diproduksi. Gejala "penyakit gunung" ini adalah rasa lelah, mual,nafsu makan hilang, bernapas terengah-engah, kecepatan denyut jantung meningkat dipicu oleh hipoksia. Disfungsi saraf ditandai dengan gangguan penilaian, pusing dan inkoordinasi.

Jika seorang tetap berada diketinggian, respons kompensasi akut berupa peningkatan ventilasi dan curah jantung akan bertahap. Selama bebarapa hari akan diganti oleh upaya kompensasi yang berkembang lebih lambat yang memungkinkan oksigenasi jaringan adekuat dan pemulihan keseimbangan asam basa.

Peningkatan kapasitas darah mengangkut $\mathrm{O} 2$ memmudahkan $\mathrm{O} 2$ dibebaskan dari $\mathrm{Hb}$ di jaringan. Jumlah kapiler dalam jaringan meningkat sehingga jarak yang harus di tempuh 
oksigen lebih pendek. Sel mengalami aklimatisasi penyesuaian dengan iklim) sehingga mampu menggunakan $\mathrm{O} 2$ secara lebih efisien. Ginjal memulihkan $\mathrm{pH}$ ke tingkat normal dengan menahan asam yang dalam keadaan normal dikeluarkan melalui urine, akibatnya jantung bekerja keras untuk memompa darah melintasi pembuluh darah.

\section{Efek Menyediakan}

Ketika seorang menyelam ke laut dalam, tubuh terpajan pada tekanan yang lebih besar daripada tekanan atmosfer. Tekanan dengan cepat meningkat sesuai dengan kedalaman laut akibat berat air. Udara yang disediakan oleh peralatan untuk bernapas dalam air di salurkan ke paru dengan tekanan tinggi. Udara terdiri dari $70 \%$ nitrogen yang kurang larut dalam jaringan tubuh. PN2 yang tinggi terjadi selama menyelam di laut dalam menyebabkan lebih banyak N2 yang larut dalam jaringan tubuh. Semakin banyak N2 yang larut saat menyelam timbul nekrosis (pembiusan nitrogen) atau rasa gembira di kedalaman. Nekrosis nitrogen di perkirakan terjadi karena penurunan eksitabilitas akibat adanya N2 yang larut di membran lemak pada sel tersebut.

Pada kedalam 45 meter dibawah permukaan laut, penyelam mengalami perasaan euforia (perasaan gembira) dan mengantuk. Di kedalaman 105-120 meter penyelam menjadi lemah, canggung, dan kehilangan kesaradan. Toksisitas oksigen akibata tingginya PO2 merupakan efek lain yang merugikan. Jika seorang penyelam cukup lama di bawah permukaan laut, sejumlah N2 secara bermakna terlarut dalam jaringan. Bila secara tiba-tiba naik dengan cepat keluar dari larutan dan membentuk gelembung-gelembung gas N2 ditubuh. Keadaan ini disebut penyakit dekompresi (pembengkokan) dengan naik secara pelan-pelan ke permukaan sehingga kelebihan N2 dapat secara perlahan keluar melalui paru tanpa membentuk gelembung. 
Sistem Persarafan atau Nervous System terdiri dua bagian utama, yaitu Sistem Saraf Pusat (SSP) (Central Nervous System (CNS)) dan Sistem Saraf Perifer (Peripheral Nervous System (PNS)). Sistem saraf pusat meliputi otak dan sumsum tulang belakang (spinal cord), sedangkan yang termasuk kedalam sistem saraf perifer adalah saraf kranial, saraf spinal, dan sistem saraf otonom (Daniels \& Nicoll, 2012; Smeltzer, Hinkle, Bare, \& Cheever, 2010; Timby \& Smith, 2010; Tortora \& Derrickson, 2014).

Secara umum fungsi dari sistem saraf adalah sebagai kontrol dari motoric, sensorik, otonom, kognitif dan aktifitas perilaku (Smeltzer et al., 2010). Klein \& Stewart-Amidei, 2009 mengatakan otak itu sendiri mengandung lebih dari 100 miliar sel yang menghubungkan jalur mortorik dan sensork, memonitor seluruh proses tubuh, merespon lingkungan eksternal maupun internal, mempertahankan homeostasis, dan mengatur semua psikologis, biologis serta aktivitas fisik melalui reaksi kimia maupun listrik secara kompleks (Smeltzer et al., 2010). Otak dengan massa hanya $2 \mathrm{~kg}$, sekitar $3 \%$ dari total berat badan, Merupakan sistem yang terkecil dan paling komplek dari 11 sistem tubuh (Tortora \& Derrickson, 2014).

Seluruh sistem saraf terdiri dari dua jenis sel yaitu neuron yang mengirim atau menghantarkan impuls saraf, dan sel-sel neuroglial yang mensupport dari neuron (Daniels \& Nicoll, 2012). Neuron dapat berupa sensorik maupun motoric, neuron sensorik mengirimkan impuls ke CNS, Neuron motoric mengirimkan impuls dari CNS (Timby \& Smith, 2010). Hal tersebut tersebut sebagai pengantar dan berikut akan dibahas anatomi dan fisiologi lebih detail dari sistem persarafan.

\section{Cel Sistem Saraf}

Jaringan saraf terdiri dari 2 jenis sel yaitu neuron dan neuroglia. Sel-sel ini bergabung dalam beragam variasi di berbagai daerah sistem saraf. Sebagian besar fungsi dari sistem saraf berasal dari neuron, seperti pengindraan, berfikir, mengingat, mengendalikan aktivitas otot, dan mengatur sekresi kelenjar. Akibat dari semua itu, kebanyakan neuron kehilangan kemampuan untuk melakukan mitosis. Neuroglia adalah sel yang lebih kecil dan jumlahnya melebihi jumlah neuron, kemungkinan 25 kali neuron. Fungsi neuroglia yaitu memelihara dan melindungi neuron serta menjada cairan interstitial. Tidak seperti neuron, neuroglia terus melakukan mitosis sepanjang hidup. Baik neuron dan neuroglia berbeda secara strukturnya, bergantung apakah berada di Sistem Saraf Pusat atau Sistem Saraf Perifer. Perbedaan-perbedaan dalam struktur mempunyai korelasi dengan perbedaan fungsi sistem saraf pusat dan sistem saraf perifer.

a. Neuron

Seperti sel-sel otot, neuron (sel saraf) memiliki rangsangan listrik, kemampuan untuk merespon rangsangan dan mengubahnya menjadi pontensial aksi. Pontensial aksi tersebut dimulai dari suatu stimulus yang kuat dari lingkungan yang mengalami perubahan. Potensial aksi (impuls saraf) merupakan sinyal listrik yang menyebar sepanjang permukaan membrane neuron. Hal tersebut terjadi karena gerakan ion (seperti natrium dan kalium) antara cairan interstitial dengan bagian dalam neuron melalui saluran ion tertentu di membrane plasma.

Ketika potensial aksi terjadi, impuls saraf berjalan dengan cepat dan pada kekuatan yang stabil. Beberapa neuron yang kecil menyebarkan impuls melalui jarak yang pendek (kurang dari $1 \mathrm{~mm}$ ) dalam CNS. Sedangkan yang lain neuron yang panjang 
berada dalam tubuh. Neuron yang memungkinkan anda menggoyangkan jari-jari kaki anda. Beberapa neuron yang lebih panjang lagi, memungkinkan anda merasakan bulu yang menggelitik jari-jari anda. Impuls saraf yang tersebut berjalan jauh dengan kecepatanberkisar 0,5-130 meter per-detik (1-290 mil/jam).

1) Bagian-bagian Neuron

Neuron memiliki 3 bagian yaitu (1) badan sel, (2) dendrit, dan (3) akson (lihat gambar). Dalam sel tubuh, yang juga dikenal sebagai perikaryon atau soma, memiliki inti yang dikelilingi oleh sitoplasma dan juga termasuk didalamnya organel seluler yang khas seperti lisosom, mitokondria, dan kompleks golgi. Badan sel juga mengandung ribosom bebas dan kelompok yang menonjol kasar di reticulum endoplasma, disebut dengan badan Nissl. Ribosom merupakan lokasi sistesis protein. Protein disintesis dan diproduksi oleh badan Nissl, yang digunakan untuk mengganti komponen sel, sebagai bahan untuk pertumbuhan neuron, dan untuk menumbuhkan akson di PNS. Cytoskeleton termasuk dalam neurofibril, berfungsi membentuk dan memberikan support sel. Dan microtubules yang membantu dalam pergerakan material antara badan sel dan akson. Penuaan neuron mengandung lipofuscin, suatu pigmen yang terjadi akibat gumpalan granul dalam sitoplasma yang berwarna coklat kekuningan. Lipofuscin merupakan produk dari lisosom yang terakumulasi sehubungan usia neuron, akan tetapi tidak membahayakan neuron. 


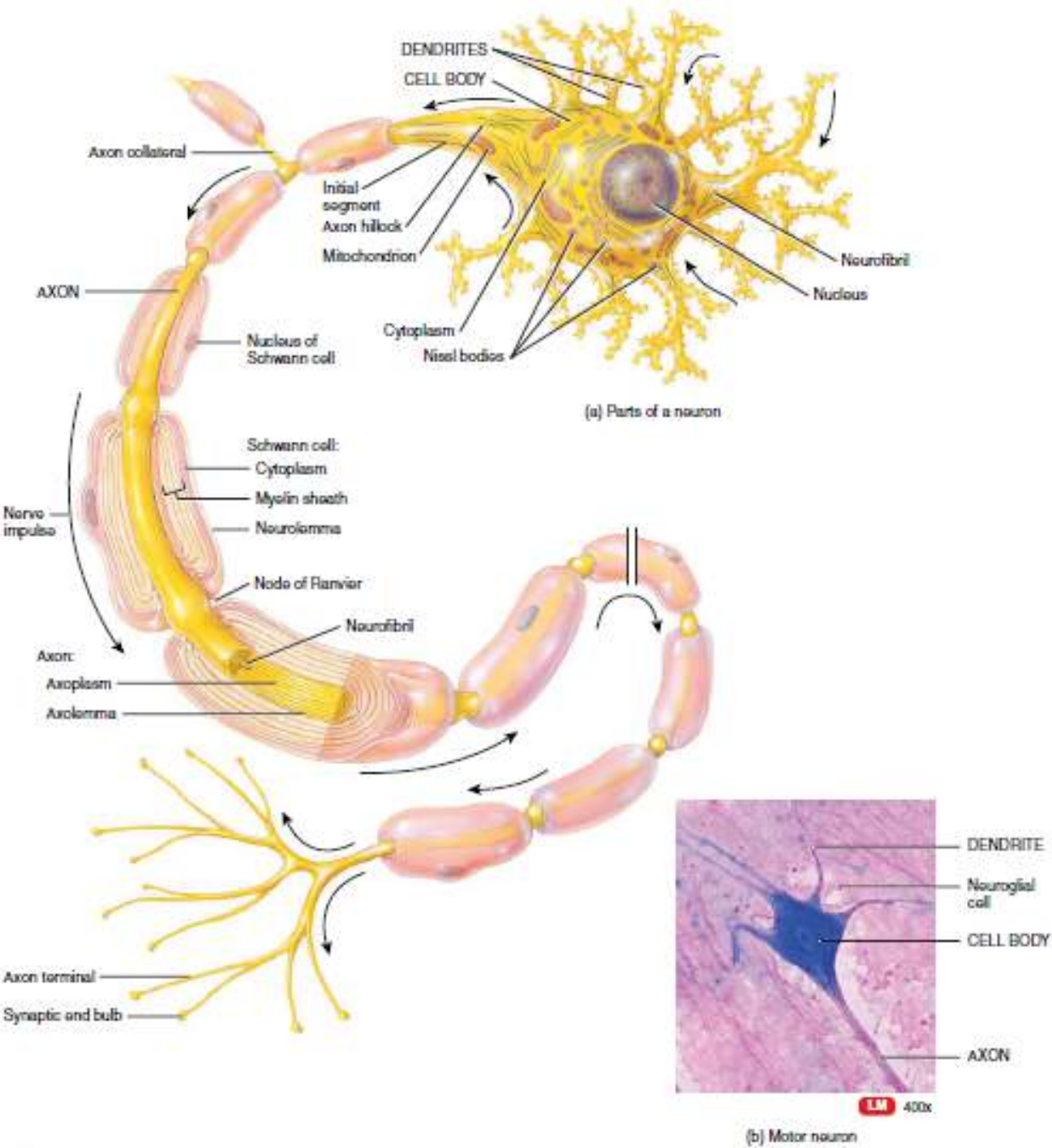

Kebanyakan neuron memiliki dua jenis yaitu multiple dendrit dan satu akson, dendrit yang menerima atau bagian imput neuron. Membrane plasma dendrit mengandung banyak reseptor untuk mengikat pembawa pesan kimia dari selsel lain. Dendrit biasanya pendek, lonjong, dan bercabang. Dalam berbagai neuron, dendrit membentuk array yang berbentuk seperti pohon, membentang dari badan sel. Sitoplasmanya mengandung badan Nissl, mitokondria, dan organl lainnya.

Suatu akson dari neuron menjalan sebagai impuls saraf yang menuju neuron lain, serabut otot, atau sel kelenjar. Akson memiliki badan panjang, tipis dan berbentuk silinder yang bergabung dengan sel tubuh pada puncaknya berbentuk kerucut yang disebut bukit (hillock) akson. Bagian ari akson yang terdekat dengan bukit akson disebut dengan initial segmen. Dalam kebanyakan neuron, impuls saraf yang muncul dari pertemuan antara bukit akson dan initial segmen, suatu daerah yang disebut sebagai zona pemicu. Akson mengandung mitokondria, mikrotubulus, dan neurofibril. Karena didalam akson tidak terdapat reticulum endoplasma, maka tidak ada sistesis protein dalam akson. Sitoplasma dalam akson disebut axoplasm, yang dimana dikelilingi oleh membrane plasma yang dikenal sebagai axolemma. Sepanjang akson terdapat 
cabang disebut sebagai akson collateral, yang dapat bercabang, biasanya disudut kanan akson. Akson dan akson collateral berakhir dengan membagi banyak bagian yang disebut dengan terminal akson atau akson telodendria.

Tempat terjadinya komunikasi antar dua neuron atau antara neuron dan sel efektor disebut dengan Sinaps. Dari sejumlah terminal akson yang mengembang berbentuk menyerupai bola disebut dengan bulbs dan sinaptik, yang lain disebut varicosities. Baik dari bulbs, sinaptik maupun varicosities mengandung banyak kantung membrane yang kecil dan tertutup disebut vesikel sinaptik, vesikel sinaptik tersebut menyimpan bahan kimia yang disebut neurotransmitter. neurotransmitter merupakan molekut yang dilepaskan visikel sinaptik yang merangsang ataupun menghambat proses di neuron, serabut otot atau sel kelenjar. Banyak neuron yang terdiri dari dua atau bahkan tiga jenis neurotransmitter, masing-masing dengan yang berbeda pada sel postsinaptik.

2) Keanekaragaman Struktur Neuron

Neuron mempunyai keanekaragaman baik ukuran dan bentuk. Sebagai contoh, badan sel neuron berdiameter berkisar dari 5 micrometer (sedikit lebih kecil dari sel darah merah) sampai dengan 135 micrometer (nyaris tidak terlihat dengan mata telanjang). Pola dendrit merupakan pencabangan, setiap neuron memiliki pola dendrit yang bervariasi dan khas sesuai bagian dalam sistem saraf.

3) Klasifikasi Neuron

Neuron diklasifikasikan menurut jumlah struktur yang membentang dari badan sel.

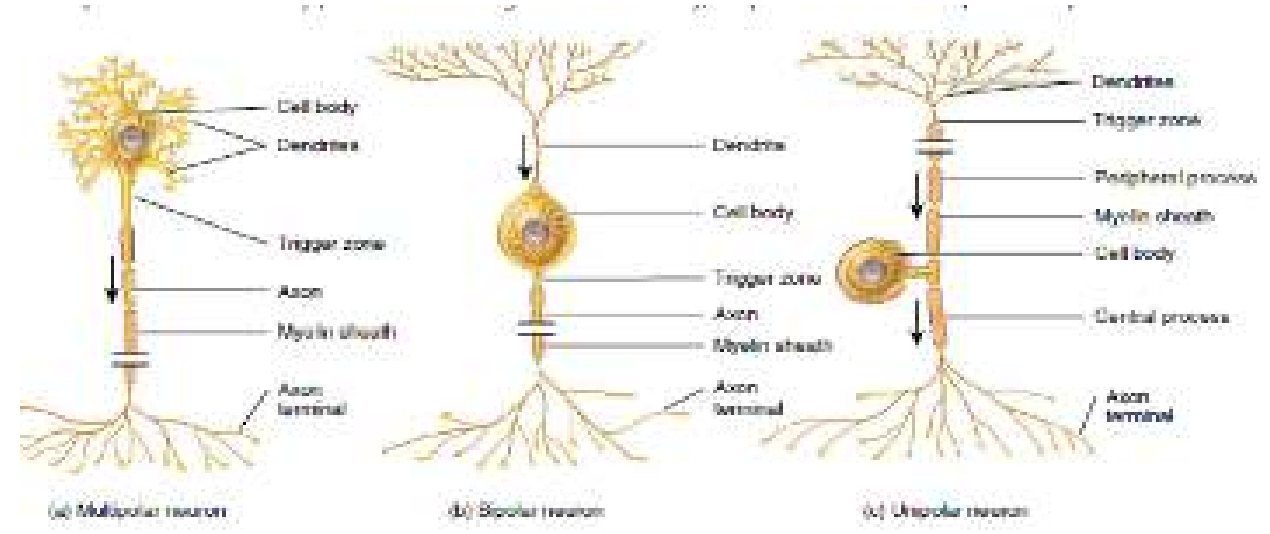

a) Neuron Multipolar

Neuron multipolar biasanya memiliki sejumlah dendrit dan satu akson. Kebanyakan neuron multipolar terdapat di otak dan sumsum tulang belakang, serta seluruh saraf motorik.

b) Neuron Bipolar

Neuron bipolar memiliki satu dendrit dan satu akson. Neuron bipolar ini terdapat pada retina mata, bagian dalam telinga, dan daerah penciuman.

c) Neuron Unipolar

Neuron unipolar memiliki dendrit dan akson menjadi satu yang digabungkan untuk membentuk proses yang berkesinambungan yang muncul dari badan sel. Neuron ini lebih tepat disebut sebagai neuron psedounipolar, karena 
berembrio sebagai bipolar neuron. Dalam perkembangannya, dendrit dan akson bersama-sama dan menjadi proses tunggal. Dendrit dari neuron unipolar yang berfungsi sebagai reseptor sensorik, bertugas mendeteksi stimulus sensori seperti sentuhan, tekanan, rasa sakit, atau rangsangan termal. Pada zona pemicu sebagai persimpangan antara dendrit dan akson. Sel neuron unipolar kebanyakan terletak di ganglia dari tulang belakang dan saraf cranial.

Disamping skema diatas, beberapa neuron dinamai secara histologist yang menggambarkan dari bentuk neuron, yaitu sel purkinje di otak kecil dan sel piramida ditemukan dicorteks cerebral.

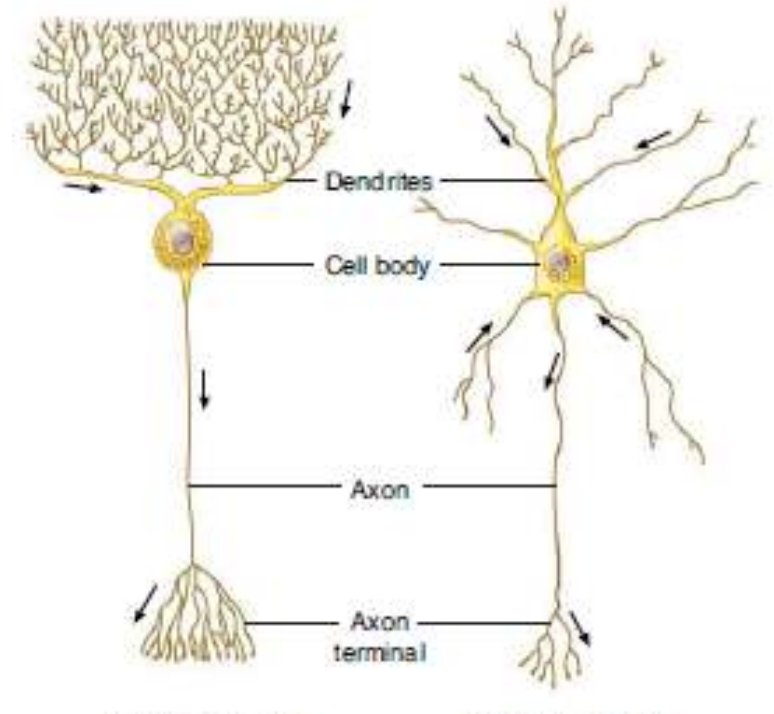

$\begin{array}{ll}\text { (a) Purkinje cell } & \text { (b) Pyramidal cell }\end{array}$

Secara fungsional, neuron diklasifikasikan sesuai dengan arah dimana impuls saraf (potensial aksi) tersebut disampaikan ke CNS.

a) Sensory atau saraf afferent mengandung reseptor di ujung distal dendrit atau terletak setelahnya sehingga merupakan sel tersendiri. Setelah terdapat stimulus yang mengaktifkan reseptor sensori, neuron sensori terjadi potensial aksi tepatnya di akson, dan potensial aksi tersebut disampaikan ke CNS melalui saraf cranial atau tulang belakang. Kebanyakan neuron sensorik dalam strukturnya berbentuk unipolar.

b) Motorik atau saraf efferent menyampaikan potensial aksi dari CNS ke efektor (otot dan kelenjar) pada perifer (PNS) melalui saraf kranial atau tulang belakang. Neuron motoric dalam strukturnya berbentuk multipolar.

c) Interneuron atau saraf assosiasi berlokasi di CNS tepatnya diantara neuron sensorik dan motoric. Interneuron mengintegrasikan (proses) informasi yang masuk dari sensorik dan kemudian menimbulkan respon motoric dengan mengaktifkan neuron motoric yang sesuai. Kebanyakan interneuron berstruktue multipolar. 


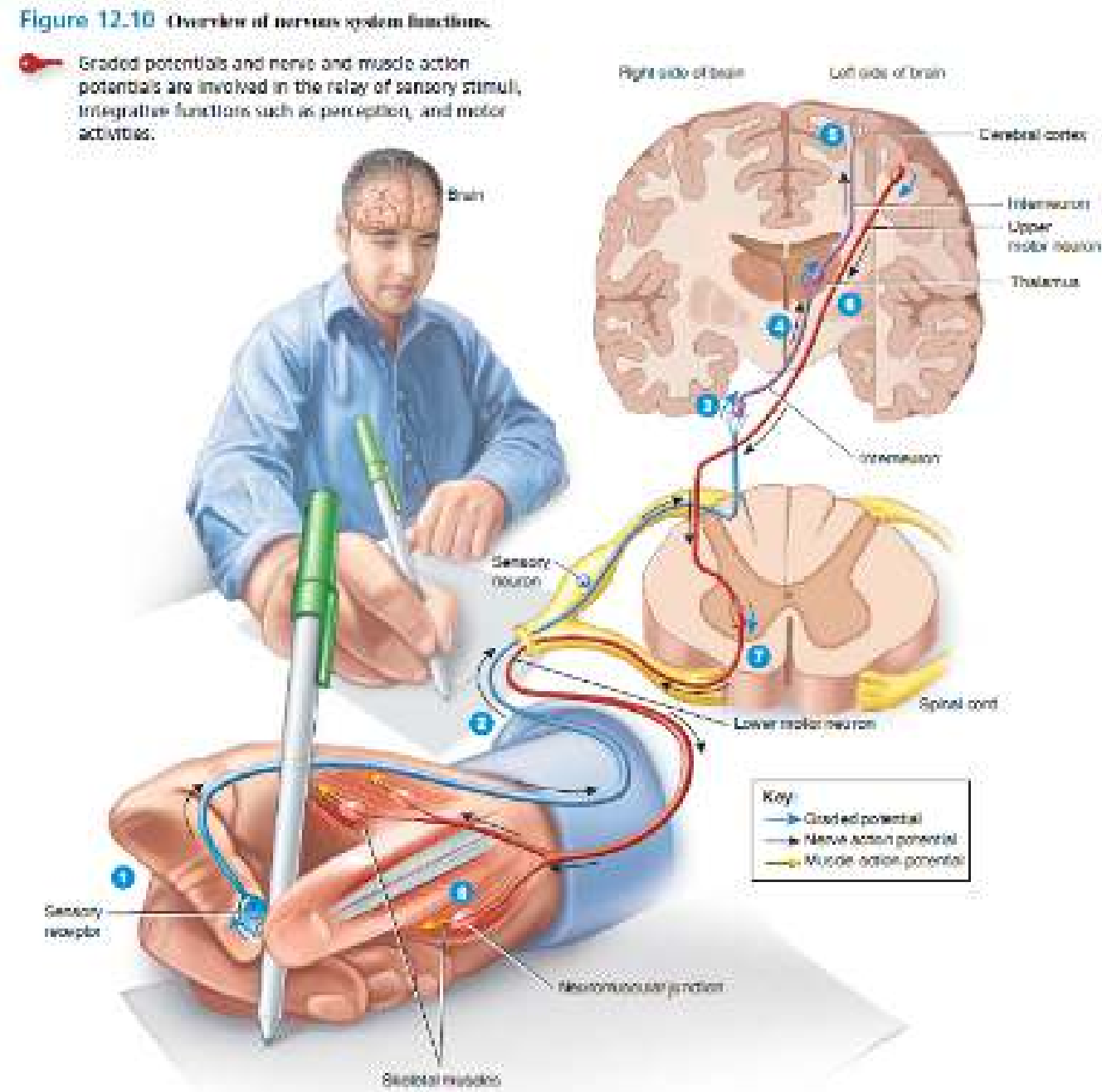

b. Neuroglia

Neuroglia atau glia mencangkup sekitar setengah dari volume CNS. Nama glia berasal dari ide histologis awal bahwa glia adalah "glue" diterjemahkan dalam bahasa Indonesia perekat, neuroglia tidak hanya berperan pasif melainkan aktif dalam kegiatan sistem saraf. Umumnya neuroglia lebih kecil dari neuron, dan 5-25 kali lebih banyak dari pada neuron. Berbeda dengan neuron, glia tidak menghasilkan atau menyebarkan potensial aksi, dan glia dapat berkembang biak atau melakukan mitosis. Dalam kasus cedera kepala atau penyakit, neuroglia memperbanyak untuk mengisi ruang yang sebelumnya ditempati oleh neuron. Tumor otak yang berasal dari glia, yang disebut glioma cenderung bersifat sangat ganas dan berkembang pesat. Dari enam jenis neuroglia, empat diantaranya ditemukan di CNS yaitu astrosit, oligodendrocytes, mikroglia, dan ependymal. Dua diantaranya di PNS yaitu sel schwann dan sel satellite.

1) Neuroglia CNS

Neuroglia CNS diklasifikasikan berdasarkan ukuran, proses sitoplasma dan kelompok intraseluler menjadi empat jenis yaitu astrosit, oligodendrocytes, sel mikroglia, dan sel-sel ependymal. 


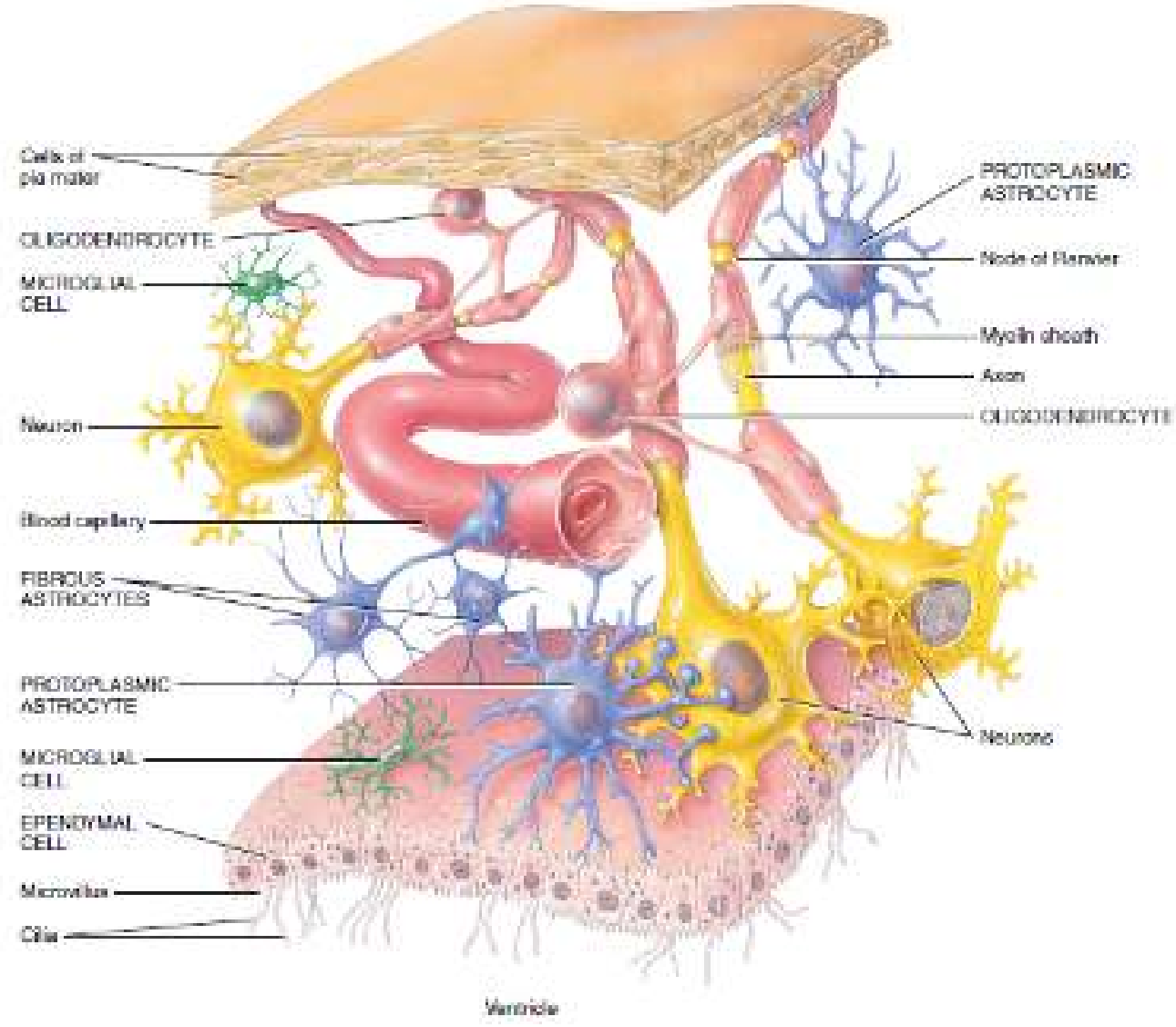

a) Astrosit

Sel yang bentuk bintang memiliki banyak proses dan merupakan sel terbesar serta paling banyak diantara sel neuroglia. Ada dua jenis astrosit yaitu astrosit protoplasma memiliki percabangan pendek dan ditemukan di gray matter, selanjutnya astrosit fibrosa memiliki cabang yang lebih panjang dan terletak terutama white matter. Astrosit berfungsi sebagai penghubung kapiler darah, neuron, dan piameter.

b) Oligodendrocytes

Menyerupai astrosit tetapi lebih kecil dan lebih sedikit, oligodendrocytes bertanggungjawab untuk membentuk dan mempertahankan selubung myelin di sekitar akson CNS. Selubung myelin merupakan lipid dan protein yang berlapis disekitar akson. Myelin meningkatkan kecepatan konduksi impuls saraf.

c) Mikroglia

Neuroglia ini merupakan sel yang kecil dengan bentuk ramping yang mengeluarkan banyak spinelike. Sel mikroglia atau fungsi mikroglia sebagai fagosit. Seperti makrofag jaringan, mereka menghilangkan kotoran selular terbentuk selama perkembangan normal dari sistem saraf dan memfagositosis mikroba dan jaringan saraf yang rusak.

d) sel-sel ependymal

Sel ependymal merupakan cuboidal sel kolumnar berada dalam satu lapisan yang memiliki mikrovili dan silia. Sel ini melapisi ventrikel otak dan saluran tulang belakang (ruang penuh dengan cairan cerebrospinal, yang melindungi 
dan memelihara otak dan sumsum tulang belakang). Secara fungsional, ependymal memproduksi sel, memonitor, dan membantu dalam sirkulasi cairan cerebrospinal. Sel ependymal juga mengatur darah dan cairan cerebrospinal.

2) Neuroglia PNS

Neuroglia dari PNS sepenuhnya mengelilingi akson dan badan sel. Dua jenis sel glial di PNS merupakan sel Schwann dan Sel-sel satelit.

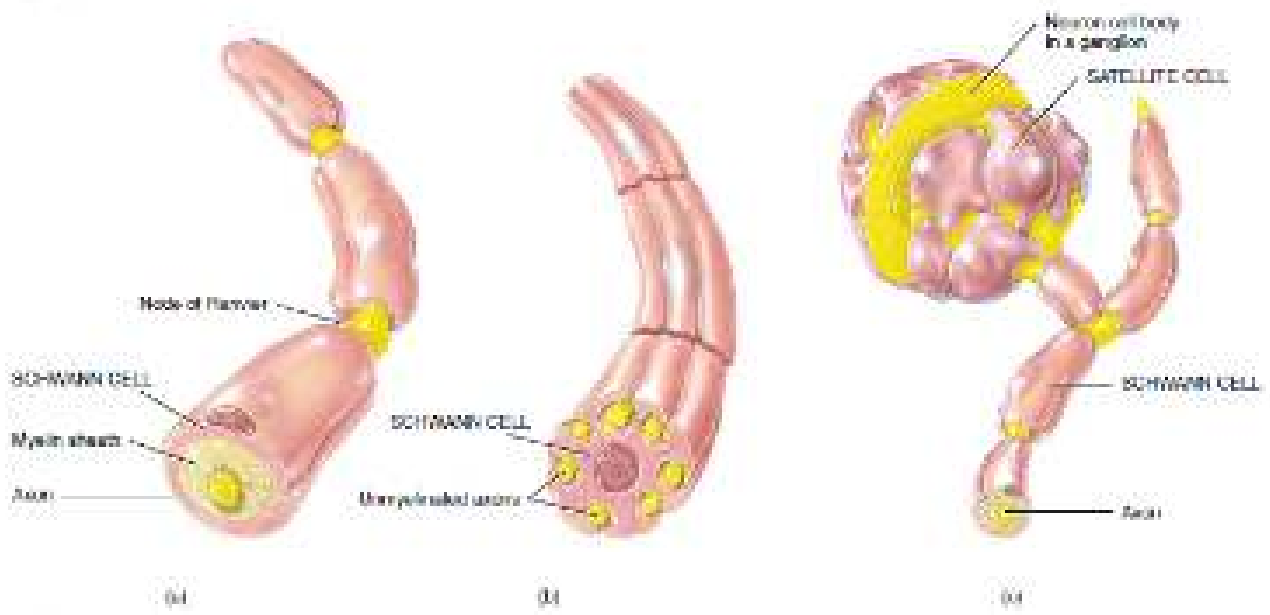

a) Sel Schwann

Sel-sel ini mengelilingi akson PNS. Seperti oligodendrocytes, mereka membentuk selubung myelin di sekitar akson. Sebuah oligodendrocyte tunggal myelinates beberapa akson, tetapi setiap sel Schwann myelinates akson tunggal. Sebuah sel Schwann tunggal juga dapat menyertakan sebanyak 20 atau lebih atau akson unmyelinated (akson yang tidak memiliki selubung mielin). Sel Schwann berpartisipasi dalam regenerasi akson, yang lebih mudah dilakukan di PNS daripada di CNS.

b) Sel-sel satelit

Sel-sel pipih mengelilingi badan sel neuron dari ganglia PNS. Selain memberikan dukungan struktural, sel-sel satelit mengatur pertukaran material di antara badan sel saraf dan cairan interstitial.

c. Myelin

Akson yang dilapisi oleh lipit dan protein yang berlapis-lapis disebut myelin. Selubung elektrik menyekat akson dari neuron dan meningkatkan kecepatan konduksi impuls saraf. Akson tanpa penutup dikatakan unmyelinated. 


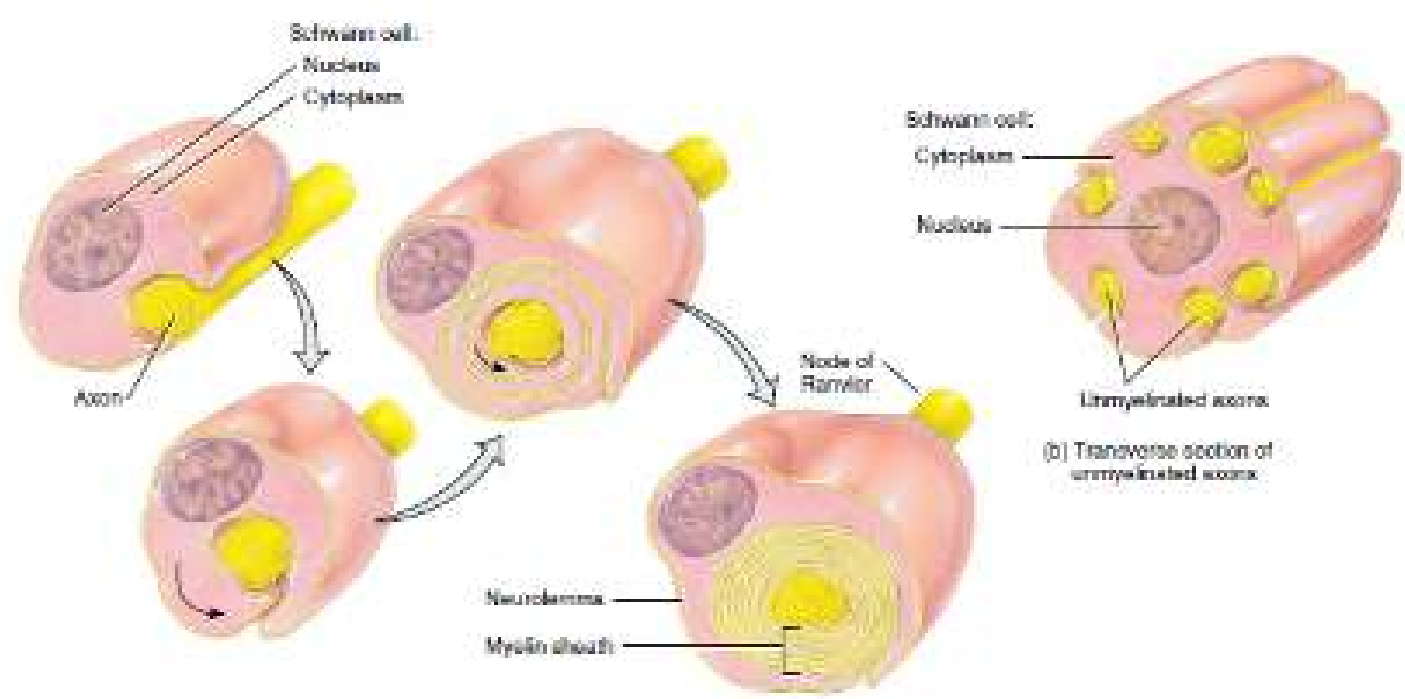

Dua jenis neuroglia menghasilkan selubung myelin, sel schwan (PNS) dan oligodendrocyte (CNS). Sel schwan mulai terbentuk selubung myelin selama perkembangan dalam janin. Setiap Sel schwan melapisi sekitar 1 milimeter membentuk spiral sepanjang akson. Sebuah Selubung Mielin hanya ditemukan sekitar akson di PNS. Ketika akson terluka, Selubung Mielin bantu regenerasi dengan membentuk tabung regenerasi yang memandu dan merangsang pertumbuhan kembali akson. Kesenjangan dalam selubung myelin, yang disebut simpul Ranvier, muncul dengan interval sepanjang akson. Setiap sel Schwann membungkus satu segmen akson antara dua nodus.

Di CNS, oligodendrocyte melapisi bagian dari beberapa akson. Setiap oligodendrocyte sebagiannya bertempat sekitar 15 luas akson, berbentuk pipih dan spiral sekitar akson CNS, membentuk selubung myelin. Simpul Ranvier jumlahnya lebih sedikit. Akson di CNS mengalami pertumbuhan kembali yang kecil setelah cedera. Hal ini diduga, kaitannya dengan Selubung Mielin, dan sebagian pengaruh penghambatan diberikan oleh oligodendrocytes pada pertumbuhan akson.

d. Gray dan White Matter

Beberapa daerah di otak dan disumsum tulang belakang tampak terlihat putih dan yang lain tampak keabu-abuan. White matter terdiri dari akson yang bermielin. Warna putih dari myelin. Gray matter dari sistem saraf mengandung badan sel saraf, dendrit, akson yang tidak bermielin, terminal akson, dan neuroglia. Tampak keabuabuan karena badan Nissl memberi warna abu-abu dan sedikit myelin. Ditulang belakang, white matter mengelilingi gray matter yang berbentuk seperti kupu-kupu atau huruf $\mathrm{H}$ pada bagian yang melintang. Di otak gray matter menutupi permukaan bagian besar otak cerebrum dan cerebellum. 


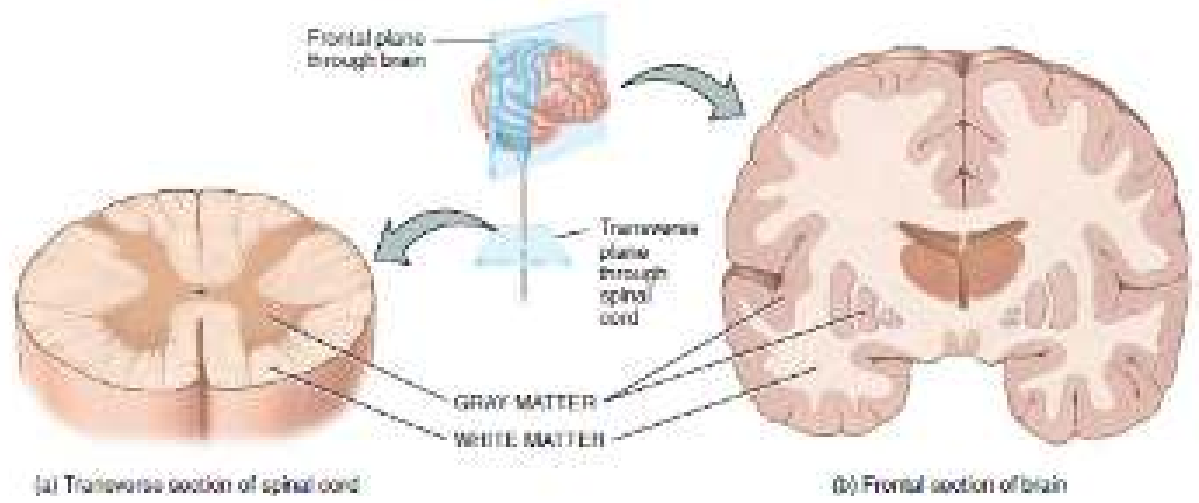

\section{Fungsi Sistem Saraf}

Sistem saraf mempunyai fungsi yang begitu kompleks. Hal ini dapat kita rasakan berbagai bau, menghasilkan ucapan dan mengingat peristiwa masa lalu. Disamping itu, sistem saraf juga memberikan sinyal yang mengontrol gerakan tubuh dan mengatur operasional organ-organ internal. Berbagai kegiatan sistem saraf ini dapat dikelompokan menjadi 3 fungsi dasar, yaitu: sensori (input), integrative (proses), dan motoric (output) (Tortora \& Derrickson, 2014).

a. Fungsi sensorik, Reseptor sensorik mendeteksi stimulus internal, seperti peningkatan tekanan darah, atau rangsangan eksternal misalnya air hujan yang menetes di lengan kita. Informasi sensorik ini dibawa ke otak dan sumsum tulang belakan melalui saraf kranial dan tulang belakang.

b. Fungsi integratif, Sistem saraf sensori memproses informasi dengan mengalisis dan membuat keputusan yang tepat untuk tanggapan, kegiatan ini yang dikenal sebagai integrasi.

c. Fungsi motorik, Setelah informasi sensorik terintegrasi, sistem saraf menghasilkan respon motor yang sesuai, dengan cara mengaktifkan efektor (otot dan kelenjar) melalui saraf kranial dan tulang belakang. Rangsangan dari efektor ini menyebabkan kontraksi otot dan sekresi dari kelenjar.

\section{Sistem Saraf Pusat (SSP) atau Central Nervous System (CNS)}

CNS memiliki dua divisi utama: otak dan sumsum tulang belakang. Otak terdiri dari cerebrum, batang otak, dan cerebellum. Sumsum tulang belakang adalah saluran untuk ascending sensorik dan descending neuron motor. Ini adalah jalur komunikasi dua arah antara otak dan perifer. Selain itu, sumsum tulang belakang adalah pusat untuk aksi refleks.

a. Otak

Hickey (2009) mengatakan Otak mencakup sekitar 2\% dari total berat badan; pada orang dewasa muda rata-rata, berat otak sekitar 1400 gram, sedangkan pada orang tua rata-rata, berat otak sekitar 1200 gram (Smeltzer et al., 2010). Otak dibagi menjadi tiga bidang utama: cerebrum, batang otak, dan cerebellum. Otak terdiri dari dua belahan, thalamus, hypothalamus, dan basal ganglia. Batang otak meliputi midbrain, pons, dan medula. Cerebellum terletak di bawah cerebrum dan di belakang batang otak. 

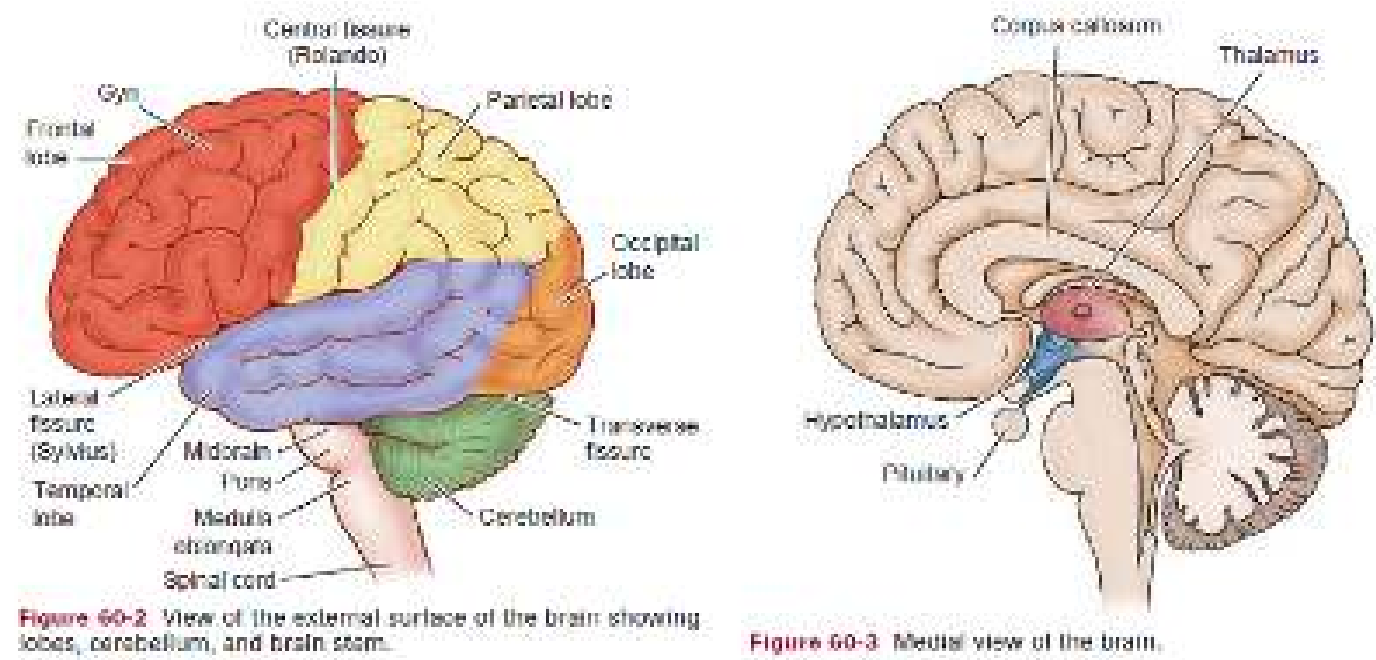

Figure 60-3 Meula visw ol the braill

\section{1) Cerebrum}

Bagian luar permukaan dari belahan otak memiliki penampilan yang kerutan yang merupakan hasil dari banyak lapisan dilipat atau convolutions disebut gyri. dimana berfungsi menambah luas areal permukaan otak, terhitung tingkat yang tinggi aktivitas yang dilakukan oleh organ kecil seperti ini. Di antara masingmasing gyrus merupakan sulkus atau fissure yang berfungsi sebagai pembagian anatomi. Di antara hemisfer otak merupakan fisura yang memanjang memisahkan cerebrum menjadi hemisfer kanan dan kiri. Kedua hemisfer bergabung di bagian bawah fisura oleh corpus callosum. Bagian eksternal maupun bagian luar hemisfer (korteks serebral) yang terdiri dari grey matter sekitar 2 sampai $5 \mathrm{~mm}$ kedalaman; mengandung miliaran sel tubuh neuron, memberikan penampilan yang abu-abu.

White matter membentuk lapisan terdalam dan terdiri dari serabut saraf mielin dan sel-sel neuroglia yang terbentuk saluran atau jalur yang menghubungkan berbagai bagian dari otak dengan satu sama lain. Jalur ini juga menghubungkan korteks dengan bagian-bagian bawah dari otak dan sumsum tulang belakang. Hemisfer serebri dibagi menjadi pasang lobus sebagai berikut: 


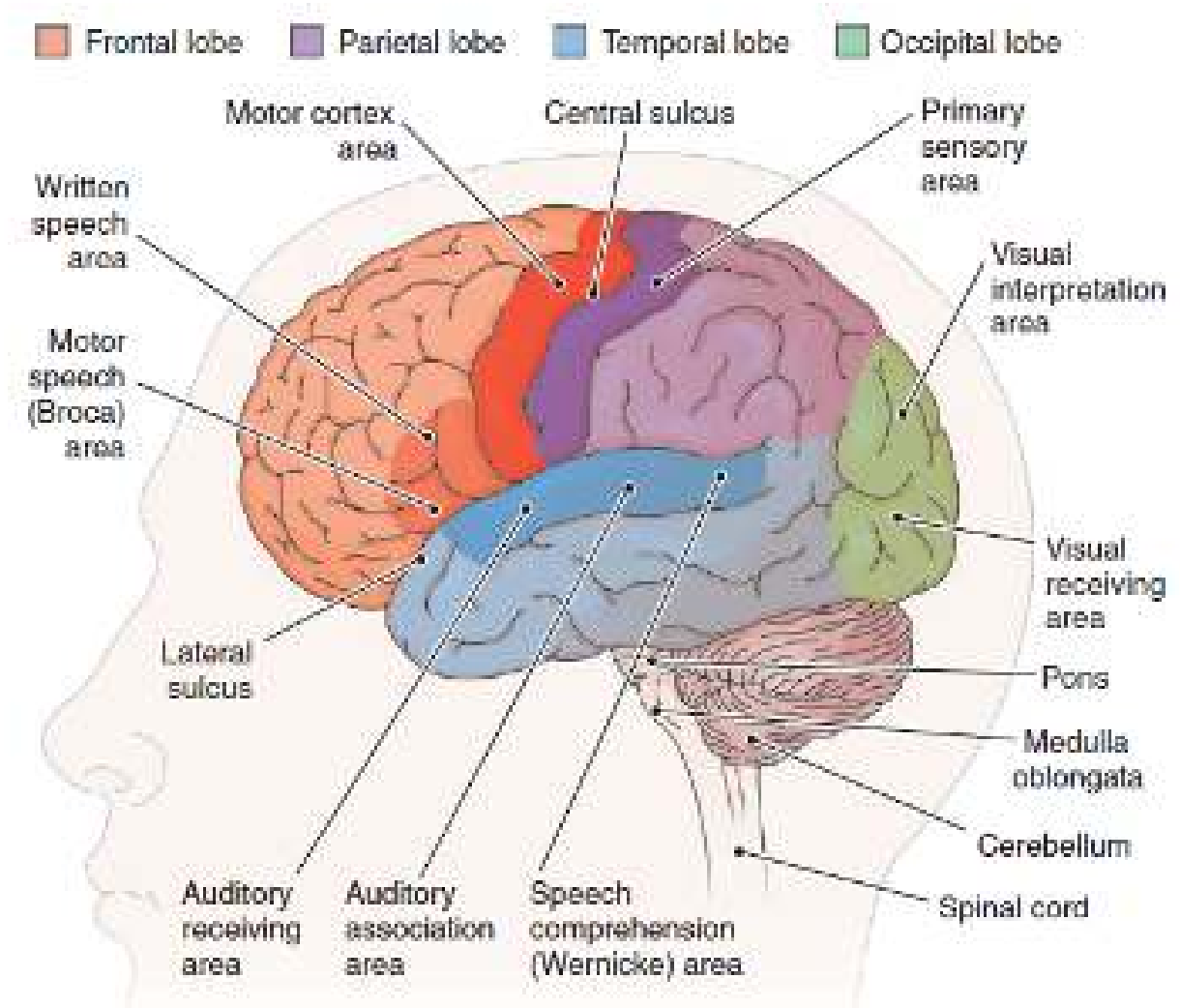

a) Frontal-lobus terbesar, terletak di bagian depan otak. Fungsi utama dari lobus ini adalah konsentrasi, berpikir abstrak, penyimpanan informasi atau memori, dan fungsi motorik. Yang dikandungnya Area Broca, dimana terletak di hemisfer kiri dan sangat penting untuk mengendalikan motor berbicara. Lobus frontal juga bertanggung jawab dalam sebagian besar untuk mempengaruhi keputusan, kepribadian, dan rintangan.

b) Parietal-lobus dibelakang lobus frontal didominasi sensorik. Lobus ini menganalisis informasi sensorik dan merelay interpretasi informasi. dan sangat penting untuk kesadaran seseorang posisi tubuh dalam ruang, ukuran dan bentuk, dan arah kanan-kiri.

c) Temporal-berada lebih rendah daripada lobe frontal dan parietal, lobus hal ini mengandung daerah mudah menerima pendengaran dan memainkan peran dalam memori dan pemahaman tentang bahasa dan musik.

d) oksipital-berada posterior lobus parietal, lobus hal ini bertanggung jawab untuk interpretasi visual dan memori.

Corpus callosum, sekumpulan serabut saraf yang menghubungkan dua belahan otak, bertanggung jawab untuk pengiriman informasi dari satu sisi otak yang lain. Informasi ditransfer meliputi sensasi, memori, dan mempelajari perbedaan. Orang kidal dan beberapa orang kidal memiliki dominasi otak di sisi kiri otak untuk verbal, linguistik, aritmatika, perhitungan, dan fungsi analitik. 


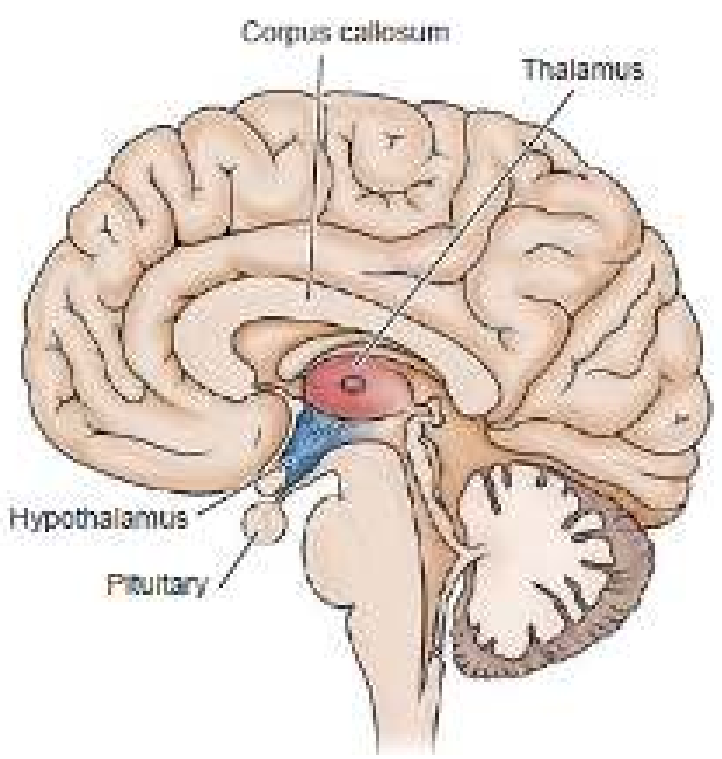

Belahan yang tidak dominan bertanggung jawab atas geometris, tata ruang, visual, pola, dan fungsi musik. Nukleus untuk saraf kranial I dan II juga terletak di cerebrum. Ganglia basal merupakan massa inti terletak jauh di hemisfer serebri yang bertanggung jawab untuk mengontrol gerakan motorik halus, termasuk tangan dan ekstremitas bawah. Thalamus terletak di kedua sisi ventrikel ketiga dan bertindak terutama sebagai stasiun relay untuk semua sensasi kecuali bau. Semua memori, sensasi, dan impuls nyeri melewati bagian otak.

Hipotalamus terletak di anterior dan inferior talamus, dan di bawah dan lateral ventrikel ketiga. Infundibulum hipotalamus menghubungkan ke kelenjar pituitari. Hipotalamus memainkan peran penting dalam sistem endokrin karena mengatur sekresi hipofisis hormon yang mempengaruhi metabolisme, reproduksi, respon stres, dan produksi urine. la bekerja dengan hipofisis untuk menjaga keseimbangan cairan melalui release hormonal dan mempertahankan pengaturan suhu dengan mempertahankan vasokonstriksi atau vasodilatasi. Selain itu, hipotalamus sebagai pusat rasa lapar dan terlibat dalam mengendalikan nafsu makan. pusat yang mengatur siklus tidur-bangun, tekanan darah, perilaku agresif dan seksual, dan tanggapan emosional (misalnya, merona, marah, depresi, panik, dan takut). Hipotalamus juga mengontrol dan mengatur sistem saraf otonom. Kiasma optik (titik di mana dua saluran optik lintas) dan badan mamillary (terlibat dalam refleks penciuman dan respons emosional terhadap bau) juga ditemukan di daerah ini.

\section{2) Batang Otak}

Batang otak terdiri dari midbrain, pons, dan medula oblongata. Midbrain menghubungkan pons dan cerebellum dengan hemisfer otak; mengandung jalur sensorik dan motorik dan berfungsi sebagai pusat refleks pendengaran dan visual. Saraf Cranial III dan IV berasal di midbrain. Pons terletak di depan cerebellum antara midbrain dan medula dan merupakan jembatan antara dua bagian dari cerebellum, dan antara medulla dan midbrain. Saraf kranial $V$ melalui 
VIII berasal dari pons. Pons juga mengandung motorik dan sensorik jalur. Bagian dari pons membantu mengatur respirasi.

Serabut motorik dari otak ke sumsum tulang belakang dan serat sensorik dari sumsum tulang belakang ke otak ini terletak di medula. Sebagian besar serat ini menyeberang, atau decussate. Saraf Cranial IX melalui XII berasal medula. Pusat refleks untuk respirasi, tekanan darah, denyut jantung, batuk, muntah, menelan, dan bersin terletak di medula juga. Formasi reticular, bertanggung jawab untuk gairah dan siklus tidur-bangun, dimulai di medula dan menghubungkan dengan sejumlah struktur lebih besar.

\section{3) Cerebellum}

Cerebellum terletak di posterior midbrain dan pons, dan di bawahnya lobus oksipital. Cerebellum mengintegrasikan informasi sensorik untuk memberikan gerakan yang terkoordinasi. Dia mengontrol baik gerakan, keseimbangan, dan posisi (postural) akal atau proprioception (kesadaran di mana setiap bagian dari tubuh).

\section{b. Sturktur Pelindung Otak}

Otak terdapat dalam tengkorak yang keras, yang melindungi dari cedera. Tulang utama tengkorak adalah frontal, temporal, parietal, oksipital, dan tulang sphenoid. Tulang-tulang ini bergabung di garis suture dan membentuk dasar tengkorak. Lekukan di dasar tengkorak dikenal sebagai fossae. Fossa anterior mengandung lobus frontal, fossa tengah mengandung lobus temporal, dan fossa bagian posterior mengandung cerebellum dan batang otak.

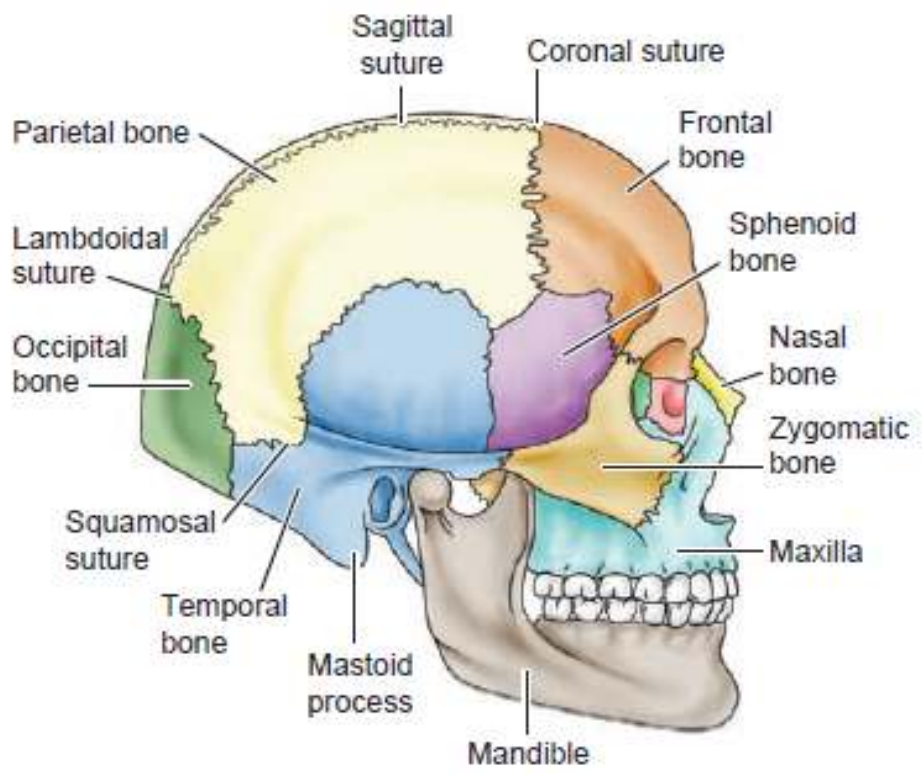

Meninges, jaringan ikat fibrosa yang menutupi otak dan sumsum tulang belakang, memberikan perlindungan, dukungan, dan makanan. Lapisan meninges adalah duramater, arachnoid, dan pia mater. 

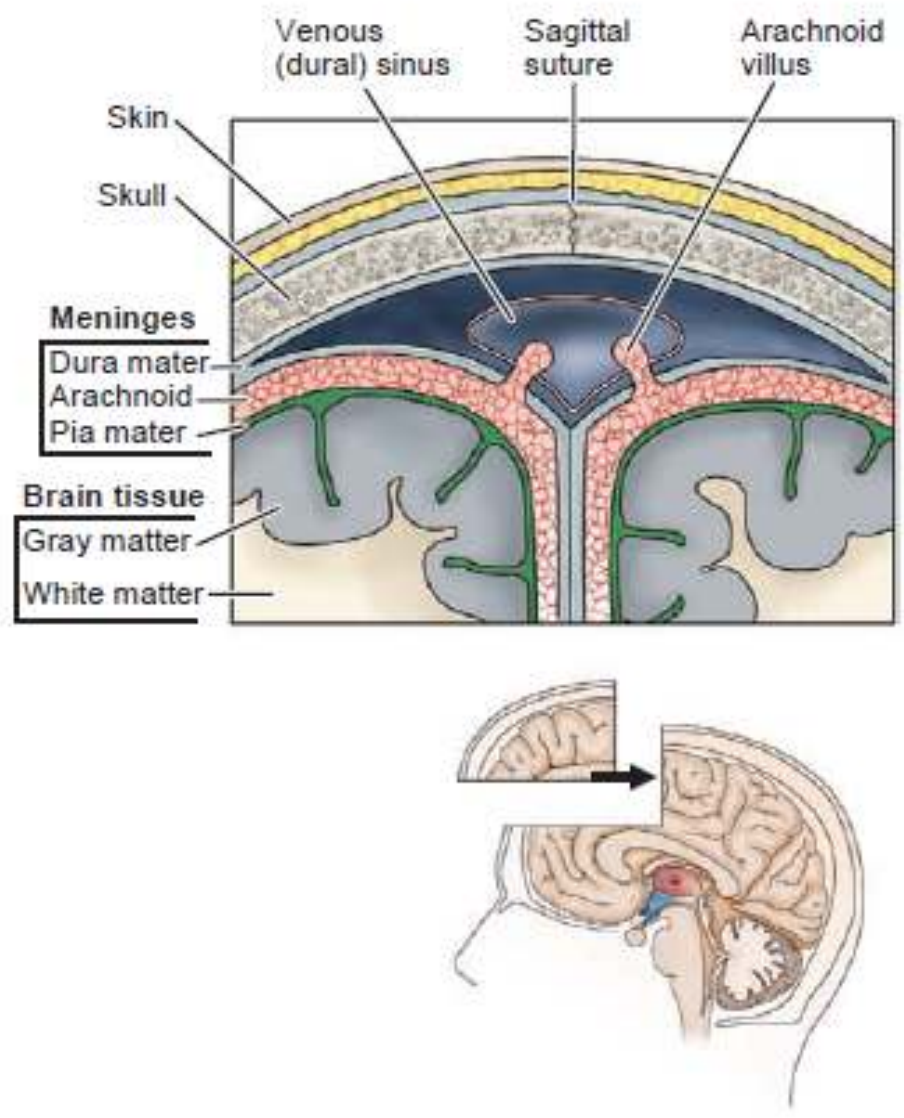

a) Durameter, lapisan terluar; menutupi otak dan sumsum tulang belakang. Lapisan ini sulit, tebal, tidak elastis, berserat, dan abu-abu. Ada tiga jenis utama dura: cerebri falx, yang lipatan antara dua belahan; yang tentorium, lipatan antara lobus oksipital dan cerebellum membentuk suatu lapisan yang keras, shelf membran; dan cerebelli falx, dimana terletak di antara sisi kanan dan kiri dari cerebellum. Ketika tekanan berlebih terjadi pada rongga tengkorak, jaringan otak dapat terkompresi terhadap lipatan dural ini atau berpindah di sekitar mereka atau ke bawah, proses yang disebut herniasi. Sebuah ruang potensial antara dura dan tengkorak, dan antara periosteum dan dura di kolom vertebral, yang dikenal sebagai ruang epidural. Ruang potensial lainnya, ruang subdural, juga ada di bawah dura. Darah atau abses dapat terakumulasi dalam ruang-ruang potensial. 


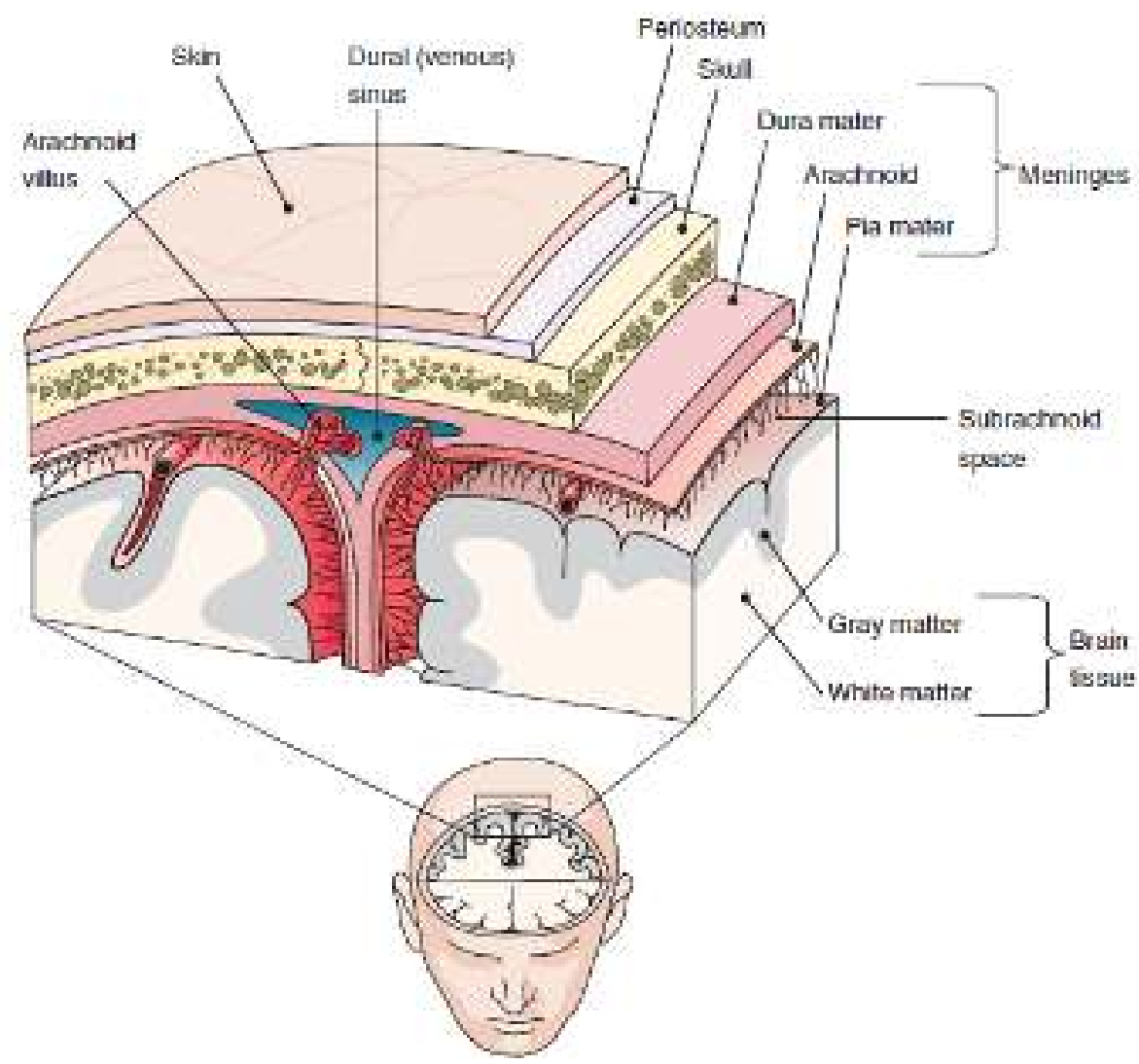

b) Arachnoid, membran tengah; merupakan lapisan yang sangat tipis, membran halus yang mirip jaring laba-laba (maka nama arachnoid). Membran arachnoid memiliki cairan serebrospinal (CSF) dalam ruang di bawahnya, yang disebut ruang subarachnoid. Membran ini memiliki proyeksi fingerlike khusus, yang disebut vili arachnoid, yang menyerap CSF ke dalam sistem vena. Ketika darah atau bakteri masuk ke ruang subarachnoid, vili menjadi terhambat sehingga dapat menyebabkan hidrosefalus (peningkatan ukuran ventrikel) .

c) Piameter lapisan terdalam, tipis, lapisan transparan yang menempel erat dengan otak dan meluas ke setiap lipatan permukaan otak.

\section{c. Cairan Cerebrospinal}

CSF merupakan cairan bening dan tidak berwarna yang diproduksi di pleksus koroid dari ventrikel dan beredar di sekitar permukaan otak dan sumsum tulang belakang. Ada empat ventrikel: kanan dan kiri lateral dan ventrikel ketiga dan keempat. Kedua ventrikel lateral membuka ke dalam ventrikel ketiga di foramen interventrikular atau foramen Monro dari. Ventrikel ketiga dan keempat terhubung melalui saluran air dari Sylvius. Saluran air ventrikel keempat CSF ke dalam ruang subarachnoid pada permukaan otak dan sumsum tulang belakang, di mana ia diserap oleh vili arachnoid. Penyumbatan aliran CSF di mana saja dalam sistem ventrikel berdampak terjadi hidrosefalus obstruktif.

CSF sangat penting dalam fungsi kekebalan tubuh dan metabolisme di otak. la diproduksi pada tingkat sekitar $500 \mathrm{~mL} /$ hari; ventrikel dan ruang subarachnoid mengandung sekitar $150 \mathrm{ml}$ cairan. Komposisi CSF mirip dengan cairan ekstraseluler 
lainnya (seperti plasma darah), tetapi konsentrasi berbagai macam konstituen berbeda. Sebuah analisis laboratorium CSF menunjukkan warna (bening), berat jenis (normal 1,007), jumlah protein, jumlah sel darah putih, gula, dan kadar elektrolit lainnya. CSF juga dapat diuji untuk imunoglobulin atau adanya bakteri. CSF yang normal mengandung jumlah minimal sel darah putih dan tidak ada sel-sel darah merah.

\section{d. Sirkulasi serebral}

Otak tidak akan menyimpan nutrisi dan membutuhkan pasokan konstan oksigen. Kebutuhan ini dipenuhi melalui circirculation serebral; otak menerima sekitar $15 \%$ dari output jantung, atau $750 \mathrm{~mL}$ per menit aliran darah. Sirkulasi otak adalah unik dalam beberapa aspek. Pertama, arteri dan sirkulasi vena tidak sejajar seperti pada organ-organ lain di dalam tubuh; hal ini disebabkan sebagian peran sistem vena bermain di penyerapan CSF. Kedua, otak memiliki sirkulasi kolateral melalui lingkaran Willis, yang memungkinkan aliran darah akan diarahkan sesuai permintaan. Ketiga, pembuluh darah di otak memiliki dua bukan tiga lapisan, dimana dapat membuat mereka lebih rentan pecah saat melemah atau di bawah tekanan.

\section{1) Arteri}

Sumber darah ke otak terjadi melalui arteri karotid internal yang (sirkulasi anterior) dan arteri vertebralis dan basilar (sirkulasi posterior). Arteri ini bergabung di dasar otak untuk membentuk lingkaran Willis (lingkaran arteri serebral). Dua arteri serebral anterior (ACA) menyediakan bagian medial pada lobus frontal. Dua arteri serebral tengah (MCA) memasok bagian luar frontal, parietal, dan lobus temporal superior. Dua arteri serebral posterior rendah (PICA) memasok bagian medial oksipital dan lobus temporal inferior.

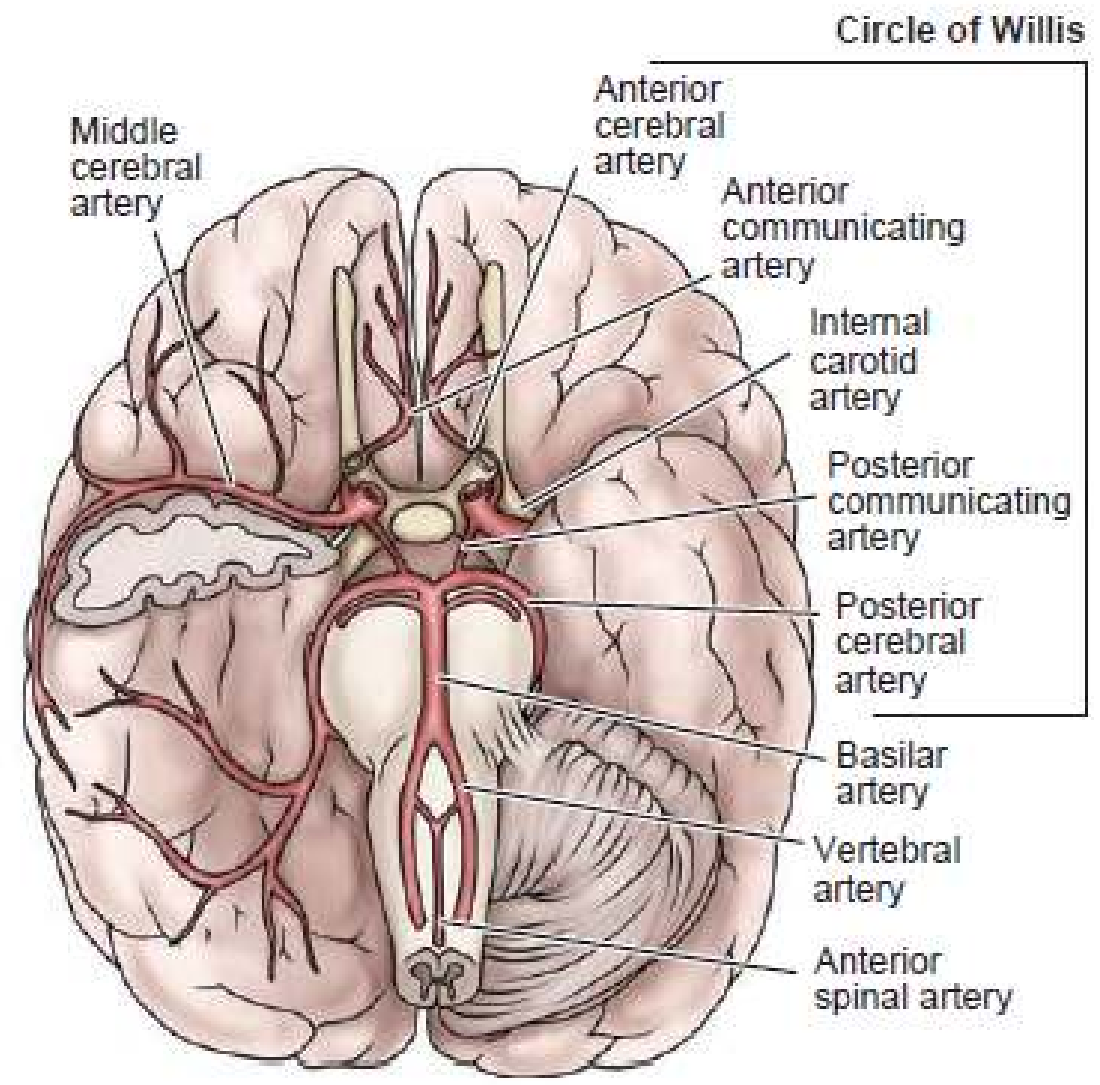


2) Vena Drainase vena untuk otak tidak mengikuti sirkulasi arteri seperti dalam struktur tubuh lainnya. Pembuluh vena mencapai permukaan otak, kemudian menyeberangi ruang subarachnoid ke dalam sinus dural, yang merupakan saluran pembuluh darah dalam dura. Jaringan sinus membawa aliran vena dari otak dan bermuara di vena jugularis interna, kembali darah ke jantung. Vena serebral ini unik karena, tidak seperti pembuluh darah lainnya di dalam tubuh, mereka tidak memiliki katup untuk mencegah darah mengalir ke belakang dan tergantung pada kedua tekanan gravitasi dan darah untuk aliran.

e. Barier Darah Otak CNS tidak bisa diakses untuk banyak zat yang beredar dalam plasma darah (misalnya, pewarna, obat-obatan, dan antibiotik) karena penghalang darah-otak. Penghalang ini dibentuk oleh sel-sel endotel kapiler otak, dimana membentuk persimpangan ketat terus menerus, menciptakan penghalang untuk makromolekul dan banyak senyawa. Semua zat yang masuk CSF harus disaring melalui sel-sel endotel kapiler dan astrosit. Penghalang darah-otak memiliki fungsi pelindung, tetapi dapat diubah oleh trauma, edema serebral, dan hipoksemia serebral; ini memiliki implikasi dalam pengobatan dan pemilihan obat untuk gangguan CNS.

\section{f. Tulang Belakang}

Spinal cord merupakan kontinyu dengan medula, membentang dari hemisfer serebri dan berfungsi sebagai koneksi antara otak dan perifer. Panjang Sekitar $45 \mathrm{~cm}$ (18 inci) dan ketebalan sekitar jari, membentang dari foramen magnum di dasar tengkorak ke batas bawah vertebra lumbalis pertama, di mana ia meruncing ke sebuah band fibrosa yang disebut medullaris konus. Melanjutkan bawah ruang lumbar kedua adalah akar saraf yang melampaui konus, yang disebut cauda equina karena mereka menyerupai ekor kuda. Meninges mengelilingi sumsum tulang belakang.

Sebuah penampang dari sumsum tulang belakang terdapat gray matter dalam pola $\mathrm{H}$ di bagian tengah. Hal ini dikelilingi oleh white matter. Materi abu-abu mengandung badan sel neuron motoric volunter, preganglionik neuron motorik otonom, dan interneuron. White matter ascending mengandung akson sensorik dan descending saraf motorik. myelin yang mengelilingi serat ini memberi mereka penampilan putih.

Ascending saluran sensorik membawa informasi sensorik khusus untuk level yang lebih tinggi dari CNS. Informasi berasal dari reseptor khusus sensorik di kulit, otot, sendi, organ, dan pembuluh darah. Descending traktus motorik membawa impuls dari tingkat yang lebih tinggi ke syaraf motorik bawah. Bagian bawah syaraf motorik adalah tahap akhir dari impuls saraf sebelum stimulasi otot rangka. Neuron motor atas ini terletak di batang otak dan inti otak dan juga mempengaruhi gerakan otot rangka. Kerusakan pada neuron motor atas, kadang-kadang terlihat pada multiple sclerosis (MS), dapat menyebabkan kelemahan, atrofi, hiperrefleksia, atau kekejangan. 

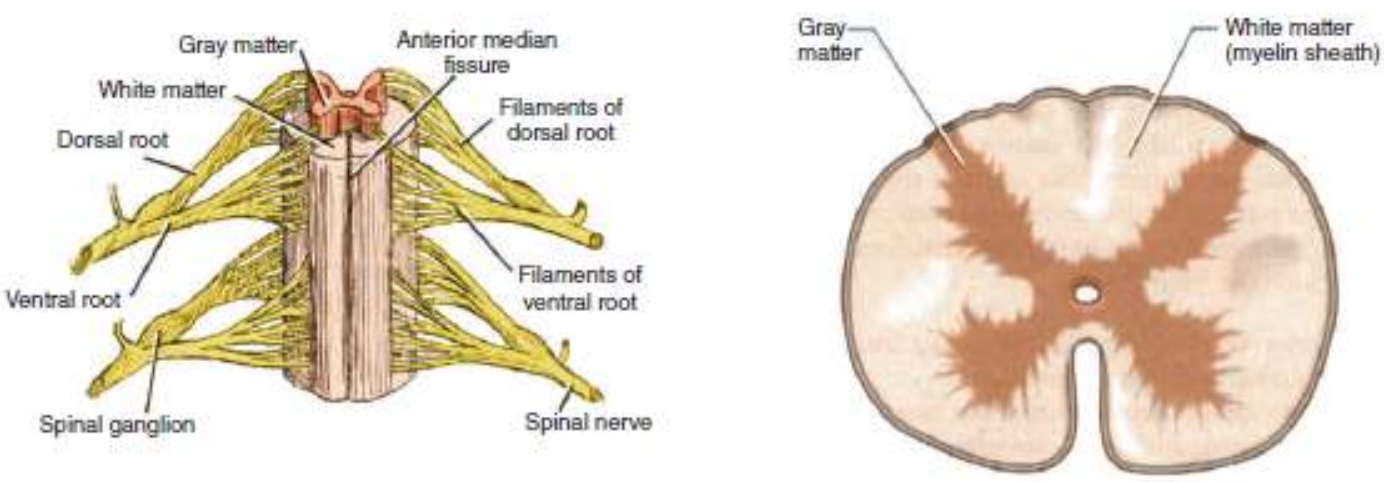

Culum Vertebra Tulang culum vertebral mengelilingi dan melindungi sumsum tulang belakang. erdiri dari 7 serviks, 12 toraks, dan 5 lumbar tulang belakang, dan juga sacrum (massa menyatu dari 5 vertebra), dan berakhir pada coccyx. araf berakar keluar dari kolom vertebra melalui foramina intervertebralis (celah). Vertebra dipisahkan oleh disk, kecuali untuk pertama dan kedua servikal, sakralis, dan tulang coccygeal. Setiap vertebra memiliki bodi padat ventral dan ruas dorsal atau lengkungan, yang bagian posterior tubuh. Lengkungan terdiri dari dua pedikel dan dua lamina penunjang tujuh proses. Tubuh vertebral, lengkungan, pedikel, lamina dan semua membungkus dan melindungi sumsum tulang belakang. 


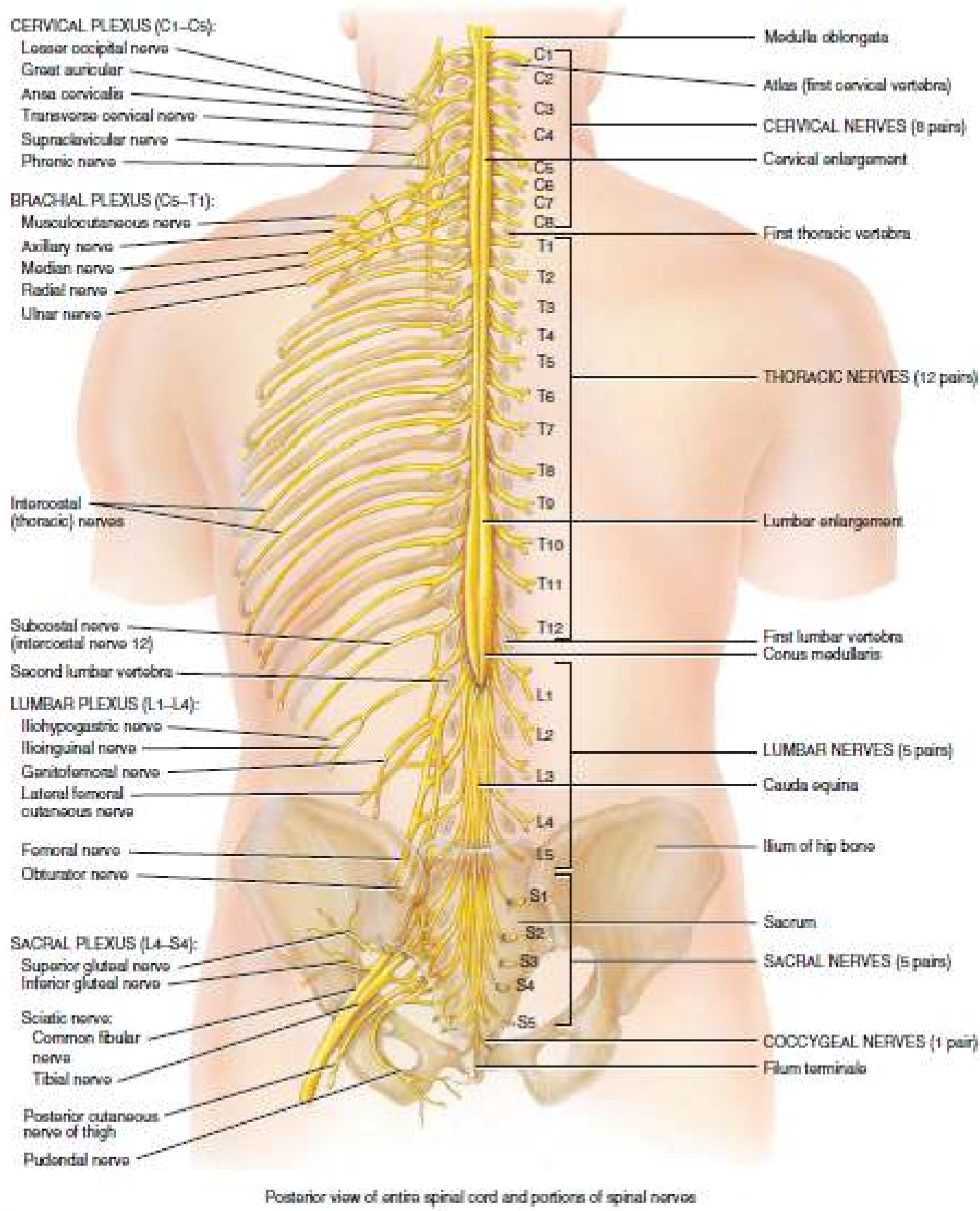

4. Sistem Saraf Perifer atau Peripheral Nervous System (PNS)

Sistem saraf perifer meliputi saraf kranial, saraf tulang belakang, dan sistem saraf otonom.

\section{a. Saraf cranial}

Dua belas pasang saraf kranial muncul dari permukaan bawah otak dan melewati celah di dasar tengkorak. Tiga seluruhnya sensorik (I, II, VIII), lima merupakan motorik (III, IV, VI, XI, dan XII), dan empat bercampur sensorik dan motorik (V, VII, IX, dan X). Saraf kranial diberi nomor dalam urutan tempat mereka timbul dari otak. Saraf kranial menginervasi kepala, leher, dan struktur indera khusus. 


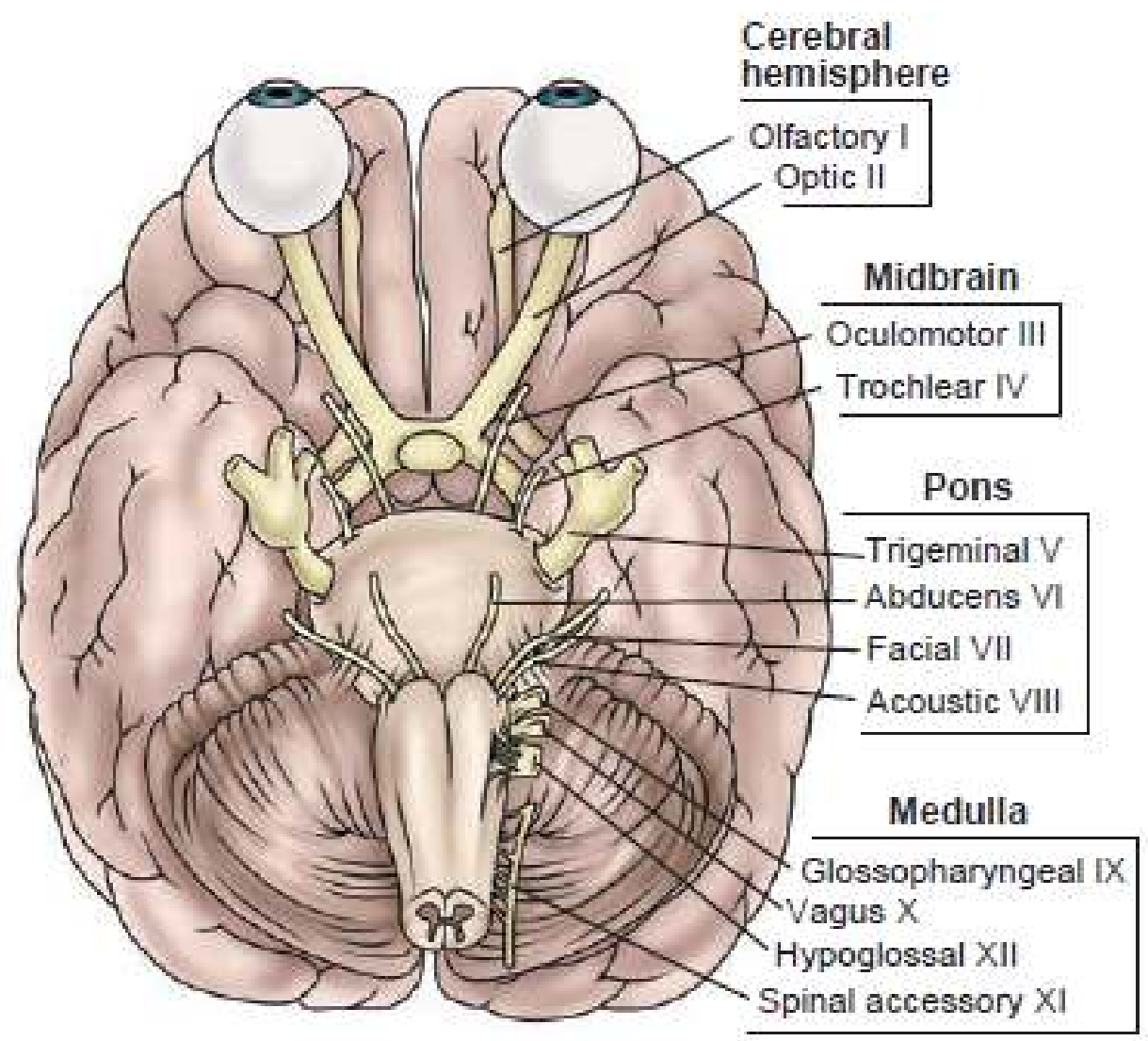

Figure 60-8 Diagram of the base of the brain showing entrance or exit of the cranial nerves. The right column shows the anatomic location of the connection of each cranial nerve to the central nervous system. 


\begin{tabular}{|c|c|c|}
\hline Cranial Nerve & Type & Function \\
\hline I (olfactory) & Sensory & Sense of smell \\
\hline II (optic) & Sensory & Visual acuity and visual fields \\
\hline III (oculomotor) & Motor & $\begin{array}{l}\text { Muscles that move the eye and } \\
\text { lid, pupillary constriction, } \\
\text { lens accommodation }\end{array}$ \\
\hline IV (trochlear) & Motor & Muscles that move the eye \\
\hline $\mathrm{V}$ (trigeminal) & Mixed & $\begin{array}{l}\text { Facial sensation, comeal reflex, } \\
\text { mastication }\end{array}$ \\
\hline VI (abducens) & Motor & Muscles that move the eye \\
\hline VII (facial) & Mixed & $\begin{array}{l}\text { Facial expression and muscle } \\
\text { movement, salivation and } \\
\text { tearing, taste, sensation in } \\
\text { the ear }\end{array}$ \\
\hline VIII (acoustic) & Sensory & Hearing and equilibrium \\
\hline IX (glossopharyngeal) & Mixed & $\begin{array}{l}\text { Taste, sensation in pharynx } \\
\text { and tongue, pharyngeal } \\
\text { muscles, swallowing }\end{array}$ \\
\hline $\mathrm{X}$ (vagus) & Mixed & $\begin{array}{l}\text { Muscles of pharynx, larynx, } \\
\text { and soft palate; sensation in } \\
\text { external ear, pharynx, } \\
\text { larynx, thoracic and } \\
\text { abdominal viscera; } \\
\text { parasympathetic innervation } \\
\text { of thoracic and abdominal } \\
\text { organs }\end{array}$ \\
\hline XI (spinal accessory) & Motor & $\begin{array}{l}\text { Sternocleidomastoid and } \\
\text { trapezius muscles }\end{array}$ \\
\hline XII (hypoglossal) & Motor & Movement of the tongue \\
\hline
\end{tabular}

\section{b. Saraf spinal}

Spinal cord terdiri dari 31 pasang saraf spinal: 8 servikal, 12 toraks, 5 lumbal, 5 sakralis, dan 1 coccygeal. Setiap saraf tulang belakang memiliki akar ventral dan akar dorsal. Akar dorsal merupakan sensorik dan mengirimkan impuls sensorik dari daerah tertentu dari tubuh yang dikenal sebagai dermatom ke ganglia dorsal horn. Serat sensorik bisa somatik, membawa informasi tentang rasa sakit, suhu, sentuhan, dan posisi akal (proprioception) dari tendon, sendi, dan permukaan tubuh; atau visceral, membawa informasi dari organ-organ internal. Akar ventral merupakan motorik dan mengirimkan impuls dari sumsum tulang belakang tubuh, dan serat ini juga baik somatik atau visceral. Serat visceral termasuk serat otonom yang mengendalikan otot-otot jantung dan sekresi kelenjar.

\section{Sistem saraf otonom}

ANS memiliki dua komponen semi-independen: simpatis dan parasimpatis. Kedua komponen berfungsi bersama-sama untuk mempertahankan homeostasis lingkungan internal tubuh. ANS yang bertanggung jawab untuk menjaga dan mengatur fungsi kelenjar dan otot-otot halus, dan mengkoordinasikan fungsi organ visceral. Sistem saraf simpatik bertanggung jawab untuk memulai mekanisme pelindung yang disebut respons fight-or-flight setiap kali tubuh terkena stres. Sistem 
parasimpatis mengirimkan impuls ke organ viseral dan bertanggung jawab untuk fungsi-fungsi yang tidak di bawah kendali kesadaran, yang disebut istirahat dan perbaikan atau " General housekeeping."

Pada sistem saraf otonom mempersarafi sebagian besar organ tubuh. Meskipun biasanya dianggap sebagai bagian dari sistem saraf perifer, sistem ini diatur oleh pusat di sumsum tulang belakang, batang otak, dan hipotalamus. Sistem saraf otonom memiliki dua neuron dalam serangkaian membentang antara pusat-pusat di CNS dan organ yang diinervasi. Neuron pertama, neuron preganglionik, ini terletak di otak atau sumsum tulang belakang, dan akson yang meluas ke ganglia otonom. Di sana, ia sinapsis dengan neuron kedua, neuron postganglionik, terletak di ganglia otonom, dan akson yang sinapsis dengan jaringan target dan mempersarafi organ efektor. Efek peraturan diberikan bukan pada sel-sel individual tetapi pada hamparan besar jaringan dan pada seluruh organ. Tanggapan yang ditimbulkan tidak terjadi secara instan, tetapi setelah periode jeda. Tanggapan ini dipertahankan jauh lebih lama daripada respon neurogenik lain untuk memastikan efisiensi fungsional maksimal pada bagian organ reseptor, seperti pembuluh darah.

Hipotalamus merupakan pusat subkortikal utama untuk pengaturan kegiatan visceral dan somatik, melayani peranan rangsang inhibitor dalam sistem saraf otonom. Hipotalamus memiliki koneksi yang menghubungkan sistem otonom dengan thalamus, korteks, aparatus olfaktori, dan kelenjar pituitari. Terletak di sini merupakan mekanisme kontrol reaksi visceral dan somatik yang awalnya penting untuk pertahanan atau serangan dan berhubungan dengan kondisi emosional (misalnya, takut, marah, gelisah); untuk kontrol proses metabolisme, termasuk lemak, karbohidrat, dan metabolisme air; untuk pengaturan suhu tubuh, tekanan arteri, dan semua kegiatan otot dan kelenjar saluran pencernaan; untuk mengendalikan fungsi genital; dan untuk siklus tidur.

Pada sistem saraf otonom terpisah menjadi divisi simpatis dan parasimpatis anatomis dan fungsional yang berbeda. Sebagian besar jaringan dan organ-organ di bawah kontrol otonom dipersarafi oleh kedua sistem. Sebagai contoh, divisi parasimpatis menyebabkan kontraksi (stimulasi) dari otot-otot kandung kemih dan adanya penurunan (inhibisi) denyut jantung, sedangkan pembagian simpatis menghasilkan relaksasi (inhibisi) dari kandung kemih dan peningkatan (stimulasi) di tingkat dan kekuatan detak jantung. Tabel berikut membandingkan simpatik dan efek parasimpatis pada sistem yang berbeda dari tubuh. 


\begin{tabular}{|c|c|c|}
\hline $\begin{array}{l}\text { Structure or } \\
\text { Activity }\end{array}$ & $\begin{array}{l}\text { Parasympathetic } \\
\text { Effects }\end{array}$ & $\begin{array}{l}\text { Sympathetic } \\
\text { Effects }\end{array}$ \\
\hline $\begin{array}{l}\text { Pupil of the Eye } \\
\text { Circulatory System }\end{array}$ & Canstricted & Dilatied \\
\hline $\begin{array}{l}\text { Rate and force of heartbeat } \\
\text { Blood wesects }\end{array}$ & Derreased & Increaved \\
\hline In heart muscle & Canstricted & Dilated \\
\hline In skeletal muscle & + & Dilated \\
\hline $\begin{array}{l}\text { In abdominal viscena } \\
\text { and the stin }\end{array}$ & + & Constricted \\
\hline Blocod pressure & Decreased & Incressed \\
\hline $\begin{array}{l}\text { Respiratory System } \\
\text { Bnsnchioles } \\
\text { Rate of bruathing }\end{array}$ & $\begin{array}{l}\text { Constricted } \\
\text { Decreased }\end{array}$ & $\begin{array}{l}\text { Dilated } \\
\text { Increased }\end{array}$ \\
\hline $\begin{array}{l}\text { Digestive System } \\
\text { Peristaltic mowements of } \\
\text { digestive tube }\end{array}$ & Increased & Decreased \\
\hline $\begin{array}{l}\text { Muscular ephincters of } \\
\text { digestive tube }\end{array}$ & Relaxed & Contracted \\
\hline Secretion of salivary glands & Thin, watery saliva & Thick, viscid saliva \\
\hline $\begin{array}{l}\text { Secretions of stomach, } \\
\text { intestine, and pancreser }\end{array}$ & Increased & $\cdot$ \\
\hline $\begin{array}{l}\text { Conversion of liver } \\
\text { glycogen to glucuse }\end{array}$ & $\bullet$ & Increased \\
\hline \multicolumn{3}{|l|}{$\begin{array}{l}\text { Genitourinary System } \\
\text { Urinary bladder }\end{array}$} \\
\hline Muscle walls & Cantracted & Relaxed \\
\hline Sphincters & Relanxed & Contracted \\
\hline Muscles of the uterus & Relaxed; vanäble & $\begin{array}{l}\text { Contracted under } \\
\text { some conditions; } \\
\text { varies with } \\
\text { menstrual eyde } \\
\text { and pregnancy }\end{array}$ \\
\hline $\begin{array}{l}\text { Blocid vessels of external } \\
\text { genitalia }\end{array}$ & Diluted & 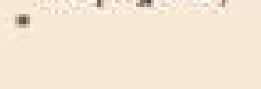 \\
\hline Integumentary System & & \\
\hline Secretion of sweat & - & Increesed \\
\hline Pilomoxes inascles & * & $\begin{array}{l}\text { Cocitracted } \\
\text { (gocose-flesh) }\end{array}$ \\
\hline Adrenal Medulla & - & $\begin{array}{l}\text { Secretion of } \\
\text { epinephrine and } \\
\text { norepinephrias }\end{array}$ \\
\hline
\end{tabular}

\footnotetext{
Na diroct elfoct.

From Hickey, J. (2009). Clininal pranke of neurobgical and nemsenged mume (6th ed). Philadelphir Lippincott Willians \&. Wilkins.
}

Sympathetic Nervous System, Divisi simpatik dari pada sistem saraf otonom terkenal karena perannya dalam " fight-or-flight " respon tubuh. Di bawah tekanan dari penyebab fisik atau emosional, impuls simpatik meningkat sangat. Akibatnya, bronkiolus membesar untuk pertukaran gas lebih mudah; kontraksi jantung lebih kuat dan lebih cepat; arteri ke jantung dan otot-otot membesar, membawa lebih banyak darah ke organ-organ ini; pembuluh darah perifer mengerut, membuat kulit terasa dingin tapi darah ke organ-organ penting; pupil membesar; hati mensekresi glukosa untuk energi cepat; peristalsis memperlambat; rambut berdiri di akhir; dan meningkatkan keringat. Neurotransmitter simpatik utama adalah norepinefrin 
(noradrenalin). Sebuah debit simpatik merupakan sama seperti jika tubuh telah diberikan injeksi adrenalin-karenanya, adrenergik Istilah ini sering digunakan untuk merujuk pada pembagian hal ini.

Sistem saraf Parasimpatis, sistem saraf Parasimpatis berfungsi sebagai pengendali dominan untuk efektor sebagian besar visceral; neurotransmitter utama adalah asetilkolin. Pada saat tenang, kondisi nonstressful, impuls dari serat parasimpatis (kolinergik) mendominasi. Serat dari sistem parasimpatis berada dalam dua bagian, satu di batang otak dan yang lain dari segmen tulang belakang bawah L2. Karena lokasi serat ini, sistem parasimpatis disebut sebagai divisi craniosacral, berbeda dari torakolumbalis (simpatik) pembagian pada sistem saraf otonom. Saraf parasimpatis berasal dari midbrain dan medulla oblongata. Serat dari sel-sel di midbrain perjalanan dengan oculomotor saraf ketiga ganglia siliaris, di mana serat postganglionik dari divisi ini bergabung dengan yang dari sistem simpatik, menciptakan dikontrol oposisi, dengan keseimbangan dipertahankan antara dua setiap saat. 


\section{DAFTAR PUSTAKA}

Daniels, R., \& Nicoll, L. (2012). Contemporary Medical Surgical Nursing (2nd ed.). Clifton Park: Delmar, Cengage Learning.

Smeltzer, S. C., Hinkle, J. L., Bare, B. G., \& Cheever, K. H. (2010). Brunner \& Suddarth's textbook of medical-surgical nursing (12th ed., p. 1828). Philadelphia: Lippincott Williams \& Wilkins.

Timby, B. K., \& Smith, N. E. (2010). Introductory Medical Surgical Nursing (10th ed.). 2010: Lippincott Williams \& Wilkins.

Tortora, G. J., \& Derrickson, B. (2014). Principles Of Anatomy and Phisiology (14th ed., p. 400). Hoboken USA: Wiley.

White, L., Duncan, G., \& Baumle, W. (2013). Medical-Surgical Nursing: An Integrated Approach (3rd ed.). Clifton Park, USA: Delmar, Cengage Learning.

Syaifuddin,H.2002. Anatomi fisiologi berbasis kompetensi untuk keperawatan dan kebidanan.Jakarta:Penerbi EKG

Syaifuddin,Haji.2006. Anatomi fisiologis mahasiswa keperawatan. Jakarta Penerbit:EKG

Syaifuddin. 2009. Fisiologi tubuh manusia untuk mahasiswa keperawatan. Jakarta Penerbit: Salemba Medika.

Muttaqin,Arif.2009. Asuhan keperawatan klien dengan gangguan sistem kardiovaskuler. . Jakarta. Penerbit: Salemba Medika 